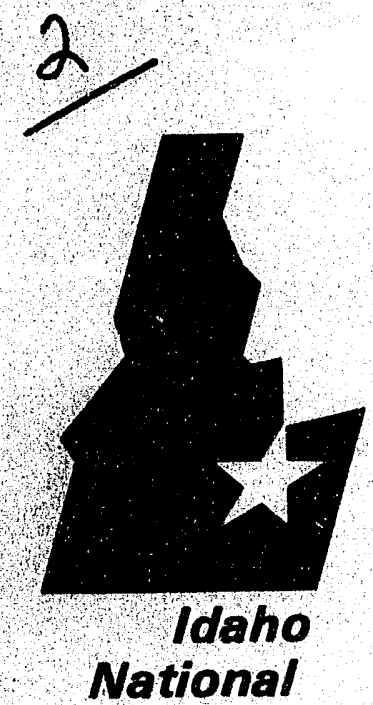

Engineering

Laboratory

Managed

by the U.S.

Department

of Energy
EGG-WTD-10443

October 1992

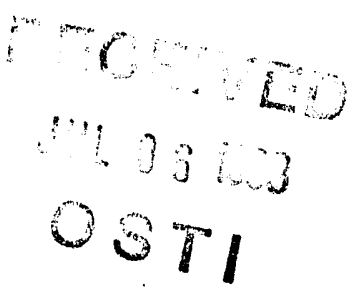

\title{
Waste Management Facilities Cost Information Report
}

\section{Fred Folzollahi \\ David Shropshire}

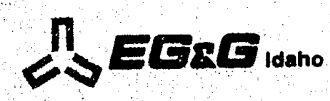

Work performed under DOE Contract

No. DE-AC07-761D01570 
This document contains new concepts or the author(s) interpretation of new calculations and/or measurements; accordingly, EG\&G Idaho, Inc. is required by the United States Government to include the following disclaimer:

\section{DISCLAIMER}

This report was prepared as an accsunt of work sponsored by an agency of the United States Government. Neither the United States Government nor any agency thereot, nor any of their employees. makes any warranty, express or implied, or assumes any legal liability or responsibility for the accuracy, completeness. or usefuiness of any information, apparatus, product or process disclosed. or represents that its use would not infringe privately owned rights. References herein to any specific commercial product. process. or service by trade name, trademark. manufacturer, or otherwise, does not necessarily constitute or imply its endorsement, recommendation. or favoring by the United States Government or any agency thereof. The views and opinions of authors expressed herein do not necessarily state or reflect those of the United States Government or any agency thereot. 


\title{
Waste Management Facilities Cost Information Report
}

\author{
Fred Feizollahi
}

David Shropshire

Published October 1992

Idaho National Engineering Laboratory

EG\&G Idaho, Inc.

Idaho Falls, Idaho 83415

Prepared for the

U.S. Department of Energy

Idaho Operations Office

Under DOE Idaho Fleld Office

Contract DE-AC07-76ID01570

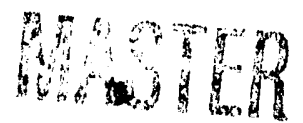

DISTRIEUTION OF THIS DOCUMENT IS UNLIMITED of 


\section{Waste Management Facilities Cost Information Report}

EGG-WM-10443

Prepared by:

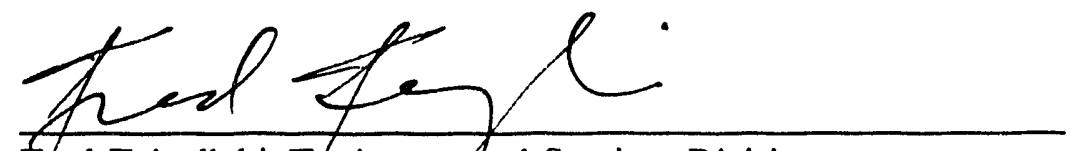

Fred Feizollahi, Ehvironmental Services Division,

Morrison Knudseh Corparation

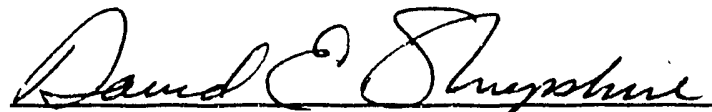

David Shropshire, Complex Configuration Technica! Support, EG\&G Idaho, Inc.

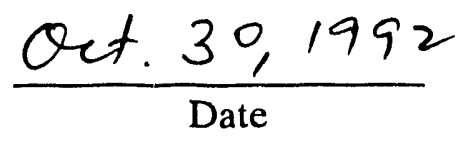

$\frac{\text { Oct.3e, } 1992}{\text { Date }}$

Reviewed by:

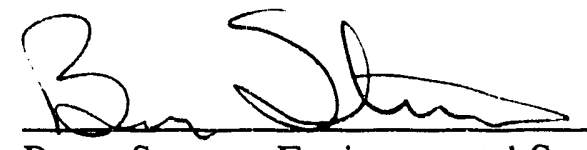

Bruce Stevens, Environmental Services Division, Morrison Knudsen Corporation

Reviewed and Approved by:

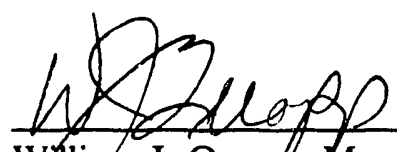

Wŕliam J. Quapp, Manager Private Sector Participation Initiative, EG\&G Idaho, Inc.
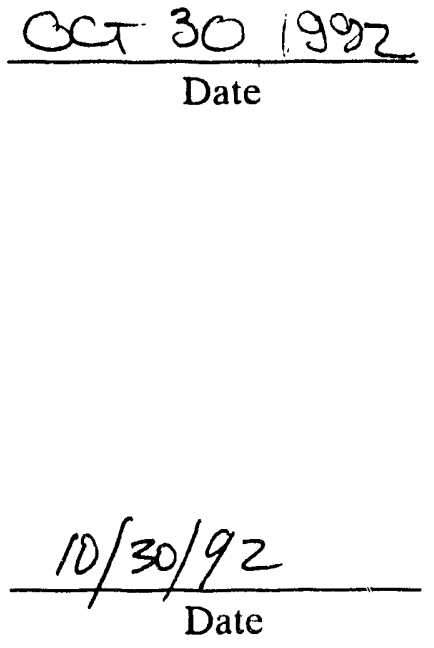


\section{ABSTRACT}

The Waste Management Facility Cost Information (WMFCI) Report, commissioned by the U.S. Department of Energy (DOE), develops planning life-cycle cost (PLCC) estimates for treatment, storage, and disposal facilities. This report contains PLCC estimates versus capacity for 26 different facility cost modules. A procedure to guide DOE and its contractor personnel in the use of estimating data is also provided. Estimates in the report apply to five distinctive waste streams: low-level waste, low-level mixed waste alpha contaminated low-level waste, alpha contaminated low-level mixed waste, and transuranic waste. The report addresses five different treatment types: incineration, metal/melting and recovery, shredder/compaction, solidification, and vitrification. Data in this report allow the user to develop PLCC estimates for various waste management options. 


\section{ACKNOWLEDGEMENTS}

The authors would like to acknowledge the efforts of those who contributed to this report: William Quapp of EG\&G Idaho, Inc.; Clyde Ward of Westinghouse Savannah River; Rick Barlow, David Bean, David Burton, Narayanan Doraswamy, Joe Foldyna, Hilary Lewis, Lisa Penaska, Greg Richardson, Bruce Stevens, Ben Teheranian and Gary Wells of Environmental Services Division, Morrison Knudsen Corporation; the editor Vida Rose of Morrison Knudsen Corporation. 


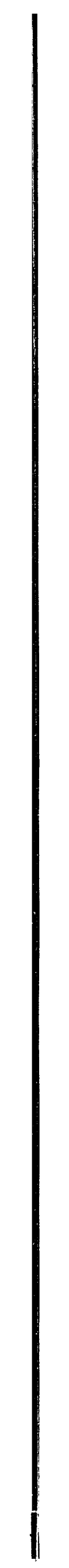


3.4 Cost Summaries

4. CONTAINER OPEN, DUMP, AND SORT FACILITY (COST MODULES

CL AND CA)

$4.1 \quad$ Basic Information $\ldots \ldots \ldots \ldots \ldots \ldots \ldots \ldots \ldots \ldots \ldots \ldots \ldots \ldots$

4.2 Technical Basis and Assumptions $\ldots \ldots \ldots \ldots \ldots \ldots \ldots \ldots \ldots \ldots$

4.2.1 Functional and Operational Description $\ldots \ldots \ldots \ldots \ldots \ldots \ldots \ldots$

4.2.2 Facility Integration $\ldots \ldots \ldots \ldots \ldots \ldots \ldots \ldots \ldots \ldots \ldots \ldots \ldots \ldots$

4.3 Cost Bases, Assumptions, and Assessments $\ldots \ldots \ldots \ldots \ldots \ldots$

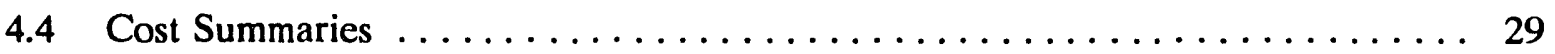

5. INCINERATION FACILITY (COST MODULES DL AND DA) $\ldots \ldots \ldots \ldots$

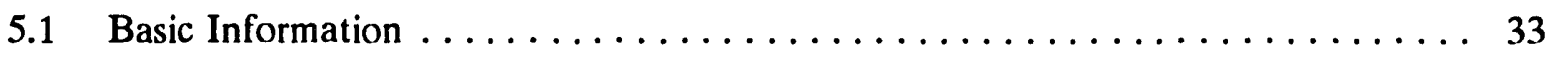

5.2 Technical Bases and Assumptions $\ldots \ldots \ldots \ldots \ldots \ldots \ldots \ldots \ldots \ldots \ldots \ldots \ldots \ldots$

5.2.1 Functional and Operational Description .............. 33

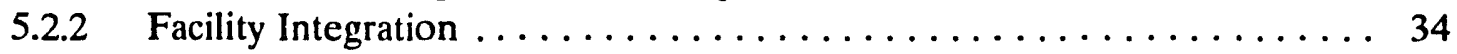

5.3 Cost Bases, Assumptions, and Assessments ................ 34

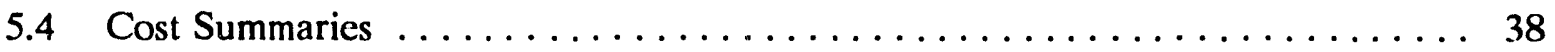

6. METAL MELTING FACILITY (COST MODULES EA AND EL) . . . . . . . 42

6.1 Basic Information $\ldots \ldots \ldots \ldots \ldots \ldots \ldots \ldots \ldots \ldots \ldots \ldots \ldots \ldots$

6.2 Technical Bases and Assumptions $\ldots \ldots \ldots \ldots \ldots \ldots \ldots \ldots \ldots \ldots \ldots \ldots$

6.2.1 Functional and Operational Description .............. 42

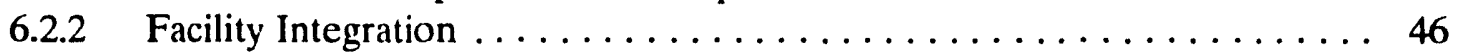

6.3 Cost Bases, Assumptions, and Assessments $\ldots \ldots \ldots \ldots \ldots \ldots$

6.4 Cost Summaries $\ldots \ldots \ldots \ldots \ldots \ldots \ldots \ldots \ldots \ldots \ldots \ldots \ldots \ldots \ldots$

7. SHREDDING/COMPACTION FACILITY (COST MODULES FA AND FL) . . . . 53

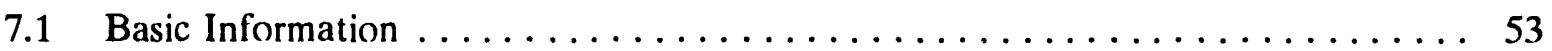

7.2 Trchnical Basis and Assumptions $\ldots \ldots \ldots \ldots \ldots \ldots \ldots \ldots \ldots \ldots \ldots \ldots \ldots \ldots$ 


\section{CONTENTS}

ABSTRACT $\ldots \ldots \ldots \ldots \ldots \ldots \ldots \ldots \ldots \ldots \ldots \ldots \ldots \ldots \ldots \ldots \ldots \ldots \ldots \ldots$

ACKNOWLEDGEMENTS $\ldots \ldots \ldots \ldots \ldots \ldots \ldots \ldots \ldots \ldots \ldots \ldots \ldots \ldots \ldots$

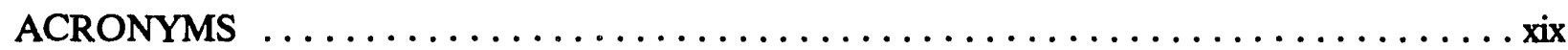

1. INTRODUCTION AND SUMMARY $\ldots \ldots \ldots \ldots \ldots \ldots \ldots \ldots \ldots \ldots \ldots \ldots \ldots$

$1.1 \quad$ Background $\ldots \ldots \ldots \ldots \ldots \ldots \ldots \ldots \ldots \ldots \ldots \ldots \ldots \ldots \ldots$

1.2 "WMFCI" Task Participants $\ldots \ldots \ldots \ldots \ldots \ldots \ldots \ldots \ldots \ldots \ldots \ldots \ldots$

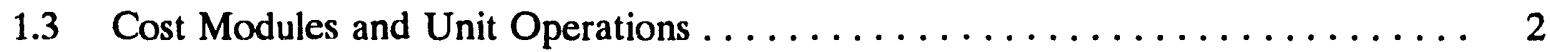

1.4 Facility Cost Estimating Methodology $\ldots \ldots \ldots \ldots \ldots \ldots \ldots \ldots \ldots \ldots$

1.5 Waste Management Scenario Costing Procedure $\ldots \ldots \ldots \ldots \ldots \ldots \ldots$

1.6 Cost Assessment Activities $\ldots \ldots \ldots \ldots \ldots \ldots \ldots \ldots \ldots \ldots \ldots \ldots \ldots$

1.7 Report Organization $\ldots \ldots \ldots \ldots \ldots \ldots \ldots \ldots \ldots \ldots \ldots \ldots \ldots \ldots \ldots$

$1.8 \quad$ Limitations $\ldots \ldots \ldots \ldots \ldots \ldots \ldots \ldots \ldots \ldots \ldots \ldots \ldots \ldots \ldots \ldots$

2. TREATMENT FRONT-END SUPPORT FACILITY (COST MODULE A) $\ldots \ldots \ldots 14$

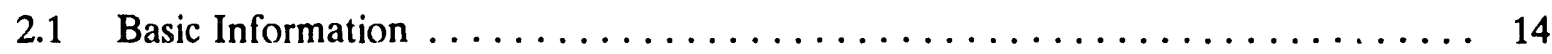

2.2 Technical Basis and Requirements $\ldots \ldots \ldots \ldots \ldots \ldots \ldots \ldots \ldots$

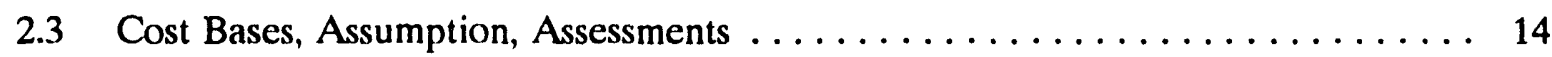

2.4 Cost Summaries $\ldots \ldots \ldots \ldots \ldots \ldots \ldots \ldots \ldots \ldots \ldots \ldots \ldots \ldots$

3. TREATMENT RECEIVING AND INSPECTION FACILITY (COST

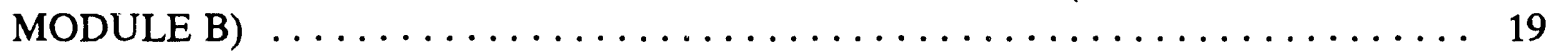

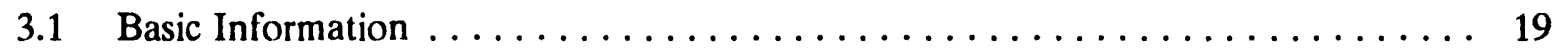

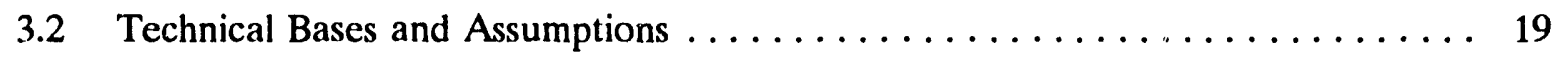

3.2.1 Functional and Operational Description $\ldots \ldots \ldots \ldots \ldots \ldots \ldots$

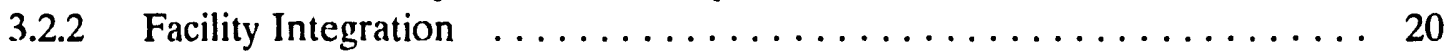

3.3 Cost Bases, Assumptions, and Assessments $\ldots \ldots \ldots \ldots \ldots \ldots \ldots \ldots \ldots \ldots \ldots \ldots \ldots$ 


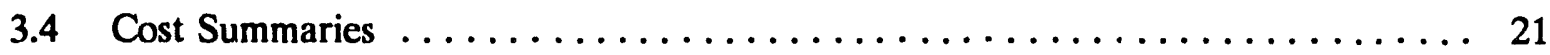

4. CONTAINER OPEN, DUMP, AND SORT FACILITY (COST MODULES

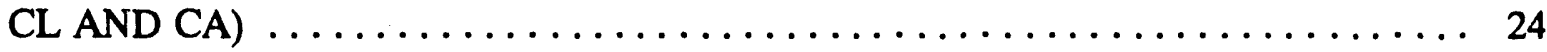

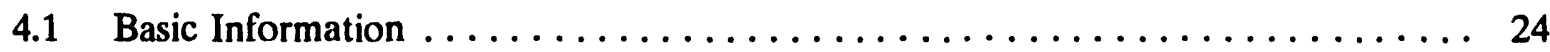

4.2 Technical Basis and Assumptions $\ldots \ldots \ldots \ldots \ldots \ldots \ldots \ldots \ldots \ldots \ldots \ldots$

4.2.1 Functional and Operational Description $\ldots \ldots \ldots \ldots \ldots \ldots \ldots \ldots \ldots$

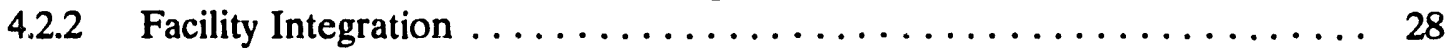

4.3 Cost Bases, Assumptions, and Assessments $\ldots \ldots \ldots \ldots \ldots \ldots \ldots \ldots \ldots$

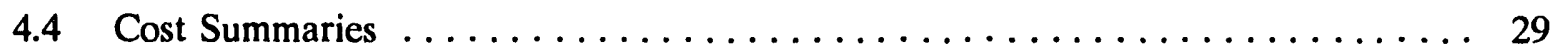

5. INCINERATION FACILITY (COST MODULES DL AND DA) $\ldots \ldots \ldots \ldots$

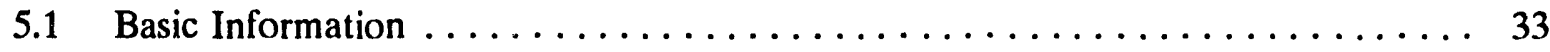

5.2 Technical Bases and Assumptions $\ldots \ldots \ldots \ldots \ldots \ldots \ldots \ldots \ldots \ldots \ldots \ldots \ldots \ldots \ldots$

5.2.1 Functional and Operational Description $\ldots \ldots \ldots \ldots \ldots \ldots \ldots \ldots$

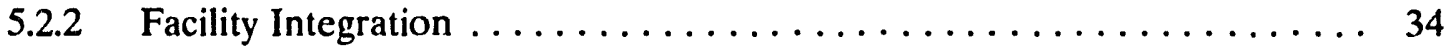

5.3 Cost Bases, Assumptions, and Assessments $\ldots \ldots \ldots \ldots \ldots \ldots \ldots \ldots \ldots$

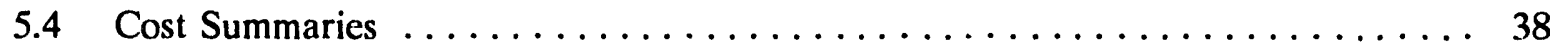

6. METAL MELTING FACILITY (COST MODULES EA AND EL) . . . . . . . 42

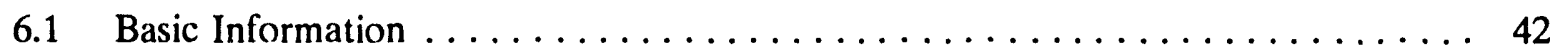

6.2 Technical Bases and Assumptions $\ldots \ldots \ldots \ldots \ldots \ldots \ldots \ldots \ldots \ldots \ldots \ldots \ldots \ldots$

6.2.1 Functional and Operational Description ................ 42

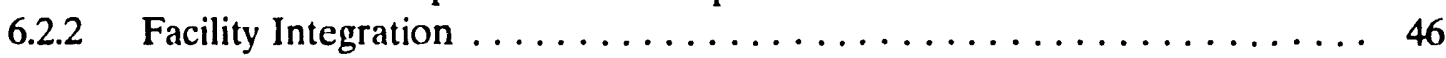

6.3 Cost Bases, Assumptions, and Assessments $\ldots \ldots \ldots \ldots \ldots \ldots \ldots \ldots \ldots$

6.4 Cost Summaries $\ldots \ldots \ldots \ldots \ldots \ldots \ldots \ldots \ldots \ldots \ldots \ldots \ldots \ldots \ldots \ldots$

7. SHREDDING/COMPACTION FACILITY (COST MODULES FA AND FL) . . . 53

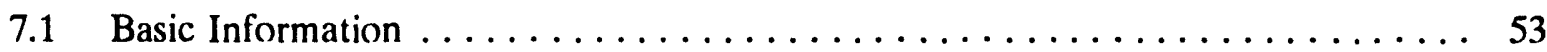

7.2 Technical Basis and Assumptions $\ldots \ldots \ldots \ldots \ldots \ldots \ldots \ldots \ldots \ldots \ldots \ldots \ldots \ldots \ldots$ 
7.2.1 Functional and Operational Description $\ldots \ldots \ldots \ldots \ldots \ldots \ldots \ldots \ldots$

7.2.2 Facility Integration $\ldots \ldots \ldots \ldots \ldots \ldots \ldots \ldots \ldots \ldots \ldots \ldots \ldots$

7.3 Cost Bases, Assumptions, and Assessments $\ldots \ldots \ldots \ldots \ldots \ldots \ldots$

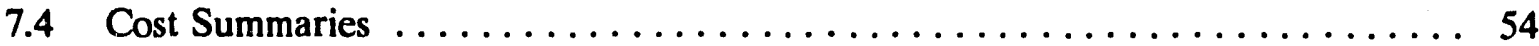

8. SOLIDIFICATION FACILITY (COST MODULES GA AND GL) $\ldots \ldots \ldots \ldots 2$

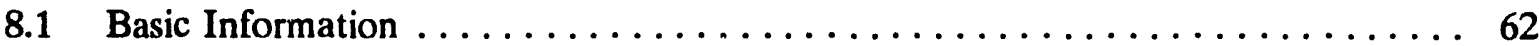

8.2 Technical Bases and Assumptions $\ldots \ldots \ldots \ldots \ldots \ldots \ldots \ldots \ldots \ldots \ldots \ldots \ldots$

8.2.1 Functional and Operational Description $\ldots \ldots \ldots \ldots \ldots \ldots \ldots \ldots$

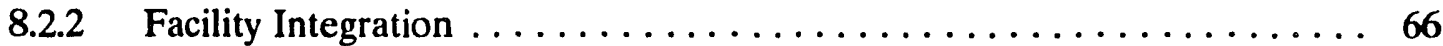

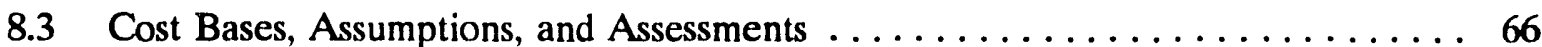

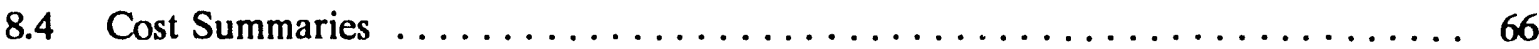

9. VITRIFICATION FACILITY (COST MODULES HL AND HA) $\ldots \ldots \ldots \ldots \ldots$

9.1 Basic Information $\ldots \ldots \ldots \ldots \ldots \ldots \ldots \ldots \ldots \ldots \ldots \ldots \ldots \ldots \ldots$

9.2 Technical Bases and Assumptions $\ldots \ldots \ldots \ldots \ldots \ldots \ldots \ldots \ldots \ldots \ldots \ldots$

9.2.1 Functional and Operational Description ............... 71

9.2.2 Facility Integration $\ldots \ldots \ldots \ldots \ldots \ldots \ldots \ldots \ldots \ldots \ldots \ldots \ldots \ldots$

9.3 Cost Bases, Assumptions, and Assessments $\ldots \ldots \ldots \ldots \ldots \ldots \ldots \ldots \ldots$

9.4 Cost Summaries $\ldots \ldots \ldots \ldots \ldots \ldots \ldots \ldots \ldots \ldots \ldots \ldots \ldots \ldots \ldots$

10. CERTIFICATION/SHIPPING FACILITY (COST MODULE I) $\ldots \ldots \ldots \ldots 1$

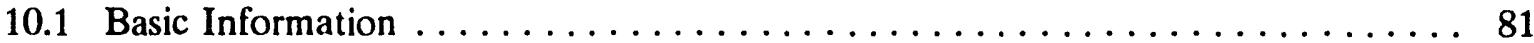

10.2 Technical Bases and Assumptions $\ldots \ldots \ldots \ldots \ldots \ldots \ldots \ldots \ldots \ldots \ldots$

10.2.1 Functional and Operational Description .............. 81

10.2.2 Facility Integration $\ldots \ldots \ldots \ldots \ldots \ldots \ldots \ldots \ldots \ldots \ldots \ldots \ldots$

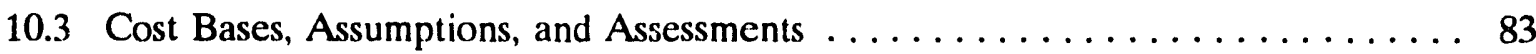

10.4 Cost Summaries $\ldots \ldots \ldots \ldots \ldots \ldots \ldots \ldots \ldots \ldots \ldots \ldots \ldots \ldots \ldots \ldots$ 
11. TREATMENT MAINTENANCE FACILITY (COST MODULES JL AND JA) . . . 86

11.1 Basic Information $\ldots \ldots \ldots \ldots \ldots \ldots \ldots \ldots \ldots \ldots \ldots \ldots \ldots \ldots \ldots \ldots \ldots \ldots$

11.2 Technical Bases and Assumptions $\ldots \ldots \ldots \ldots \ldots \ldots \ldots \ldots \ldots \ldots$

11.3 Cost Bases, Assumptions, and Assessments $\ldots \ldots \ldots \ldots \ldots \ldots$

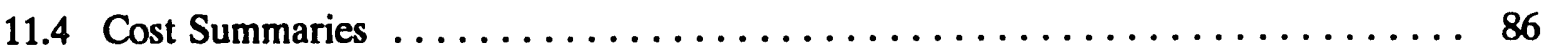

12. STORAGE FRONT-END/BACK-END SUPPORT FACILITY (COST

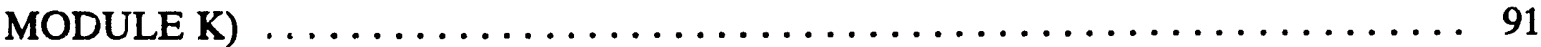

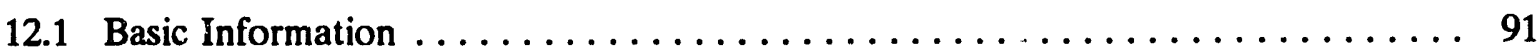

12.2 Technical Basis and Requirements $\ldots \ldots \ldots \ldots \ldots \ldots \ldots \ldots \ldots \ldots \ldots \ldots \ldots \ldots \ldots$

12.2.1 Functional and Operational Description $\ldots \ldots \ldots \ldots \ldots \ldots \ldots \ldots \ldots$

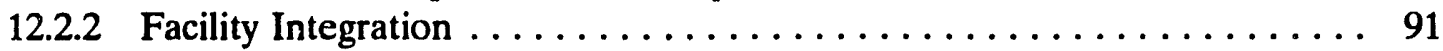

12.3 Cost Bases, Assumptions, and Assessments $\ldots \ldots \ldots \ldots \ldots \ldots \ldots \ldots \ldots$

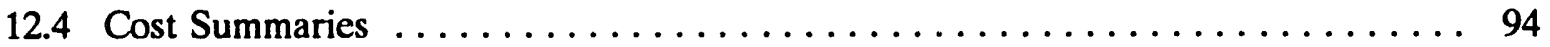

13. LLW/LLMW, ALPHA-LLW/LLMW, AND TRUW STORAGE

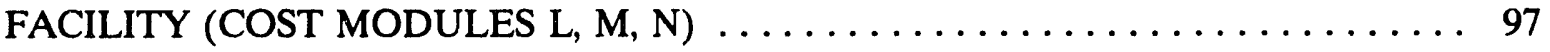

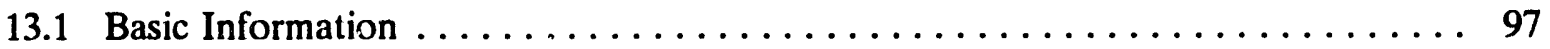

13.2 Technical Bases and Assumptions $\ldots \ldots \ldots \ldots \ldots \ldots \ldots \ldots \ldots \ldots \ldots$

13.2.1 Functional and Operational Description $\ldots \ldots \ldots \ldots \ldots \ldots \ldots \ldots$

13.2.2 Facilities Integration $\ldots \ldots \ldots \ldots \ldots \ldots \ldots \ldots \ldots \ldots \ldots \ldots \ldots \ldots$

13.3 Cost Bases, Assumptions, and Assessments $\ldots \ldots \ldots \ldots \ldots \ldots \ldots$

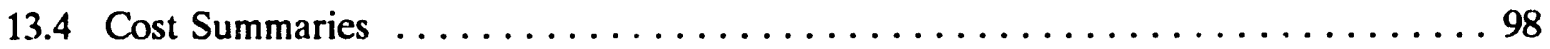

14. DISPOSAL FRONT-END SUPPORT FACILITY (COST MODULE O) $\ldots \ldots \ldots 101$

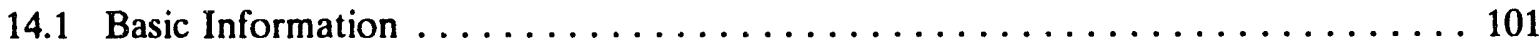

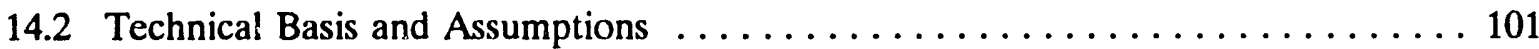

14.2.1 Functional and Operational Description $\ldots \ldots \ldots \ldots \ldots \ldots \ldots \ldots \ldots \ldots$

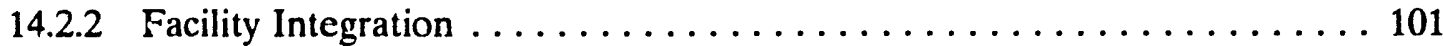




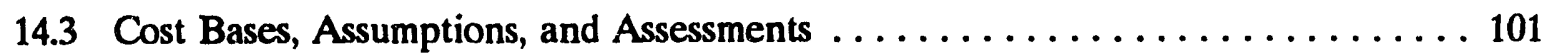

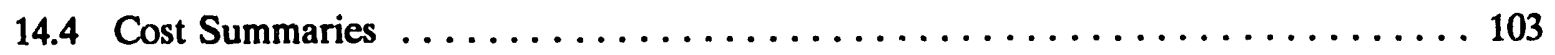

15. ENGINEERED DISPOSAL FACILITIES (COST MODUL ES P AND Q) $\ldots \ldots \ldots 106$

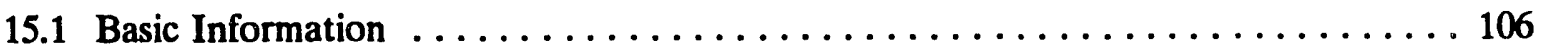

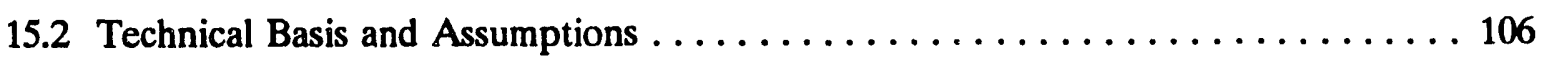

15.2.1 Functional and Operational Description $\ldots \ldots \ldots \ldots \ldots \ldots \ldots \ldots \ldots$

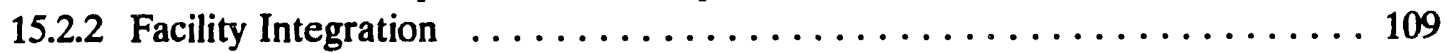

15.3 Cost Bases, Assumptions, and Assessments $\ldots \ldots \ldots \ldots \ldots \ldots \ldots \ldots \ldots \ldots \ldots$

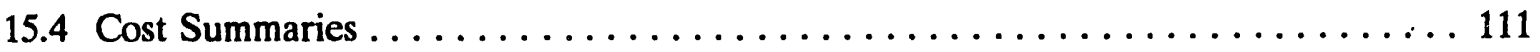

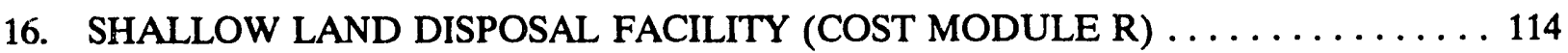

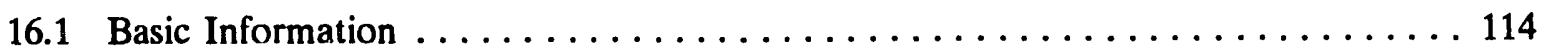

16.2 Technical Bases and Assumptions . . . . . . . . . . . . . 114

16.3 Cost Bases, Assumptions, and Assessments $\ldots \ldots \ldots \ldots \ldots \ldots \ldots \ldots \ldots \ldots$

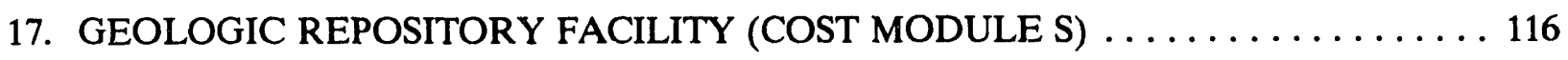

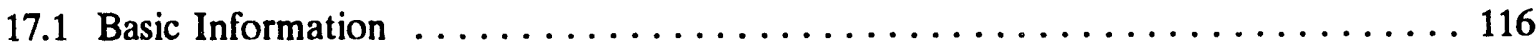

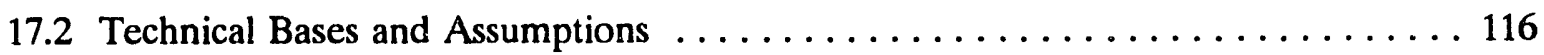

17.3 Cost Bases, Assumptions, and Assessments $\ldots \ldots \ldots \ldots \ldots \ldots \ldots \ldots \ldots$

18. SCENARIO COSTING PROCEDURE $\ldots \ldots \ldots \ldots \ldots \ldots \ldots \ldots \ldots \ldots \ldots$

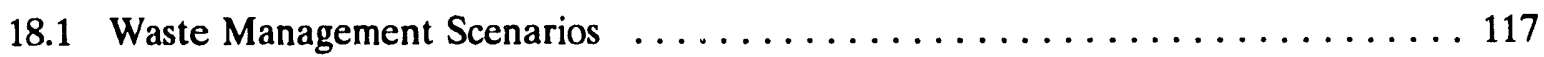

18.2 Cost Modules and Unit Operations $\ldots \ldots \ldots \ldots \ldots \ldots \ldots \ldots \ldots \ldots \ldots \ldots$

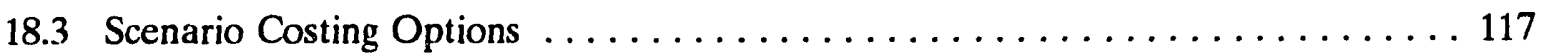

18.4 Information Required to Cost a Scenario $\ldots \ldots \ldots \ldots \ldots \ldots \ldots \ldots \ldots \ldots$

18.5 Scenario Costing Procedure $\ldots \ldots \ldots \ldots \ldots \ldots \ldots \ldots \ldots \ldots \ldots \ldots \ldots \ldots \ldots \ldots \ldots$

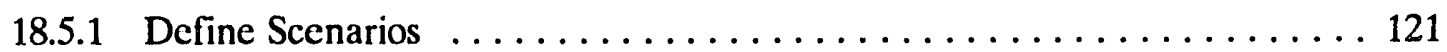

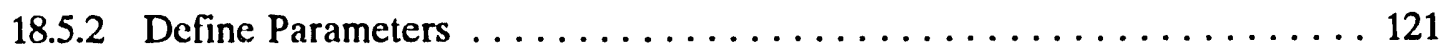




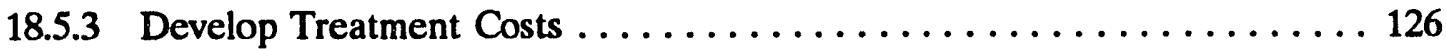

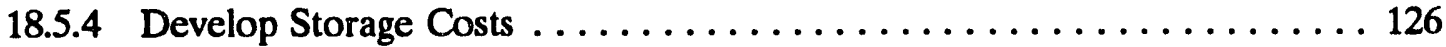

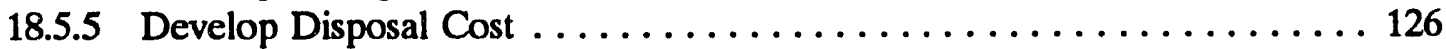

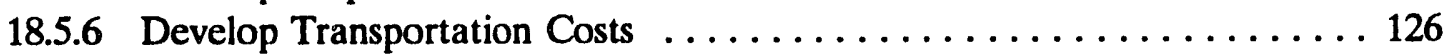

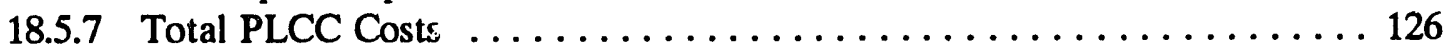

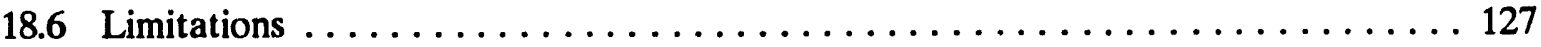

19. REFERENCES . . . . . . . . . . . . . . . . . . . . . . . . 129

Appendix A-Methodology, Assumptions and Bases $\ldots \ldots \ldots \ldots \ldots \ldots \ldots \ldots \ldots \ldots$

Appendix B-Scenario Costing Worksheet $\ldots \ldots \ldots \ldots \ldots \ldots \ldots \ldots \ldots \ldots \ldots \ldots$

FIGURES

1-1. Waste management facility cost modules $\ldots \ldots \ldots \ldots \ldots \ldots \ldots \ldots \ldots \ldots \ldots$

1-2. PLCC cost estimating steps $\ldots \ldots \ldots \ldots \ldots \ldots \ldots \ldots \ldots \ldots \ldots \ldots \ldots \ldots \ldots$

1-3. Procedure for developing cost estimates from the WMFCI report $\ldots \ldots \ldots \ldots$

1-4. Comparison of three methods to obtain PLCC data between two cost estimate

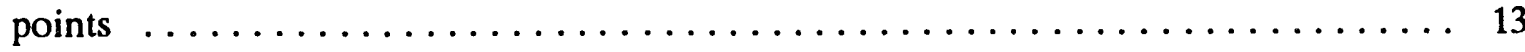

2-1. Front-end support facility process functional diagram $\ldots \ldots \ldots \ldots \ldots \ldots \ldots$

2-2. Cost versus capacity histogram for front-end treatment support facility $\ldots \ldots \ldots \ldots$

3-1. Cost versus capacity histogram for treatment receiving and inspection facility $\ldots \ldots \ldots 23$

4-1. Typical arrangement for alpha-LLW/LLMW open, dump, and sort facility $\ldots \ldots \ldots 25$

4-2. Open, dump, and sort facility process functional diagram $\ldots \ldots \ldots \ldots \ldots \ldots$

4-3. Cost versus capacity histogram for LLW/LLMW treatment open, dump,

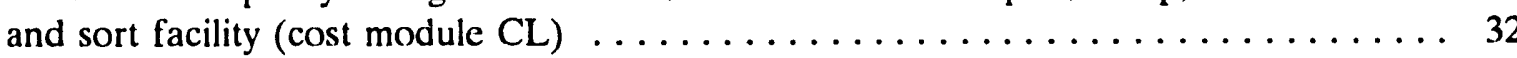

4-4. Figure 4-4 cost versus capacity histogram for alpha-LLW/LLMW treatment open, dump, and sort facility (cost module CA) $\ldots \ldots \ldots \ldots \ldots \ldots$

5-1. Typical arrangement for alpha-LLW/LLMW incineration facility $\ldots \ldots \ldots \ldots$

5-2. Incineration facility process functional diagram $\ldots \ldots \ldots \ldots \ldots \ldots \ldots \ldots \ldots$

5-3. Cost versus capacity histogram for LLW/LLMW incineration facility (cost module DL) 
5-4. Cost versus capacity histogram for alpha-LLW/LLMW incineration facility (cost module DA)

6-1. Typical arrangement for alpha-LLW/LLMW metal melting facility $\ldots \ldots \ldots \ldots$

6-2. Metal melting process functional diagram $\ldots \ldots \ldots \ldots \ldots \ldots \ldots \ldots$

6-3. Cost versus capacity histogram for LLW/LLMW metal melting facility (cost module EL).

6-4. Cost versus capacity histogram for alpha-LLW/LLMW metal melting facility

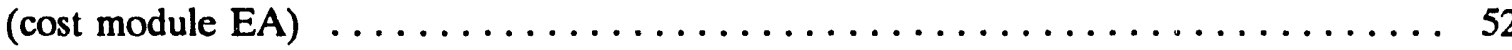

7-1. Typical arrangement for alpha-LLW/LLMW shredding/compaction facility $\ldots \ldots \ldots 55$

7-2. Shredding/compaction process functional diagram $\ldots \ldots \ldots \ldots \ldots \ldots \ldots \ldots$

7-3. Cost versus capacity histogram for LLW/LLMW shredding and compaction facility $($ cost module $\mathrm{FL}) \ldots \ldots \ldots \ldots \ldots \ldots \ldots \ldots \ldots \ldots \ldots \ldots \ldots \ldots \ldots$

7-4. Cost versus capacity histogram for alpha-LLW/LLMW shredding and compaction facility (cost module FA) $\ldots \ldots \ldots \ldots \ldots \ldots \ldots \ldots \ldots \ldots \ldots \ldots$

8-1. Typical arrangement for alpha-LLW/LLMW solidification facility $\ldots \ldots \ldots \ldots . \ldots 3$

8-2. Solidification process functional diagram $\ldots \ldots \ldots \ldots \ldots \ldots \ldots \ldots \ldots \ldots \ldots \ldots$

8-3. Cost versus capacity histogram for LLW/LLMW shredding and compaction facility (cost module GL)

8-4. Cost versus capacity histogram for alpha-LLW/LLMW shredding and compaction

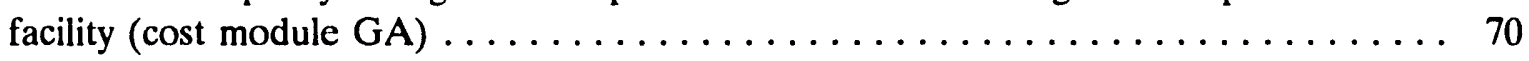

9-1. Typical arrangement for alpha-LLW/LLMW vitrification facility $\ldots \ldots \ldots \ldots$

9-2. Vitrification process functional diagram $\ldots \ldots \ldots \ldots \ldots \ldots \ldots \ldots \ldots \ldots \ldots \ldots \ldots$

9-3. Cost versus capacity histogram for LLW/LLMW shredding and compaction facility (cost module HL)

9-4. Cost versus capacity histogram for alpha-LLW/LLMW shredding and compaction facility $($ cost module $\mathrm{HA}) \ldots \ldots \ldots \ldots \ldots \ldots \ldots \ldots \ldots \ldots \ldots \ldots$

10-1. Certification/shipping facility process functional diagram. $\ldots \ldots \ldots \ldots \ldots 2$

10-2. Cost versus capacity histogram for treatment certification/shipping facility (cost module I). 
11-1. Cost versus capacity histogram for LLW/LLMW shredding and

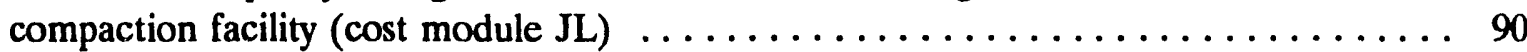

11-2. Cost versus capacity histogram for alpha-LLW/LLMW shredding and compaction facility (cost module JA) $\ldots \ldots \ldots \ldots \ldots \ldots \ldots \ldots \ldots \ldots \ldots \ldots$

12-1. Storage front-end/back-end support and storage facility process functional

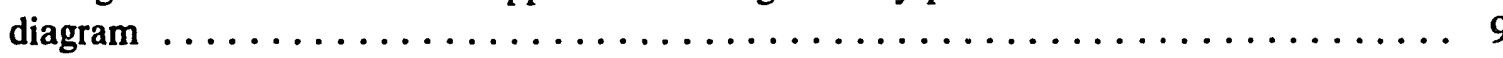

12-2. Cost versus capacity histogram for storage front-end/back-end support

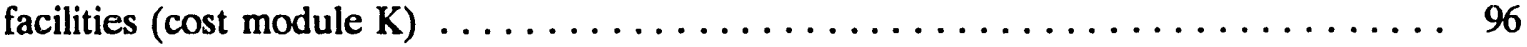

13-1. Cost versus capacity histogram for LLW, LLMW, alpha-LLW/LLMW,

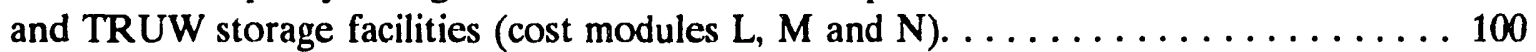

14-1. Disposal front-end facility process facility functional diagram $\ldots \ldots \ldots \ldots \ldots \ldots$

14-2. Cost versus capacity histogram for disposal front-end facility (cost module 0)

15-1. Disposal unit cutaway based on Illinois LLW disposal facility concept $\ldots \ldots \ldots \ldots 7$

15-2. Engineered disposal facilities process functional diagram $\ldots \ldots \ldots \ldots \ldots \ldots$

15-3. Cost versus capacity histogram for LLW and alpha-LLW engineered disposal facility (cost module P)

15-4. Cost versus capacity histogram for LLW and alpha-LLW engineered

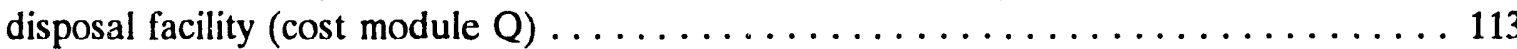

16-1. Cost comparison of commercial waste disposal facilities $\ldots \ldots \ldots \ldots \ldots \ldots \ldots \ldots$

18-1. Key events in the acquisition process $\ldots \ldots \ldots \ldots \ldots \ldots \ldots \ldots \ldots \ldots \ldots \ldots \ldots \ldots \ldots$

\section{TABLES}

1-1. Cost models summary $\ldots \ldots \ldots \ldots \ldots \ldots \ldots \ldots \ldots \ldots \ldots \ldots \ldots \ldots \ldots$

2-1. Estimated operating staff for front-end support (module A) $\ldots \ldots \ldots \ldots$

2-2. Capacity and cost information for front-end support facility (cost module A) $\ldots \ldots \ldots 16$

2-3. PLCC estimate summary for treatment front-end support facility (cost module A) . . 17

3-1. Estimated operating staff for front-end receiving and inspection facility (cost module B) 
3-2. Capacity and cost information for treatment receiving and inspection facility

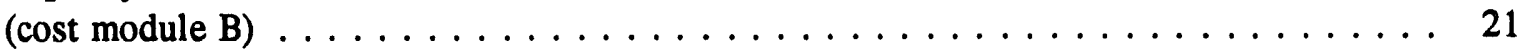

3-3. PLCC estimate summary for treatment receiving/inspection facility (cost module B) . . . . 22

4-1. Estimated operating staff for open, dump \& sort facility' (cost module CL and CA) . . . . 28

4-2. Capacities and cost information for open, dump and sort facility (cost modules CL

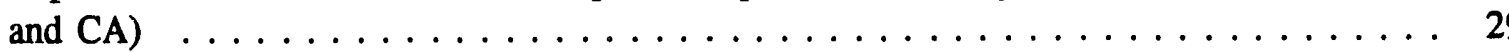

4-3. PLCC estimate summary for LLW/LLMW treatment open, dump, and sort facility

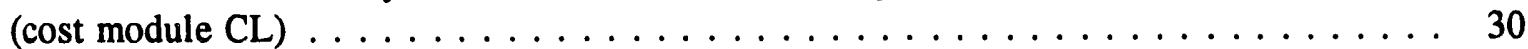

4-4. PLCC estimate summary for alpha-LLW/LLMW treatment open, dump,

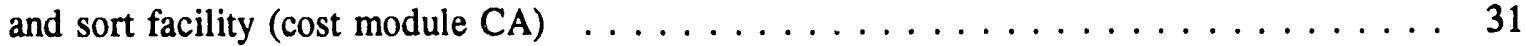

5-1. Estimated operating staff for incineration facility (cost module D) $\ldots \ldots \ldots$

5-2. Capacities and cost information for incineration facility (cost module DL and DA) . . . 38

5-3. PLCC estimate summary for LLW/LLMW incineration facility (cost module DL) . . . . . 39

5-4. PLCC estimate summary for alpha-LLW/LLMW incineration facility (cost module DA $\ldots \ldots \ldots \ldots \ldots \ldots \ldots \ldots \ldots \ldots \ldots \ldots \ldots$

6-1. Estimated operating staff for metal melting facility (cost module EL and EA) . . . . . 47

6-2. Capacities and cost information for metal melting facility (cost module EL and EA) . . . . 47

6-3. PLCC estimate summary for alpha LLW/LLMW metal-melting facility (cost module EL) . . . . . . . . . . . . . . . . . . . . . . . 49

6-4. PLCC estimate summary for alpha-LLW/LLMW metal-melting facility

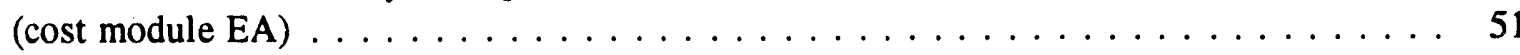

7-1. Estimated operating staff for shredding and compaction facility

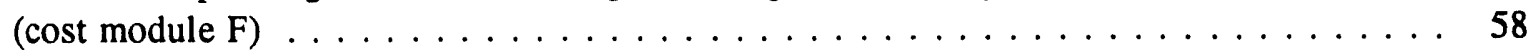

7-2. Capacities and cost information for shredding and compact facilities (module FL and FA) . 58

7-3. Rough order of magnitude (ROM) life-cycle cost for shredding and compaction . . . . . 59

7-4. ROM life-cycle cost estimate summary for alpha shredding and compaction . . . . . . . 60

8-1. Estimated operating staff for solidification facility (cost module GL and GA) . . . . . 67

8-2. Capacities and cost information for solidification facility (cost module GL and GA) . . . . 67 
8-3. PLCC estimate summary for LLW/LLMW solidification facility (cost module GL) . . . 68

8-4. PLCC estimate summary alpha-KLLW/LLMW solidification facility (cost

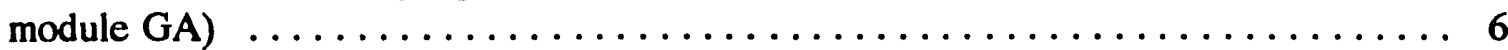

9-1. Estimated operating staff for vitrification facility (cost module $H$ ) $\ldots \ldots \ldots$

9-2. Capacities and cost information for vitrification facility (cost module HL and HA) . . 76

9-3. PLCC estimate summary for LLW/LLMW vitrification facility (cost module HL) . . . 78

9-4. PLCC estimate summary for alpha-LLW/LLMW vitrification facility (cost module $\mathrm{HA})$. . . . . . . . . . . . . . . 79

10-1. Estimated operating staff for certification/shipping facility (module I) $\ldots \ldots \ldots$. $\ldots 3$

10-2. Capacities and cost information for certification/shipping facility (cost module I). . . 83

10-3. PLCC estimate summary for treatment certification/shipping facility (cost module I)

11-1. Estimated operating staff for back-end treatment facilities (cost module $\mathrm{J}$ )

11-2. Capacities and cost information for treatment maintenance facility (cost module JL and JA)

11-3. PLCC estimate summary LLW/LLMW treatment maintenance facility (cost module JL)

11-4. PLCC estimate summary alpha-LLW/LLMW treatment maintenance facility (cost module JA)

12-1. Estimated operating staff for storage support facilities (cost module $\mathrm{K}$ )

12-2. Capacities and cost information for storage front-end and/back-end facility (cost module $\mathrm{K}$ )

12-3. PLCC estimate summary for storage front-end/back-end support facility (cost module $\mathrm{K}$ )

13-1. Estimated operating staff for storage areas (modules $\mathrm{L}, \mathrm{M}$, and $\mathrm{N}$ )

13-2. Capacities and cost information for storage facility (cost module L, M, and N) 
13-3. PLCC estimate summary for LLW/LLMW, alpha-LLW/LLMW and TRUW facility (cost modules $\mathrm{L}, \mathrm{M}$, and $\mathrm{N}) \ldots \ldots \ldots \ldots \ldots$

14-1. Estimated operating staff for disposal front-end facility (cost module 0)

14-2. Capacities and cost information for disposal front-end facility (cost module 0 ) 103

14-3. PLCC estimate summary for disposal common support facility (cost module 0 ) 104

15-1. Estimated operating staff for disposal facility (cost modules $\mathrm{P}$ and $\mathrm{Q}$ ) $\ldots \ldots \ldots$

15-2. Capacities and cost information for engineering disposal facility (cost module $P$ and $Q$ ) . . 110

15-3. PLCC estimate summary for alpha-LLW and LLW engineered disposal

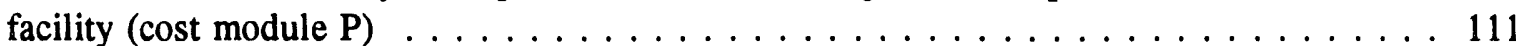

15-4. PLCC estimate summary for alpha-LLMW engineered disposal facility

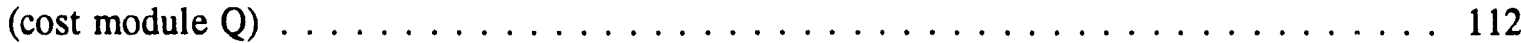

16-1. Closure and shallow land disposal capacities and costs (cost module R) . . . . . . . . . 114

18-1. WMFCI cost modules $\ldots \ldots \ldots \ldots \ldots \ldots \ldots \ldots \ldots \ldots \ldots$

18-2. Waste treatment weight conversion factors $\ldots \ldots \ldots \ldots \ldots \ldots \ldots \ldots$

18-3 Summary costs and capacities for treatment facilities $\ldots \ldots \ldots \ldots \ldots \ldots \ldots$

18-4. Summary costs and capacities for storage facilities $\ldots \ldots \ldots \ldots \ldots \ldots \ldots$

18-5. Summary costs and capacities for disposal facilities . . . . . . . . . . . . . . 125

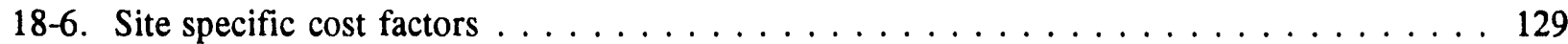


xviii 


\section{ACRONYMS}

alpha-LLMW Alpha contaminated low-level mixed waste

alpha-LLW Alpha contaminated low-level waste

B\&W Babcock \& Wilcox

BWSDS Buried Waste System Design Study

D\&D Decontamination and Decommissioning

DOE U.S. Department of Energy

DOE-ID U.S. Department of Energy Idaho Field Office

EIS Environmental Impact Statement

F\&OR Functional and operational requirement

FAST Freiman Analysis of System Technique

FTE Full time equivalent

GOCO Government ouned and contractor operated

HDPE High-density polyethylene

INEL Idaho National Engineering Laboratory

LDR land disposal restriction

LICP Line Item Construction Project

LLRWPAA Low-Level Radioactive Waste Policy Amendment Act

LLW low-level waste

LLMW low-level mixed waste

MCC Motor Control Center

MK Morrison Knudsen Corporation, Environmental Services Division

NEPA National Environmental Policy Act of 1969

NRC Nuclear Regulatory Commission 


\begin{tabular}{|c|c|}
\hline O\&M & Operations and Maintenance \\
\hline ORNL & Oak Ridge National Laboratory \\
\hline PAN & Passive/active neutron \\
\hline PEIS & Programmatic Environmental Impact Statement \\
\hline PFD & Process functional diagram \\
\hline PLCC & Planning life-cycle cost \\
\hline RCRA & Resource Conservation and Recovery Act \\
\hline RHMMS & Radiological and Hazardous Material Measurement System \\
\hline $\mathrm{RI} / \mathrm{FS}$ & Remedial Investigation/Feasibility Study \\
\hline ROM & Rough order of Magnitude \\
\hline RTR & Real-time radiography \\
\hline RWMC & Radioactive Waste Management Complex \\
\hline SEG & Scientific Ecology Group, Oak Ridge \\
\hline SGS & Segmented Gamma Scanning \\
\hline SSL & Scoping Study Layout \\
\hline SWSDS & Stored Waste System Design Study \\
\hline TRAMPAC & transportation package \\
\hline TDS & Treatment, storage, and disposal \\
\hline TRU & transuranic \\
\hline TRUW & transuranic waste \\
\hline TSCA & Toxic Substance Control Act \\
\hline WIPP & Waste Isolation Pilot Plant \\
\hline WMFCI & Waste Management Facility Cost Information \\
\hline
\end{tabular}




\section{Waste Management Facilities Cost Information}

\section{INTRODUCTION AND SUMMARY}

\subsection{Background}

The Waste Management Facility Cost Information (WMFCI) report describes the results of a task commissioned by the U.S. Department of Energy (DOE) to develop cost information for the treatment, storage, and disposal (TSD) facilities that will support DOE's multisite waste management facility siting strategy. The report is intended to provide planning level life-cycle cost (PLCC) estimates for TSD facilities that will be needed for DOE in the preparation of the Programmatic Environmental Impact Statement (PEIS). The estimates are based on a set of facility cost modules, each of which may be used alone or combined. All facilities are assumed to be government owned and contractor operated (GOCO).

The scope of this report includes cost estimates for facilities that manage low-level waste (LLW), low-level mixed waste (LLMW), alpha low-level wastes (alpha-LLW), alpha low-level mixed waste (alpha-LLMW), and transuranic waste (TRUW). Estimates are provided for TSD facilities with a wide range of size and throughput capacities for all waste types except the TRUW. Since the current DOE strategy is to dispose of TRUW in the Waste Isolation Pilot Plant (WIPP), only interim storage and disposal facilities are estimated for this type of waste. Facilities do not include TSDs for greater than Class $\mathrm{C}$ waste. Cost information in this report is based on the best available knowledge about waste processing requirements, technology availability, and cost data. The information in this report may have to be updated when more knowledge is gained in these areas.

\section{2 "WMFCl" Task Participants}

The WMFCI task was completed by a project team from EG\&G Idaho, Inc. and the Environmental Services Division of Morrison Knudsen Corporation (MK). EG\&G Idaho and MK were selected for this task because of their combined expertise in design and construction of waste management TSD facilities for DOE sites and for the nuclear industry (e.g., Waste Characterization Facility at INEL and the Illinois Low-Level Radioactive Waste Disposal Facility). EG\&G Idaho has also prepared a buried waste system design study (BWSDS) ${ }^{1}$ and a stored waste system design study (SWSDS) $^{2}$ with the support of $\mathrm{MK}$ and other engineering firms, to evaluate treatment system concepts. The treatment system design concepts and planning level cost estimates addressed in BWSDS and SWSDS are directly applicable to the WMFCI task.

EG\&G Idaho provided the overall project management and technical guidance for the study and coordinated preparation of the final report. MK developed preconceptual design packages and prepared PLCC estimates for the facilities. 


\subsection{Cost Modules and Unit Operations}

Each type of TSD facility (common support treatment through final disposal) is referred to as a cost module. There are a total of 26 cost modules (labelled A through S), shown in Figure 1-1. These cost modules can be assembled in various ways to create different types of TSD scenarios. As shown, treatment cost modules are provided for two general categories of waste: LLW/LLMW and alpha-LLW/LLMW. Cost modules for storage and disposal include LLW, LLMW, alphaLLW/LLMW, and TRUW facilities.

Each facility is broken down into several distinct functions, referred to as unit operations. Unit operations assume inclusion of all buildings, equipment, and accessories needed to accomplish the given function.

\subsection{Facility Cost Estimating Methodology}

Details of the approach used for developing PLCC estimates in this report are presented in Appendix A. Figure 1-2 shows a block diagram of the steps used in the estimating process. Initially, a capacity range for each type of facility was established by studying the stored and newly generated wastes at various DOE sites. The capacities were based on the total mass or volumes of waste to be processed during a 20-year period. Data from the study defined baseline capacities for three different facility sizes: small, medium, and large. Whenever possible, the baseline capacities were selected to be the same as an existing facility. For example, the medium baseline capacity for incineration is the same as the nominal capacity of the Toxic Substance Control Act (TSCA) incinerator that is currently operating at the Oak Ridge National Laboratory (ORNL). This approach, referred to as "anchoring," provided a reference point that could be used as the basis for estimating the various cost components. Furthermore, anchoring facilitated comparison of the estimates in this report with either the actual costs incurred by an operating facility or estimates of facilities that are in an advanced design and construction stage.

Using the three capacities for each facility, preconceptual design packages were developed for each facility and used as the basis for PLCC cost estimates. Each preconceptual design package included a process functional diagram (PFD) with mass flow rates, a scoping study layout (SSL), and a summary functional and operational requirements (F\&OR). The PFD and SSL drawings were developed to the individual unit operations level. After unit operations were defined, major equipment lists and building square footage requirements were established for each unit opcration. The design packages utilized as much of the data from existing or planned commercial and DOE

a. In this report, "anchor" facilitie: lenote reference facilities that are either in operation or in advanced design and construction stage. "Anchoring" denotes using technical data and capital, operating, and maintenance costs incurred by an anchor facility as a measuring stick in development of the PLCC estimates. Before adopting costs from an anchor facility, they were adjusted to account for any differences in technical requirements and cost escalation. Major anchor facilities are TSCA incinerator at ORNL, Scientific Ecology Group (SEG) waste management facility (incinerator and metal-melting) in Oak Ridge, Simplekemp metal melting facility in Germany, Babcock and Wilcox $(B \& W)$ compaction facility in Lynchburgh, and Illinois radioactive waste disposal facility. 


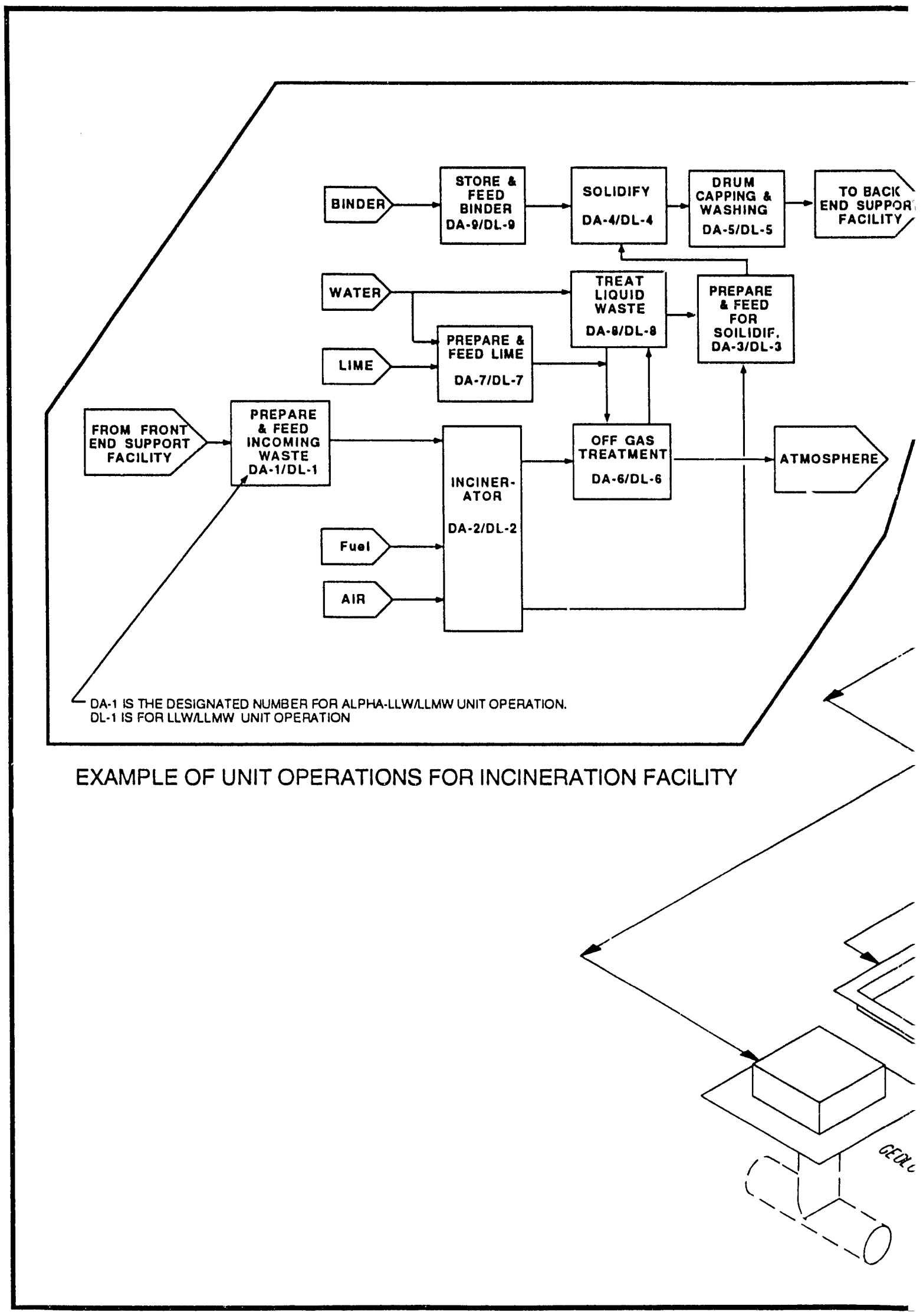

Figure 1-1. Waste management facility cost modules. 


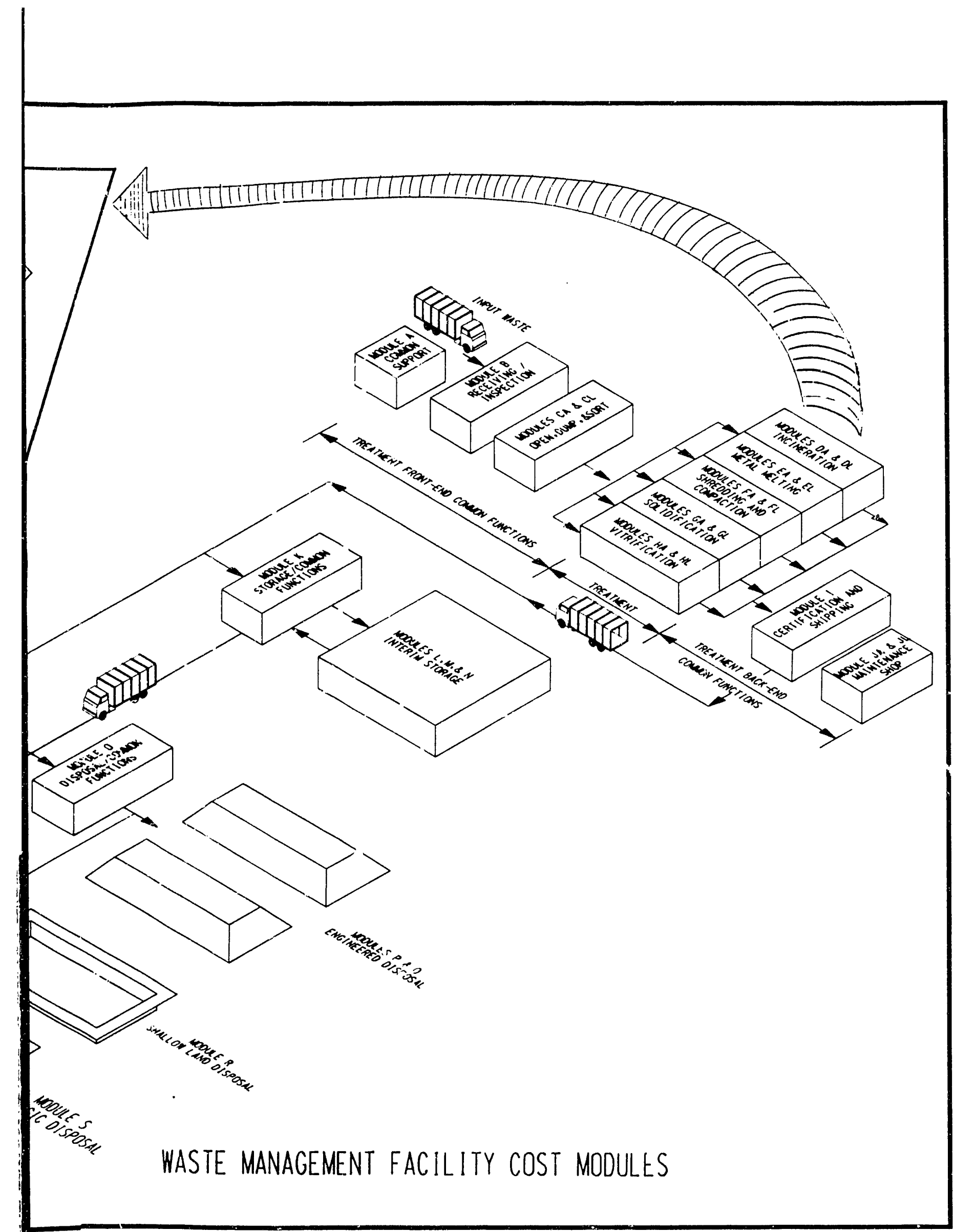

F:\WMF 720 \mainwmf.fin 


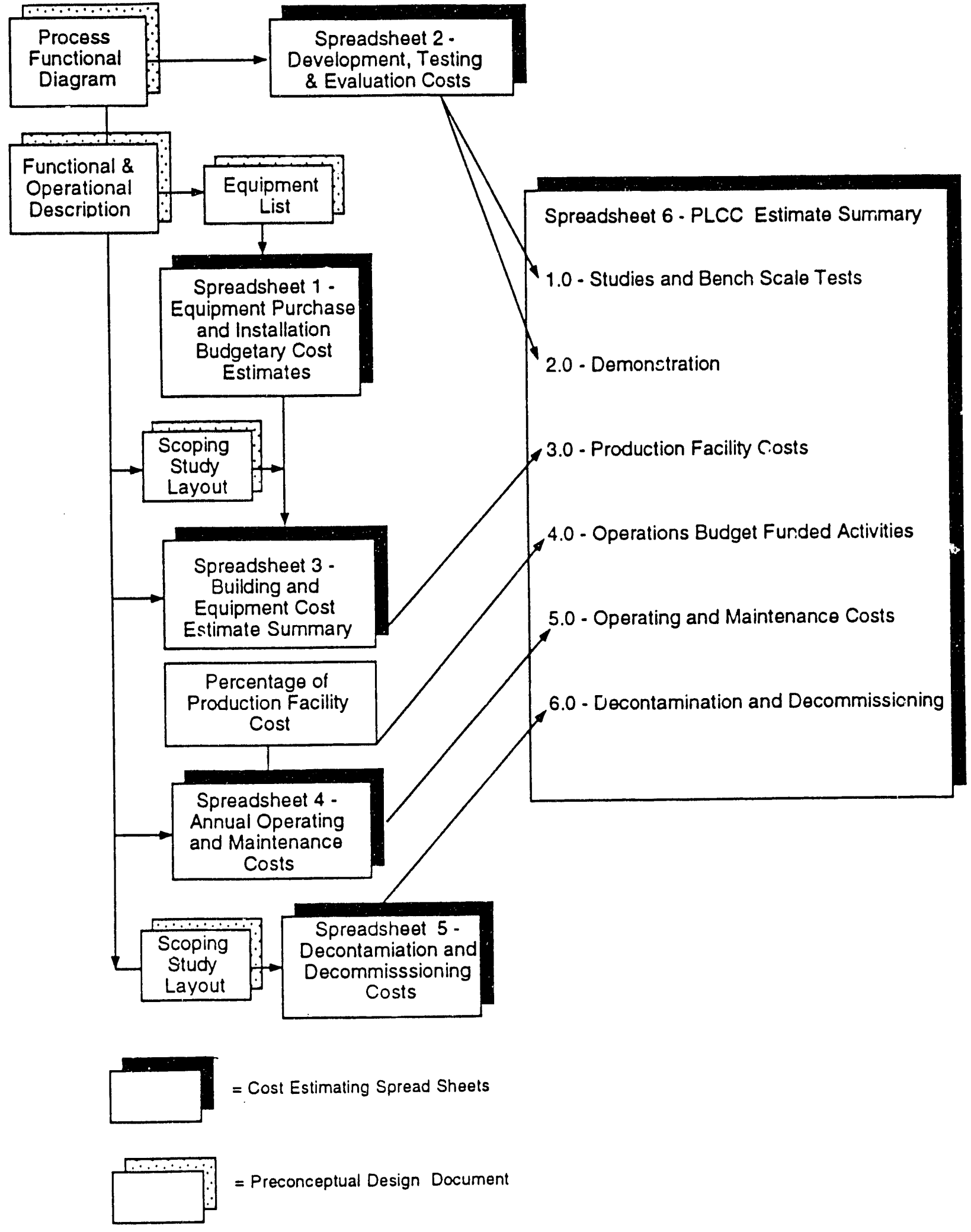

Figure 1-2. PLCC cost estimating steps. 
(anchor) facilities as possible. New designs were generated only if existing data were not available.

PLCC cost for each facility was divided into six components (see Figure 1-2), each of which were estimated separately. Cost for the first and second cost components, (studies and bench scale tests, and demonstration) were estimated by obtaining research manpower and equipment estimates from the Stored Waste System Design Study (SWSDS) report. ${ }^{2}$ The third cost component, production facility construction costs, consists of two key subcomponents, equipment and building cost. The major equipment lists were used to obtain cost estimates either from another similar or anchor facility, soliciting budgetary costs from the suppliers, or making engineering judgements. Building costs were estimated by multiplying building unit costs by the space square footage allocated to each unit operation in the SSLs.

Once the equipment and building costs were estimated for each facility, they were totalled and multiplied by a percentage to allow for the construction contractor indirect costs. The sum of the equipment, building, and indirect costs were further multiplied by appropriate factors to allow for design, inspection, construction management, and project management costs. Allowances were also included for management reserve and contingencies.

The fourth cost component, operations budget funded activities, includes conceptual design, safety assurance, National Environmental Policy Act of 1969 (NEPA) and permitting, preparation for operation, and project management costs. The NEPA and permitting activities costs were estimated at \$6 million for a full NEPA, an environmental impact statement (EIS) process, and \$1 million for an environmental assessment process. All other subcomponents of the operations budget funded activities cost were estimated as a percentage of the construction cost.

The fifth cost component, operating and maintenance (O\&M) costs consists of operating labor, utilities, materials, maintenance parts and equipment, and maintenance labor costs. The first three sub-components, operating labor, utilities, and consumable materials were estimated based on analyzing the requirements of each facility at the unit operations level. The remaining two subcomponents, maintenance equipment and labor costs, were estimated as a percent of the original equipment installed at the facility. The sixth cost component, decontamination and decommissioning (facility closure), was estimated by multiplying a decontamination and decommissioning (D\&D) unit rate by the facility square footage. For disposal facilities, long-term maintenance and monitoring costs were also added to the D\&D cost. The facility total PLCC estimates were obtained by adding the six cost components.

To facilitate cost estimating flexibility, the front-end and back-end functions (e.g., receiving, staging, and storage, incoming waste assay and inspection, incoming waste open, dump, and sort, outgoing waste assay and certification, and support facilities such as administration, maintenance shop, analytical laboratory) of each treatment, storage, and disposal facility are estimated as separate cost modules. This approach allows consideration of scenarios that involve existing facilities where some or all of the front-end and back-end functions are already in place.

\subsection{Waste Management Scenario Costing Procedure}

To guide the DOE and its subcontractors in the use of this report, a procedure for developing cost estimates was established. The procedure allows the user to easily project the overall cost of a 
given waste TSD alternative. The procedure (Figure 1-3) is based on seven basic steps, summarized below, to obtain the PLCC estimates:

1. Define the overall waste management TSD alternative.

2. Define parameters including type of waste, waste volumes, locations of waste, and combination of TSD facilities.

3. Select the required treatment cost modules, and if appropriate, front-end and back-end support cost modules, and obtain the corresponding PLCC estimates by selecting one of the cost modules closest to the required capacity from the cost/capacity graphs or tables in Sections 2 through 11 of this report.

4. Select the required storage cost modules and, if applicable, front-end/back-end support module and obtain the corresponding PLCC estimates by selecting one of the cost modules closest to the required capacity from cost/capacity graphs or tables in Sections 12 and 13 of this report.

5. Select the required disposal cost modules and, if applicable, front-end support module and obtain the corresponding PLCC estimates by selecting one of the cost modules closest to the required capacity from cost/capacity graphs or tables in Sections 14 and 15 of the report, unless shallow land disposal or deep geological repository is required. In such cases, refer to Sections 16 and 17 where cost estimates may be applied.

6. Calculate transportation costs using data given in Section 18 of the report.

7. Add items 3 through 6 to yield the total PLCC estimates for the given waste management alternative.

A detailed description of the procedure is presented in Section 18.

\subsection{Cost Assessment Activities}

To the extent possible, major equipment costs in each cost module were compared with data from anchor facilities to establish a cost confidence level within the boundaries established for the PLCC estimates. Both the DOE and the commercial nuclear industry are now planning or operating similar facilities. These facilities were surveyed to obtain capacity, cost data, and other information needed to support the WMFCI data. Before using these costs, the data was adjusted to account for capacity differences and escalation.

Additional assessment activities included a review of applicable cost models that could be used to analyze and verify the cost estimates from this study. Various cost estimating models are currently available or under development for potential use in a DOE report. ${ }^{3}$ Table 1-1 summarizes the review of 11 cost models and the relevant areas of applicability to this study. The majority of these cost models were developed for estimating environmental restoration and construction costs. The primary applicability of these models are front-end/back-end support facilities, commercially available (nonradioactive) equipment, and unit costs for hazardous waste treatment. None of the models 


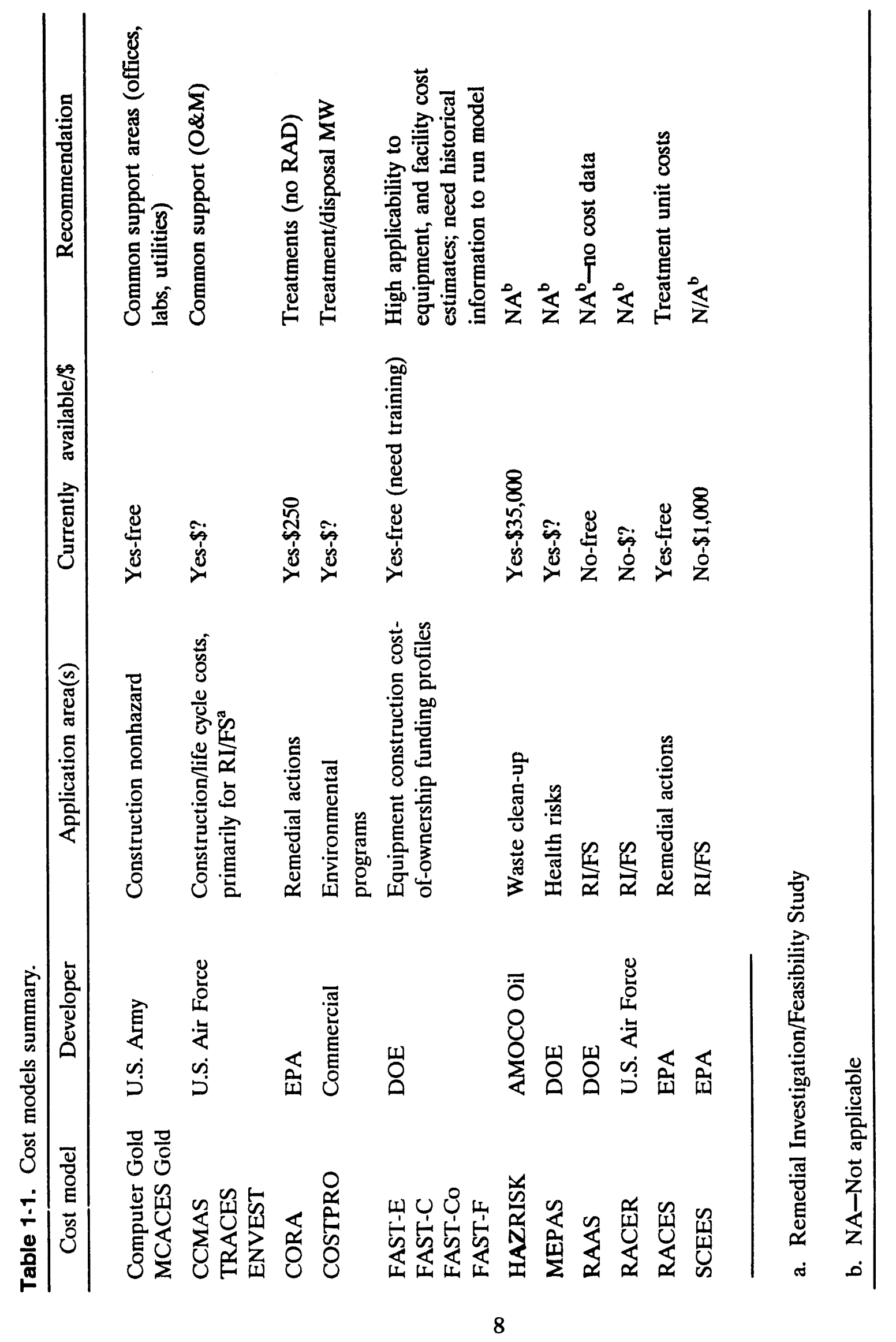




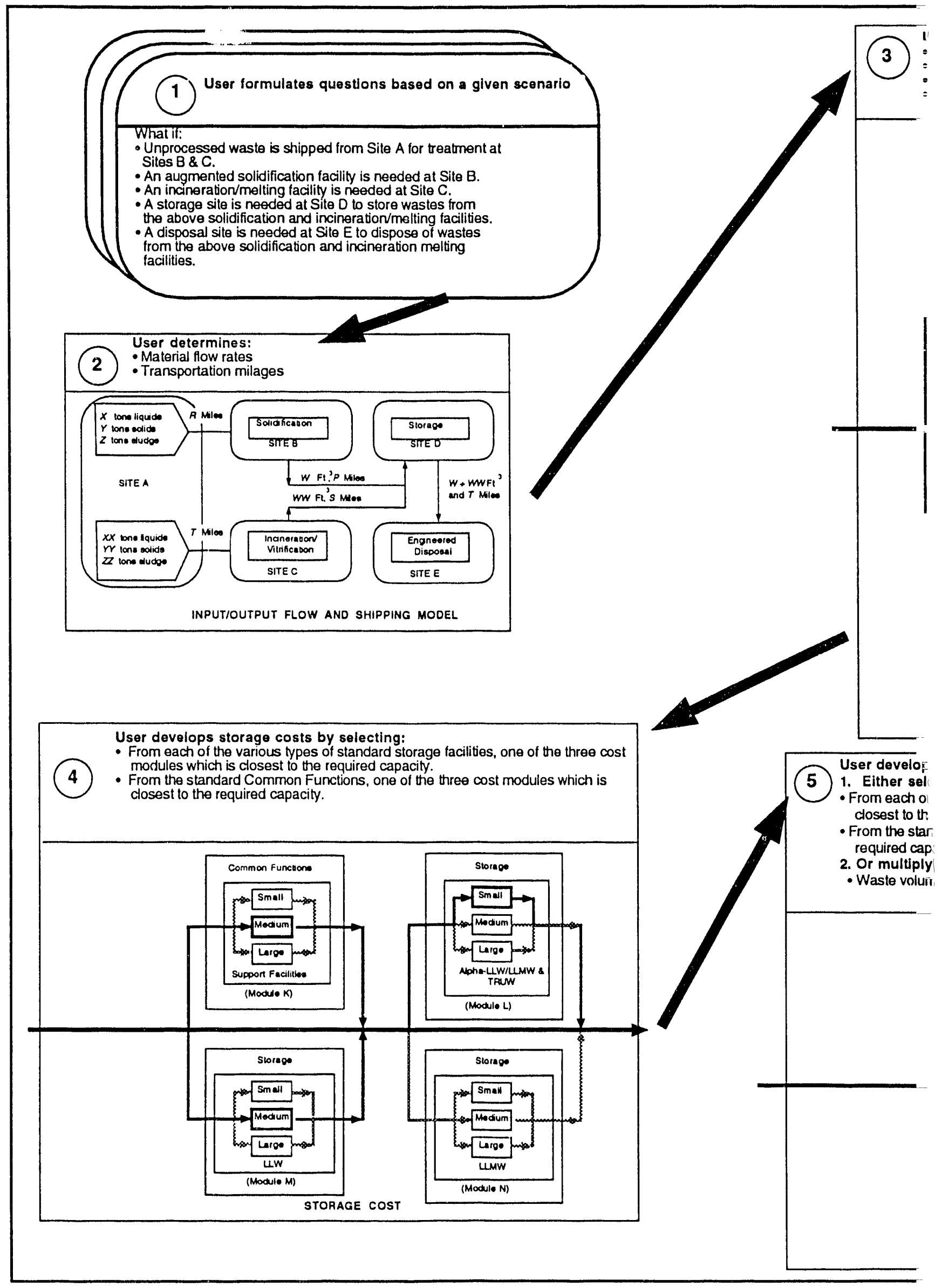

Figure 1-3. Procedure for developing cost estimates from the WMFCI repori. 
ser develops treatment costs by selecting:

From the standard solidification facilities, one of the three cost modules which is closest to the required capacity.

From the standard incineration facilities, one of the three cost modules which is closest to the required capacity.

From the standard vitrification facilities, one of the three cost modules which is closest to the required capacity.

From each of the various types of standard common functions, one of the three cost modules which is closest to the required capacity.

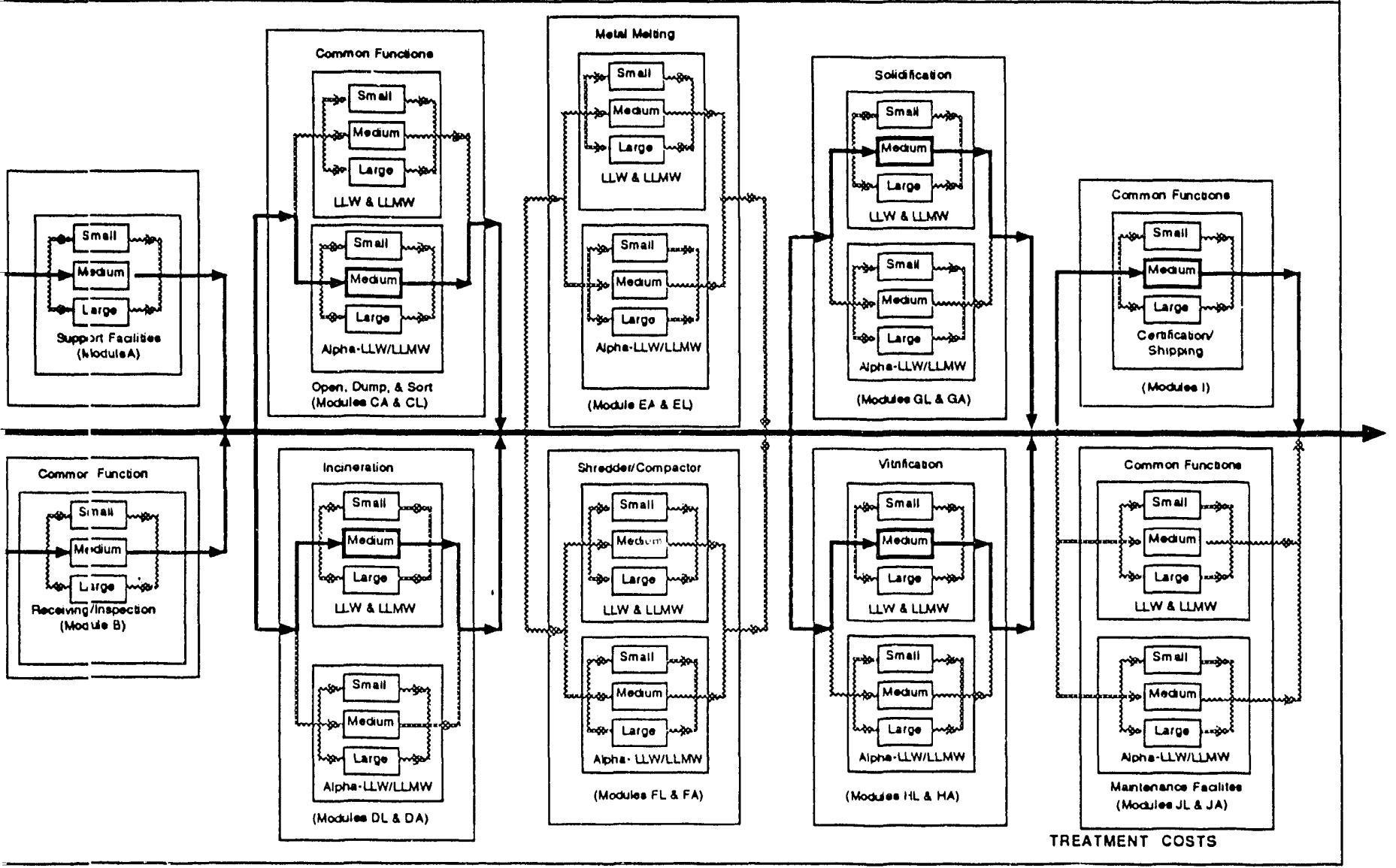

disposal costs by:

cting:

he various types of standard disposal facilities, one of the three cost modules which is required ciapacity.

jard Comm ron Functions, one of the three cost modules for which is closest to the

city.

3 by the stiandard disposal unit rates.

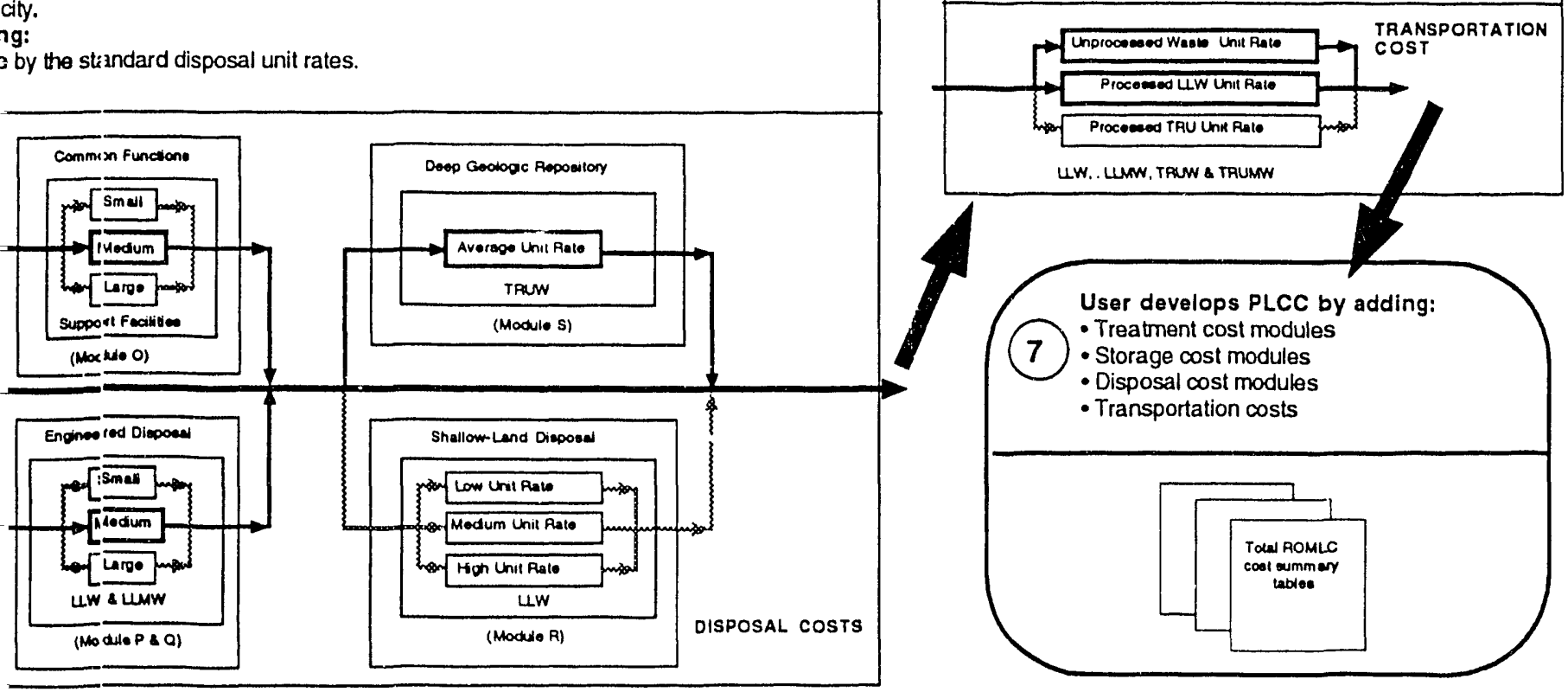

6 User develops transportation costs by multiplying :

- Waste volumes by the standard transportation unit rates and the milage. 
currently address costs of equipment and construction in LLW/LLMW, or alpha environments for the WMFCI treatment, storage, or disposal facilities.

The most applicable cost models from this study are the Freiman Analysis of Systems Technique (FAST) Models C, E, and CO. With FAST the data from this study can be used to develop parametric cost relationships that could be highly valuable in the future for specific cost studies. Potential applications include (a) validation of the WMFCI cost/capacity curves based on intermediate capacities, (b) validation of existing cost estimates, (c) utilization for new facility cost estimates, and (d) use for other DOE-HQ initiatives. The information generated by the WMFCI study could be readily incorporated into the FAST model for future use by DOE.

\subsection{Report Organization}

Section 1 of this report contains background and summary information of the PLCC estimates. The cost estimating methodology, general assumptions, and basis used in developing PLCC estimates are presented in Appendix A.

Sections 2 through 17 summarize each TSD cost module. Sections 2 through 17 provide only a description of activities and assumptions that apply to the specific process in each section. Additional general assumptions and cost bases that apply to most or all cost modules are included in Appendix A.

Section 18 presents procedures and summary cost and capacity information for costing various waste management scenarios. PLCC estimate baskup information is included in EG\&G Idaho report. ${ }^{4}$ A scenario costing worksheet is provided in $A$ ppendix $B$ to aid the user of this report in the preparation of PLCC estimates for a specific scenario. A scenario costng worksheet is provided in Appendix B to aid the user of this report in the preparation of PLCC estimates for a specific scenario.

\subsection{Limitations}

Section 18 and Appendix A of this report must be consulted regarding limitations and qualifications that apply to development of PLCC estimates for various waste management options. To apply cost data from this report, at a minimum, the reader must ensure that the cost of front-end and back-end support facilities is incorporated. Front-end and back-end cost modules generally include PLCC estimates associated with functions such as waste receiving/inspection, container opening, dumping and sorting, certification and shipping of the packaged waste, analytical laboratory, maintenance shop, and facility administration, environmental and health compliance, security, and related activities.

Data extrapolation from PLCC estimate histograms given in Sections 2 through 17 should be done with caution (the reader should note that this task developed estimates only for those capacities shown as the estimate points on the histograms). Most of the cost components (such as facility capital and operating laobr cost) do not change significantly within a given capacity range. Only a minor portion of the cost (components such as power consumption, consumable materials, and maintenance costs) has direct relationship with the quantity of the waste process by the facility. 
Figure 1-4 shows three different ways that can be used to estimate PLCC for a facility having a capacity not the same as an estimate point. The first method, straight line, is extrapolating data from a straight line drawn between two estimate points. The second method, most probable PLCC capital estimate, is adding the fixed costs (those that are believed to be fixed within a given capacity range) to the variable costs (those that vary with the capacity). The third method, the histogram, is selecting an estimate point closest to the required capacity. The following conclusions are reached when the three methods are used to get PLCC estimates for an alpha incineration facility with a required capacity at mid-point between the small and medium estimate points.

1. The added cost uncertainty is greatest at a mid-point between two estimate points.

2. If a histogram method is used, the estimated PLCC is about $11 \%$ more or less than the most probable cost method.

3. If a straight line method is used, the estimated PLCC is $12 \%$ more or less than the most probable cost method. 


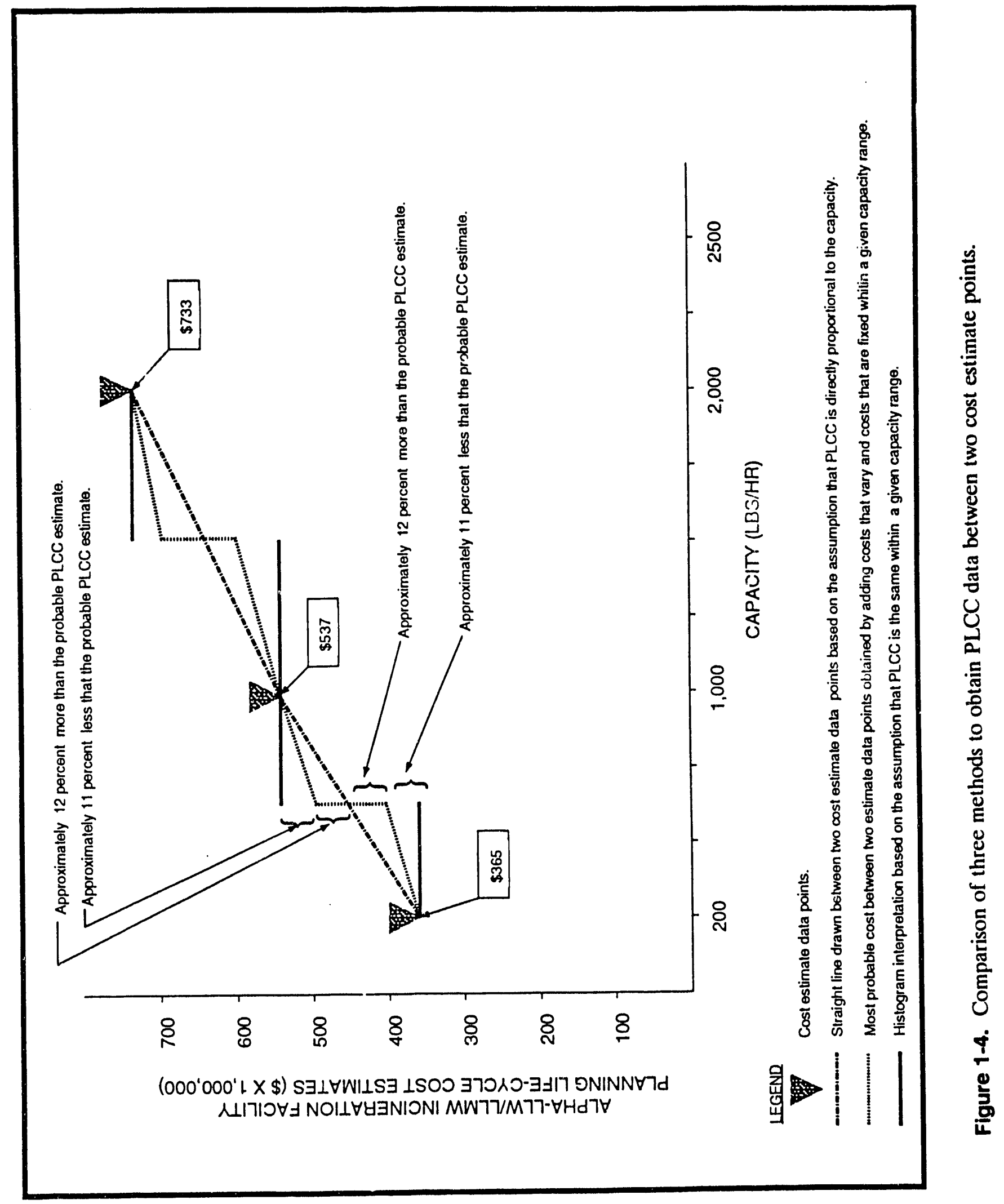




\section{TREATMENT FRONT-END SUPPORT FACILITY (COST MODULE A)}

\subsection{Basic Information}

Front-end support facilities include all administrative and laboratory buildings required for the waste management support functions. The front-end support facilities are essentially the same for all treatment cost modules. Any differences will depend on the type of equipment needed for different waste management activities within the facility and will not change the general layout. Front-end support facilities, whether for treatment, storage, or disposal, should be used whenever a new facility is planned. Unit operations are shown in Figure 2-1.

\subsection{Technical Bases and Requirements}

All front-end support cost modules incorporate all support functions needed to manage the operation of a waste management facility. These functions include security, personnel decontamination (radioactive and hazardous), maintenance of noncontaminated areas/equipment, health physics/radiation badges/facility access control, sanitary facilities, work control/personnel support, internal and external (public relations) communications, spill or emergency response provisions (hazardous and radioactive), analytical laboratory, environmental field sampling, environmental regulatory reporting, and records management.

\subsection{Cost Bases, Assumption, Assessments}

The treatment facility front-end support module is the same for both LLW/LLMW and alphaLLW/LLMW waste types. General cost bases and assumptions are given in Appendix A. Facility specific items are discussed below.

- Major equipment capital cost items are laboratory analytical equipment. For a small common support facility, $\$ 1$ million allowance is made for analytical instruments and components needed for a mixed waste laboratory.

- Estimating operating staff is shown in Table 2-1.

- Mixed waste laboratory vendors have been consulted to ensure that the laboratory allowance is adequate.

- Small, medium, and large facility capacitics and unit costs are shown in Table 2-2.

\subsection{Cost Summaries}

Cost summary for the front-end support facility is shown in Table 2-3. A histogram of cost versus capacily is shown in Figure 2-2. 


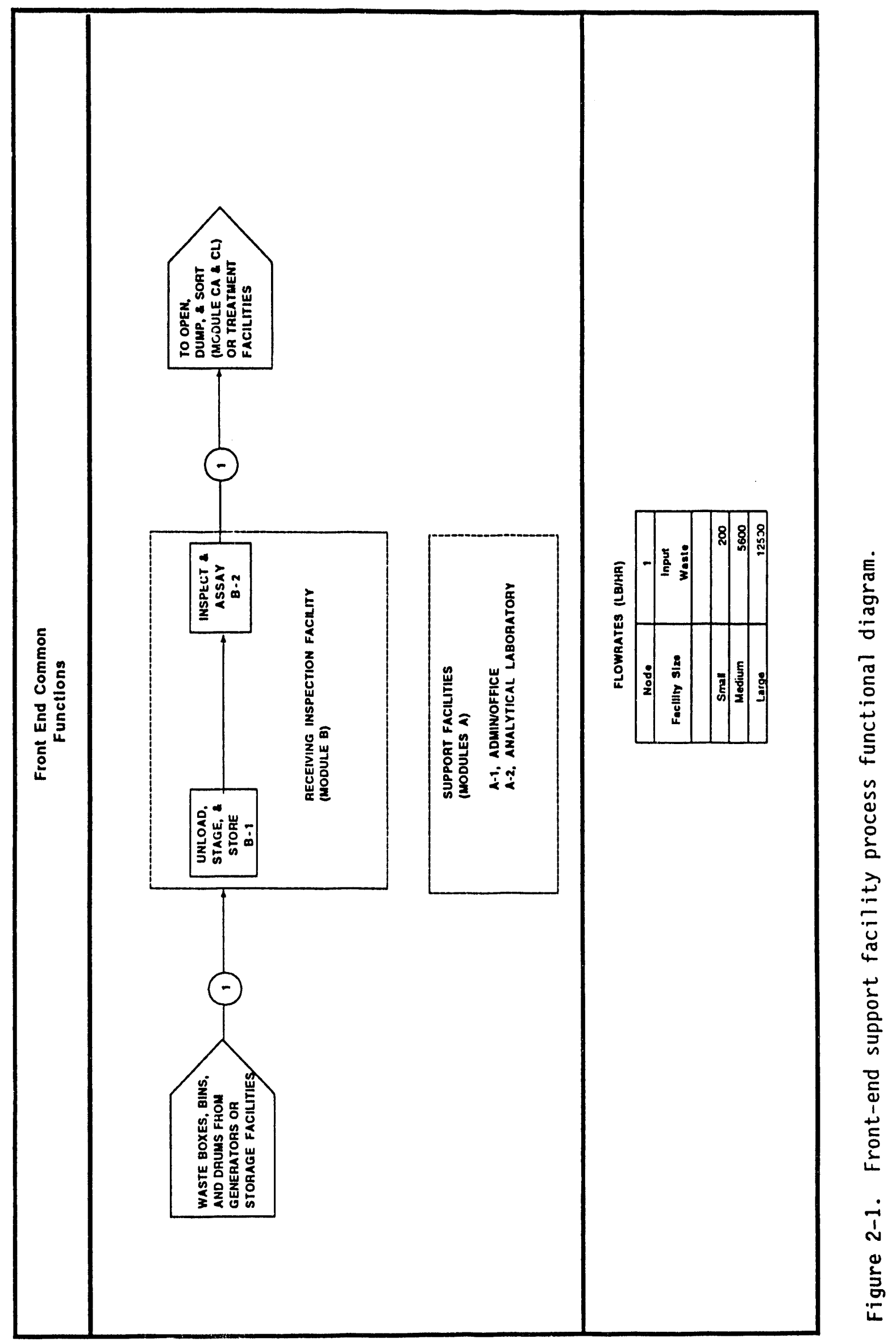


Table 2-1. Estimated operating staff for front-end support (module A).

\begin{tabular}{|c|c|c|c|c|}
\hline $\begin{array}{c}\text { Unit } \\
\text { Operation }\end{array}$ & Description & $\begin{array}{c}\text { Small } \\
(\mathrm{FTE})^{\mathrm{a}}\end{array}$ & $\begin{array}{c}\text { Medium } \\
\text { (FTE) }\end{array}$ & $\begin{array}{l}\text { Large } \\
\text { (FTE) }\end{array}$ \\
\hline \multirow[t]{12}{*}{ A-1 } & Administration office: & & & \\
\hline & Accountant & 1 & 3 & 4 \\
\hline & Secretarial/clerk & 2 & 5 & 10 \\
\hline & Document control & 2 & 4 & 7 \\
\hline & Manager-dayshifts & 2 & 5 & 9 \\
\hline & Technical personnel & 1 & 4 & 8 \\
\hline & Communications & 1 & 2 & 3 \\
\hline & Environmental manager & 1 & 4 & 9 \\
\hline & Oper. support/mgmnt. & 1 & 4 & 9 \\
\hline & Quality control technicians & 1 & 4 & 9 \\
\hline & Security guard & 4 & 7 & 13 \\
\hline & Health physics tech. & 4 & 7 & 13 \\
\hline \multirow[t]{2}{*}{ A-2 } & Testing laboratory & 7 & 12 & $\underline{18}$ \\
\hline & Total & 27 & 61 & 112 \\
\hline
\end{tabular}

Table 2-2. Capacity and cost information for front-end support facility (cost module A). ${ }^{\mathrm{a}}$

\begin{tabular}{|c|c|c|c|c|c|c|c|c|}
\hline Mod. & Module & Facility & Life Cycle Cos & Capacity & Unit Cost & Capacity & Cap(Tot Vol) & Unit Cost \\
\hline & Description & & $(\$ \times 1000)$ & $(\mathrm{lbs} / \mathrm{hr})$ & $(\$ / 1 b)$ & $(f+3 / h r)$ & $(f+3 \times 1000)$ & $(\$ / f t 3)$ \\
\hline & & & & & & & & \\
\hline A & IC1n & $\mathrm{Sm}$ & $\$ 1$ & 200 & $\$ 7.99$ & $\overline{6}$ & 461 & $\$ 279.7$ \\
\hline A & ment $s$ & $\mathrm{Mec}$ & 58 & 5,600 & $\$ 0.64$ & 160 & 12,902 & $\$ 22.4$ \\
\hline$\cdots$ & Treatment Support & Large & $\$ 530,763$ & 12,500 & $\$ 0.53$ & 357 & 28,800 & $\$ 18.43$ \\
\hline
\end{tabular}

a. Average density used is $35 \mathrm{lbs} / \mathrm{ft}^{3}$ 
Table 2-3. PLCC estimate summary for treatment front-end support facility (cost module A).

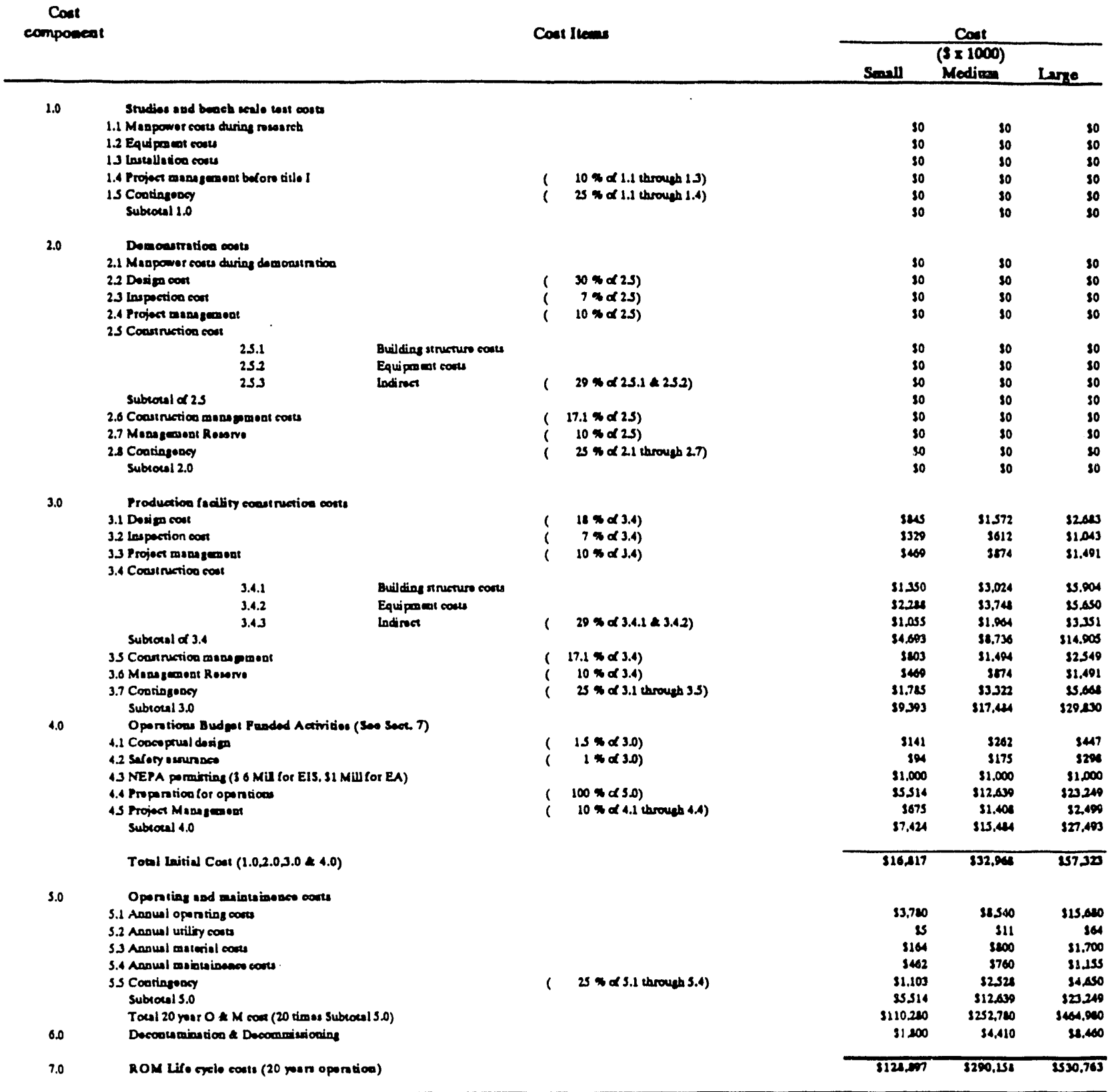




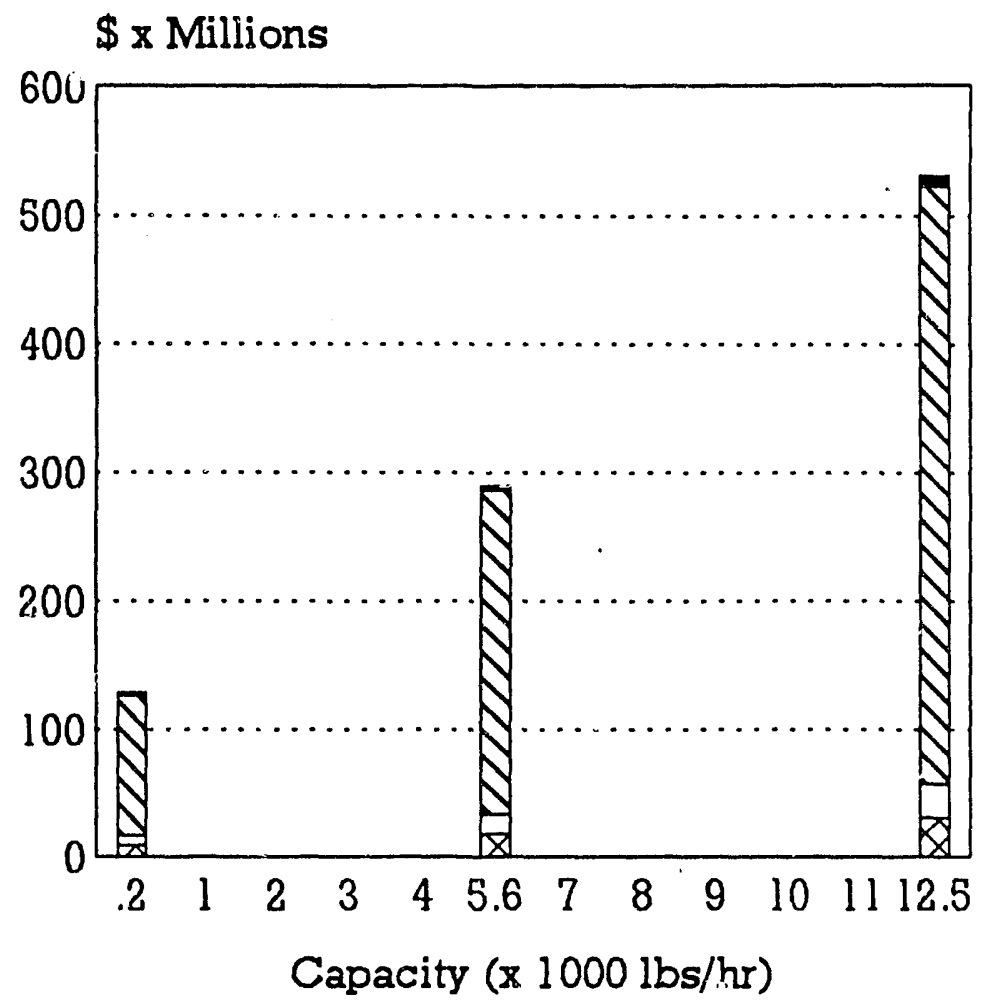

Deoontam \& Deoomm D20 Yrs O \& M Costs $\square$ Oper. Bud. Funded Aat. BProduation Fac. Const.

Figure 2-2. Cost versus capacity histogram for front-end treatment support facility. 


\section{TREATMENT RECEIVING AND INSPECTION FACILITY (COST MODULE B)}

The receiving and inspection facility is effectively the same for LLW/LLMW and alphaLLW/LLMW waste types. There are minor differences in the assay/inspection equipment that are negligible at a PLCC estimate level. Unit operations are given in Figure 2-1.

\subsection{Basic Information}

The receiving and inspection facility is intended to be contiguous with the container open, dump, sort, and the waste treatment facilities. It consists of two unit operations: unload/stage and inspect/assay. The waste containers (drums, boxes and metal bins) arrive at the receiving and inspection facility on a transport vehicle. Containers are removed from the transport vehicle and placed in a staging/storage area. The containers are visually examined, labeled, logged, recorded, and sent to inspection and assay.

The purpose of the inspect/assay unit operation is to physically and radiologically characterize the waste to allow segregation of the containers. Based on the inspection and assay results, the waste containers are grouped according to their processing needs. The inspection and assay unit operation also identifies a special waste category that applies to any containerized waste requiring special processing operations.

The receiving and uncading area is equipped with a 20-ton bridge crane and a 5-ton forklift truck. It is designed to receive and unload containers from flat-bed trailers or van trucks. Containers brought in large overpacks [e.g., transportation package (TRUPAC II type containers)] can also be unloaded.

\subsection{Technical Bases and Assumptions}

\subsubsection{Functional and Operational Description}

Transportation vehicles are used to ship the containers (in overpacks if necessary) from the generators to the receiving and inspection facility. These vehicles are not included in the cost module. In the unloading and staging unit operation the transportation vehicles are unloaded, and containers are placed in the staging area. Surge storage is also provided. Containers may be moved within the unloading, staging, and surge storage areas and transported to and from the various interfacing unit operations.

Containers are unloaded in an enclosed truck bay and placed in an indoor staging area. The area is large enough to maneuver the containers and provide sufficient surge s:orage capacity to meet the desired operational reliability.

The assay/inspect unit operation is used to determine radioactivity, physical properties, and other parameters that are needed to categorize the containerized waste before processing, and in accordance with the criteria established for the processing unit operations. Various devices, such as 
passive/active neutron (PAN) counting instruments, may be used. Containers holding waste classified as other than LLW/LLMW or alpha-LLW/LLMW are returned to the generator.

Waste containers are also examined to allow classification by gamma radioactivity (in accordance with the criteria established for the processing unit operations) and to ensure that they are suitable for contact handling (less than $200 \mathrm{mRem} / \mathrm{h}$ on surface) and for treatment by the given process units. Various devices, such as Segmented Gamma Scan (SGS) instruments, may be used. Containerized wastes that do not meet the criteria are either handled as special waste or returned to the generator.

After the containers are examined, they are weighed and measured to determine waste density. Contents (such as metals, paper, glass, sludge, gas cylinders, and liquids) are determined by nondestructive examination. At a minimum, each container is examined using a nondestructive assay equipped with a real-time radiography (RTR) device. Ultrasonic devices are also used. After examination, each container is labeled, and the properties of its contents are logged and entered into a computerized database.

To allow year-round operations and to minimize the effects of a potential spill, it is assumed that the unloading and staging operations will take place indoors.

\subsubsection{Facility Integration}

In addition to general interfaces typical for all facilities, wastes from the generator facilities become input to the receiving/inspection facility. O\&M consumables, including personnel protective equipment, must be purchased. Facility output is the LLW/LLMW or alpha-LLW/LLMW containers that are transported to the open, dump, and sort facility or to treatment facilities.

\subsection{Cost Bases, Assumptions, and Assessments}

The general bases and assumptions for the cost estimate are presented in Appendix A. Facility specific items are discussed below.

- Major equipment capital cost items for this facility include alpha assay, gamma assay, a 20-ton bridge crane, and RTR units.

- Estimated operating staff is shown below in Table 3-1.

Table 3-1. Estimated operating staff for front-end receiving and inspection facility (cost module B).

\begin{tabular}{|c|c|c|c|c|}
\hline Unit operation & Description & Small & Medium & Large \\
\hline B-1 & Unloading, staging and storage & 4 & 10 & 24 \\
\hline \multirow[t]{2}{*}{ B-2 } & Inspect and assay & $\underline{2}$ & $\underline{8}$ & $\underline{24}$ \\
\hline & Total & 6 & 18 & 48 \\
\hline
\end{tabular}


- The crane cost is based on vendor quotations. The inspection and assay units are based on conceptual designs and cost estimates for a radiological and hazardous material measurement system (RHMMS) provided by EG\&G Iduho. Budget estimate for inspection and assay system is $\$ 2.0$ million.

- Small, medium, and large facility capacities and unit costs are shown in Table 3-2.

\subsection{Cost Summaries}

Cost summaries for receiving and inspection are shown in Table 3-3. A histogram of cost versus capacity is given in Figure 3-1.

Table 3-2. Capacity and cost information for treatment receiving and inspection facility (cost module B). ${ }^{a}$

\begin{tabular}{|c|c|c|c|c|c|c|c|c|}
\hline Mod. & Module & Facility & Life Cycle Cost & Capacity & Unit Cost & Capacity & Cap(Tot Vol) & Unit Cost \\
\hline & Description & & $(\$ \times 1000)$ & $(\mathrm{lbs} / \mathrm{hr})$ & $(\$ / / b)$ & $(f t 3 / h r)$ & $(f t 3 \times 1000)$ & $(\$ / \mathrm{ft} 3)$ \\
\hline & & & & & & & & \\
\hline & a & Small & $\$ 62,612$ & 200 & $\$ 3.88$ & 6 & 461 & $\$ 135.88$ \\
\hline & nt Rec. & Medium & $\$ 128,900$ & 5,600 & $\$ 0.29$ & 160 & 12,902 & $\$ 9.99$ \\
\hline & Treatment Rec./Insp. & Large & $\$ 204,179$ & 12,500 & $\$ 0.20$ & 357 & 28,800 & $\$ 7.09$ \\
\hline
\end{tabular}

a. Average density used is $35 \mathrm{lbs} / \mathrm{ft}^{3}$ 
Table 3-3. PLCC estimate summary for treatment receiving/inspection facility (cost module B).

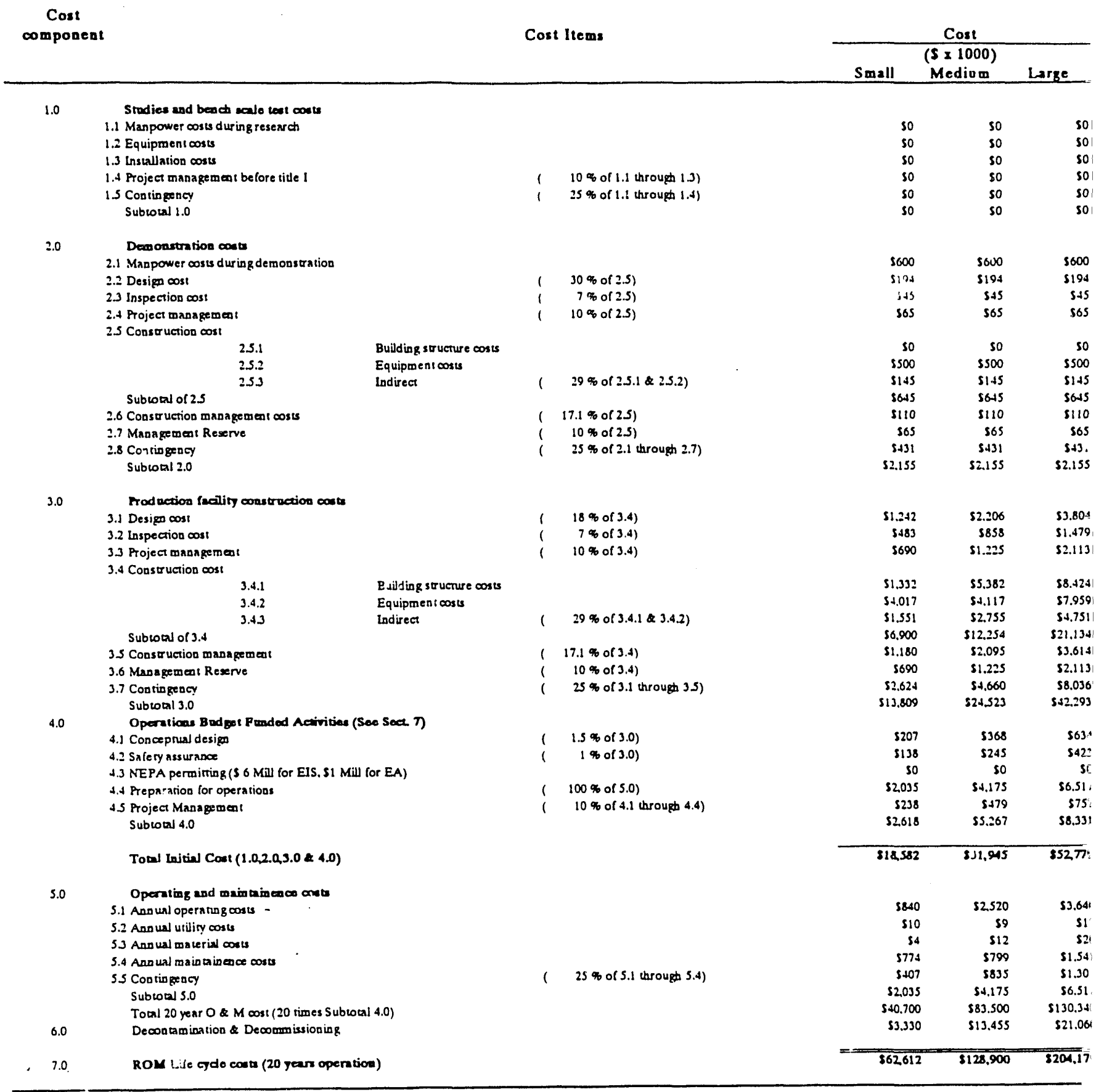




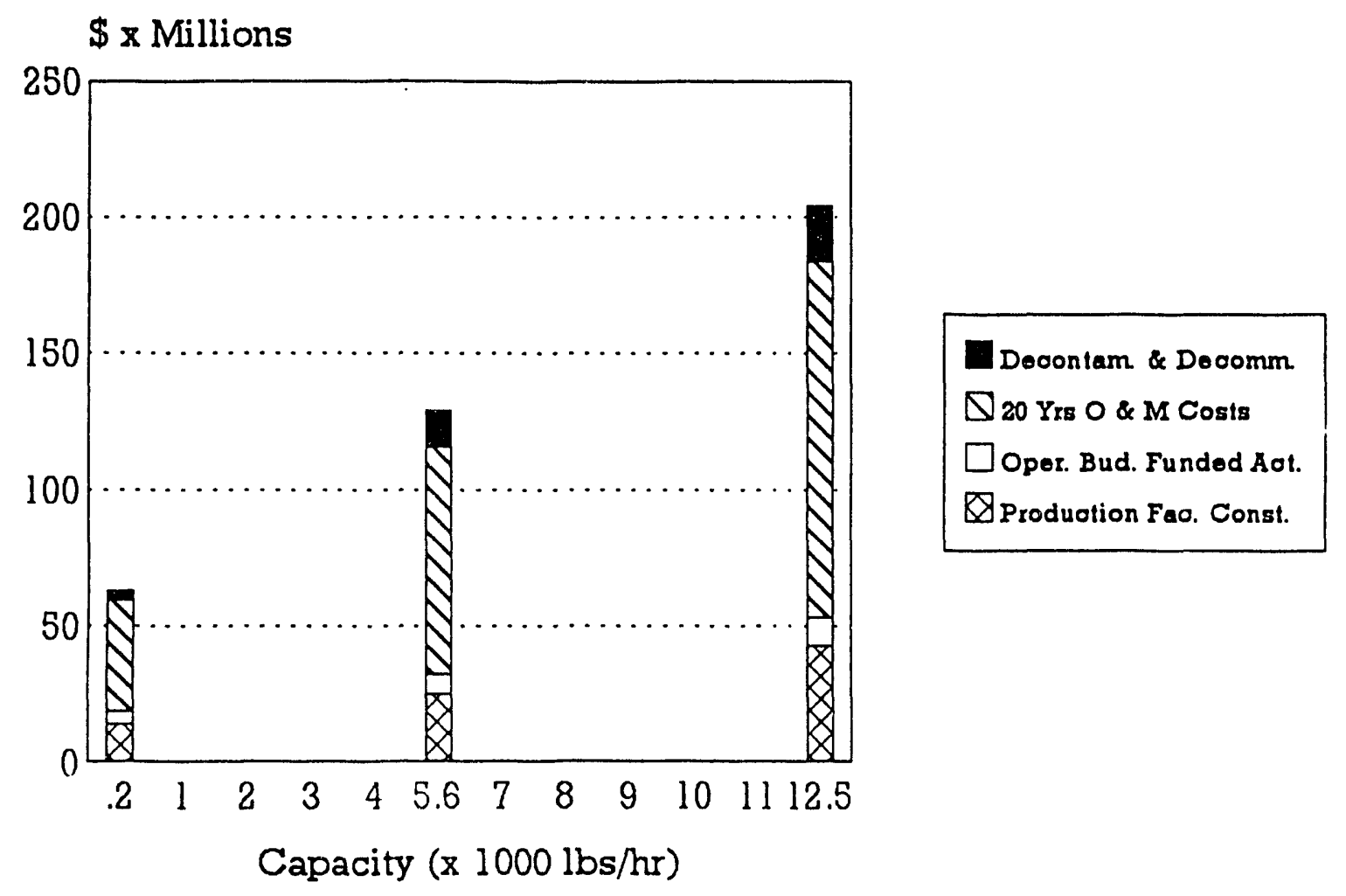

Figure 3-1. Cost versus capacity histogram for treatment receiving and inspection facility. 


\section{CONTAINER OPEN, DUMP, AND SORT FACILITY (COST MODULES CL AND CA)}

\subsection{Basic Information}

The open, dump, and sort facility, shown in Figure 4-1, is designed to be contiguous with the treatment facilities and is ideal for use with an integrated waste management facility that requires multitreatment streams. The facility opens and dumps the incoming waste containers and segregates the waste so that it can be fed to a combination of incineration, vitrification, solidification (or shredding compaction), and metal melting treatment processes. The facility handles the wastes in drums, boxes, or metal bins that are assumed to be properly characterized before they are opened. The facility is not needed if the waste arrives presorted. Cost module CL is applicable to LLW/LLMW while cost module CA is intended for alpha LLW/LLMW. Unit operations are given in Figure 4-2.

The facility also has the capability to reduce the size of empty, nonmetal containers. Metal containers, however, must be transported to other facilities for handling (such as a decontamination facility for washdown and reuse and/or a metal melting facility for processing).

\subsection{Technical Bases and Assumptions}

\subsubsection{Functional and Operational Description}

At the open, dump, and sort facility the waste containers are decapped, and the waste is dumped either onto sorting devices or into transport bins that carry the waste to the treatment operations.

LLW/LLMW container opening is done manually while alpha-LLW/LLMW container opening is done by remote means. Both LLW/LLMW and alpha-LLW/LLMW container dumping and sorting operations are accomplished remotely by manipulators and robots housed in a cubicle that has a controlled environment and multiple barriers. Adequate hoods and supporting ventilation are provided to minimize the spread of dust and contamination. Alpha-LLW/LLMW operations are accomplished in an alpha cell where containers enter the cell through airlock doors. Equipment maintenance is accomplished manually in a controlled environment. In addition, the equipment can be pulled out and decontaminated before performing maintenance.

After the waste containers enter the controlled cubicle environment through airlock doors, they are grouped according to two categories: those that must only be opened and dumped, and those that require open, dump, and sort operations. After container caps are removed, the waste in the containers of the first category are dumped into bins that directly transport it to the treatment facilities. 


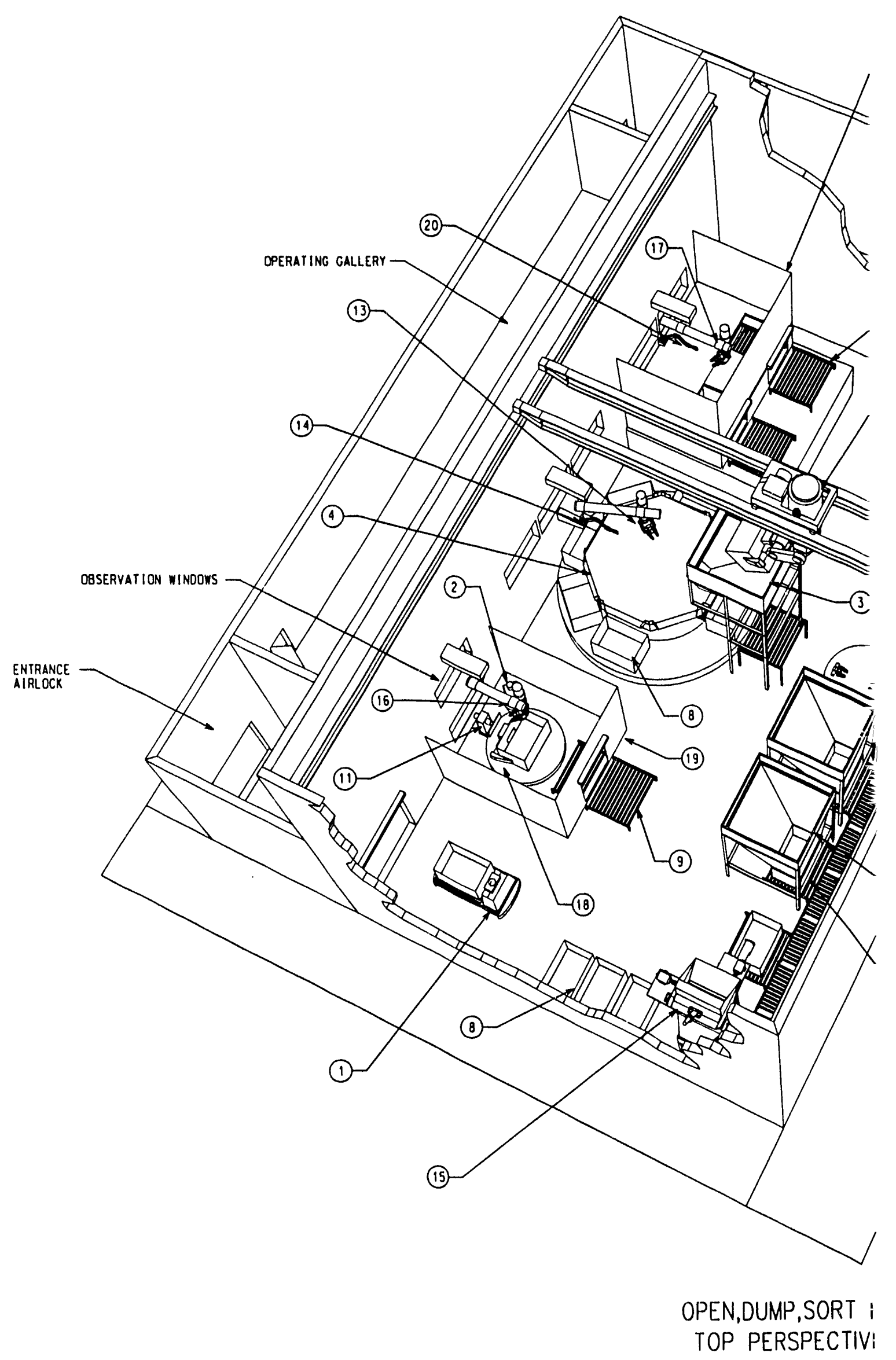

Figure 4-1. Typical arrangement for alpha-LLW/LLMW open, dump, and sort facility. 
(5)

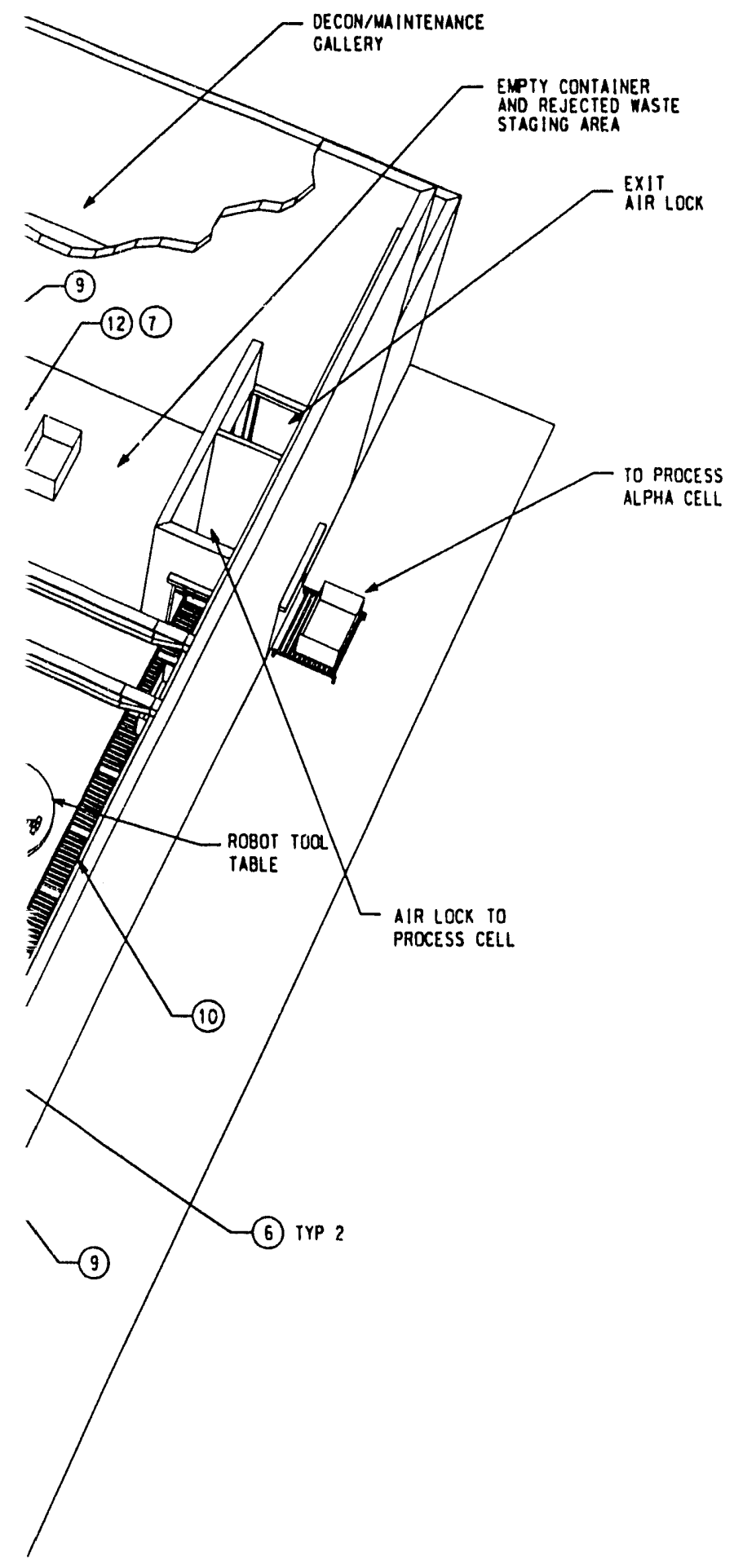

\section{MAJOR EQUIPMENT LIST}

(1) SELF GUIDED VEHICLE

(2) DE-CAP DEVICE

(3) SORT HOPPER

(4) SORT TABLE/ROTATING TABLE

(5) SPECIAL MaSTE gLOVEBOX

(6) DUMP HOPPER

(7) maintenance crane

(8) gins $4\left(4^{\prime} \times 4^{\prime} \times 6^{\prime}\right)$

(9) BIN CONVEYORS $8^{\prime}$ LONG

(10) BIN CONVEYOR $70^{\prime}$ LONG

(11) BIN PUSHER

(12) MAIN CELL CaNtRY ROBOt

(13) Sorting table hyoraulic manipulator

(14) SORTING master slave manipulator

(15) BOX SIZE REDUCTION UNIT

(16) DRUN OPENING GANTRY ROBOT

(17) glovebox hyoraulic manipulator

(18) CONIAINER GaPPLER

(19) decap enclosure

(20) Glovebox master slave manipulator

ACILITY

VIEW 


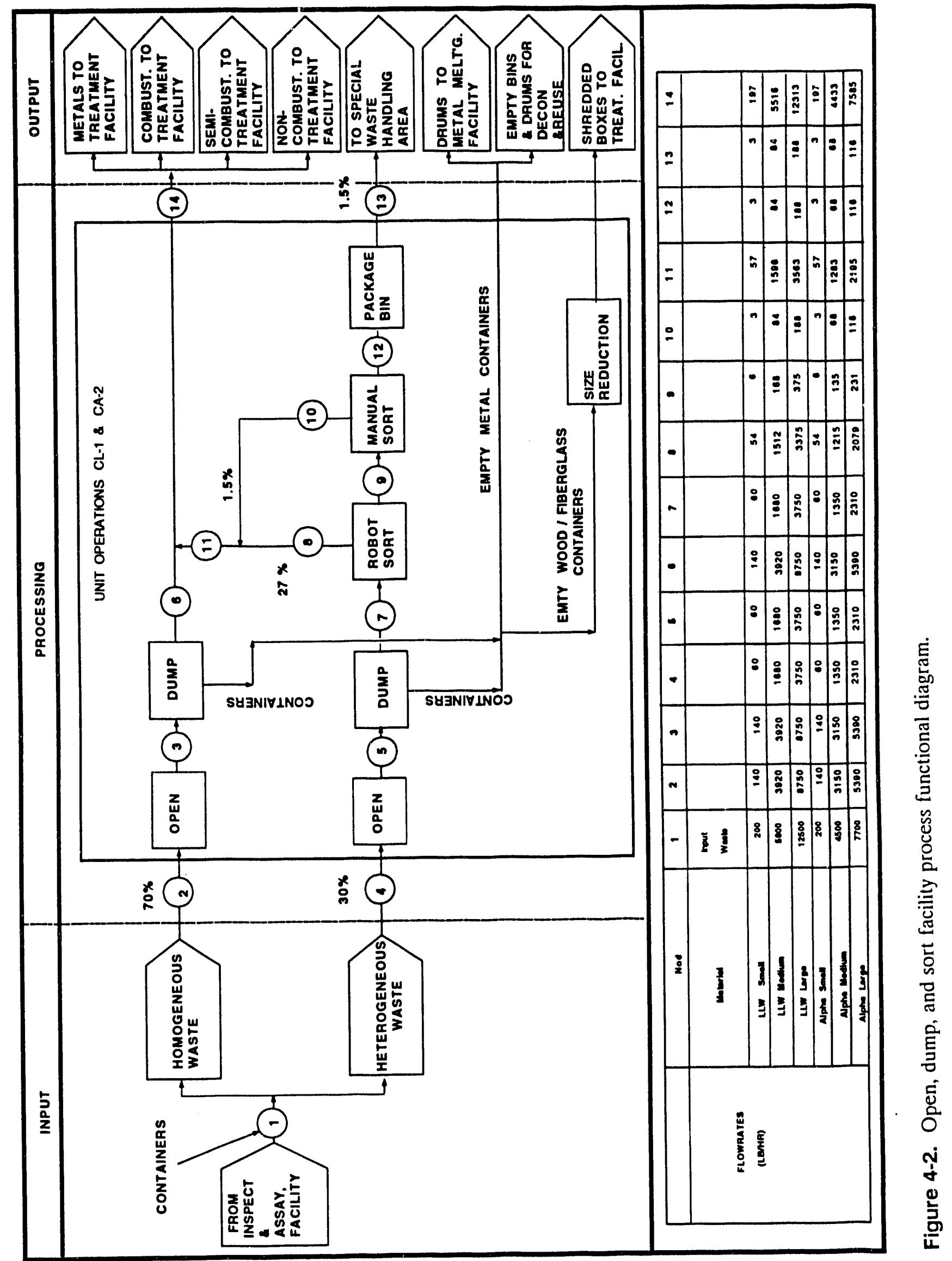


The waste in the containers that are designated for segregation is dumped onto a sorting station, which removes bulk metals, noncombustibles, semicombustibles, combustibles, special wastes, ${ }^{c}$ and gas cylinders. Various sorting technologies, such as robotic assisted sort tables, vibratory screens, and air classifiers, may be used in the sorting station. Any spilled liquid is collected and sent to other unit operations for treatment. The sorted waste materials are placed into transfer bins and transferred to the treatment facilities. Nonmetallic containers are cut into smaller pieces as required for processing.

\subsubsection{Facility Integration}

In addition to general interfaces for all facilities, input interfaces to the open, dump, and sort facility are waste containers from the receiving/inspection facility. O\&M consumables including personnel protective equipment are purchased. Output interfaces include sorted LLW/LLMW or alpha-LLW/LLMW solid waste to treatment. Also, reusable empty metal drums and boxes are sent to a decontamination fauility for cleaning and recycle.

\subsection{Cost Bases, Assumptions, and Assessments}

General cost bases and assumptions are given in Appendix A. Facility specific items are discussed below.

- Estimated operating staff is shown below in Table 4-1.

Table 4-1. Estimated operating staff for open, dump, and sort facility (cost module CL and CA).

\begin{tabular}{lcccc}
\hline & $\begin{array}{c}\text { Small } \\
\text { (LLM/LLMW) } \\
\text { and alpha- } \\
\text { (LLM/LLMW) }\end{array}$ & $\begin{array}{c}\text { Medium } \\
\text { (LLM/LLMW) } \\
\text { and alpha- } \\
\text { (LLM/LLMW) }\end{array}$ & $\begin{array}{c}\text { Large } \\
\text { (LLW/LLMW) }\end{array}$ & $\begin{array}{c}\text { Large } \\
\text { alpha- } \\
\text { (LLW/LLMW) }\end{array}$ \\
\hline 1. Sorting table & 8 & 32 & 128 & 96 \\
2. Glovebox & 4 & 4 & 16 & 12 \\
3. Oven \\
$\begin{array}{l}\text { container } \\
\text { Gantry robot } \\
\text { (transport and } \\
\text { dump bins) }\end{array}$
\end{tabular}

c. Special wastes are those materials that are not compatible with the treatment techniques provided in the facility (e.g., mercury). After identification and removal, special wastes are treated by mobile units provided on a case-by-case basis. 
- Major equipment capital cost items for this cost modile are container open, dump, and sort devices and robotics arms. The costs for these items are developed based on consultation with personnel from DOE contractors invilved in the Office of Technology Development, Robotic Technology Development Program.

- Small, medium, and large facility capacities and unit costs are shown in Table 4-2.

\subsection{Cost Summaries}

Cost summaries for the LLW/LLMW and alpha-LLW/LLMW open, dump, and sort facilities are shown in Tables 4-3 and 4-4. A histogram of cost versus capacity is given in Figures 4-3 and 4-4.

Table 4-2. Capacities and cost information for open, dump, and sort facility (cost modules CL and CA).

\begin{tabular}{|c|c|c|c|c|c|c|c|c|}
\hline Mod. & Module & Facility & Life Cycle Cos & Capacity & Unit Cost & Capacity & Cap(Tot Vol) & Unit Cost \\
\hline & Description & & $(\$ \times 1000)$ & (lbs/hr) & $(\$ / / b)$ & $(\mathrm{ft} 3 / \mathrm{hr})$ & $(f+3 \times 1000)$ & $(\$ / f t 3)$ \\
\hline & & & & & & & & \\
\hline$C L$ & Front-end Treatment & Small & $\$ 170,095$ & 200 & $\$ 10.55$ & 6 & 461 & $\$ 369.1$ \\
\hline $\mathrm{CL}$ & Front-end Treatment & Medium & $\$ 689,326$ & 5,600 & $\$ 1.53$ & 160 & 12,902 & $\$ 53.43$ \\
\hline $\mathrm{CL}$ & Front-end Treatment & Large & $\$ 1,522,432$ & 12,500 & $\$ 1.51$ & 357 & 28,800 & $\$ 52.86$ \\
\hline $\mathrm{CA}$ & Front-end Treatment & Smaill & $\$ 216,026$ & 200 & $\$ 13.39$ & 6 & 461 & $\$ 468.81$ \\
\hline $\mathrm{CA}$ & Front-end Treatment & Medium & $\$ 1,182,462$ & 4,500 & $\$ 3.26$ & 129 & 10,368 & $\$ 114.05$ \\
\hline $\mathrm{CA}$ & Front-end Treatment & Large & $\$ 1,419,910$ & 7,700 & $\$ 2.29$ & 220 & 17,741 & $\$ 80.04$ \\
\hline
\end{tabular}

a. Average density used is $35 \mathrm{lbs} / \mathrm{ft}^{3}$ 
Table 4-3. PLCC estimate summary for LLW/LLMW treatment open, dump, and sort facility (cost module $\mathrm{CL}$ ).

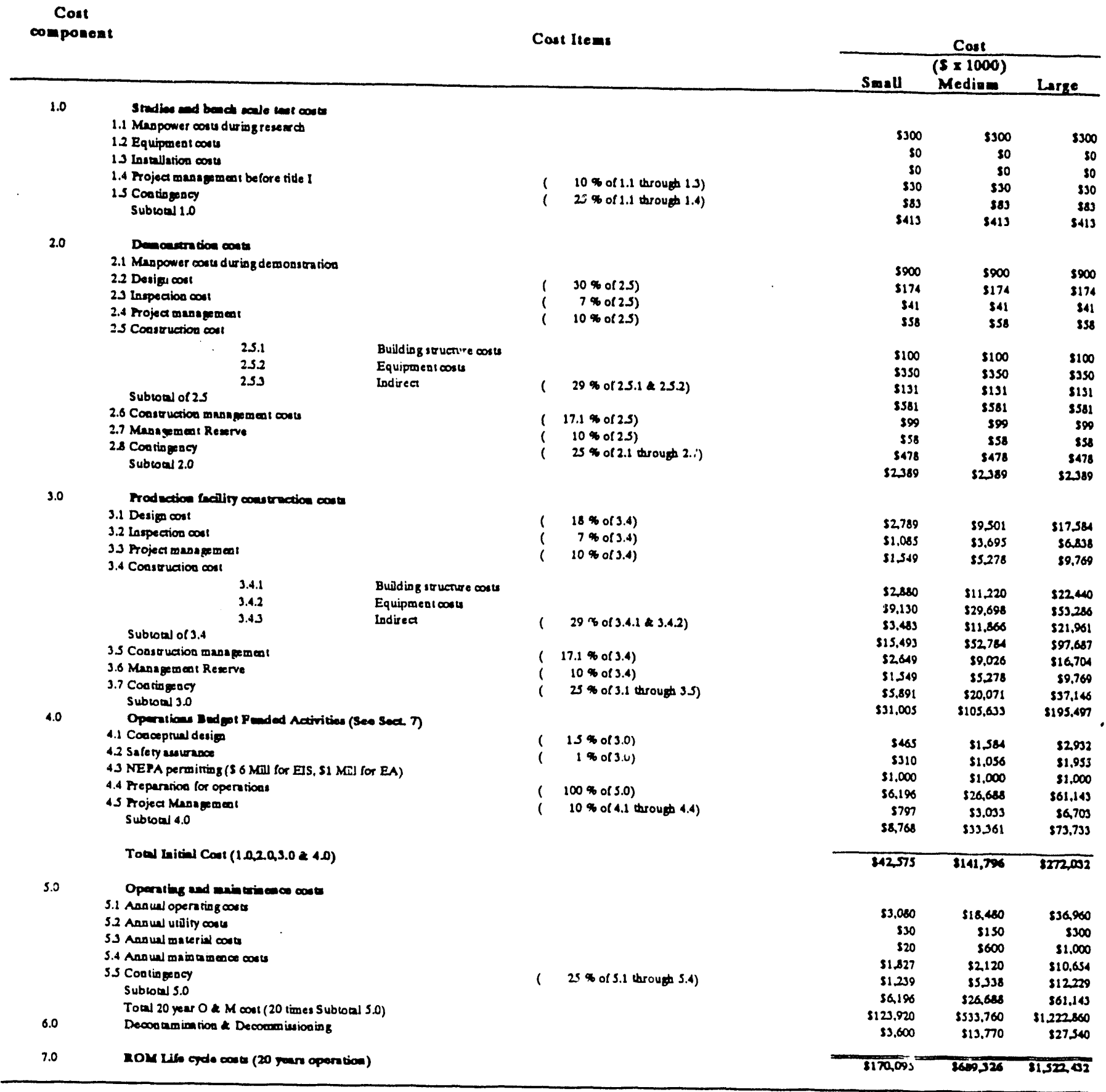


Table 4-4. PLCC estimate summary for alpha-LLW/LLMW treatment open, dump, and sort facility (cost module CA).

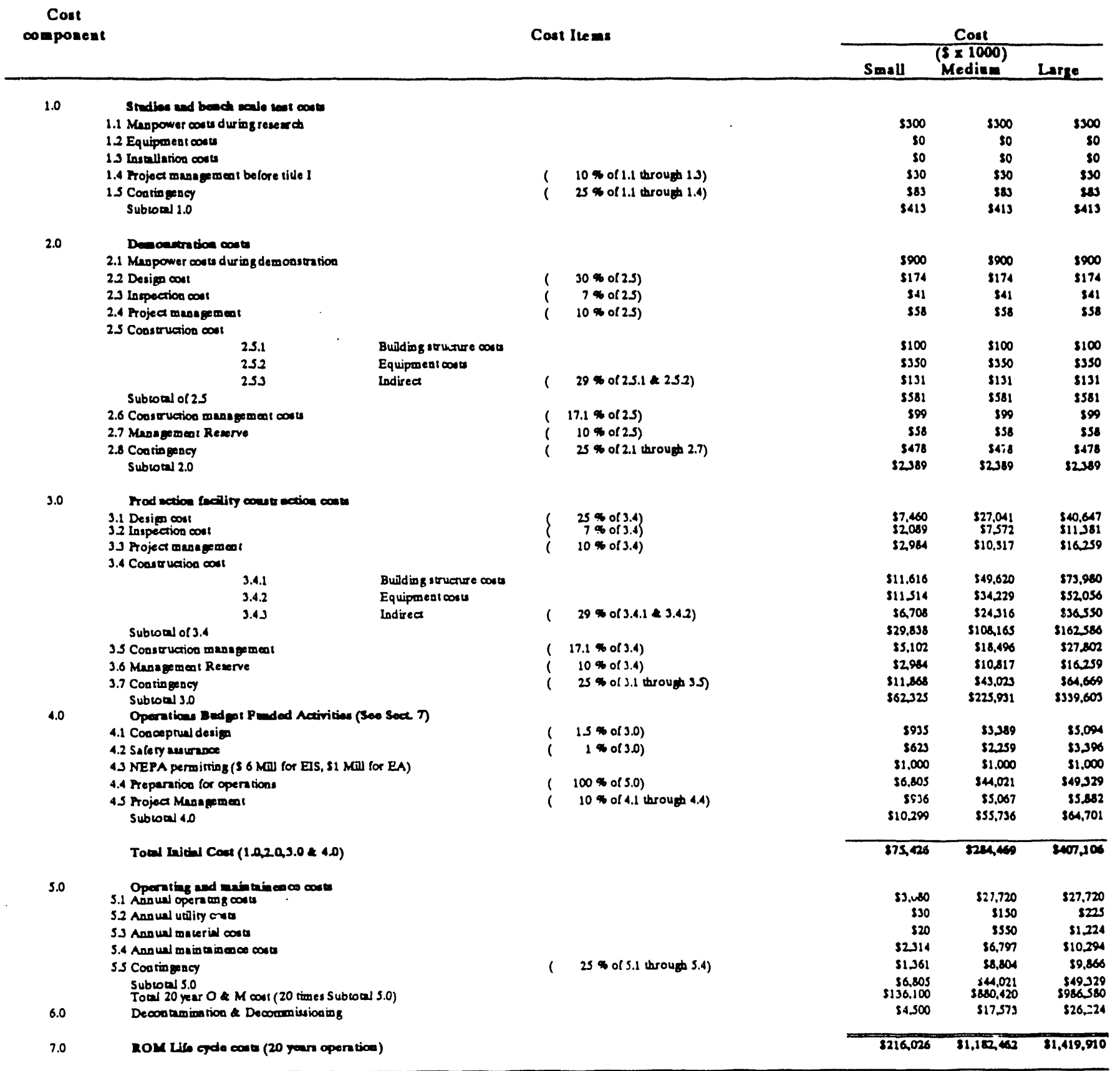




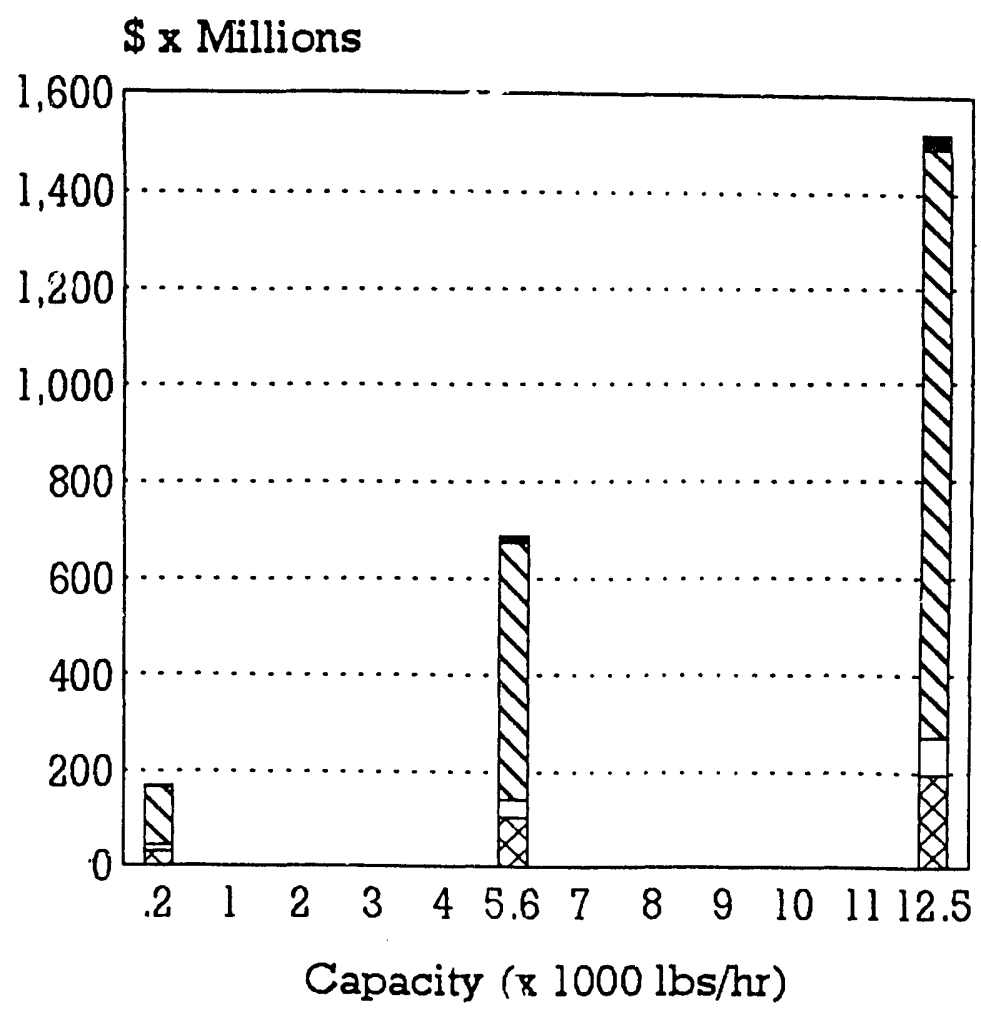

Decontam \& Decomm. D20 Yrs O \& M Costs Oper. Bud. Funded Act. Bproduation Fao. Const.

Figure 4-3. Cost versus capacity histogram for LLW/LLMW treatment open, dump, and sort facility (cost module $\mathrm{CL}$ ).

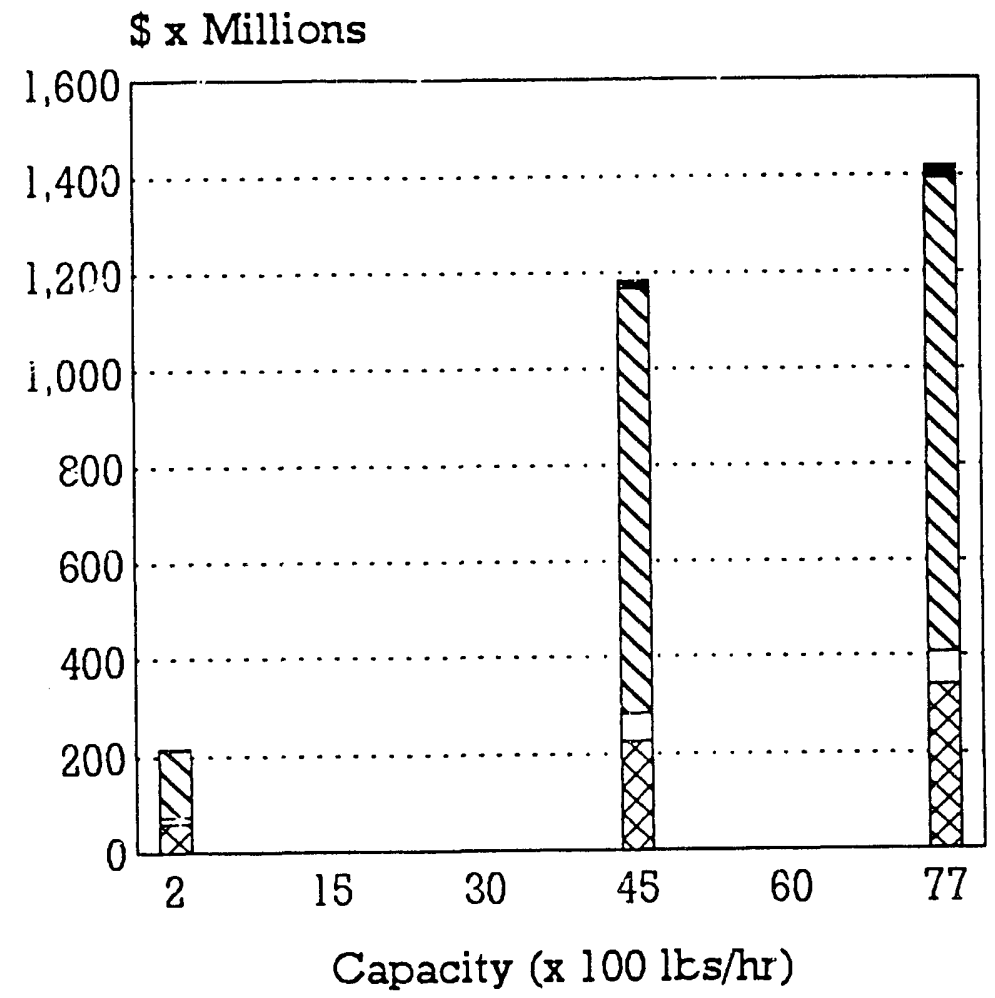

Decontam \& Decomm. $\nabla_{20}$ Yrs $O \&$ M Costs $\square$ Oper. Bud. Funded Act. $\triangle$ production Fac. Const.

Figure 4-4. Cost versus capacity histogram for alpha-LLW/LLMW treatment open, dump, and sort facility (cost module CA). 


\section{INCINERATION FACILITY (COST MODULES DL AND DA)}

\subsection{Basic Information}

The incineration facility, shown in Figure 5-1, must be either used in conjunction with the frontend and back-end support facilities (see cost modules A, B, CA/CL, I, and JA/JL) or constructed next to existing facilities where similar functions are already available. The incineration incorporates nine major unit operations that process and package either LLW/LLMW or alpha-LLW/LLMW. The process incinerates waste and solidifies the resulting ash, thus converting the waste into a form that complies with land disposal restrictions (LDR) requirements (refer to Appendix A). Cost module DA is applicable to alpha-LLW/LLMW, while cost module DL is for LLW/LLMW. Unit operations are shown in Figure 5-2.

The faciiity is designed to treat combustible solid waste, noncombustible solid waste that is mixed with combustible (semicombustible) solid waste, inorganic and organic liquid waste, and organic sludge. These categories are defined in Appendix A. When used for semicombustible solids, the resultant ash must not be more than $15 \%$ of the input waste by weight. If the ash weight exceeds $15 \%$, cost adjustments must be made for larger ash handling and solidification units. If inorganic liquid waste feed is considered, up to $15 \%$ of the incoming waste feed rate can be incorporated without adjusting the costs for a higher thermal capacity burner.

The facility is based on costs and layout for either a stationary or rotary kiln incinerator. Rotary kiln designs are preferable if a significant portion of the feed is organic-contaminated solids (such as soil).

\subsection{Technical Bases and Assumptions}

\subsubsection{Functional and Operational Description}

The sorted waste enters the facility and is fed to the incinerator via an input preparation and feed unit, where the material is crushed and shredded. All combustible materials are thermally destroyed while inert materials pass through with the ash. In the solidification feed and preparation unit operation, the ash discharged from the incineration unit is collected, cooled, and stored. Upon demand, the ash is transported to a solidification unit, where it is mixed with plant wastewater and a binder (such as Portland cement) at a predetermined ratio to produce a stabilized waste form. After the components are properly mixed, the mixture is poured into disposal containers. The filled containers are capped and sent through a wash unit operation, where the drums are sealed and then washed by a high-pressure water spray. The containerized waste is ready for processing through radioassay and final certification, which are part of the back-end support facility.

The incineration facility generates two secondary waste streams: liquid and off-gas. The incinerator off-gas treatment unit is equipped with a secondary combustion unit that destroys the volatile organics. The secondary combustion effluent is fed to air pollution control devices designed to remove particulates, $\mathrm{SO}_{2}, \mathrm{HCl}$, and NOx. A surge tank retains off-gas for reprocessing in the event of a process upset. Secondary liquid waste is processed through a treatment unit, where dissolved and suspended solids (organic and inorganic) are removed. Treated wastewater is recycled 
for reuse. Sludge and other wet solids are fed into either the incinerator or the solidification unit for processing.

The anticipated net weight reduction for the input waste is approximately $50 \%$ based on the assumption that the treatment facility is a zero-discharge site. The anticipated density of the solidified waste is $112 \mathrm{lbs} / \mathrm{ft}^{3}$. In addition, the incineration cost module will meet the following performance requirements:

- Input Waste: The facility can receive diverse types of waste material. The incinerators are sized based on 7,000 Btu/lb of incoming waste. At a minimum, the facility will process combustible and semicombustible solids, organic sludge, and organic and inorganic liquids.

- $\quad$ Output Waste: The solidified LLW/LLMW waste produced by incineration is suitable for disposal in an engineered as shallow land burial site. The suitability of engineered as shallow land disposal for alpha-LLW/LLMW requires further investigation.

- Efficiency: The system minimizes the volume of waste that requires disposal and the quantity of secondary waste and other discharges to the environment.

\subsubsection{Facility Integration}

Facility input interfaces include waste from the open, dump, and sort facility. Purchased materials include consumables such as personnel protective equipment, laboratory material, solidification materials, packaging materials, and disposable and reusable shipping containers.

The output interface consists of packaged LLW/LLMW or alpha-LLW/LLMW drums transported to the back-end facility. Scrubbed exhaust gases are discharged to the atmosphere.

\subsection{Cost Bases, Assumptions, and Assessments}

General cost bases and assumptions are given in Appendix A. Facility-specific items are discussed below.

- The incinerator, off-gas, and solidification units constitute the major equipment capital cost items. Incinerator prices are based on vendor bids for both rotary-kiln and stationary (controlled air) incinerators. Similar bids obtained for the off-gas and solidification units and the cost of the TSCA incinerator at ORNL were also considered in developing estimates.

- Major equipment capital costs are verified against the purchased costs at a commercial LLW incineration facility (SEG facility in Oak Ridge). The alpha-LLW incinerator is verified against the cost estimates contained in the EG\&G Idaho SWSDS. ${ }^{2}$

- $\quad$ Estimated operating staff is shown in Table 5-1.

- Small, medium, and large facility capacities and unit costs are shown in Table 5-2. 


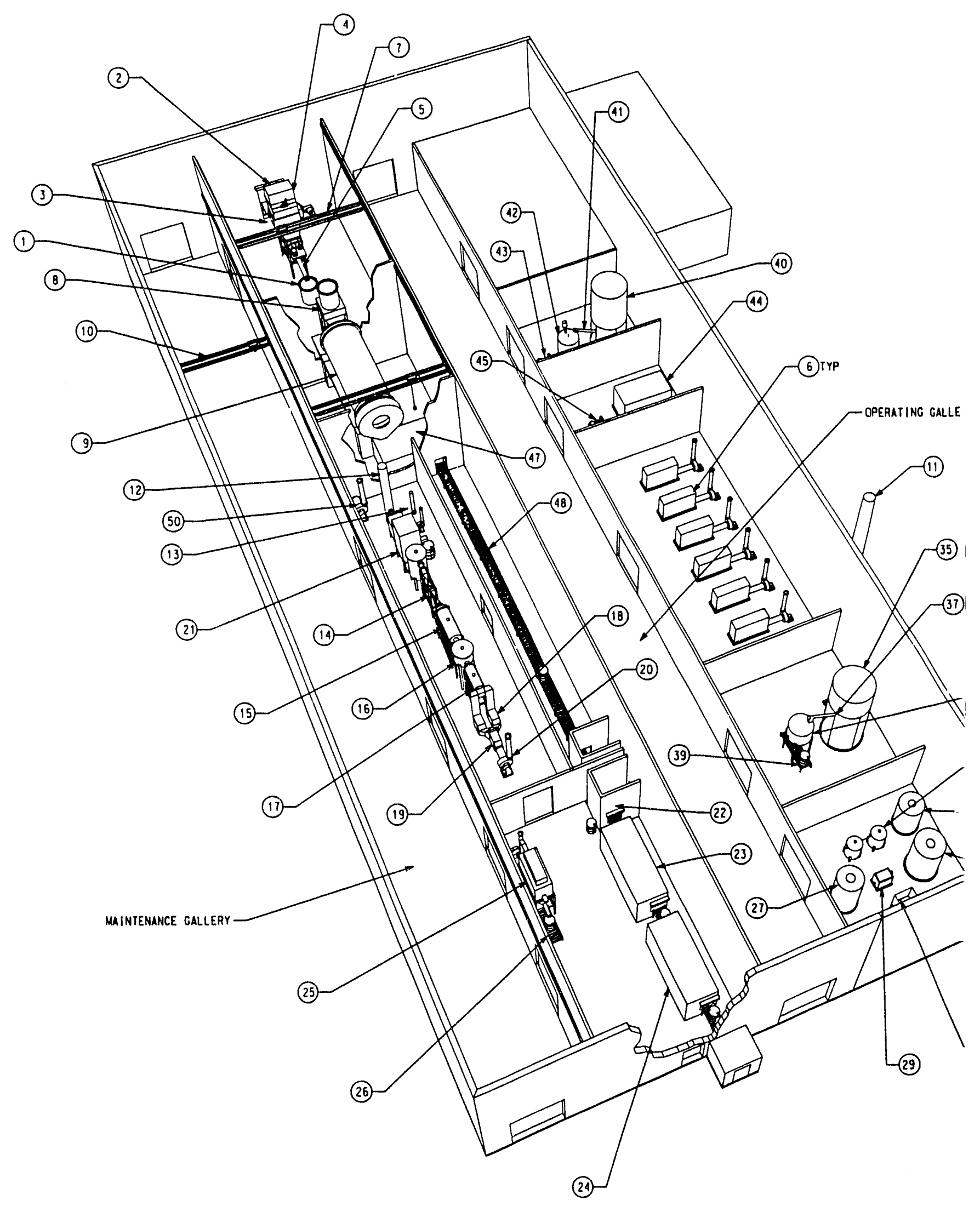

INCINERATION FACII TOP PERSPECTIVE

Figure 5-1. Typical arrangement for alpha-LLW/LLMW incineration facility. 


\section{MAJOR EQUIPMENT LIST}
(1) Taste transfer bin
(2) InCOMIng maste BIN
(3) BIN HOLST
(4) SHREDDER (2) WITH FEED HOPPER. DUST HOOO
(5) ANGEER FEEDER
(6) HEPA FILTER ANO FAN
(7) underhung crane in ENClosed process area
(8) FEED BIN
(9) incinerator
(10) unoerhung crane in EnClosed
ma intenance area
(11) STACK
(12) AF TERBURNer
(13) GAS COOER
(14) DOUBLE VENTURI
(15) CONDENSER
(16) MIST ELIMINATOR
(17) Reheater
(18) Double hePa FILTERS
(19) FIMAL HEPA FILTER
(20) 1.D. FAN
(21) CERAMIC aAs FILTER
(22) DRUM STAGING CONVEYOR (POMERED ROLL)
(23) SOLIDIFICATION SYSTEM
(24) DRUM CAPPING AND MASHING SYSTEM
(25) DUSt COLLECTOR. fan AND hePA FILTER
(26) ORUM STAGING CONVEYOR (POMERED ROLL)
(27) RECEIVING TANK
(28) PUIP
(29) FILTER
(30) ION EXCHANGE
(31) tREATED waste tanK
(32) PUMP
(33) SLUDCE TANK
(34) PUMP
(35) Storage silo
(36) BIN HOIST
(37) COMVEYR
(38) DAY BIN
(39) DRUM STAGING CONYEYOR (GRAVITY)
(40) LIME SILO
(41) SCRE CONYEYOR
(42) MIXING TANK N/MIXER
(43) FEED PUIP
(44) COOLING SYSTEM
(45) CIRC. PUIN
(46) DRUM STAGING CONVEYOR (POMERED ROLL)
(17) ASH HOPPER ANO CONVEYOR
(48) DRUM STAGING CONVEYOR (POMERED ROL)
(49) PRECipitation tank
50) InCINERATOR AIR SUPPLY fan 


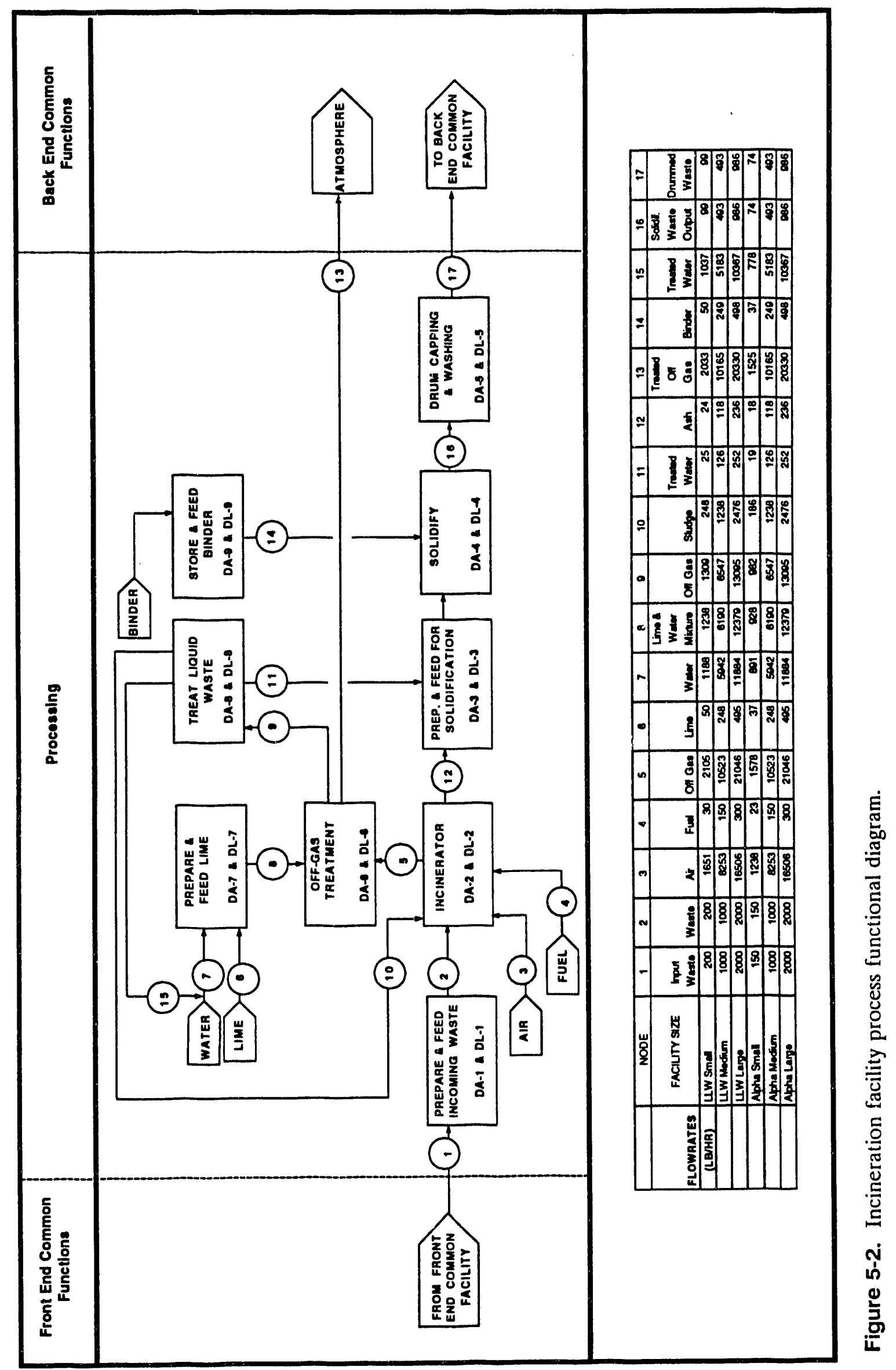


Table 5-1. Estimated operating staff for incineration facility (cost module D).

\begin{tabular}{clccc}
\hline $\begin{array}{c}\text { Unit } \\
\text { operation }\end{array}$ & \multicolumn{1}{c}{ Description } & $\begin{array}{c}\text { Small } \\
\text { (FTE) }\end{array}$ & $\begin{array}{c}\text { Medium } \\
\text { (FTE) }\end{array}$ & $\begin{array}{c}\text { Large } \\
\text { (FTE) }\end{array}$ \\
\hline D-1 & Prepare and feed incoming waste & 10 & 13 & 19 \\
D-2 & Incinerator & 10 & 13 & 16 \\
D-3 & Prepare and feed for solidification & 2 & 4 & 4 \\
D-4 & Solidify & 2 & 4 & 7 \\
D-5 & Drum capping and washing & 0 & 0 & 0 \\
D-6 & Off-gas treatment & 2 & 4 & 4 \\
D-7 & Prepare and feed lime & 2 & 2 & 4 \\
D-8 & Treat liquid waste & 4 & 4 & 4 \\
D-9 & Store and feed binder & 2 & 4 & 4 \\
D-10 & Electrical distribution and Motor & 1 & 2 & 4 \\
& Control Center & & & 4 \\
D-11 & Heating, ventilation, and exhaust & 2 & 4 & 14 \\
D-12 & Other equipment & $\underline{6}$ & 10 & 84 \\
& Total & 43 & 64 & 4 \\
\hline
\end{tabular}

Table 5-2. Capacities and costs information for incineration facility (cost module DL and DA). ${ }^{\mathrm{a}}$

\begin{tabular}{|c|c|c|c|c|c|c|c|c|}
\hline Mod. & Module & Facility & Life Cycle Cost & Capacity & Unit Cost & Capacity & Cap(Tot Vol) & Unit Cost \\
\hline & Description & & $(\$ \times 1000)$ & $(\mathrm{lbs} / \mathrm{hr})$ & $(\$ / 1 b)$ & $(f+3 / h r)$ & $(f t 3 \times 1000)$ & $(\$ / f t 3)$ \\
\hline $\mathrm{DL}$ & Incinoration & Small & 245 & ? & 01007 & 6 & 101 & 56128 \\
\hline $\mathrm{DL}$ & Incineration & Medium & $\$ 453292$ & 1000 & $\$ 5.62$ & 29 & 2304 & $\begin{array}{l}\$ 196.74 \\
\end{array}$ \\
\hline DL & Incineration & Large & $\$ 624,390$ & 2,000 & $\$ 3.87$ & 57 & 4,608 & $\$ 135.50$ \\
\hline $\mathrm{DA}$ & Incineration & Small & $\$ 364,684$ & 150 & $\$ 30.15$ & 4 & 346 & $\$ 1,055.22$ \\
\hline $\mathrm{DA}$ & Incineration & Medium & $\$ 536,989$ & 1,000 & $\$ 6.66$ & 29 & 2,304 & $\$ 233.07$ \\
\hline $\mathrm{DA}$ & Incineration & Large & $\$ 732,819$ & 2,000 & $\$ 4.54$ & 57 & 4,608 & $\$ 159.03$ \\
\hline
\end{tabular}

a. Average density used is $35 \mathrm{lbs} / \mathrm{ft}^{3}{ }^{3}$

\subsection{Cost Summaries}

Cost summaries for the LLW/LLMW and alpha-LLW/LLMW incineration cost modules are shown in Tables 5-3 and 5-4. Histograms for cost versus capacity are given in Figures 5-3 and 5-4. 
Table 5-3. PLCC estimate summary for LLW/LLMW incineration facility (cost module DL).

Cost

component Cost Items
Cost

\begin{tabular}{c} 
Cost \\
\hline Small $\begin{array}{c}(\$ \times 1000) \\
\text { Mediom }\end{array}$ Large \\
\hline
\end{tabular}

1.0

Strodies and beoch rove cost cones

1.1 Maspower costs during recearch

1.2 Equipment costs

1.3 Lastallation costs

is Conturigency

$10 \%$ of $(1.1$ through 1.3$)$

( $25 \%$ of 1.1 throuph 1.4)

Deronstrotion costs

2.0

2.1 Marapower cosus during demonsonation

2.2 Design cost

2.3 Inspection cost

2.4 Project managemen

25 Constrution cost

$\begin{array}{ll}2.5 .1 & \text { Buildiag strueture costs } \\ 2.5 .2 & \text { Equ:progricosts }\end{array}$

Subtotal of 2.5

2.6 Consuruction management costs

2.7 Maragement Reserve

2.8 Contingency

Subwal 2.0

Foduction facility constrection costs

3.1 Design cos

3.2 Inspection cos!

3.3 Project manngemen

3.4 Construction cost

3.4 .1
3.4 .2
3.4 .3

Subrotal of 3.4

3.5 Construction managetneat

3.6 Managemeni Reserve

3.7 Con riogency

Subwal 3.0

Oparations Bodgot Pended Aativitios (Soo Soct T)

4.1 Conceprual desiog

4.2 Safery assurance

4.3 NEPA permining (S 6 Mill for EIS, S1 Mill for EA)

1.4 Preparation for operations

4.S Project Management

Lnduear

$29 \%$ of $2.5 .1 * 2.5 .2)$

$(17.1 \%$ of 2.5$)$

$10 \%$ of 25$)$

25 क of 2.1 through 2.7)

$18 \%$ o( 3.4)

$7 \%$ o $(3.4)$

10 of 3.4 )

Building strueture osts

Equipment costs

Indireet

$(\quad 29 \%$ of $3.4 .1<3.4 .2)$

$(17.1 \%$ of 3.4$)$

( $10 \%$ of 3.4 )

( $25 \%$ of 3.1 throug 3.5 )

$(15 \%$ of 3.0$)$

$(1 \%$ of 3.0$)$

( $100 \%$ of 5.0$)$

( $10 \%$ of 4.1 ithrough 4.4)

Total tritial $\cos (1.0 .2 .0 .3 .0 \propto 4.0)$

Operating and main thimenco cont

51 Annual operatizgocats

5.2 Ann ual utility cos ts

S.3 Annual moncerial costs

5.4 Annual main tainence costs

S.S Contingency

Subrotyl 5.0

Total 20 year $O$ \& $M \operatorname{cosi}(20$ times Sublotal 5.0 )

6.0 Deconlamination \& Decomisesioning

7.0 ROW Lifo cyde conts (20 years oporation)
Small

Mediom

arge

$\$ 1.350 \quad \$ 1.350 \quad \$ 1.350$

$\$ 50 \quad \$ 50 \quad \$ 50$

S155 S15s \$15s

\$26 \$426 \$426

$\$ 2.400 \quad \$ 2.400 \quad \$ 2.400$

$\$ 360 \quad \$ 360 \quad \$ 360$

584584

$\$ 120 \quad \$ 120 \quad \$ 130$

$\$ 180 \quad \$ 180 \quad \$ 180$

$\$ 750 \quad 5750 \quad 5750$

$\$ 270 \quad \$ 270 \quad \$ 270$

$\$ 1.200 \quad s 1.200 \quad \$ 1.200$

$\$ 205 \quad s 205 \quad \$ 205$

$\$ 120 \quad \$ 120 \quad \$ 120$

$\$ 1.122 \quad \$ 1.122 \quad \$ 1.12$

$\$ 5.611 \quad \$ 5.611 \quad \$ 5.611$

$\$ 3.637 \quad \$ 5.826 \quad \$ 6.202$

$\$ 1.415 \quad \$ 1.877 \quad \$ 2.412$

$\$ 2.021 \quad \$ 2.681 \quad \$ 3.446$

$\$ 3.351 \quad 55.229 \quad 56.222$

$\$ 12314 \quad \$ 15.555 \quad \$ 20.490$

$\$ \$ \$ .543 \quad 56.027 \quad 57.746$

$\$ 20.208 \quad \$ 26.811 \quad \$ 34.458$

$\$ 3.456 \quad \$ \$ .585 \quad \$ 5.892$

$\$ 2.021 \quad \$ 2.081 \quad \$ 3,446$

$\$ 57.634 \quad \$ 10.195 \quad \$ 13.103$

$\$ \$ 0,442 \quad \$ 53,656 \quad \$ 68.959$

$\begin{array}{lll}5007 & 5805 & \$ 1.034\end{array}$

$\$ 404 \quad \$ 537 \quad \$ 690$

$\$ 6.000 \quad \$ 6.000 \quad \$ 6.000$

$\$ 11.200 \quad \$ 17.895 \quad \$ 25.198$

$\$ 1.821 \quad \$ 2.524 \quad \$ 3.292$

$\$ 20.032 \quad \$ 27.761 \quad \$ 36.214$

$\begin{array}{lll}868,216 & \$ 89,159 & \$ 112,915\end{array}$

$\$ 6.020 \quad \$ 8.960 \quad \$ 11.760$

$\begin{array}{rrr}\$ 3.020 & \$ 8.960 & \$ 11.760 \\ \$ 324 & \$ 1.889 & \$ 3.742\end{array}$

$\$ 136-\$ 323$

$\$ 2480 \quad \$ 3.144 \quad \$ 4.150$

$\$ 2240 \quad \$ 3.579 \quad \$ 5.040$

$\$ 11.200 \quad \$ 17.895 \quad \$ 25.198$

$\$ 224.000 \quad \$ 357.900 \quad \$ 503.960$

$\begin{array}{lll}\$ 4.029 & \$ 6.233 & \$ 7.515\end{array}$

$\begin{array}{lll}396245 & \$ 453,292 & \$ 624.390\end{array}$ 
Table 5-4. PLCC estimate summary for alpha-LLW/LLMW incineration facility (cost module DA).

Cost

component
Cost Items

$10 \%$ of 1.1 (through 1.3$)$

$25 \%$ of 1.1 (through 1.4)

$$
\begin{gathered}
7 \% \text { o( } 2.5) \\
10 \% \text { of } 2.5)
\end{gathered}
$$$$
30 \% \text { of } 2.5)
$$

Building sorueture costs

Equipmentcosts

Indireet

$1 \quad 29 \%$ of $2.5 .1 \leqslant 2.5 .2$ )

Subtotal of 2.5

$$
\begin{aligned}
& 2.5 .1 \\
& 2.5 .2 \\
& 2.5 .3
\end{aligned}
$$

2.6 Constuetion manapemeal cosis

2.7 Managemeal Reserve

2.8 Contingency

Sublotal 2.0

3.0

Trodection faciling construction conts

3.1 Desipo cost

3.2 Laspection cost

3.J Project manapemeat

3.4 Construction cost

3.4 .1
3.4 .2
3.4 .3

Subwotal of 3.4

35 Construction manapemer:!

3.6 Masngement Regrive

3.7 Contiopncy

Subcotal 3.0

4.0

Operations Bud get Punded Activities (Seo Soct 7)

4.1 Conecprual desige

4.2 Safety assurance

4.3 NEPA perminug ( $\$ 6$ Mill for Els. 51 Mill for EA)

4.4 Preparation for operations

4.5 Project Masagemedi

Subwolal 4.0

Total Initial Cost $(1.0,2.03 .0 * 4.0)$

5.0

Oparating and main timinesco costl

S.1 Annual opera un g costs

5.2 Annual utility costs

S.3 Anoual material costs

S.t Annual maintainence costs

5.s Contingency

Subroal 5.0
Towal 20 veas $O \&$ cosi 120 turnes Subroal 5.0 )

6.0

Decontamination \& Decormissioning
$17.1 \%$ of 2.5$)$

( $10 \%$ of 2.5)

( $25 \%$ of 2.1 throuph 2.7 )

Building strueture coss

Equipment costs

Indirea

$10 \%$ of 3.4 ) $\left\{\begin{aligned} 25 \% & \text { of } 3.4) \\ 7 \% & \text { of } 3.4\}\end{aligned}\right.$

( $\quad 29 \%$ of 3.4.1 3.4.2)

$(17.1 \%$ of 3.4$)$

( $10 \%$ of 3.4 )

( $25 \%$ of 3.1 through 3.5 )

$(1.5 \%$ of 3.0$)$

$(1 \%$ of 3.0$)$

( $100 \%$ of 5.0$)$

( $10 \%$ of 4.1 through 4.4)

Cost

$(\$ \times 1000)$

Medinm Large

$\begin{array}{rrr}\$ 1.650 & \$ 1.650 & \$ 1.650 \\ \$ 50 & \$ 50 & \$ 50 \\ \$ 150 & \$ 150 & \$ 150 \\ \$ 185 & \$ 185 & \$ 185 \\ \$ 509 & \$ 509 & \$ 509 \\ \$ 25 \$ 4 & \$ 2544 & \$ 2.544\end{array}$

$\$ 2+400-53.400$

$\$ 360 \quad \$ 3360 \quad \$ 360$

S84 584 58

$\$ 120 \quad \$ 120 \quad \$ 130$

$\$ 180 \quad \$ 180 \quad \$ 180$

$\$ 750 \quad \$ 750 \quad \$ 750$

$\$ 270 \quad \$ 270 \quad \$ 370$

$\$ 1.200 \quad \$ 1.200 \quad \$ 1.200$

$\$ 205 \$ 205 \quad \$ 205$

$\$ 120 \quad \$ 120 \quad \$ 120$

$\$ 1.122 \quad \$ 1.122 \quad \$ 1.1=2$

$\$ 5.611 \quad \$ 5.611 \quad \$ 5.611$

$\$ 9.923 \quad \$ 12.769 \quad \$ 16.643$

$\begin{array}{lll}\$ 2.779 & \$ 3.575 & \$ 4.660 \\ \$ 3,969 & \$ 5,107 & \$ 6.057\end{array}$

$\begin{array}{lll}\$ 14.901 & \$ 19.818 & \$ 26.047\end{array}$

$\begin{array}{lll}\$ 15.869 & \$ 19.774 & \$ 25.558\end{array}$

$\$ 8.923 \quad \$ 11.482 \quad \$ 14.965$

$\$ 39.693 \quad \$ 51.074 \quad \$ 66.570$

$\$ 6.788 \quad \$ 8.734 \quad \$ 11.383$

$\begin{array}{lll}\$ 3.969 & \$ 5.107 & \$ 6.657\end{array}$

$\begin{array}{lll}\$ 15.788 & \$ 20.315 & \$ 26.478\end{array}$

$\$ 82.909 \quad \$ 106,081 \quad \$ 139.048$

$\begin{array}{lll}\$ 1.244 & \$ 1.600 \quad \$ 2.086\end{array}$

$\begin{array}{lll}\$ 829 & \$ 1.067 & \$ 1.390\end{array}$

$\$ \$ .000 \quad \$ 6.000 \quad \$ 6.000$

$\$ 12.196 \quad \$ 19.084 \quad \$ 26.661$

$\$ 2.027 \quad \$ 2.775 \quad \$ 3.614$

$\$ 22.296 \quad \$ 30.526 \quad \$ 39.751$

$\begin{array}{lll}\$ 113,360 & \$ 15,362 & \$ 186,954\end{array}$

$\$ 6.020 \quad \$ 8.960 \quad \$ 11.760$

$\begin{array}{rrr}\$ 6.020 & \$ 8.960 & \$ 11.760 \\ \$ 324 & \$ 1.889 & \$ 3.742\end{array}$

$\$ 176 \quad \$ 363 \quad \$ 560$

$\$ 3.237 \quad \$ 4.055 \quad \$ 5.261$

$\$ 2.439 \quad \$ 3.817 \quad \$ 5.332$

$\begin{array}{rrr}\$ 12.196 & \$ 19.084 & \$ 26.606 ! \\ \$ 243.920 & \$ 381.080 & \$ 533.220\end{array}$

$\begin{array}{lll}\$ 7.404 & \$ 9.947 & \$ 12.045\end{array}$

$\$ 364,684$

8732819 


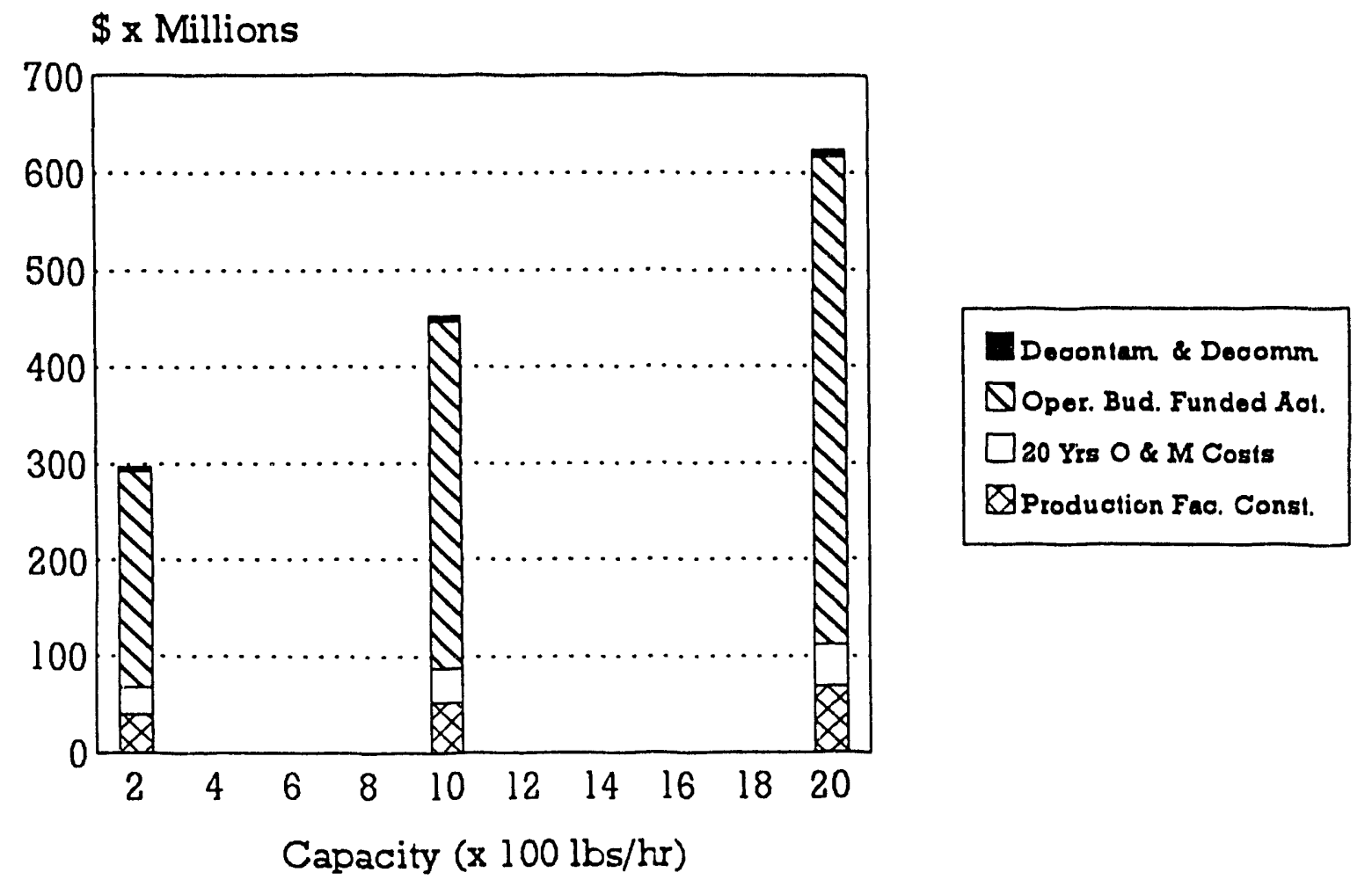

Figure 5-3. Cost versus capacity histogram for LLW/LLMW incineration facility (cost module DL).

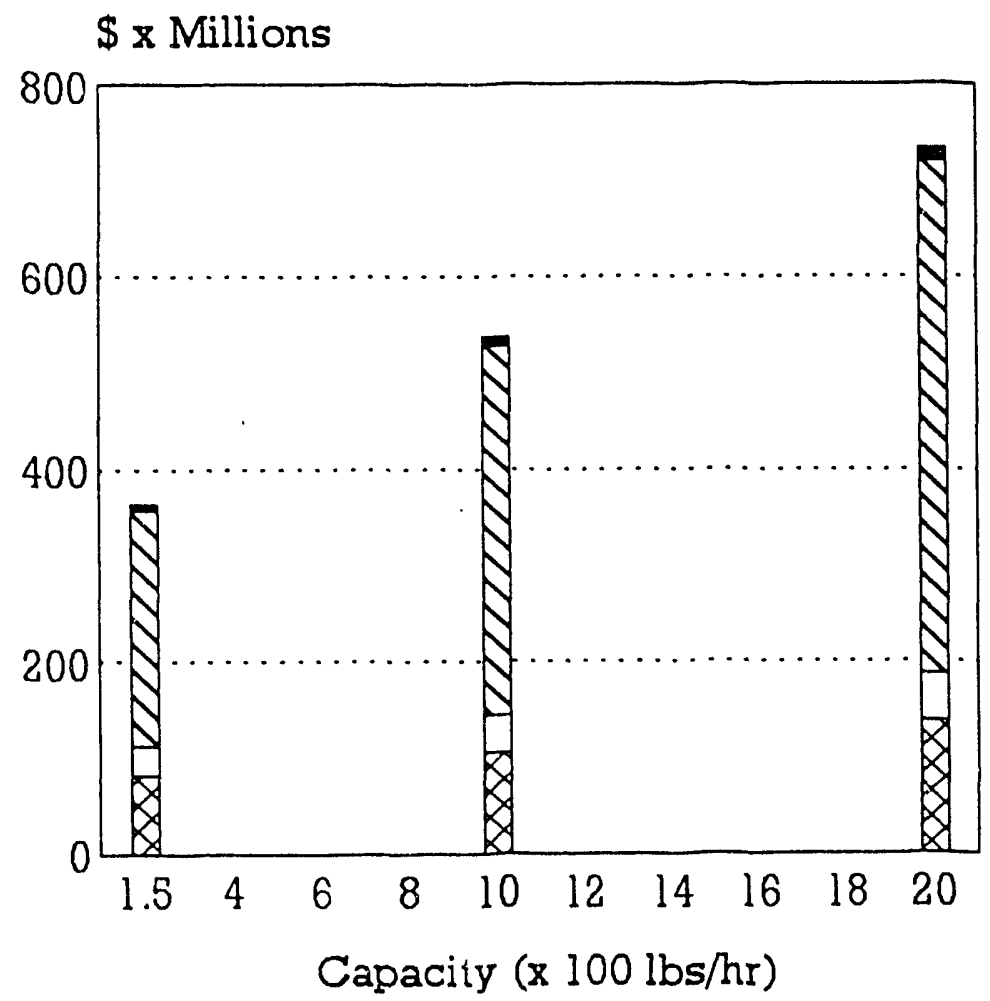

Decontam \& Decomm $\nabla_{20}$ Yrs 0 \& M Costs $\square$ Oper. Bud. Funded Act. $\triangle$ Production. Fac. Const.

Figure 5-4. Cost versus capacity histogram for alpha-LLW/LLMW incineration facility (cost module DA). 


\section{METAL MELTING FACILITY (COST MODULES EL AND EA)}

\subsection{Basic Information}

The metal melting facility, shown in Figure 6-1, is used either as an addition to the existing facility where similar functions are already available, or in conjunction with the treatment front-end and back-end support facilities (see cost modules $\mathrm{A}, \mathrm{B}, \mathrm{CA} / \mathrm{CL}, \mathrm{I}$, and JA/JL). Cost module EA is applicable to alpha-LLW/LLMW while cost module EL is for LLW/LLMW. Unit operations are given in Figure 6-2.

The facility involves ten process unit operations that convert metals into cast ingots and treat secondary liquid and gaseous wastes. Secondary waste treatment by-products, such as off-gas scrubber sludge and slag, are solidified and placed in drums. (Other general support functions are described in Appendix A.)

The facility is equipped for processing ferrous and nonferrous bulk metals of various shapes and forms such as waste containers, failed equipment, and contaminated scrap structural steel. The cost module is designed to handle incoming waste in 55-gal drums containing up to $10 \%$ combustibles. However, this facility cannot sort different metal types. The metals must, therefore, arrive at the facility presorted.

\subsection{Technical Bases and Assumptions}

\subsubsection{Functional and Operational Description}

Incoming sorted bulk metal is shredded and prepared via an input preparation and feed unit. The feed conveyor transports the shredded metal to an electric furnace, where the metal is melted and any accompanying combustible materials are thermally destroyed. A metal cooling and casting unit operation allows for withdrawal of the molten metal and slag from the furnace so it can be poured into ingots for casting and cooling.

The unit operations produce three secondary waste streams: slag, liquid, and off-gas. The slag is separated at the casting and cooling unit and placed into containers for disposal. Secondary liquid waste is processed in the liquid waste treatment unit that removes dissolved and suspended solids (organic and inorganic) from the liquid waste. The facility recycles and reuses the treated wastewater so that there is zero discharge 10 the environment. The melter off-gas system is equipped with a secondary combustion unit that completes the volatile gas destruction process. An induced air blower moves the secondary combustor effluent through air pollution control devices that are designed to rumove particulates, $\mathrm{SO}_{2}, \mathrm{HCl}$, and $\mathrm{NO}_{\mathrm{x}}$. A surge tank is provided for off-gas retention for reprocessing of melter exhaust in the event of : process upset.

In the solidification unit operation, liquid waste treatment sludge is mixed with a binder (such as Portland cement) in a drum. A predetermined mixing ratio is used to produce a stabilized waste form. The filled drums are washed with high-pressure water spray jets at the drum capping and washing unit operation. 


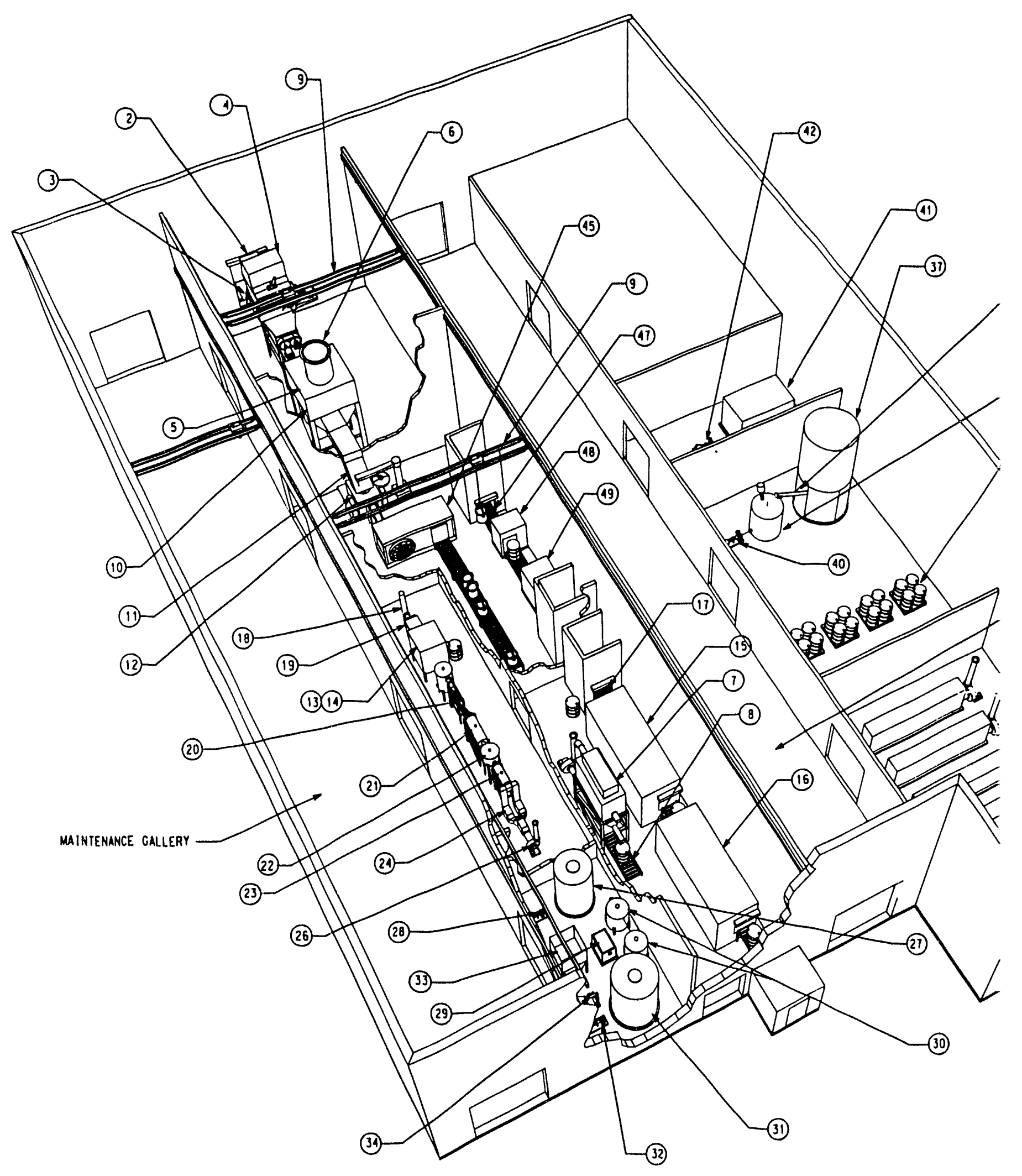

METAL MELTING FAT TOP PERSPECTIVE $\checkmark$

Figure 6-1. Typical arrangement for alpha-LLW/LLMW metal melting facility. 


\section{MAJOR EQUIPMENT LIST}

-(30)

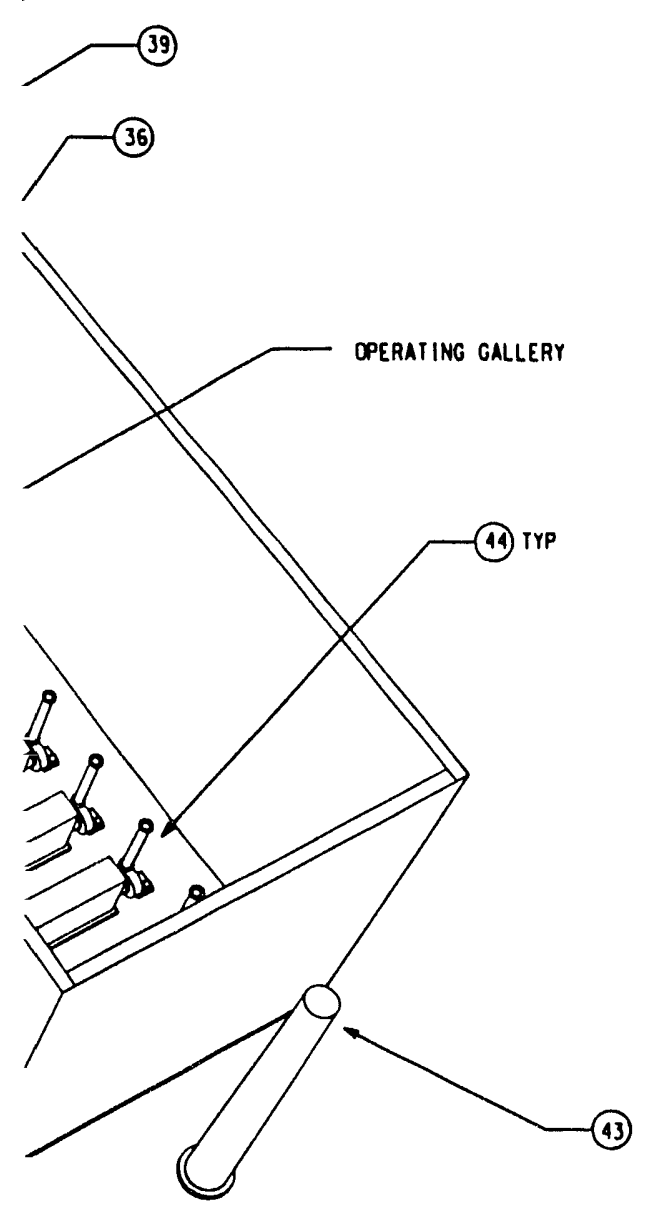

(1) BIN PUSHER

(2) INCOMING MASTE BIN

(3) BIN HOIST

(4) SHREDDER (2) WITH FEED HOPPER, OUST HOOO ANO

(5) SCREM CONVEYOR

(6) SHREDDED MASTE BIN

(7) DUSt Calector. 1.0. fan ano hepa filter

(B) DRUM STAGING CONVEYOR IPOMERED ROLLI

(9) Unoerhung crane Wi thin enclosed process area

(10) LIVE BOTTOM BULK STORAGE hopper

(11) REMOVABLE FEED CHUTE

(12) INOUCTION FURMACE (TILTING)

(13) CERAMIC Bag FILTER

(14) ORUM STAGING CONVEYOR (POMERED ROLL)

(15) SOLIDIFICATION SYSTEM

(16) DRUM CAPPING ANO MaSHING SYSTEM

(17) DRUM TRANSPORT CONYEYOR (POMERED ROLL)

(1B) AF TERBURNER

(19) GAS COOLER

(20) DOUBLE VENTURI

(21) CONOENSER

(22) MIST ELIMIMATOR

(23) REHEATER

(24) DOUBLE HEPA FILTERS

(25) FINAL HEPA FILTER

(26) 1.D. FAN

(21) RECEIVING TANK

(28) PUIP

(29) FILTER

(30) ION EXCHANGE

(31) TREATED MASTE TANK

(32) PUIP

(33) SLUOCE TANK

(34) PUIP

(35) Underhung Crane vithin ENCLosed mainienance area

(36) BINOER DRUMS

(37) LILE SILO

(38) SCREN CONVEYOR

(39) MIXING IANK

(40) FEED PUIMP

(41) CHILLER

(42) CIRC. PUNP

(43) STACK

(44) hepa filter ano fan

(45) REMOTE CONTROLLEO INGOT FORMING

(46) INGOT FORM STAGING CONVEYOR IPONEREO ROLL)

(47) OVERPACK STAGING CONVEYOR (POIERED ROLLI

(48) CAPPING DEVICE

(49) MASHING DEVICE

(50) TRANSFER MOHORAIL MITH HOIST 


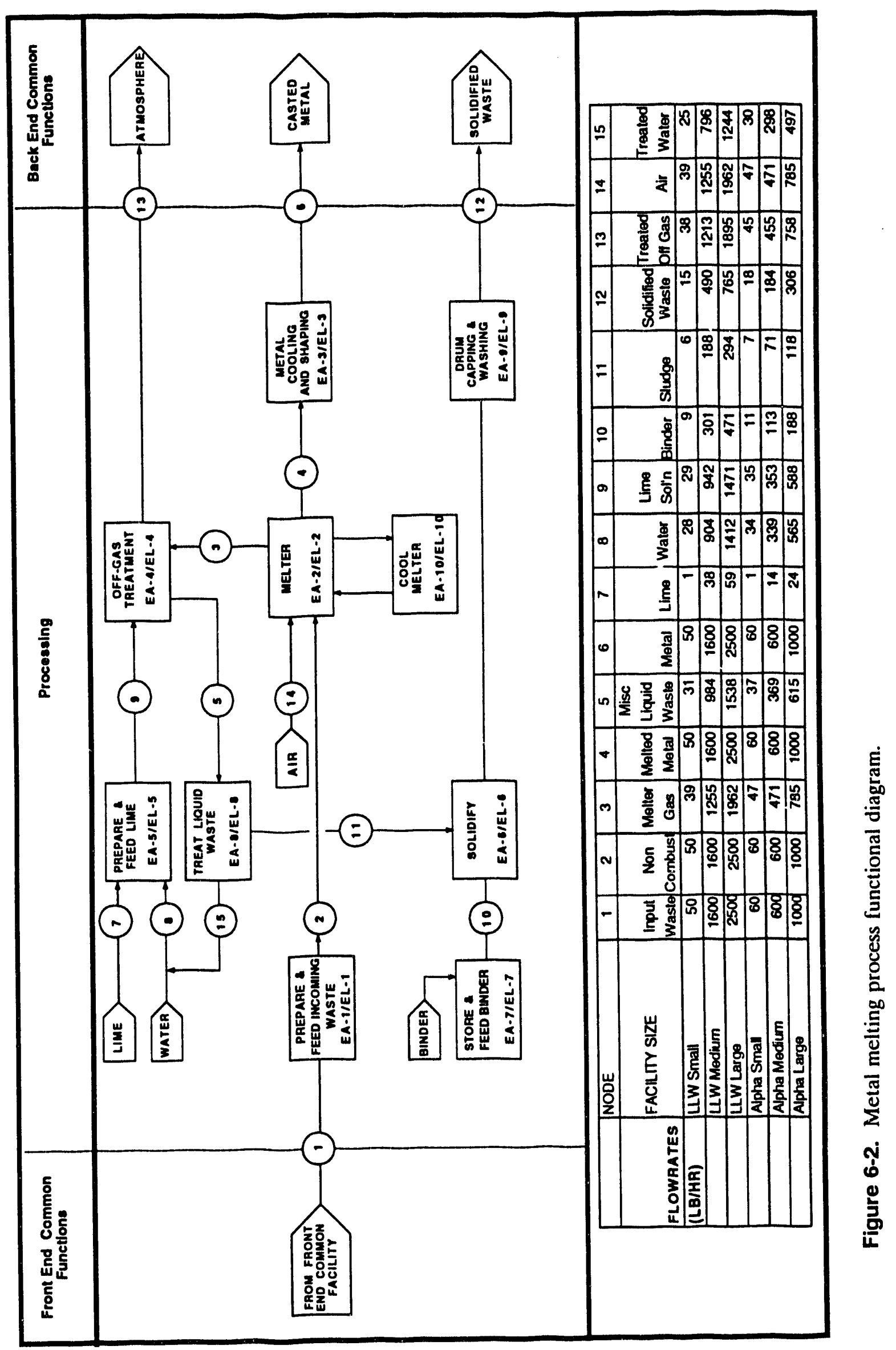


Drums containing solidified waste, slag containers, and cast metal ingots are the main output from this iacility. This output is ready for examinations by radioassay and final certification included in the back-end support facility.

The metal ingots can have a limited potential for reuse or may be disf ssed of safely in shallow land disposal units. The anticipated density of the solidified waste is $112 \mathrm{lbs} / \mathrm{ft}^{3}$, and the densities for cast metal are the same as their absolute densities.

\section{G.2.2 Facility Integration}

Major input is contaminated scrap metal either from the open, dump, and sort facility (cost module $\mathrm{CL}$ or $\mathrm{CA}$ ) or directly from generator sites through the unloading inspection facility (cost module B). Major O\&M purchased materials such as personnel protective equipment, laboratory material, binder, and disposable containers are assumed to be consumable supplies, and their respective costs are estimated accordingly.

Major discharges from the syste: are metal ingots, lag containers, and drums of solidified LLW/LLMW or alpha-LLW/LLMW waste that are transported to a back-end facility (see cost module I). Treated off-gas is discharged into the atmosphere.

\subsection{Cost Bases, Assumptions, and Assessmente}

General cost bases and assumptions are given in Appendix A. Facility specific items are discussed below.

- The metal sizing and preparation units (shredders), melter and off-gas treatment/scrubber system, and solidification tir is are major equipment capital cost items.

- Major equipment capital costs were verified against the purchased costs incurred by a cor.nmercial LLW waste processing facility (SEG facility in Oak Ridge) that recently began to operate a metal melting process.

- Estimated operating staff is shown in Table 6-1.

- Budgetary cost for the preparation and ieed unit is based on vendor quotes for shredders, conveyors, and dust collection equipment.

- Melter prices are based on budgetary quotes from Ajax Corporation. Overall facility costs are checked against a metal melting reference facility in Germany (Siempelkamp, Siempelkamp Street 45, 4150 Krefeld, Germany). ${ }^{5}$

- Callidus Technologies provided budgetary quotes for the various off-gas scrubbers.

- The selerted solidification unit is manufactured by Stock Equipment Company of Chagrin Falls, Cinio. This supplier provided a quote for a unit similar to that sold to DOE for a facility at the Savannah River Site.

- Small, medium, and large facility capacities and unit costs are shown in Table 6-2. 
Table 6-1. Estimated operating staff for metal melting facility (cost module EL and EA).

\begin{tabular}{|c|c|c|c|c|c|c|c|}
\hline $\begin{array}{c}\text { Unit } \\
\text { operation }\end{array}$ & Description & $\begin{array}{l}\text { Small } \\
\text { LLW }\end{array}$ & $\begin{array}{l}\text { Medium } \\
\text { LLW }\end{array}$ & $\begin{array}{l}\text { Large } \\
\text { LLW }\end{array}$ & $\begin{array}{l}\text { Small } \\
\text { alpha } \\
\text { (FTE) }\end{array}$ & $\begin{array}{c}\text { Medium } \\
\text { alpha } \\
\text { (FTE) }\end{array}$ & $\begin{array}{l}\text { Large } \\
\text { alpha } \\
\text { (FTE) }\end{array}$ \\
\hline E-1 & Prepare and feed incoming waste & 0 & 9 & 9 & 0 & 9 & 12 \\
\hline E-2 & Melter & 9 & 12 & 12 & 9 & 12 & 15 \\
\hline E-3 & Metal cooling and storing & 3 & 6 & 6 & 3 & 6 & 6 \\
\hline E-4 & Off-gas traatment & 1 & 3 & 3 & 1 & 3 & 6 \\
\hline E-5 & Prepare and feed lime & 1 & 3 & 3 & 1 & 3 & 6 \\
\hline E-6 & Solidify & 1 & 3 & 3 & 1 & 3 & 6 \\
\hline $\mathrm{E}-7$ & Store and feed binder & 1 & 3 & 3 & 1 & 3 & 3 \\
\hline E-8 & Treat liquid waste & 1 & 3 & 3 & 1 & 3 & 3 \\
\hline E-9 & Drum capping and washing & 0 & 0 & 0 & 1 & 1 & 1 \\
\hline E-10 & Cool melter & 0 & 0 & 0 & 0 & 0 & 0 \\
\hline E-11 & Electric dist and MCC & 0 & 0 & 1 & 1 & 0 & 0 \\
\hline E-12 & Heating, ventilation and exhaust & 0 & 0 & 0 & 1 & 1 & 1 \\
\hline \multirow[t]{2}{*}{ E-13 } & Other equipment & $\underline{4}$ & 4 & 7 & 4 & 7 & $\underline{13}$ \\
\hline & Total & 21 & 46 & 49 & 23 & 51 & 72 \\
\hline
\end{tabular}

Table 6-2. Capacities and cost information for metal melting facility (cost module EL and EA). ${ }^{a}$

\begin{tabular}{|c|c|c|c|c|c|c|c|c|}
\hline Mod. & Module & Facility & Life Cycle Cos & Capacity & Unit Cost & Capacity & Cap(Tot Vol) & Unit Cost \\
\hline & Description & & $(\$ \times 1000)$ & $(1 \mathrm{bs} / \mathrm{hr})$ & $(\$ / 1 b)$ & $(f+3 / h r)$ & $(f+3 \times 1000)$ & $(\$ / f t 3)$ \\
\hline $\mathrm{EL}$ & Metal Meltina & Small & $\$ 140.950$ & 50 & $\$ 34.96$ & 1 & 115 & $\$ 1.223 .52$ \\
\hline $\mathrm{EL}$ & Metal Melting & Medium & $\$ 293,306$ & 1,600 & $\$ 2.27$ & 46 & 3,686 & $\$ \$ 79.56$ \\
\hline $\mathrm{EL}$ & Metal Melting & Large & $\$ 335,527$ & 2,500 & $\$ 1.66$ & 71 & 5,760 & $\$ 58.25$ \\
\hline$E A$ & Metal Melting & Small & $\$ 194,798$ & 60 & $\$ 40.26$ & 2 & 138 & $\$ 1,409.13$ \\
\hline EA & Metal Melting & Medium & $\$ 372,028$ & 600 & $\$ 7.69$ & 17 & 1,382 & $\$ 269.12$ \\
\hline EA & Metal Melting & Large & $\$ 469.314$ & 1.000 & $\$ 5.82$ & 29 & 2.304 & $\$ 203.70$ \\
\hline
\end{tabular}

a. Average density used is $35 \mathrm{lbs} / \mathrm{ft}^{3}$ 


\subsection{Cost Summaries}

Cost summaries for the LLW/LLMW and alpha-LLW/LLMW metal melting cost modules are shown in Tables 6-3 and 6-4. Histograms for cost versus capacity are given in Figures 6-3 and 6-4. 
Table 6-3. PLCC estimate summary for alpha LLW/LLMW metal-melting facility (cost module EL). Cost component

Cost Items

\begin{tabular}{cc} 
Cost \\
\hline Small & $\begin{array}{c}(\$ \times 1000) \\
\text { Medium Large }\end{array}$ \\
\hline
\end{tabular}

1.0

Strodies and bench realo leat conts

1.1 Manpower costs during research

1.2 Equipment costs

is Installation costs

1.4 Project mana gement before tille I

1.5 Contingency

Subional 1.0
$10 \%$ of 1.1 through 1.3)

$25 \%$ of 1.1 through 1.4)

Demonstratios costs

2.1 Manpower costs during demonstration

2.2 Design cost

2.3 Inspection cost

2.4 Project management

2.5 Construction cosi

$$
\begin{aligned}
& 2.5 .1 \\
& 25.2 \\
& 2.5 .3
\end{aligned}
$$

Subrotal of 2.5

2.6 Coustruetion manngement costs

2.7 Masagemeni Reserve

2.8 Contingeney

Subwoul 2.0

3.0

Froduction facility cossurvetion conts

3.1 Desipo cosi

3.2 Inspection cost

3.3 Project managemeat

3.4 Construction cost

$$
3.4 .1
$$

Subroul of 3.4

3.5 Construel: vo ranangemeat

3.6 Mana pement Rexrve

3.7 Contingency

Subional 3.0

Oparatical Bod got Peroded Activitios (Seo Sect T)

4.1 Conceprual desige

4.2 Salery assurance

4.3 NEPA perwirting (\$ 6 Mill for ES. $\$ 1$ Mill for EA)

4.4 Preparation for operations

4.5 Project Masageoment

Subtotal 4.0

Tow Laitial Cost $(1.0 .2 .0 .3 .0 * 4.0)$

5.0

Operating and mintainenco costs

5.1 Analual operasing costs

S.2 Annual utility costs

5.3 Annual material cosis

5.t Annual mainlainonoc costs

s.5 Contingency

Subwoil 5.0

Tolal 20 year $O$ \& $M$ cosi ( 20 imes Sublotal 4.0 )

6.0

Decontamination \& Decommissioning
Building structure costs

Equipment costs

Indirect

$(\quad 29 \%$ of 25.1 (2.5.2)

$(17.1 \%$ of 25$)$

( $10 \%$ of 2.5 )

( $25 \%$ of 2.1 through 2.7)

$18 \%$ of 3.4$)$

$(7 \%$ of 3.4$)$

( $10 \%$ of 3.4$)$

Building strueture costs

Equipmen c costs

Indireet

$(29 \%$ of $3.4 .1 * 3.4 .2)$

( $17.1 \%$ of 3.4$)$

( $10 \%$ of 3.4 )

( $25 \%$ of 3.1 ithrough 3.5 )

( $1.5 \%$ of 3.0$)$

( $1 \%$ o( 3.0$)$

( $100 \%$ of 5.0$)$

( $10 \%$ of 4.1 (through 4.4)

$\begin{array}{rrr}s 1.050 & s 1.050 & s 1.050 \\ \$ s 0 & \$ 50 & s 50 \\ s 150 & \$ 150 & s 150 \\ \$ 125 & \$ 125 & s 125 \\ s 3 s 4 & \$ 344 & \$ 334 \\ \$ 1.719 & \$ 1.719 & s 1.719\end{array}$

$\begin{array}{lll}\text { so } & \text { so } & \text { so } \\ \text { so } & \text { so } & \text { so } \\ \text { so } & \text { so } & \text { so } \\ \text { so } & \text { so } & \text { so } \\ \text { so } & \text { so } & \text { so } \\ \text { so } & \text { so } & \text { so } \\ \text { so } & \text { so } & \text { so } \\ \text { so } & \text { so } & \text { so } \\ \text { so } & \text { so } & \text { so } \\ \text { so } & \text { so } & \text { so } \\ \text { so } & \text { so } & \text { so } \\ \text { so } & \text { so } & \text { so }\end{array}$

$\begin{array}{rrr}\$ 1.814 & \$ 3.473 & \$ 5.377 \\ \$ 705 & \$ 1.350 & \$ 1.702 \\ \$ 1.008 & \$ 1.929 & \$ 2.432\end{array}$

$\begin{array}{lll}\$ 1.890 & \$ 2.871 & \$ 3.763\end{array}$

$\$ 5.922 \quad \$ 12.084 \quad \$ 15.086$

$\$ 2.265 \quad \$ 4.337 \quad \$ 5.466$

$\$ 10.077 \quad \$ 19.292 \quad \$ 24.315$

$\$ 1.723 \quad \$ 3.299 \quad 54.158$

$\$ 1.008 \quad \$ 1.929 \quad \$ 2.432$

$\$ 53.832 \quad \$ 7.336 \quad \$ 9.246$

$\begin{array}{lll}\$ 20.167 & \$ 38.608 & \$ 48.662\end{array}$

$\begin{array}{lll}5303 & 5579 & 5730\end{array}$

$\$ 202 \quad \$ 386$

$\$ 6.000 \quad \$ 6.000$

$\$ 1.169 \quad \$ 1.841 \quad \$ 2.012$

$\$ 12.856 \quad \$ 20.250 \quad \$ 22.130$

$\$ 34,742$
360,577

$\$ 29.40 \quad \$ 6.440 \quad \$ 6.860$

$\begin{array}{lrr}\$ 15 & 56.450 & 50.600 \\ 55 & 5126 & 5197\end{array}$

$\$ 5 \$ 126 \quad \$ 197$

$\$ 1.186 \quad \$ 2.542 \quad \$ 3.18$

$\$ 1.036 \quad \$ 2.289 \quad \$ 2.580$

$\$ 5.182 \quad \$ 11.4+4 \quad \$ 12.901$

$\$ 103.640 \quad \$ 228.880 \quad \$ 258.020$

$\begin{array}{lll}\$ 2.568 & 53.849 & 54.996\end{array}$

$\$ 140,950 \quad 3293,506 \quad \$ 335,527$ 


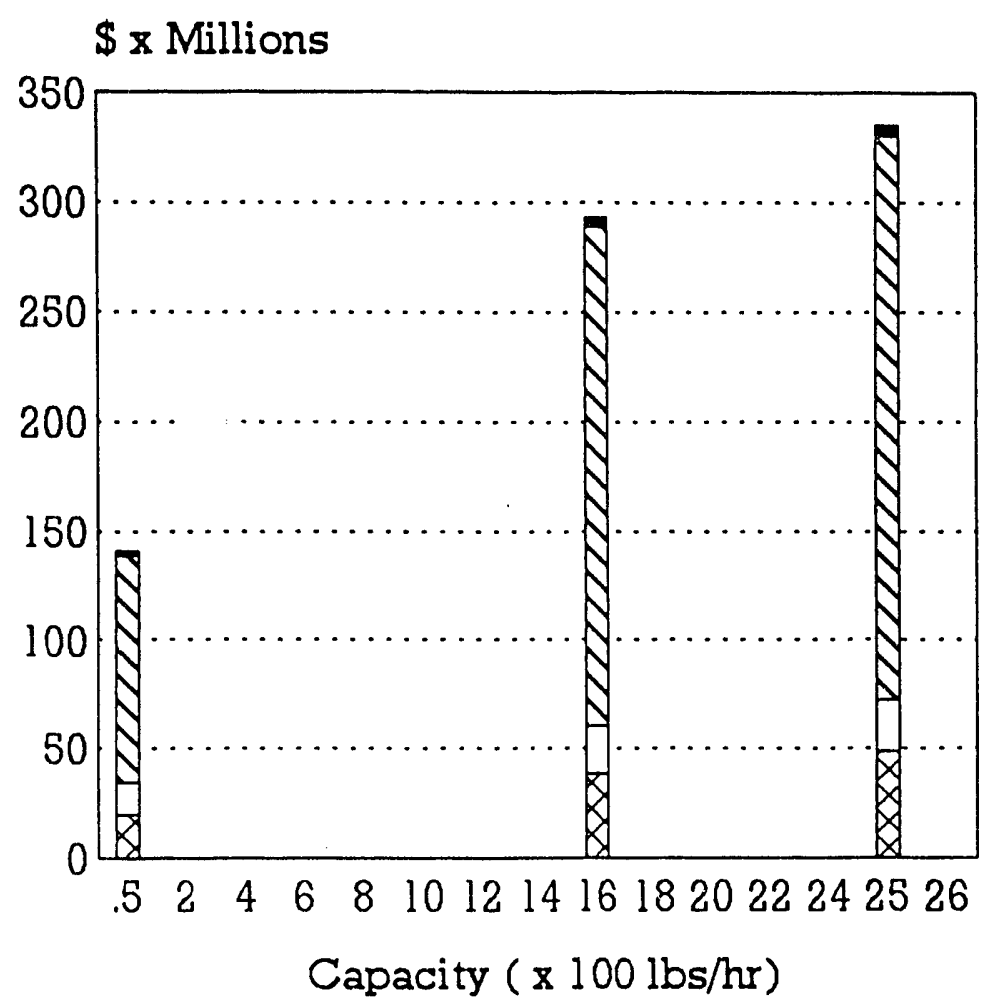

Decontam \& Decomm $\triangle 20$ Yrs O\&M Costs $\square$ Oper. Bud. Funded Aot. Broduotion Fao. Const.

Figure 6-3. Cost versus capacity histogram for LLW/LLMW metal melting facility (cost module EL). 
Table 6-4. PLCC estimate summary for LLW/LLMW metal-melting facility (cost module EA).

Cost

componeat
Cost Items

$10 \%$ of $(1.1$ through 1.3$)$

$(25 \%$ of 1.1 through 1.4$)$

Studias and beact scalo lest conts

1.1. Manpower cosus during resenrch

1.2 Equipment costs

1.3 Insullation costs

1.4 Project management before tide I

i.s Contingency

Subionl 1.0

$2.0 \quad 2$ Demonatration cost

2.1 Manpower costs during demonseration

2.2 Design cost

2.3 Inspection coss

2.4 Project toanapemeat

is Consuruetion cost

$$
2.5 .1
$$

Subtotal of 2.5

2.6 Construction management costs

2.7 Manapement Rexerv

2.8 Contingency

Sublotal 2.0

3.0

Frod ection facility conurrection conts

3.1 Design cost

3.2 Inspection cost

33 Project manapement

3.4 Consuruction cost

3.4 .1
3.4 .2
3.4 .3

Subromal of 3.4

3.5 Consuruction managemeat

3.6 Managemed Reserve

3.7 Contingency
Subroal 3.0

4.0

Operations Bodget Punded Activitias (Soo Sect T)

S.1 Conceprual desige

4.2 Safery assuradoce

13 NEPA permitring ( 6 Mill for EIS, S1 Mill for EA)

4.4 Preparation for operations

4.5 Project Managemeat

Sublomal 4.0

Toul Injitil Coet $(10,20,3.0 * 4.0)$

Building struenure costs

Equipment costs

Indireet

$(30 \%$ o( 2.5$)$

( 70 of 25$)$

$(\quad 29 \%$ of $2.5 .1 \& 2.5 .2)$

$(17.1 \%$ of 2.5$)$

( $10 \%$ o( 25$)$

( $25 \%$ ol 2.1 through 2.7)

Building struenuro costs
Equipmeat cossts
Indirect

$\left\{\begin{array}{r}25 \% \text { of } 3.4 \\ 7 \% \text { of } 3.4\end{array}\right.$

$10 \%$ of 3.4$)$

$(\quad 29 \%$ of $3.4 .1 * 3.4 .2)$

$17.1 \%$ o( 3.4)

$10 \%$ of 3.4$)$

$25 \%$ of 3.1 through 3.5$)$

$(15 \%$ of 3.0$)$

$(1 \% 0(3.0)$

( $100 \%$ of 5.0$)$

( $10 \%$ of 4.1 through 4.4)
Cost

\begin{tabular}{cc} 
Cost \\
\hline Small $\quad \begin{array}{l}(\$ \times 1000) \\
\text { Medium }\end{array}$ Large \\
\hline
\end{tabular}

Operating and main nimescos conts

5.1 Annual opera ung cosss

5.2 Annual utility costs

53 Annual material costs

5.4 Annual maingineso costs

5.S Contingeacy

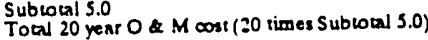

6.0 Deconlamination \& Decommiessioning

$\begin{array}{rrr}\$ 1.050 & \$ 1.050 & \$ 1.050 \\ \$ 50 & \$ 50 & \$ 50 \\ \$ 150 & \$ 150 & \$ 150 \\ \$ 125 & \$ 125 & \$ 125 \\ \$ 344 & \$ 344 & \$ 344 \\ \$ 1.719 & \$ 1.719 & \$ 1.719\end{array}$

siso

125

.719

ROM Lifo Gyde conts (20 years opern tion)

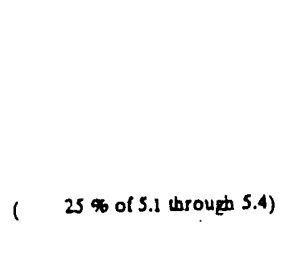




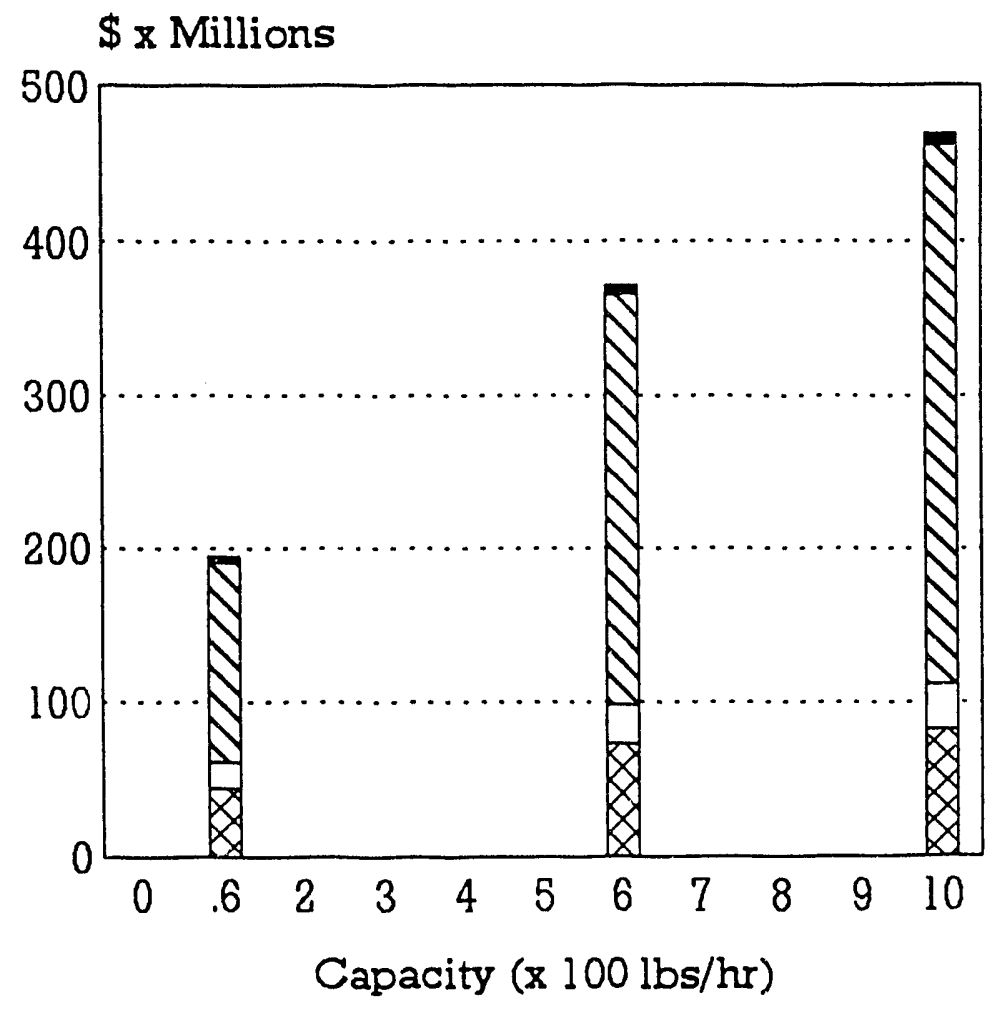

Decontam \& Decomm. $\nabla_{20}$ Yrs O\& M Costs $\square$ Oper. Bud. Funded Aat. 囚production Fac. Const

Figure 6-4. Cost versus capacity histogram for alpha-LLW/LLMW metal melting facility (cost module EA). 


\section{SHREDDING/COMPACTION FACILITY (COST MODULES FL AND FA)}

\subsection{Basic Information}

The shredding/compaction facility, shown in Figure 7-1, is used either as an addition to existing facilities where similar functions are already available or in conjunction with the treatment front-end and back-end support facilities (see cost modules $\mathrm{A}, \mathrm{B}, \mathrm{CA} / \mathrm{CL}, \mathrm{I}$, and JA/JL). Cost module FA is applicable to alpha-LLW, while cost module FL treats LLW. Unit operations are given in Figure 7-2.

This high force (1500-2000 metric ton) compaction facility is comprised of seven main process unit operations. The three main treatment steps are (a) size reduction of the incoming waste, (b) supercompaction of the reduced waste, and (c) solidification of secondary by-products (such as liquid waste and fugitive dust).

\subsection{Technical Basis and Assumptions}

\subsubsection{Functional and Operational Description}

The large facility is designed to shred the incoming waste and package it in 55-gal drums. This facility is equipped with a dust collection/filtration unit to treat air containing fugitive dust from the shredding operations. The small and medium sized facilities have such low capacities that the expense of a shredder cannot be economically justified and is not included. For these smaller facilities, the waste must be placed into drums before it arrives at the compaction unit operation.

At the compaction unit operation, a lift device places the filled drums onto press conveyors. The operator selects a drum from one of the conveyors and feeds it to the press through an airlock, located in the press negative pressure environmental chamber. A device pierces the drum to release any gases potentially trapped in the drum into the confined chamber. A high-pressure compactor (supercompactor) compresses the drum and transfers the pressed drum from the press to a staging conveyor (or turntable). A lift device picks up the compressed drum and places it into one of several overpacks located on an adjacent conveyor. After each overpack is filled, the operator feeds it to a sealing machine where a cap is placed on the overpack and sealed. The operator moves the sealed overpack to a drum washing unit where high-pressure water spray jets remove any loose contamination on the outside surface of the overpack.

Any liquid discharged during press operation is directed to a sump. A liquid waste treatment and a solidification unit operation is provided for treatment and solidification of any liquid effluent or other potentially radioactive waste generated at the facility.

The compacted waste is ready for processing through a radioassay and final certification, which are included in the back-end support facility.

The anticipated density of the compacted waste is about 60 to $70 \mathrm{lbs} / \mathrm{ft}^{3}$. The solidified waste density is $112 \mathrm{lbs} / \mathrm{ft}^{3}$. 


\subsubsection{Facility Integration}

Primary facility input are contaminated drummed waste from generator sites. The large facility is designed to accept bulk waste from both the open, dump, and sort facility (cost module CA or CL) and directly from the generator sites. Major O\&M purchased materials such as personnel protective equipment, laboratory material, binders, and overpacks are assumed to be consumable supplies and their costs are estimated accordingly.

Major facility outputs are compacted drums containing solidified LLW or alpha-LLW, which are transferred to a back-end support facility (see cost module 1). The overpacks (85-gal drums) containing compacted waste and 55 gal drums containing solidified waste are the main output from this facility. Treated off-gas is discharged into the atmosphere.

\subsection{Cost Bases, Assumptions, and Assessments}

General cost bases and assumptions are given in Appendix A. Facility specific items are discussed below.

- Waste size reduction and preparation (shredders), supercompactor, and solidification units are the major equipment capital cost items.

- Major equipment capital costs are verified against the purchased costs incurred by a U.S. Navy low-level waste processing facility (B\&W facility at Lynchburgh, West Virginia) that recently started operation.

- $\quad$ Estimated operating staff are shown below in Table 7-1.

- Budgetary cost for the preparation and feed unit is based on vendor quotes for shredders, conveyors, and dust collection equipment.

- Supercompactor prices are based on budgetary quotes by Stock Equipment Company, Chagrin Falls, Ohio.

- A fully automated solidification unit operation is selected for the large facility. This unit cost is quoted by Stock Equipment Company, the supplier of a similar unit for a DOE facility at the Savannah River Site.

- Small, medium, and large facility capacities and unit costs are as shown in Table 7-2.

\subsection{Cost Summaries}

Cost summaries for the LLW/LLMW and alpha-LLW/LLMW shredding/compacting cost modules are shown in Tables 7-3 and 7-4. Cost versus capacity is given in Figures 7-3 and 7-4.

As shown, the initial capital costs are about the same for the small and medium facility. This is due to size limitations of super-compaction equipment. The smallest such equipment can handle the small and medium capacities specified for the shredding/compaction facility.

The Alpha-LLW/LLMW large facility unit cost is higher than the medium size facility because the large facility includes shredding and has a proportionately smaller additional capacity (50\%) over the medium facility in comparison to the LLW/LLMW facility. 


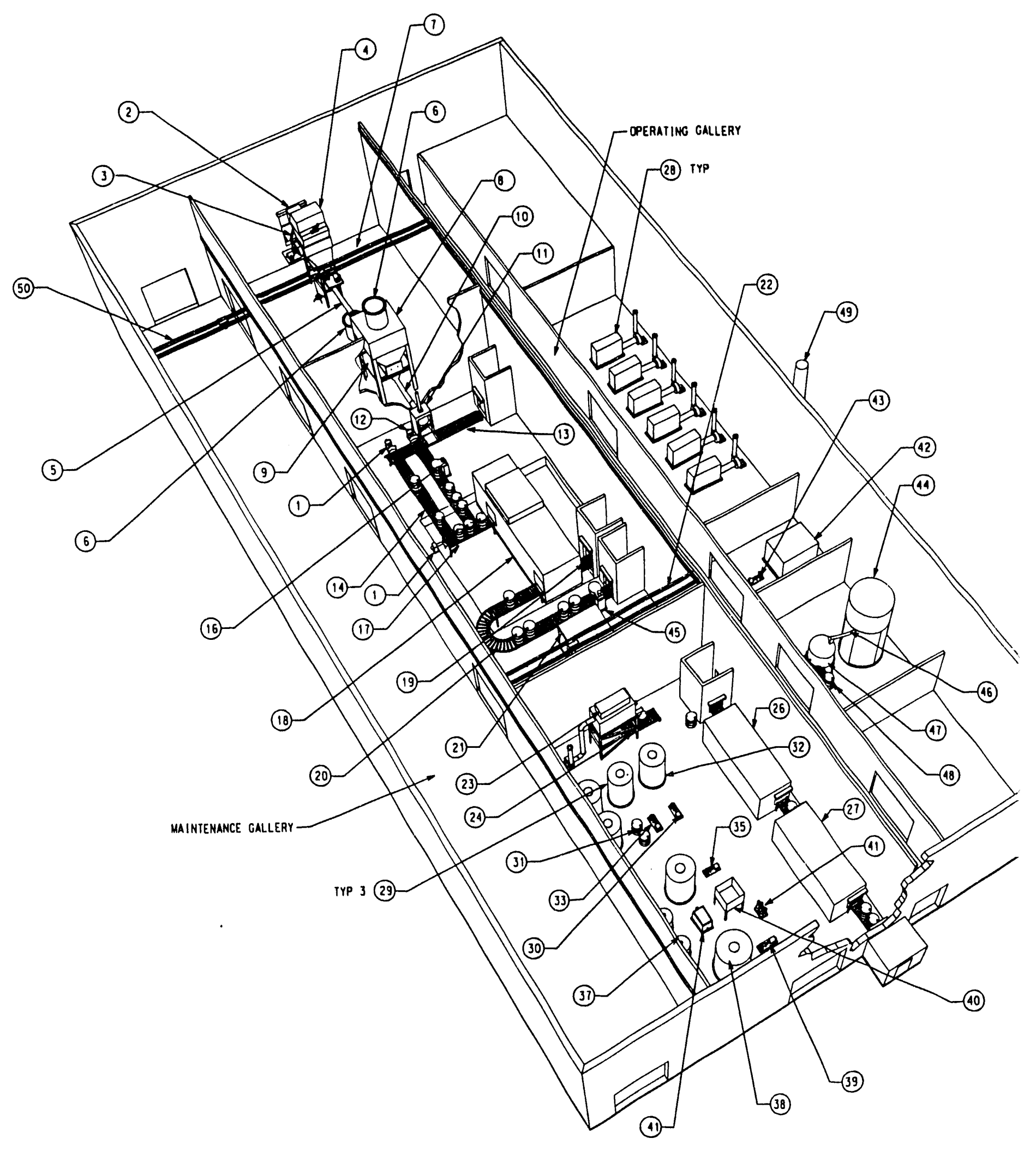
SHREDDING AND COMPACTI
TOP PERSPECTIVE 


\section{MAJOR EQUIPMENT LIST}

(1) DRUM PUSHER

(2) INCOMING MASTE BIN

(3) $S K I P$

(4) SHREDDER 121 WITH FEED HOPPER. OUST hOOO ANO HYORAULIC RAM

(5) AUCER FEEDER

(6) Maste transfer biN

(7) Inoerhung crane in enclosed process area

(8) LIVE BOTTOM BULK STORAGE HOPPER

(9) tert Iary Shredoer

(10) nuGer FeEder

(i1) SHAEDOEO MASTE COMPACTOR I30 TONI

(12) ORUM PUSHER

(19) ORUM STAGING CONVEYOR (POMERED ROLL)

(14) DRUM STAGING CONVEYOR (POMEREO ROLL)

(15) COMPACTED DRUM STAGING CONVEYOR (POMERED ROLL)

(16) DRUM top seaming station

(17) SUPERCOAPACTOR FEED CONVEYOR (POMERED ROLLI)

(18) MOOULAR SUPERCONPACTOR UNIT I2000 TONI

(19) EIPTY OVERPaCK Stacing CONVEYor (POMEREO ROLLI

(20) SUPERCOMPACTED CONTAINER STAGING CONVEYOR IPOMERED ROLLI

(21) ModULAR hYORAULIC POMER UNIT

(22) UNOERHUng CRane IN ENCLOSED process area

(23) OUST COLLECTOR. faN ANO hePA FILTER

(24) ORUM STAGING CONVEYOR (POWERED ROLLI

(25) ORUM STAGing CONVEYOR (POMERED ROLL)

(26) SOL IOIFICATION SYSTEM

(27) DRUM CAPPING ANO MASHING SYSTEM

(28) HEPA FILTER AND FAM

(29) NeUtral IZATION TANK

(30) neutialized leachate punp

(31) reagent stoRace metering pUMPS

(32) DRUM leachate collection tank

(33) Leachate puip

(34) RECEIVING TANK

(35) PUNP

(36) FILTER

(37) ION EXCHANGE

(38) treated MASTE tanK

(39) PUNP

(40) SLUDCE TANK

(41) PUNP

(42) CHILLER

(43) CIRC. PUIP

(44) STDRAGE BIN

(45) OVERPaCK TOP SEAMING STATION

(46) PNEUMATIC CONVEYoR

(47) OAY BIN

IN FACILITY

(48) DRUM STORAGE CONVEYOR (GRAVITY)

IIEW

(49) STACX

(50) UNDerHung CRANe in enclosed MAINTENANCE AREA 


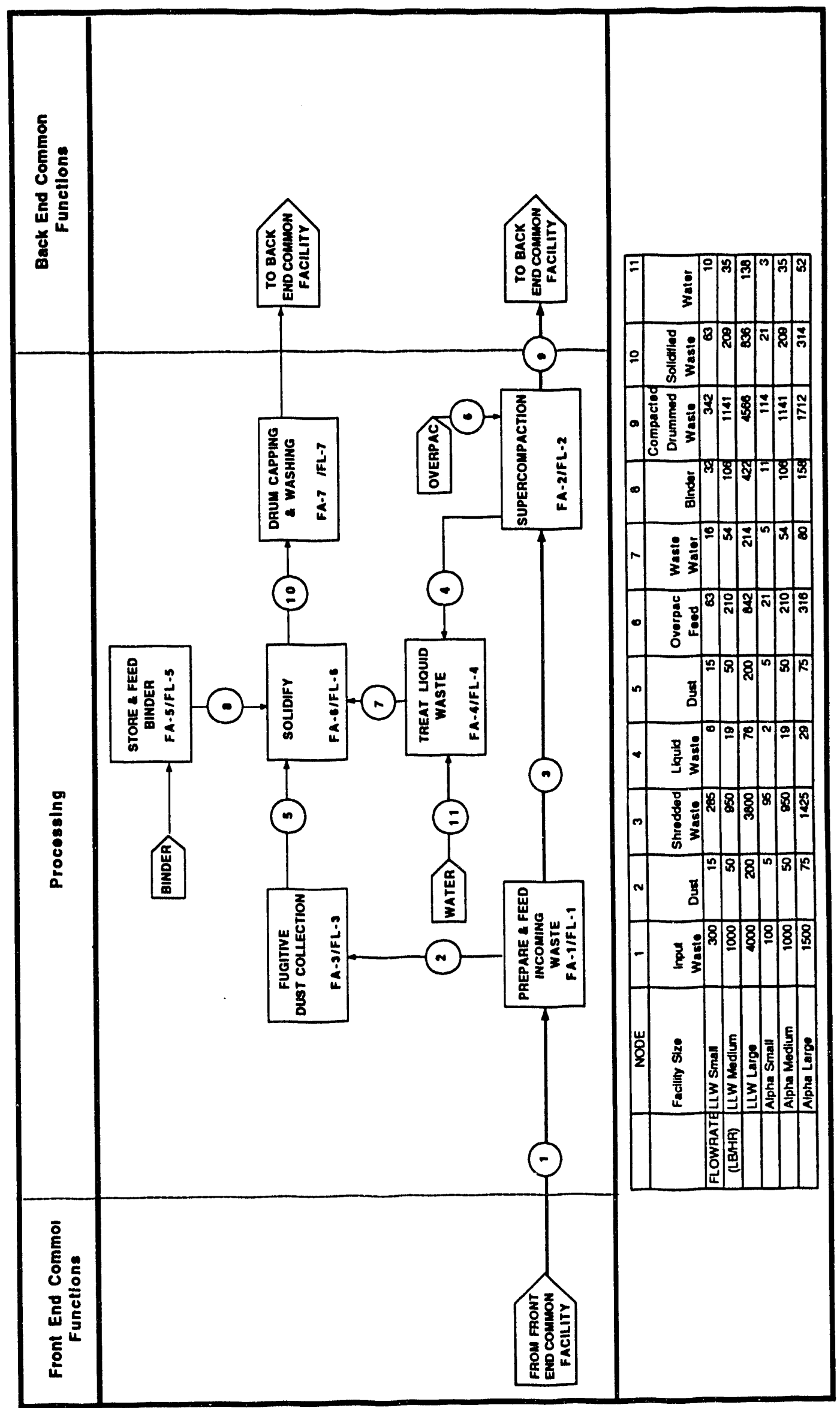

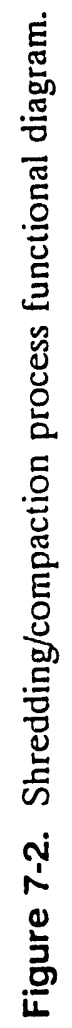


Table 7-1. Estimated operating staff for shredding and compaction facility (cost module F).

\begin{tabular}{llccc}
\hline $\begin{array}{l}\text { Unit } \\
\text { operation }\end{array}$ & \multicolumn{1}{c}{ Description } & $\begin{array}{c}\text { Small } \\
\text { (FTE) }\end{array}$ & $\begin{array}{c}\text { Medium } \\
\text { (FTE) }\end{array}$ & $\begin{array}{c}\text { Large } \\
\text { (FTE) }\end{array}$ \\
\hline F-1 & Prepare and feed incoming waste & 0 & 0 & 7 \\
F-2 & Supercompaction & 9 & 9 & 10 \\
F-3 & Fugitive dust collection & 0 & 0 & 1 \\
F-4 & Treat liquid waste & 1 & 1 & 2 \\
F-5 & Store and feed binder & 1 & 1 & 2 \\
F-6 & Solidify & 1 & 2 & 3 \\
F-7 & Drum capping and washing & 0 & 0 & 0 \\
F-8 & Electrical distribution and MCC & 0 & 1 & 1 \\
F-9 & Cool compactor & 0 & 0 & 0 \\
F-10 & Heating, ventilation, and exhaust & 0 & 3 & 3 \\
F-11 & Overpack storage & 0 & 0 & 0 \\
F-12 & Other equipment & $\underline{0}$ & $\underline{0}$ & $\underline{0}$ \\
& Total & 12 & 17 & 29 \\
\hline
\end{tabular}

Table 7-2. Capacities and cost information for shredding and compaction facility (module FL and FA). ${ }^{a}$

\begin{tabular}{|c|c|c|c|c|c|c|c|c|}
\hline Mod. & Module & Facility & Life Cycle Cost & apacity & Unit Cos & Capacity & Cap(Tot Vol) & Unit Cost \\
\hline & Description & & $(\$ \times 1000)$ & $(\mathrm{lbs} / \mathrm{hr})$ & $(\$ / 1 b)$ & $(f+3 / h r)$ & $(\mathrm{ft} 3 \times 1000)$ & $(\$ / f t 3)$ \\
\hline$|F|$ & Shred/Comnact & Small & a100750 & 200 & 01.10 & 9 & $601:$ & 014577 \\
\hline $\mathrm{FL}$ & Shred/Compact & Medium & $\$ 120,979$ & 1000 & $\begin{array}{l}\$ 4.110 \\
\$ 150\end{array}$ & 29 & 2.304 & $\$ 52.51$ \\
\hline FL' & Shred/Compact & Large & $\$ 235,121$ & 4.000 & $\$ 0.73$ & $\because 14$ & 9,216 & $\$ 25.51$ \\
\hline$F A$ & Shred/Compact & Smail & $\$ 111,222$ & 100 & $\$ 13.79$ & 3 & 230 & $\$ 482.73$ \\
\hline$F A$ & Snred/Compact & Medium & $\$ 126,232$ & 1.000 & $\$ 1.57$ & 29 & 2,304 & $\$ 54.79$ \\
\hline FA & Shred/Compact & Large & $\$ 255,361$ & 9,500 & $\$ 2.11$ & 43 & 3,456 & $\$ 73.89$ \\
\hline
\end{tabular}

a. Average density used is $35 \mathrm{lbs} / \mathrm{ft}^{3}$ 
Table 7-3. Rough order of magnitude (ROM) life-cycle cost estimate summary for shredding and compaction.

Cost

component

Cost Items

Cost

\begin{tabular}{c} 
Cost \\
\hline Small $\begin{array}{c}(\$ \times 1000) \\
\text { Medium }\end{array}$ Large
\end{tabular}

Srudian and beach acalo last conts

1.1 Manpower costs during research

1.2 Equipment conts

1.3 Installation costs

1.4 Project management before tivo I

13 Contingency

Subtotal 1.0

$10 \%$ of 1.1 throus 1.3)

$25 \%$ of 1.1 through 1.4)

Demanetration conte

2.1 Manpower cosus during demonstration

2.2 Desifp cost

2.3 Inspection cost

2.4 Project management

2.5 Construction cont

$$
25.1
$$

25.2

Subtonal of 25

$$
2.53
$$

2.6 Consuruction manazement cosls

2.7 Manapemeni reserve

2.8 Contin $\%$ ncy

Sublotal 2.0

3.0

Production fscility consultuction cost

3.1 Desifn cosi

3.2 Inspection cost

33 Project mannifemen

3.4 Construction cost

$$
3.4 .1
$$

Subtotal of 3.4

3.43

3.5 Consuruction manapemen

3.6 Management Rexerve

3.7 Contingency

Sublotal 3.0

4.0 Operations Budgat Puaded Activities (Sea Sect 7)

4.1 Conceprual desigen

4.2 Sa fery nesuranoce

4J NEPA permitting (\$ 6 Mill for EIS. $\$ 1$ Mill for EA)

4.4 Preparation for operations

4.5 Project Managemen!

Sublotal 4.0

Total Initiv $\operatorname{Cost}(1.0,2.0,3.0<4.0)$

Building structure costs

Equipment costs

Indiree

( $29 \%$ of $2.5 .1 * 2.5 .2$ )

$(17.1 \%$ of 2.5$)$

$10 \%$ of 2.5$)$

( $25 \%$ of 2.1 through 2.7)

$7 \%$ or 2.5$)$

( $10 \%$ of 2.5 )

Operatiog and maintuinencos costs

S.1 Annual opera tingeosis

5.2 Annual urility cos 4

5.3 Annual materis costs

5.4 Annual main uinence costs

Ss Contingency

Subioul 5.0

Tolal 20 year $O \&$ M cost ( 20 times Subtotal 5.0 )

Building strueture cosss

Equipmentcosts

Indiree

$(\quad 29 \%$ of $3.4 .1 \& 3.4 .2)$

$(17.1 \%$ of 3.4$)$

( $10 \%$ of 3.4 )

( $25 \%$ or 3.1 through 35 )

\begin{tabular}{|c|c|c|}
\hline$\$ 750$ & $\$ 750$ & 5750 \\
\hline$\$ 50$ & $\$ 50$ & $\$ s 0$ \\
\hline s1so & $\$ 150$ & $\$ 150$ \\
\hline 595 & 393 & 595 \\
\hline 5261 & $\$ 261$ & $\$ 261$ \\
\hline$\$ 1,306$ & $\$ 1,306$ & $\$ 1,306$ \\
\hline so & so & so \\
\hline 30 & so & 50 \\
\hline so & so & so \\
\hline so & so & so \\
\hline so & so & so \\
\hline so & so & so \\
\hline so & so & so \\
\hline so & $\$ 0$ & so \\
\hline so & so & so \\
\hline so & so & so \\
\hline so & so & so \\
\hline so & so & so \\
\hline$\$ 1,518$ & \$1.535 & $\$ 3.143$ \\
\hline$\$ 590$ & $\$ 597$ & $\$ 1.222$ \\
\hline 5843 & 5853 & $\$ 1.746$ \\
\hline 52,112 & $\$ 2.112$ & 53,568 \\
\hline 54,425 & $\$ 1,500$ & 59,966 \\
\hline$\$ 1,896$ & $\$ 1,917$ & 53.225 \\
\hline 58,433 & $\$ 8.529$ & $\$ 17,459$ \\
\hline$\$ 1,442$ & $\$ 1.458$ & $\$ 2,985$ \\
\hline 5843 & 5853 & $\$ 1,746$ \\
\hline$\$ 3,207$ & $\$ 3,243$ & $\$ 6,639$ \\
\hline$\$ 16,876$ & 517,003 & $\$ 34,940$ \\
\hline$\$ 253$ & 5256 & $\$ 524$ \\
\hline$\$ 169$ & $\$ 171$ & $\$ 349$ \\
\hline$\$ 6,000$ & $\$ 6,000$ & $\$ 8,000$ \\
\hline$\$ 3,446$ & 54,395 & $\$ 8,842$ \\
\hline$\$ 987$ & $\$ 1,082$ & $\$ 1572$ \\
\hline$\$ 10,855$ & $\$ 11.904$ & $\$ 17.287$ \\
\hline$\$ 29,037$ & 830,278 & 853,533 \\
\hline$\$ 1,820$ & $\$ 2,380$ & $\$ 4,060$ \\
\hline sil & $\$ 19$ & 549 \\
\hline$\$ 73$ & $\$ 244$ & 5979 \\
\hline 5852 & 5873 & $\$ 1,986$ \\
\hline 5689 & $\$ 879$ & $\$ 1,768$ \\
\hline$\$ 3,446$ & $\$ 4,395$ & $\$ 8,842$ \\
\hline 568,920 & 587,900 & $\$ 176,840$ \\
\hline 52,801 & $\$ 2.801$ & $\$ 4,748$ \\
\hline$\$ 100,758$ & $\$ 120,979$ & 3235,121 \\
\hline
\end{tabular}

$15 \%$ of 3.0$)$

( $100 \%$ of 5.0 )

( $10 \%$ of 4.1 through 4.4)

Deconnmination \& Decommissioning

( $25 \%$ of 5.1 through 5.4 )

6.0

ROY Lifo Ggde costs (20 yean opers tion) 
Table 7-4. ROM life-cycle cost estimate summary for alpha shredding and compaction.

Cost component

Cost Items

Cost

(\$口1000)

Small Medium

Large

1.0

Srudies and bench realo heal conts

1.1 Manpower costs during research

1.2 Equipment costs

13 Inswallation coss

1.4 Project managemeat before tille I

1.5 Contingercy

Subtotal 1.0

2.2 Design cost

2.3 Inspection cost

2.4 Project mannpement

2.5 Construction cost

2.7 Manngemeni Reserve

2.8 Contingency

3.1 Design cost

3.2 Inspection cos

3.7 Contingency

4.0

5.5 Coatingency

6.0 Deconamination \& Decommissioning

Demonum tion cost

2.1 Manpower cos s during demonsuration

$$
\begin{aligned}
& 2.5 .1 \\
& 2.5 .2 \\
& 2.5 .3
\end{aligned}
$$

Subtotal of 25

2.6 Construction management costs

Subroral 2.0

Traduction fality construction conts

3.3 Project manapemen

3.4 Construction cos!

3.4 .1
3.4 .2
3.4 .3

Subromal of 3.4

3.5 Construction management

3.6 Manayemeni Reserve

Subtotal 3.0
Operations Bodget Pund od Activities (See Sect. 7)

4.1 Conceptual design

4.2 Safery assuradoc

4.3 NEPA permitting ( 56 Mill for EIS. 51 Mill for EA)

4.4 Preparation for operations

4.5 Project Management

Subcoial 4.0

Total Initial Cost $(1.0,2.0,3.0 \approx 4.0)$

Building structure costs

Equipmeni costs

Indirect

( $10 \%$ of 1.1 through 13)

(25\% of 1.1 through 1.4)

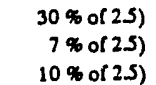

$10 \%$ of 2.5$)$

( $\quad 29 \%$ of 25.1 \& 2.5.2)

( $17.1 \%$ of 2.5 )

( $10 \%$ o( 2.5)

( $25 \%$ of 2.1 through 2.7)

Building structure costs

Equipment costs

Indirect

Operating and maintainemos corets

S1 Annual operating costs

5.2 Annual utility costs

5.3 Annual material costs

5.4 Annual mainuinence costs

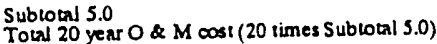

$\begin{array}{lll}\text { so } & \text { so } & \text { so } \\ \text { so } & \text { so } & \text { so } \\ \text { so } & \text { so } & \text { so } \\ \text { so } & \text { so } & \text { so } \\ \text { so } & \text { so } & \text { so } \\ \text { so } & \text { so } & \text { so }\end{array}$

$10 \% 0(3.4)$

( $29 \%$ of $3.4 .1 * 3.4 .2)$

$(17.1 \%$ of 3.4$)$

( $10 \%$ o(3.4)

( $25 \%$ of 3.1 through 3.5 )

( $15 \%$ of 3.0 )

$\left(\begin{array}{r}15 \% \text { of } 3.0) \\ (1 \% \text { or } 3.0)\end{array}\right.$

( $100 \%$ of 5.0$)$

( $10 \%$ of 4.1 through 4.4)

( $25 \%$ of 5.1 through 5.4)

ROM Lifo cycle costs (20 years operation)

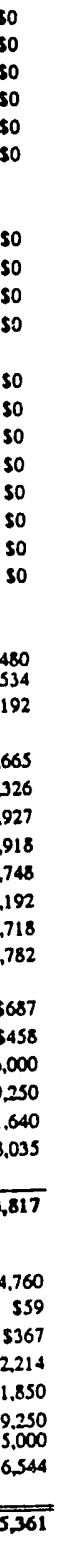




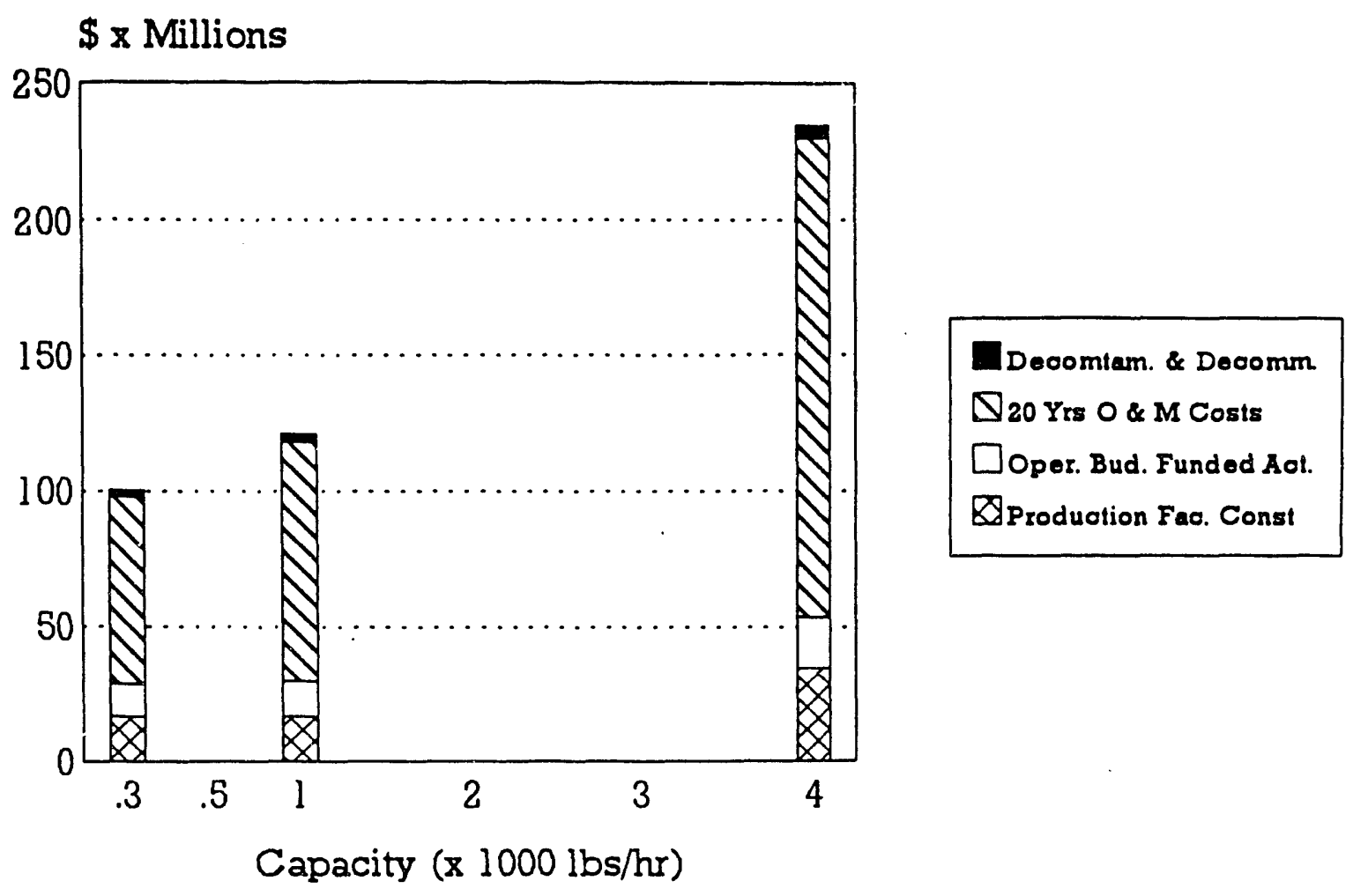

Figure 7-3. Cost versus capacity histogram for LLW/LLMW shredding and compaction facility (cost module FL).

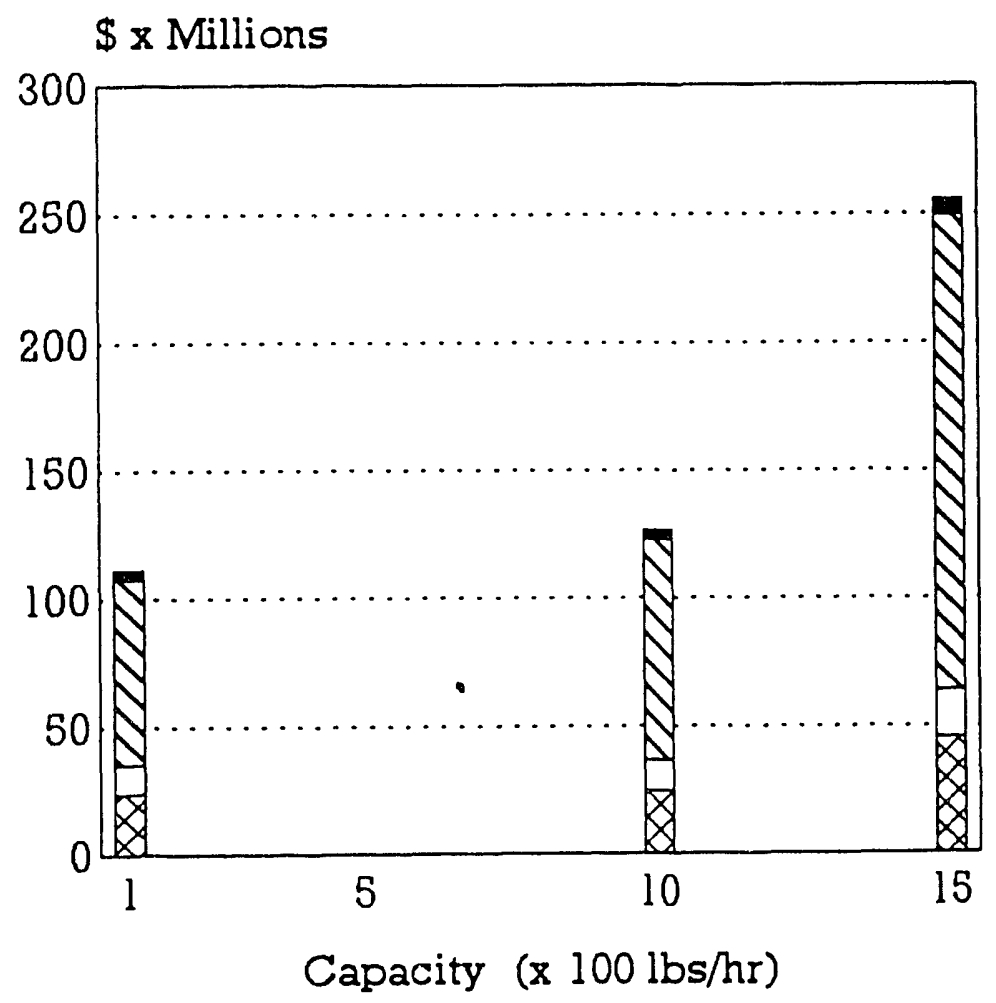

Decontam \& Decomm $\nabla_{20}$ Yrs 0 \& M Costs $\square$ Oper. Bud. Funded Aot. 囚produotion Fao. Const.

Figure 7-4. Cost versus capacity histogram for alpha-LLW/LLMW shreriding and compaction facility (cost module FA). 


\section{SOLIDIFICATION FACILITY (COST MODULES GL AND GA)}

\subsection{Basic Information}

The solidification facility, shown in Figure 8-1, is used either as an addition to an existing facility where similar functions are already available or in conjunction with the treatment front-end and backend support facilities (see cost modules $A, B, C A / C L, I$, and JA/JL). The primary purpose of this facility is the solidification of solid and liquid waste and sludge that arrives directly from storage facilities or the generators. Solidification process used in other facilities is only for treatment of secondary waste. Cost module GA is applicable to alpha-LLW/LLMW, and module GL is for LLW/LLMW. Unit operations are shown in Figure 8-2.

The facility is composed of five main process unit operations that incorporate all buildings, systems, processes, equipment, devices, controls, and accessories required to solidify the incoming solid and liquid waste. Main treatment steps are size reduction of the incoming solid waste, treatment of the incoming liquid waste and sludge, and solidification of these waste streams.

This facility processes both noncombustible solids and inorganic liquid waste. A certain amount of oily liquid waste can be tolerated, since a budget for an oil removal unit is included to provide for removal of suspended oil in the incoming liquid waste. The crusher/shredder in the solid waste preparation unit can accept solids up to approximately $1 \mathrm{ft}^{3}$.

\subsection{Technical Bases and Assumptions}

\subsubsection{Functional and Operational Description}

The facility receives liquid waste via a pipeline. A liquid waste treatment unit is used to concentrate the waste and feed it to a solidification unit operation. An incoming waste preparation and feed unit crushes and shreds incoming solid waste; the shredded waste is then collected in a storage hopper.

The solidification unit operation solidifies liquid waste, solid waste, or a combination of the two. The unit has a remotely operated in-drum solidification assembly equipped with intake tanks and hoppers for solid and liquid waste and binder. To accomplish the solidification process, a drum is placed onto a transfer cart. The cart moves the drum to various fill stations where feeders place solid and liquid waste and binder in the drum. Next, the cart moves the filled drum to a mixing station where the drum is capped and tumbled to achieve the required mixture. The cart moves the drum for a repeat of the filling/mixing step to maximize the fill efficiency.

After proper mixing, the operator remotely moves the filled container to a capping and washing unit. This unit operation provides for sample collection, capping of the container, and removal of loose contamination from the container surface by high-pressure spray water jets. The cont.inerized waste is ready for processing through radioassay and final certification, which are included in the back-end tacility (cost module I).

The anticipated density of the solidified waste is $112 \mathrm{bbs} / \mathrm{ft}^{3}$. 


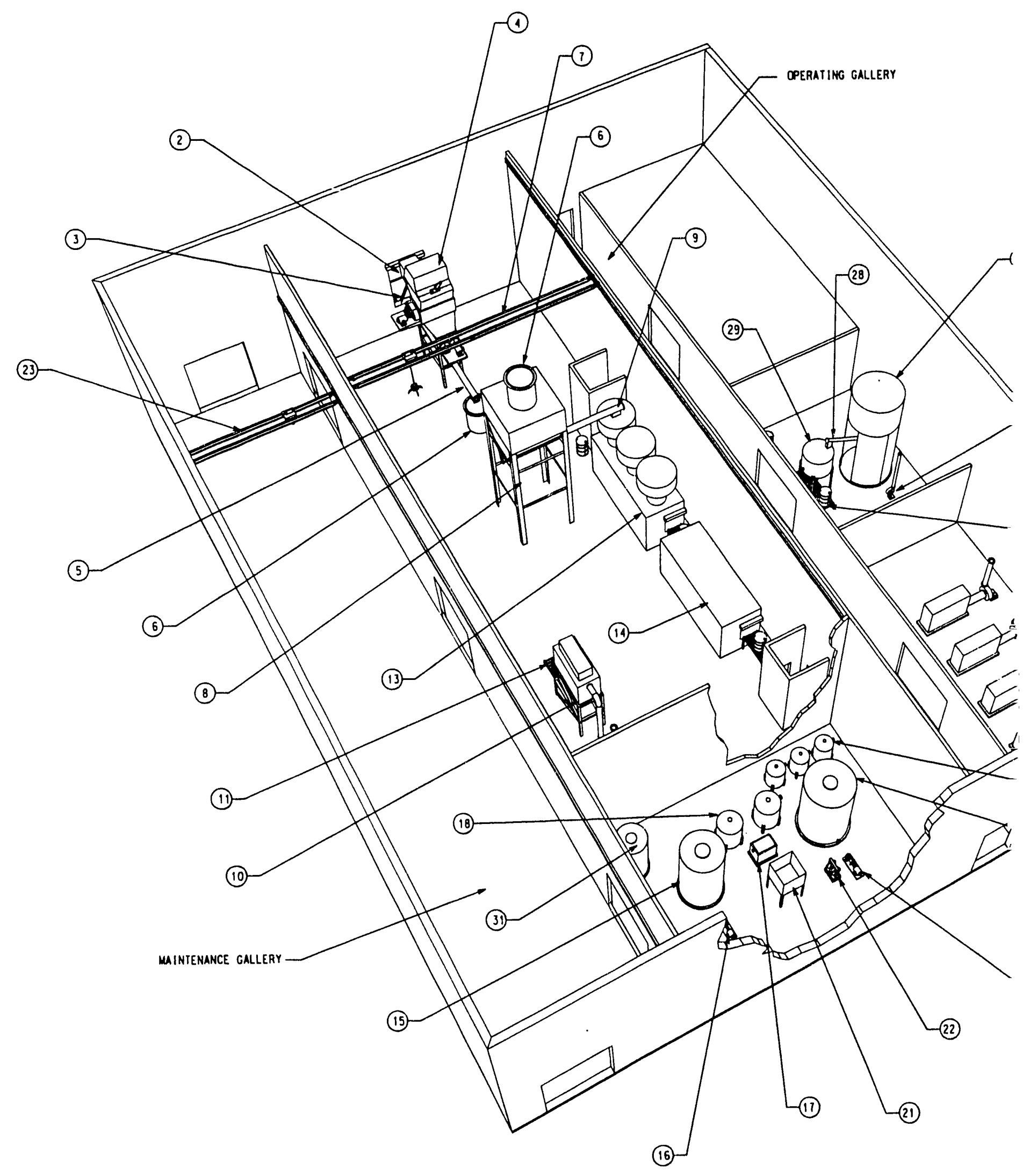

WASTE SOLIDIFICATION

TOP PERSPECTIVE

Figure 8-1. Typical arrangement for alpha-LLW/LLMW solidification facility. 


\section{MAJOR EQUIPMENT LIST}

6)

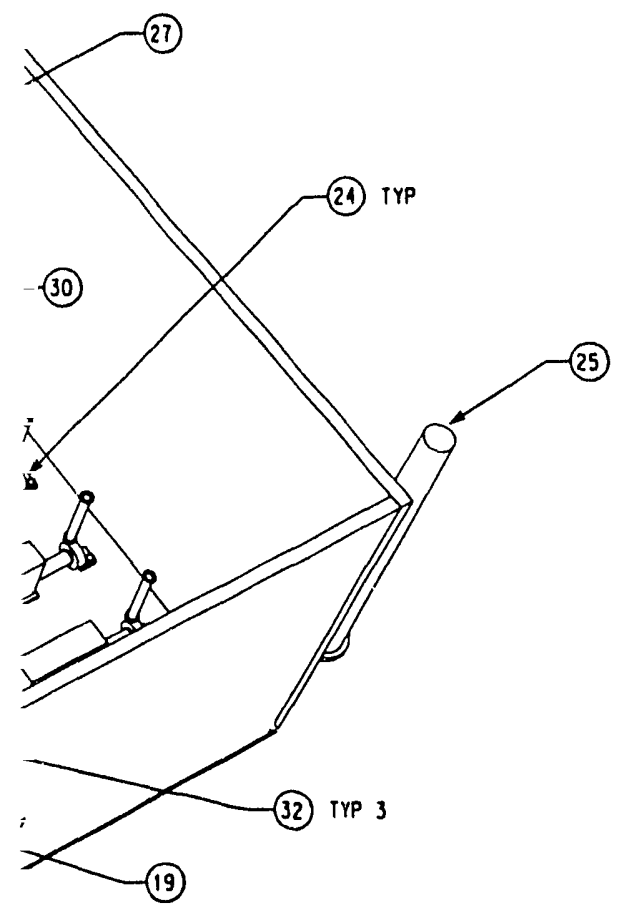

\section{FACILITY}

VIEW
(1) DRUM PUSHER

(2) INCOMING MASTE BIN

(3) BIN HOIST

(4) SHREDDER (2) WITH FEED HOPPER. DUST hOOD AND hYDRAUL IC RAM

(5) AUCER FEEDER

(6) MASTE tRanSFER BIN

(7) underhung crane in enclosed process area

(8) LiVE BOTTOM BULK STORAGE HOPPER

(9) AUGER FEEDER

(10) DUSt COllector. fan and hepa filter

(11) DRUM STAGING CONVEYOR (POWERED ROLL)

(12) DRUM STAGING CONVEYOR (POWERED ROLLL)

(13) SOLIOIFICATION SYSTEM

(14) DRUM CAPping AND maSHING SYStem

(15) RECEIVING TANK

(16) PUMP

(17) FILTER

(18) Ion EXChange vessels

(19) TREated maste tank

(20) PUMP

(21) SLUDGE TANK

(22) PUNP

(23) Underhung crane in enclosed maintenance area

(24) hePA FILTER ANO faN

(25) STACK

(26) Sinder stopace silo

(27) BLOWER

(28) PNEUMATIC CONYEYOR

(29) DAY BIN

(30) DRUM Staging CONVEYoR (GRAVITY)

(31) precipitation takik

(32) organic Removal FILter VeSSELS 


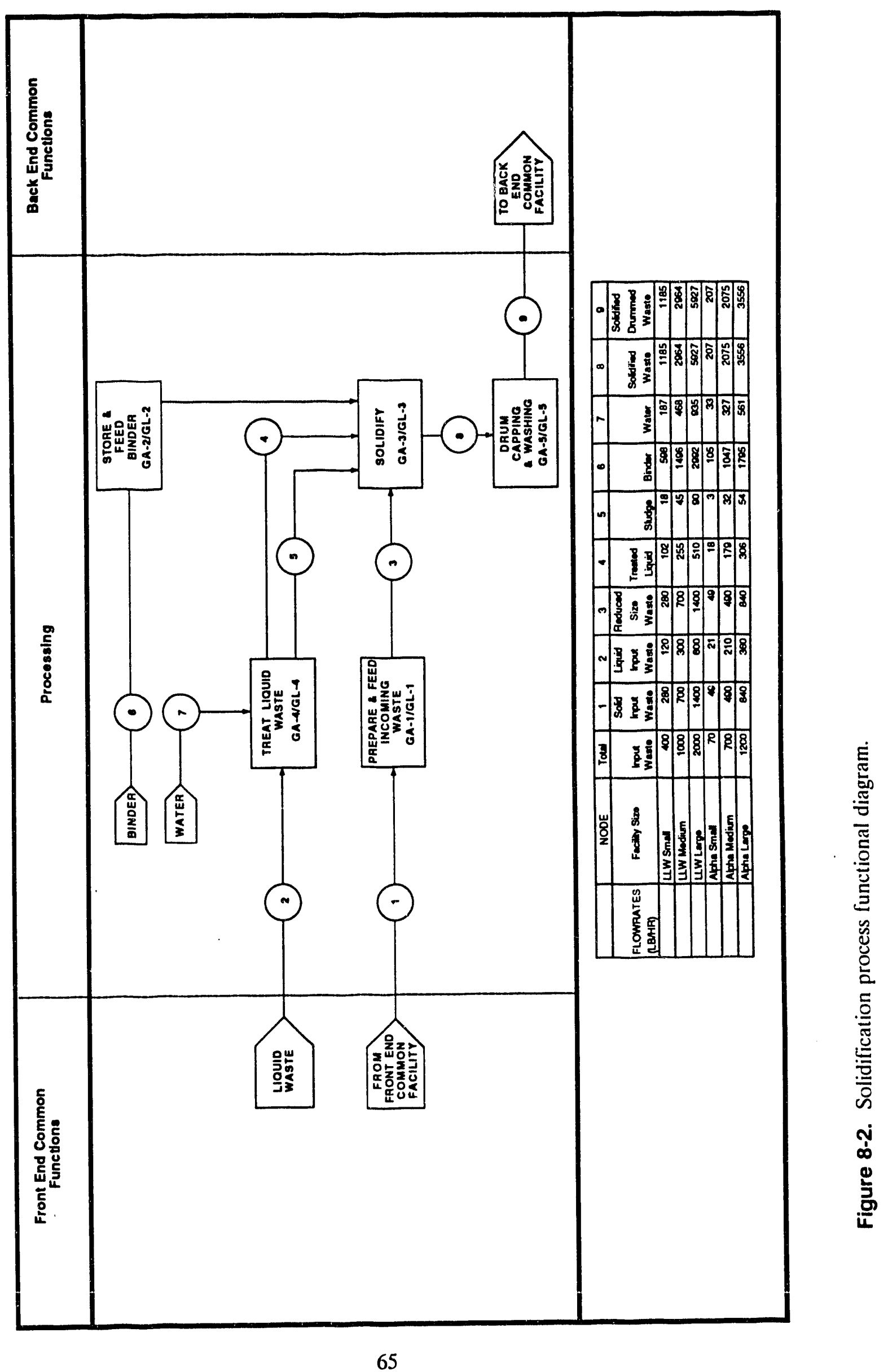




\subsubsection{Facility Integration}

Major facility input is comprised of inorganic liquid waste from the generator sites and bulk solid waste from the open, dump, and sort facility (cost module CA or CL) and from the generator sites. Major O\&M purchased materials such as personnel protective equipment, laboratory material, binder, and containers are assumed to be consumable supplies and their costs are estimated accordingly.

Major facility output is drummed solidified LLW/LLMW or alpha-LLW/LLMW, which is transferred to a back-end facility (see cost module I). Treated off-gas is discharged into the atmosphere.

\subsection{Cost Bases, Assumptions, and Assessments}

General cost bases and assumptions are given in Appendix A. Facility specific items are discussed below.

- Incoming waste size reduction and preparation (shredders) and solidification mixers are the major equipment capital cost items.

- Budgetary costs for the preparation and feed unit are based on vendor quotes for shredders, conveyors, and dust collection equipment.

- $\quad$ Estimated operating staff is shown in Table 8-1.

- Solidification facility assembly prices are based on quotes by Stock Equipment Company.

- The input waste is assumed to be $30 \%$ liquids and $70 \%$ solids.

- Small, medium, and large facility capacities and unit costs are shown in Table 8-2.

\subsection{Cost Summaries}

Cost summaries for the alpha-LLW/LLMW and LLW/LLMW solidification cost modules are shown in Tables 8-3 and 8-4. Histograms for cost versus capacity are shown in Figures 8-3 and 8-4. 
Table 8-1. Estimated operating staff for solidification facility (cost modules GL and GA).

\begin{tabular}{|c|c|c|c|c|c|c|c|}
\hline $\begin{array}{c}\text { Unit } \\
\text { operation }\end{array}$ & Description & $\begin{array}{l}\text { Small } \\
\text { alpha } \\
\text { (FTE) }\end{array}$ & $\begin{array}{l}\text { Small } \\
\text { LLW }\end{array}$ & $\begin{array}{c}\text { Medium } \\
\text { alpha } \\
\text { (FTE) }\end{array}$ & $\begin{array}{c}\text { Medium } \\
\text { LLW }\end{array}$ & $\begin{array}{l}\text { Large } \\
\text { alpha } \\
\text { (FTE) }\end{array}$ & $\begin{array}{l}\text { Large } \\
\text { LLW }\end{array}$ \\
\hline G-1 & Prepare and feed incoming waste & 4 & 4 & 10 & 10 & 13 & 13 \\
\hline G-2 & Store and feed binder & 2 & 2 & 4 & 4 & 7 & 7 \\
\hline G-3 & Solidify & 7 & 7 & 13 & 13 & 20 & 48 \\
\hline G-4 & Treat liquid waste & 2 & 2 & 4 & 4 & 7 & 4 \\
\hline G-5 & Drum capping and washing & 4 & 4 & 7 & 7 & 10 & 7 \\
\hline G-6 & Electrical distribution and $\mathrm{MCC}$ & 2 & 2 & 4 & 4 & 4 & 4 \\
\hline G-7 & Heating, ventilation, and exhaust & 4 & 4 & 4 & 4 & 1 & 4 \\
\hline \multirow[t]{2}{*}{ G-8 } & Other equipment & $\underline{4}$ & $\underline{4}$ & 7 & 4 & $\underline{13}$ & 7 \\
\hline & Total & 29 & 29 & 53 & 50 & 75 & 94 \\
\hline
\end{tabular}

Table 8-2. Capacities and cost information for solidification facility (cost module GL and GA). ${ }^{\mathrm{a}}$

\begin{tabular}{|c|c|c|c|c|c|c|c|c|}
\hline Mod. & Module & Facility & Life Cycle Cos & Capacity & Unit Cost & Capacity & Cap(Tot Vol) & Unit Cost \\
\hline & Description & & $(\$ \times 1000)$ & (Ibs/hr) & $(\$ / 1 b)$ & $(\mathrm{ft} 3 / \mathrm{hr})$ & $(\mathrm{ft} 3 \times 1000)$ & $(\$ / f t 3)$ \\
\hline & & & & & & & & \\
\hline Lي & dification & Small & $\$ 162,181$ & 400 & $\$ 5.03$ & 11 & 922 & $\$ 175.9$ \\
\hline GL & Icatio & Medium & $\$ 260,896$ & 1,000 & $\$ 3.24$ & 29 & 2,304 & $\$ 113.24$ \\
\hline$G L$ & icatio & Large & $\$ 451,794$ & 2,000 & $\$ 2.80$ & 57 & 4,608 & $\$ 98.05$ \\
\hline GA & ication & Smail & $\$ 200,672$ & 70 & $\$ 35.55$ & 2 & 161 & $\$ 1,244.25$ \\
\hline$G A$ & Solidification & Medium & $\$ 311,764$ & 700 & $\$ 5.52$ & 20 & 1,613 & $\$ 193.31$ \\
\hline & or & La & $\$ 431,332$ & 1,200 & $\$ 4.46$ & 34 & 2,765 & $\$ 156.01$ \\
\hline
\end{tabular}

a. Average density used is $35 \mathrm{lbs} / \mathrm{ft} .^{3}$ 
Table 8-3. PLCC estimate summary for LLW/LLMW solidification facility (cost module GL).

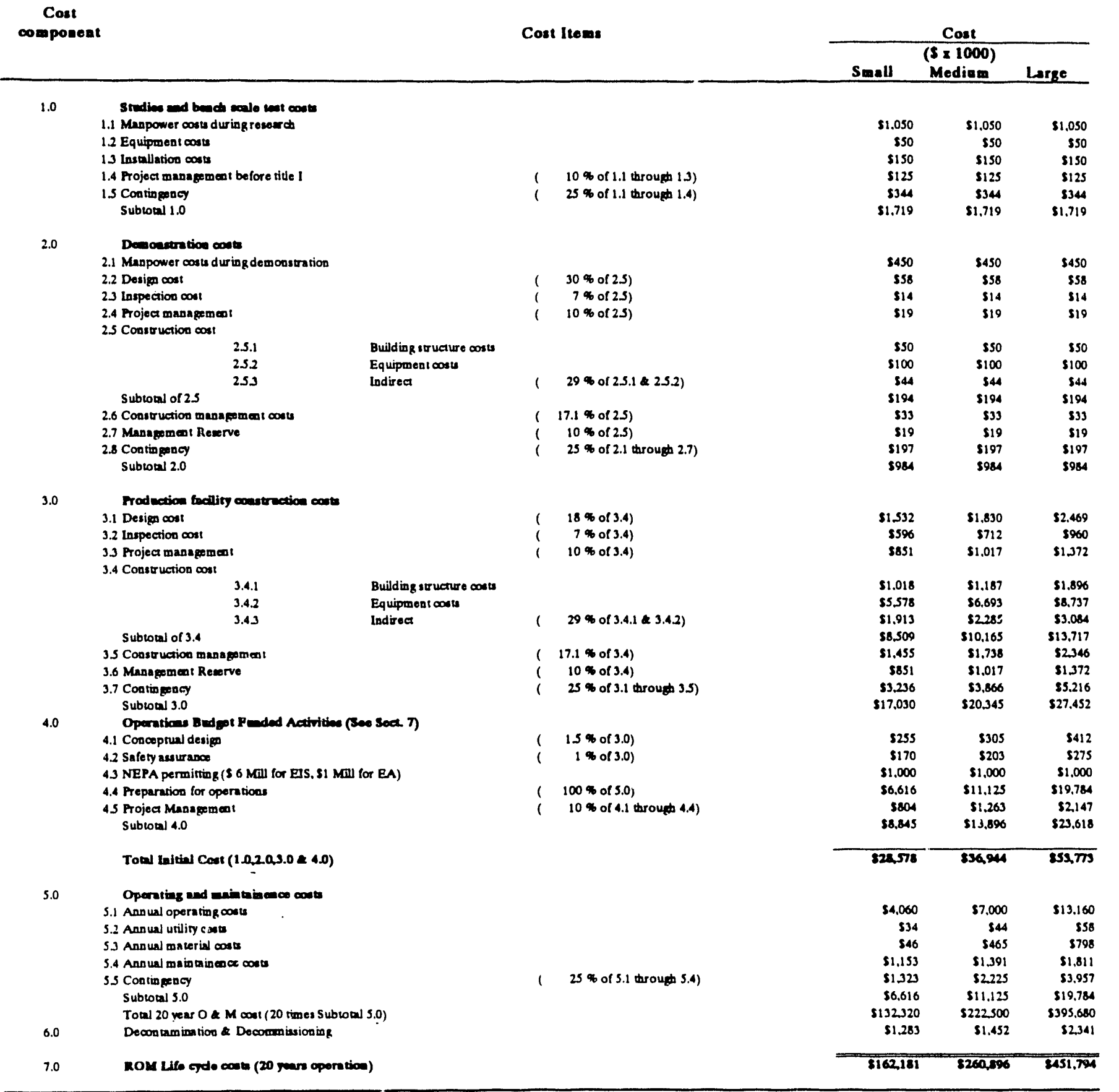


Table 8-4. PLCC estimate summary alpha-KLLW/LLMW solidification facility (cost module GA).

Cost

component

Cost Iteen:

Cost

1.2 Equipment costu

1.3 Installation cosss

1.4 Project manapement before tide I

1.5 Coutingency

$10 \%$ of 1.1 througt 1.3 )

Sublotal 1.0

(25\% of 1.1 throup 1.4)

Denonstration costs

2.1 Manpower costs during demonstration

2.2 Desigo cost

2.3 Inspection cost

2.4 Project manapement

2.5 Construction cost

\section{5 .1}$$
2.53
$$

Subtotal of 2.5

2.6 Construction management costs

2.7 Manapement Reserve

2.8 Contingency

Subrotal 2.0

Troduction facility conetrection cost:

3.1 Design coses

3.3 Project mana gement

3.4 Construction cost

$$
\begin{aligned}
& 3.4 .1 \\
& 3.4 .2 \\
& 3.4 .3
\end{aligned}
$$

Subcoul of 3.4

3.5 Construction management

3.6 Managemeol Reserve

3.7 Contingency

Subcoul 3.0

4.0

Oporations Badgot Proded Activition (Soe Sect T)

4.1 Concepruaid desigp

4.2 Safery assurance

4.3 NEPA permirting ( $\$ 6$ Mill for EIS. $\$ 1$ Mill for EA)

4.4 Proparation for operations

4.5 Project Managemear

Sublotal 4.0

Totw Initial $\operatorname{Cost}(1,0,2,0,3.0 * 4.0)$

Operatiag and mintuineasos costu

S.1 Annual operatug goous

5.2 Annual utility costu

5.) Annual material couts

5.4 Annun mainginence costs

5.5 Contingency

Subroml 5.0

Toth 20 yeas $O \&$ M cont ( 20 tumes Subtoral 9.0 )

6.0 Decontamimation Decommiasioning
Building structure costs

Equipmeat cosis

Endirect

$(29 \%$ of $2.5 .1 * 2.5 .2)$

( $17.1 \%$ of 2.5 )

( $10 \%$ of 2.5 )

( $25 \%$ of 2.1 through 2.7)

Buiding struchumo coses

Building struenuro costs

Equipment costs

Indirect

$29 \%$ of $3.4 .1 \times 3.4 .2)$

$(17,1 \%$ of 3.4$)$

$10 \%$ of 3.4 )

$25 \%$ of 3.1 through 3.5 )

( $15 \%$ of 3.0$)$

( 1 क of 3.0$)$

( $100 \%$ of 5.0$)$

( $10 \%$ of 4.1 through 4.1)

$\begin{array}{rrr}\$ 1.050 & \$ 1.050 & \$ 1.050 \\ \$ 50 & \$ 50 & \$ 50 \\ \$ 150 & \$ 150 & \$ 150 \\ \$ 125 & \$ 125 & \$ 125 \\ \$ 344 & \$ 344 & \$ 344 \\ \$ 1.719 & \$ 1.719 & \$ 1.719\end{array}$

5450

558

514

$\$ 19$

$\$ 50$

$\$ 100$

544

$\$ 194$

$\$ 33$

519

$\$ 984$

$\$ 450$

558

sso

$\$ 100$

S44

5194

533

519

5984

$\$ 3.947 \quad \$ 4.484 \quad \$ 5.640$

$\begin{array}{lll}\$ 1.579 & \$ 1.793 & \$ 2.259\end{array}$

$\$ 3.959 \quad \$ 4.468 \quad \$ 6.453$

$\$ 8.280 \quad \$ 9.434 \quad \$ 11.055$

$\begin{array}{lll}\$ 3.549 & \$ 4.032 & \$ 5.077\end{array}$

$\$ 15.788 \quad \$ 17.934 \quad \$ 22.585$

$\begin{array}{lll}\$ 2.700 & \$ 3.067 & \$ 3.862\end{array}$

$\$ \$ \$ 1.579 \quad \$ 1.793 \quad \$ 2.259$

$\$ 6.280 \quad 57,133 \quad 58,983$

$\begin{array}{lll}\$ 32.978 & \$ 37,459 & \$ 47.175\end{array}$

$\$ 495 \quad \$ 562 \quad \$ 705$

$\$ 330 \quad \$ 375 \quad \$ 472$

$\$ 1.000 \quad \$ 1.000 \quad \$ 1,000$

$\begin{array}{lll}\$ 7.640 & \$ 12.674 & \$ 17.793\end{array}$

$\$ \$ 947 \quad \$ 1.461 \quad \$ 1.997$

$\begin{array}{lll}\$ 10.412 & \$ 16.072 & \$ 21.970\end{array}$

$840,09356,234$

$\$ \$ .060 \quad \$ 7.420 \quad \$ 10.500$

$\$ 34 \quad \$ 48 \quad \$ 62$

$\$ 266 \quad \$ 664 \quad \$ 1,329$

$\begin{array}{lll}\$ 1.752 & \$ 2.007 & \$ 2.343\end{array}$

$\begin{array}{lll}\$ 1.528 & \$ 2535 & \$ 3.559\end{array}$

$\$ 7.640 \quad \$ 12.674 \quad \$ 17.793$

$\$ 1 \$ 2.800 \quad \$ 253,480 \quad \$ 3 \$ 5.860$

$\$ 1.779 \quad \$ 2.050 \quad \$ 3.624$ 


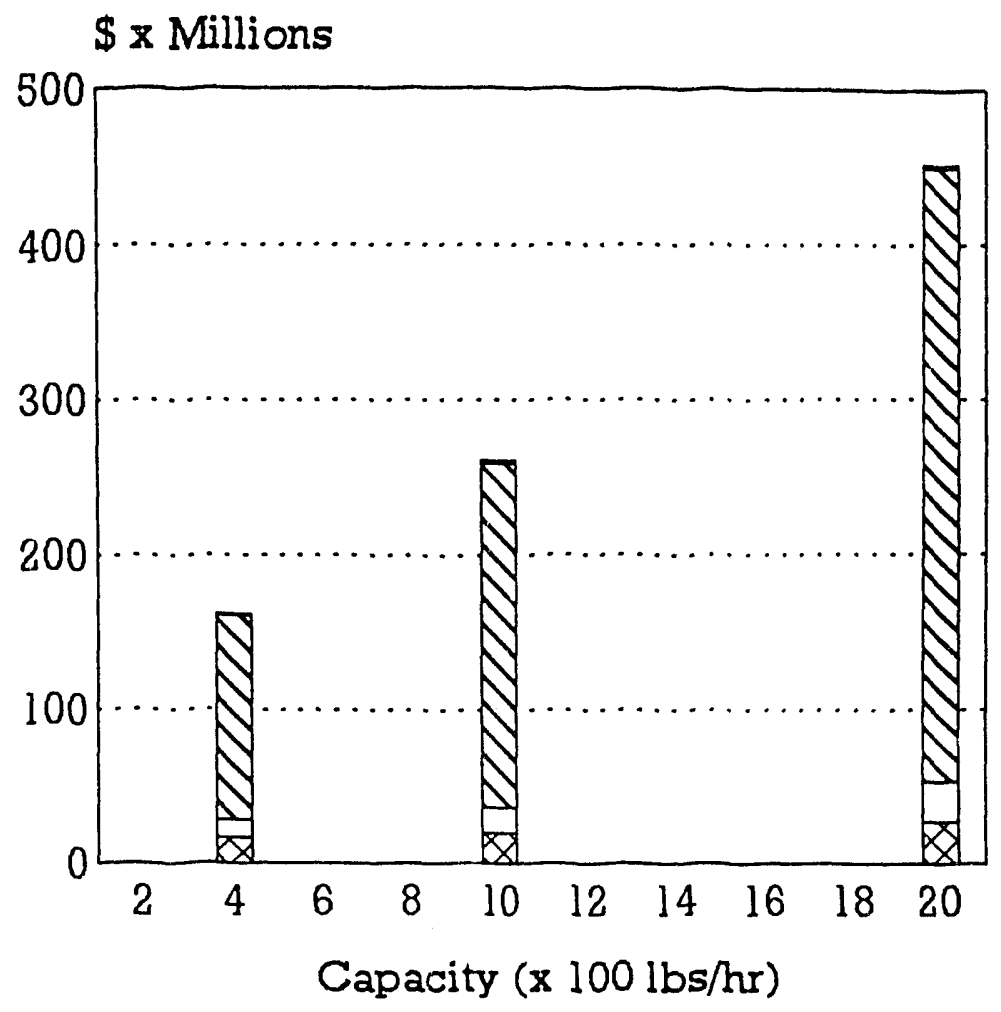

Deoontam \& Deoomm $\nabla_{20}$ Yrs O\& M Cosis $\square$ Oper. Bud Funded Aot. DProduction Fao. Const.

Figure 8-3. Cost versus capacity histogram for LLW/LLMW shredding and compaction facility (cost module GL).

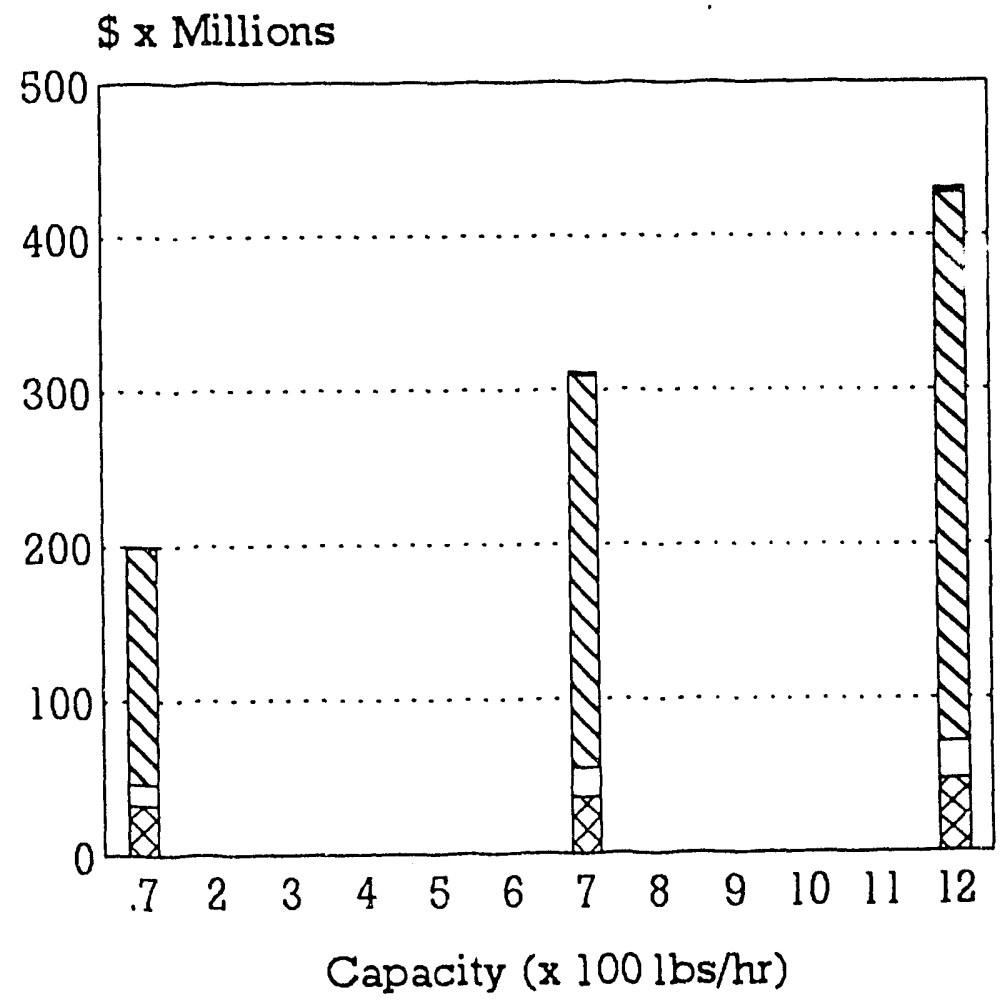

Decontam \& Decomm $\nabla_{20}$ Yrs O \& M Costs

Oper. Bud Funded Act. Xroduction Fac. Const.

Figure 8-4. Cost versus capacity histogram for alpha-LLW/LLMW shredding and compaction facility (cost module GA). 


\section{VITRIFICATION FACILITY (COST MODULES HL AND HA)}

\subsection{Basic Information}

The vitrification facility, shown in Figure 9-1, is used either in conjunction with the treatment front-end and back-end facilities (see cost modules $\mathrm{A}, \mathrm{B}, \mathrm{CA} / \mathrm{CL}, \mathrm{I}$, and JA/JL), or as an addition to existing facilities where similar functions are already available. Cost module $\mathrm{HA}$ is applicable to alpha-LLW/LLMW, and cost module HL is for LLW/LLMW. Unit operations are shown in Figure 9-2.

The facility is comprised of 10 main process unit operations designed to convert the incoming waste into a leach-resistant rock/glass-like material. Vitrified LLW/LLMW and alpha-LLW/LLMW waste that is based on iron-enriched basalt should meet both the LDR and DOE disposal requirements. $^{2,6}$ Secondary liquid and gaseous wastes are also treated. Secondary waste treatment by-products, such as off-gas scrubber sludge, are either fed to the melter or solidified in drums.

The vitrification facility processes noncombustible wastes such as inorganic sludge, ash, soil, brick, concrete, and other similar material. The facility can process solid waste of various shapes and forms. The size limitation imposed by the crusher/shredder is approximately $1 \mathrm{ft}^{3}$ and the incoming waste can contain as much as $10 \%$ combustibles. The facility is equipped with a predryer for processing wet sludge from its own secondary waste stream (i.e., wet sludges from the off-gas scrubber waste water). As a result, the facility can also treat a limited amount (up to 15\%) of additional inorganic wet sludge from outside sources.

\subsection{Technical Basis and Assumptions}

\subsubsection{Functional and Operational Description}

Specific operations include an input waste preparation and feed unit that crushes and shreds the incoming waste and transfers it to a melter unit operation. At the melter unit operation, a predryer, operating at approximately $300-400^{\circ} \mathrm{F}$, receives, dries, and feeds shredded waste and any sludge that must be vitrified to a vitrification furnace (or melter). Soil is added to the melter through a soil storage and feed unit operation. The furnace melts the soil/waste combination to form a molten slag. A slag cooling and packaging unit is used to receive the molten slag from the melter and cast it into containers. A transport device carries the slag containers to a drum capping and washing unit operation, where loose contamination is removed from the container surface with a high-pressure water spray.

The melter off-gas scrubber is equipped with a secondary combustion unit that completes the volatile gas destruction. An induced air blower moves the secondary combustor efflucnt through the air pollution control device that is designed to remove particulates, $\mathrm{SO}_{2}, \mathrm{HCl}$, and $\mathrm{NOx}$. A surge tank retains off-gas for reprocessing in the event of a process upset. Secondary liquid waste is processed by a liquid waste-treatment unit operation. This unit operation removes dissolved and suspended solids, both organic and inorganic, from the liquid waste. The facility recycles and reuses the treated wastewater resulting in zero discharge to the "nvironment. 
The sludge from the waste treatment unit is pumped to the melter predryer before vitrification. A solidification unit operation treats any sludge that cannot be vitrified. At the solidification unit, the sludge is mixed with a binder, such as Portland cement, and transferred to a drum. A predetermined ratio is used to produce a stabilized waste. The filled container is moved to a capping and washing unit operation, where the drum is capped and loose contamination is removed from the container surface by high-pressure water spray.

The containerized vitrified waste and drummed solidified waste drums are the main output from this cost module. These are ready for processing through radioassay and final certification, which is included in the back-end support facility.

\subsubsection{Facility Integration}

Major facility inputs include waste from the open, dump, and sort facility (cost module CA or $\mathrm{CL}$ ) and from the generator sites, as well as soil that is mined. Major O\&M purchased materials are consumables such as personal protective equipment, laboratory material, binder, soil, and disposable containers.

Major facility outputs are containerized, vitrified, and solidified LLW/LLMW and alphaLLW/LLMW, which are transported to a back-end supjort facility (see cost module I). Treated offgas is discharged into the atmosphere.

\subsection{Cost Bases, Assumptions, and Assessments}

General cost bases and assumptions are given in Appendix A. Facility specific items are discussed below.

- $\quad$ Estimated operating staff are shown in Table 9-1.

- Metal sizing and preparation (shredders), melter and its off-gas, scrubber, and solidification unit are the major equipment capital cost items.

- Cost for the preparation and feed unit are based on vendor quotes for shredders, conveyors, and dust collection equipment.

- Melter prices are based on budgetary quotes received from two vendors (Callidus Technologies and Retec).

- Callidus Technologies provided budgetary quotes for the various off-gas scrubbers.

- The selected solidification unit operation is manufactured by Stock Equipment Company, Chagrin Falls, Ohio. This suppliers provided a quote based on a unit similar to that sold to the DOE for installation at Savanna River Site.

- Small, medium, and large facility capacities and unit costs are shown in Table 9-2. 


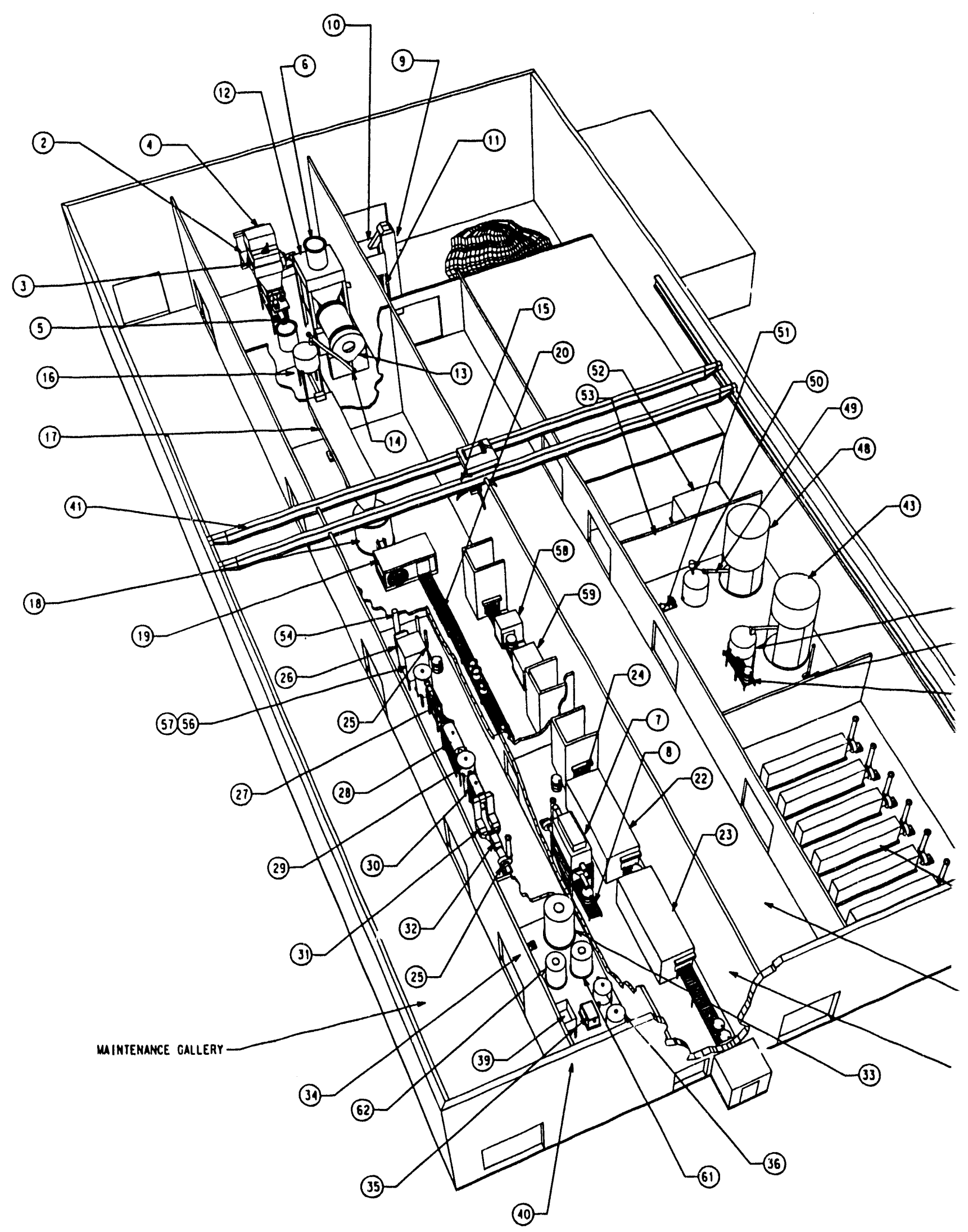

VITRIFICATION FACII TOP PERSPECTIVE •

Figure 9-1. Typical arrangement for alpha-LLW/LLMW vitrification facility. 


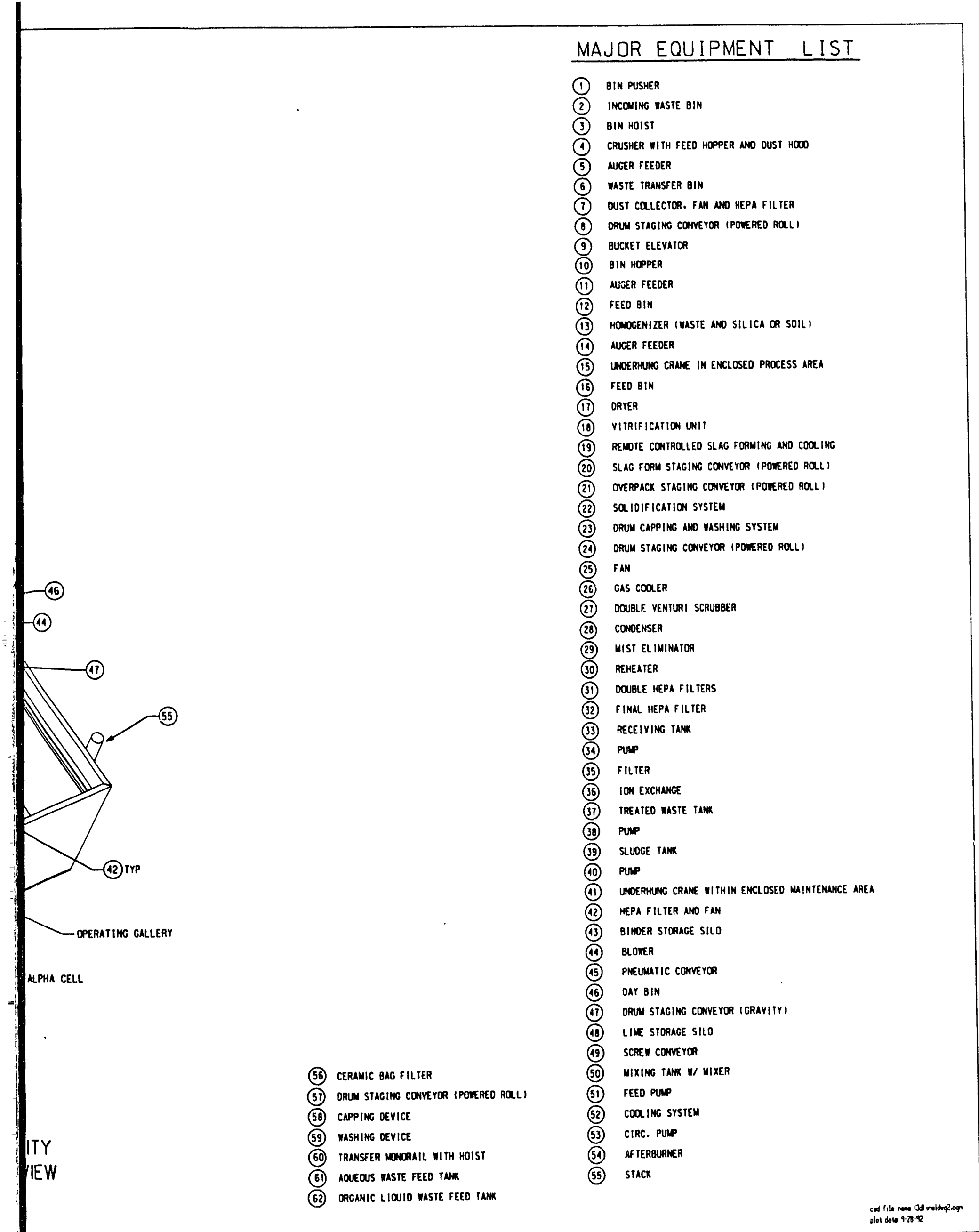




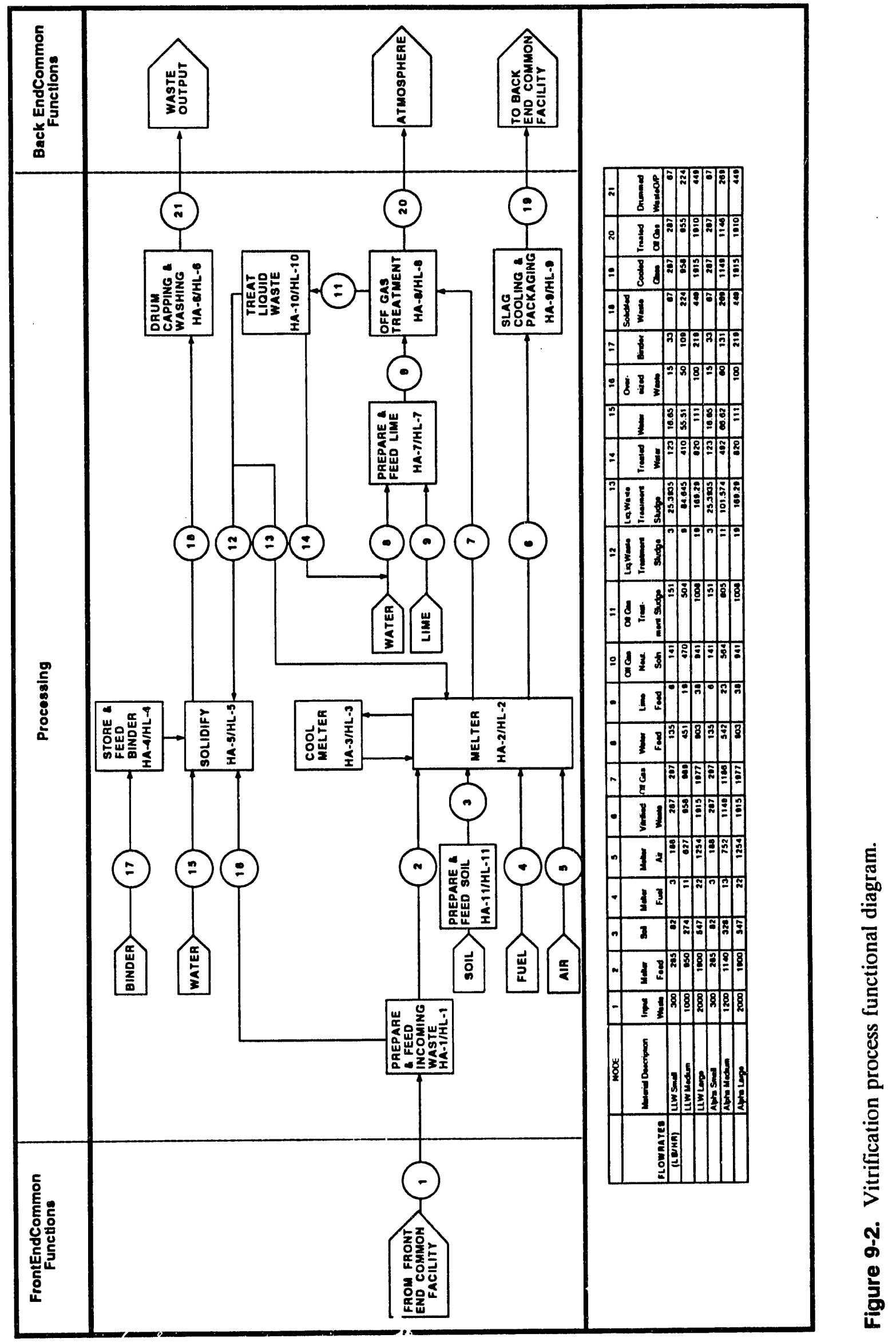


Table 9-1. Estimated operating staff for vitrification facility (cost module $\mathrm{H}$ ).

\begin{tabular}{llccc}
\hline $\begin{array}{c}\text { Unit } \\
\text { operation }\end{array}$ & \multicolumn{1}{c}{ Description } & $\begin{array}{c}\text { Small } \\
(\text { FTE })\end{array}$ & $\begin{array}{c}\text { Medium } \\
(\text { FTE })\end{array}$ & $\begin{array}{c}\text { Large } \\
\text { (FTE) }\end{array}$ \\
\hline H-1 & Prepare and feed incoming waste & 4 & 6 & 10 \\
H-2 & Melter & 7 & 7 & 10 \\
H-3 & Cool melter & 0 & 0 & 0 \\
H-4 & Store and feed binder & 2 & 4 & 6 \\
H-5 & Solidify & 2 & 4 & 6 \\
H-6 & Drum capping and washing & 2 & 2 & 4 \\
H-7 & Prepare and feed lime & 2 & 4 & 4 \\
H-8 & Off-gas treatment & 2 & 4 & 7 \\
H-9 & Slag cooling and packaging & 4 & 4 & 7 \\
H-10 & Treat liquid waste & 2 & 4 & 7 \\
H-11 & Prepare and feed soil & 2 & 4 & 7 \\
H-12 & Electrical distribution and MCC & 2 & 4 & 4 \\
H-13 & Heating, ventilation, and exhaust & 4 & 4 & 4 \\
H-14 & Other equipment & 6 & 10 & 14 \\
& Total & 41 & 61 & 90 \\
\hline
\end{tabular}

Table 9-2. Capacities and cost information for vitrification facility (cost module HL and HA). ${ }^{\mathrm{a}}$

\begin{tabular}{|c|c|c|c|c|c|c|c|c|}
\hline Mod. & Module & Facility & Life Cycle Cost & Capacity & Unit Cost & Capacity & Cap(Tot Vol) & Un \\
\hline & Descriptior. & & $(\$ \times 1000)$ & $(\mathrm{lbs} / \mathrm{hr})$ & $(\$ / 1 b)$ & $(\mathrm{ft} 3 / \mathrm{hr})$ & $(\mathrm{ft} 3 \times 1000)$ & $(\$ / f t 3)$ \\
\hline & notinn & $\mathrm{Amn}$ & & & & & & \\
\hline$t h$ & callui & sman! & $\$ 316,401$ & 300 & $\$ 13.08$ & 9 & 691 & $\$ 45$ \\
\hline & Vitrification & Medium & $\$ 430,303$ & 1,000 & $\$ 5.34$ & 29 & 2,304 & .76 \\
\hline & Vitrification & Large & $\$ 587,311$ & 2,000 & $\$ 3.64$ & 57 & 4,608 & $\$ 127.45$ \\
\hline A & Vitrification & Small & $\$ 359,866$ & 300 & $\$ 14.88$ & 9 & 691 & $\$ 520.64$ \\
\hline$A$ & Vitrification & Medium & $\$ 490,069$ & 1.200 & $\$ 5.06$ & 34 & 2,765 & $\$ 177.25$ \\
\hline 1. & Vitrification & Large & $\$ 655,339$ & 2,000 & $\$ 4.06$ & 57 & 4,608 & $\$ 142.22$ \\
\hline
\end{tabular}

a. Average density used is $35 \mathrm{lbs} / \mathrm{ft}^{3}$ 


\subsection{Cost Summaries}

Cost summaries for the LLW/LLMW and alpha-LLW/LLMW vitrification facilities are shown in Tables 9-3 and 9-4. Figures 9-3 and 9-4 contain a histogram of the PLCC estimates. 
Table 9-3. PLCC estimate summary for LLW/LLMW vitrification facility (cost module HL).

Cost component

Cost Items

Cost

\begin{tabular}{c} 
Cost \\
\hline Small $\begin{array}{c}(\$ \times 1000) \\
\text { Medium }\end{array}$ Large
\end{tabular}

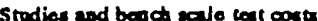

1.1 Manpower cosis during resensch

1.2 Equipment cosis

1.4 Project masngemest before tille 1

is Contingeng

$10 \%$ of 1.1 through 1.3$)$

( $25 \%$ of 1.1 (through 1.4$)$

Sublotal 1.0

2.0

Descosertration cost:

2.1 Maspower costs during demonstration

2.2 Design cost

23 Laspectiou cost

2.4 Project management

2.5 Construetion cost

$$
\begin{aligned}
& 2.5 .1 \\
& 2.5 .2 \\
& 2.5 .3
\end{aligned}
$$

Subtotal of 2.5

2.6 Construction managemeat conts

2.7 Management Rexerve

2.8 Contingency

Subwoal 2.0

3.0

Production facility construction conts

3.1 Design cost

3.2 Inspection cost

33 Project management

3.4 Construetion cost

$$
3.4 .1
$$

Subcotal of 3.4

3.5 Construetion masagemen

3.6 Management Reserve

3.7 Contingency

Subloal 3.0

Operations Bodgot Panded Activitioe (Seo Soct 7 )

4.1 Conceprual desigo

4.2 Safery assuradoce

4.3 NEPA permining ( 56 Mill for Ers, S1 Mill for EA)

4.4 Preparation for operations

4.5 Project Managemeot

Sutcoal 4.0

Toual Initial Cont $(1.0,2.0,5.0 * 4.0)$

Equipment cosis

lodirect

$(29 \%$ of $2.5 .1 * 2.5 .2)$

$(17.1 \%$ of 2.5$)$

( $10 \%$ of 2.5 )

( $25 \%$ of 2.1 through 2.7)

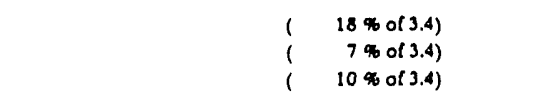

Building structure costs

Equipment costs

Indirect

( $\quad 29 \%$ of $3.4 .1 \& 3.4 .2)$

( $17.1 \%$ of 3.4$)$

( $10 \%$ of 3.4 )

( $25 \%$ of 3.1 through 3.5 )

( $1.5 \%$ of 3.0$)$

$(1 \%$ of 3.0$)$

( $100 \%$ of 5.0$)$

( $10 \%$ of 4.1 through 4.4)

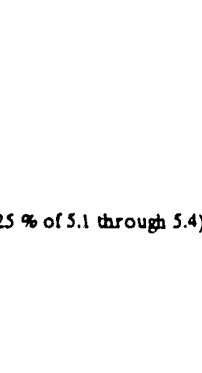

$\$ 3.600 \quad \$ 3.600 \quad \$ 3.600$

$\$ 650 \quad \$ 550 \quad \$ 650$

S450 S450 \$450

$\$ 1.238 \quad \$ 1.238 \quad \$ 1.238$

52.00000

$\$ 2.400 \quad \$ 2.400 \quad \$ 2.400$

$\$ 167 \quad 5554 \quad 5554$

$\$ 39 \quad \$ 129 \quad \$ 129$

$\$ 56 \quad \$ 185 \quad \$ 185$

$\$ 80 \quad \$ 180 \quad \$ 180$

$\$ 350 \quad \$ 1.250 \quad \$ 1.250$

$\begin{array}{lrr}s 350 & \$ 1.250 & \$ 1.250 \\ s: 25 & \$ 415 & \$ 415\end{array}$

s5s5 \$1.845 $\$ 1.845$

$595 \quad 5315 \quad 5315$

$\$ 56 \quad \$ 185 \quad 5185$

$\$ 842 \quad \$ 1.403 \quad \$ 1.403$

$\begin{array}{lll}\$ 4.210 & \$ 7.016 & \$ 7.016\end{array}$

$\begin{array}{lll}\$ 4.378 & 55.296 & \$ 6.627\end{array}$

$\begin{array}{lll}\$ 1.703 & \$ 2.059 & \$ 2.577\end{array}$

$\$ 2.432 \quad \$ 2.942 \quad \$ 3.682$

$\$ \$ \$ 3.203 \quad \$ 3.947 \quad \$ 5.778$

$\$ 1 \% .650 \quad \$ 18.859 \quad 522.764$

$\$ 5.468 \quad \$ 6.614 \quad \$ 8.277$

$\begin{array}{lll}\$ 24.323 & \$ 29.420 & \$ 36.819\end{array}$

$\$ 4.159 \quad \$ 5.031 \quad \$ 6.296$

$\$ 2.432 \quad \$ 2.942 \quad \$ 3.682$

$\$ \$ \$, 249 \quad \$ 11.187 \quad \$ 14.000$

$\begin{array}{lll}\$ 48.676 & \$ 58.877 & \$ 73.683\end{array}$

$5730 \quad 5883 \quad 51,105$

$\begin{array}{lll}\$ 487 & \$ 589 & \$ 737\end{array}$

$\$ 6.000 \quad \$ 6.000 \quad \$ 6.000$

$\$ 11.623 \quad \$ 16.338 \quad \$ 22.956$

$\$ 1.884 \quad \$ 2.381 \quad \$ 3.080$

$\begin{array}{lll}\$ 2.0 .724 & \$ 26.191 \quad \$ 33.878\end{array}$

$\begin{array}{lll}\$ 79,798 & \$ 98,272 & \$ 120,765\end{array}$

$\begin{array}{lrr}55,740 & 58.543 \quad \$ 12,600\end{array}$

$\$ 226 \quad \$ 57: \quad \$ 836$

$\$ 130 \quad \$ 84 \quad \$ 271$

$\$ 3.202 \quad \$ 3.871 \quad \$ 4.658$

$\$ 2325 \quad \$ 3.268 \quad \$+\$ 391$

$\$ 11.823 \quad \$ 16.338 \quad \$ 22.956$

$\$ 332.160 \quad \$ 326.760 \quad \$ 459.120$

$\$ 4.143 \quad \$ 5.271 \quad \$ 7.426$

6.0 Decontamiontios \& Decommissioning

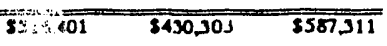


Table 9.4. PLCC estimate summary for alpha-LLW/LLMW vitrification facility (cost module HA).

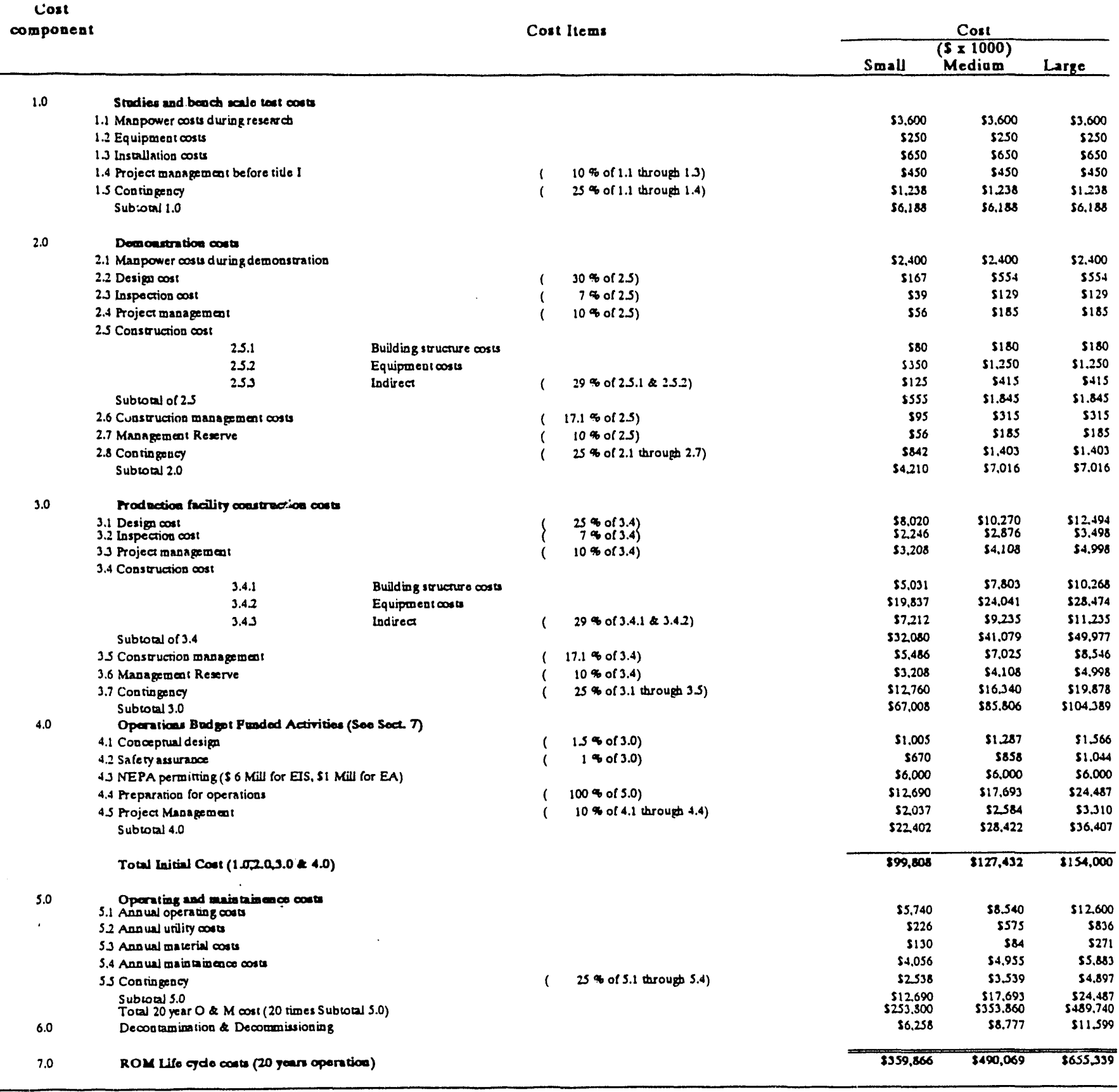




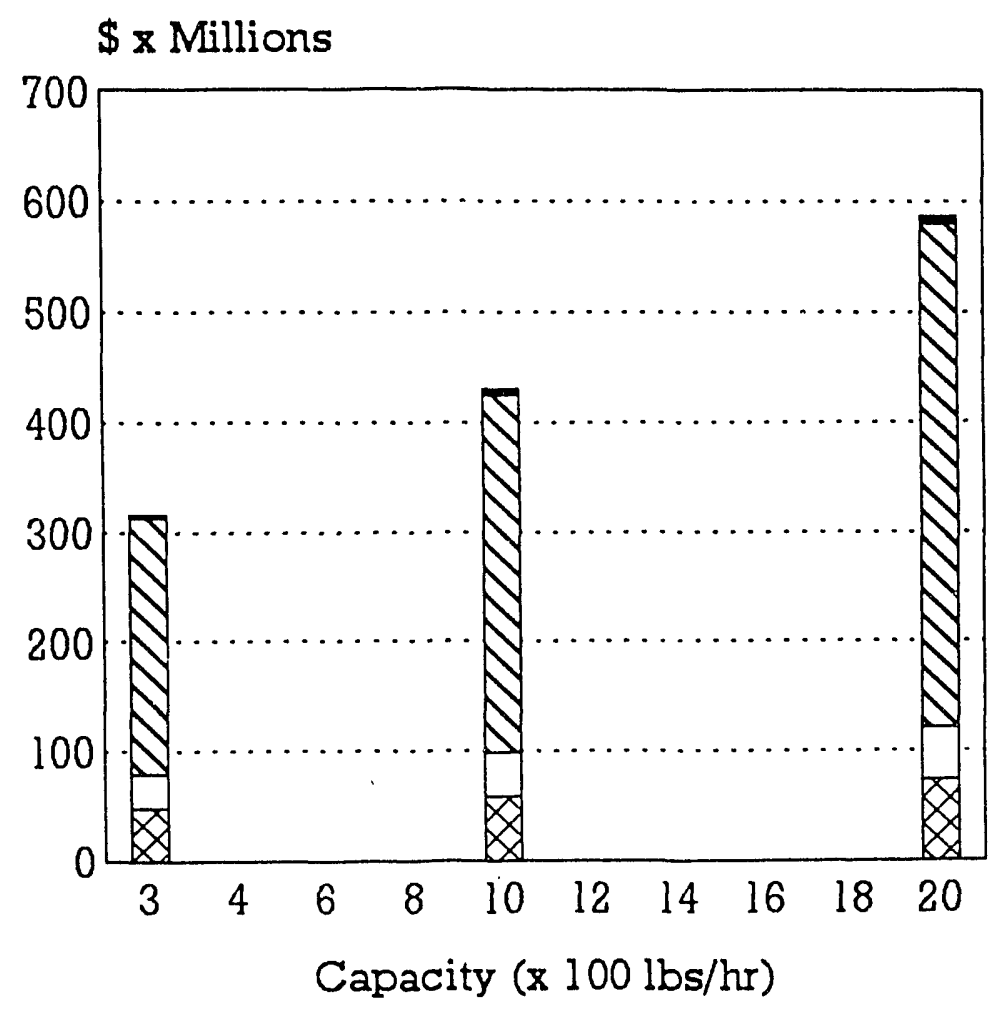

Deoontam \& Dooomm $\nabla_{20}$ Yrs $0 \&$ M Costs $\square$ Oper. Bud. Funded Aot. Broduction Fac. Const.

Figure 9-3. Cost versus capacity histogram for LLW/LLMW shredding and compaction facility (cost module $\mathrm{HL}$ ).

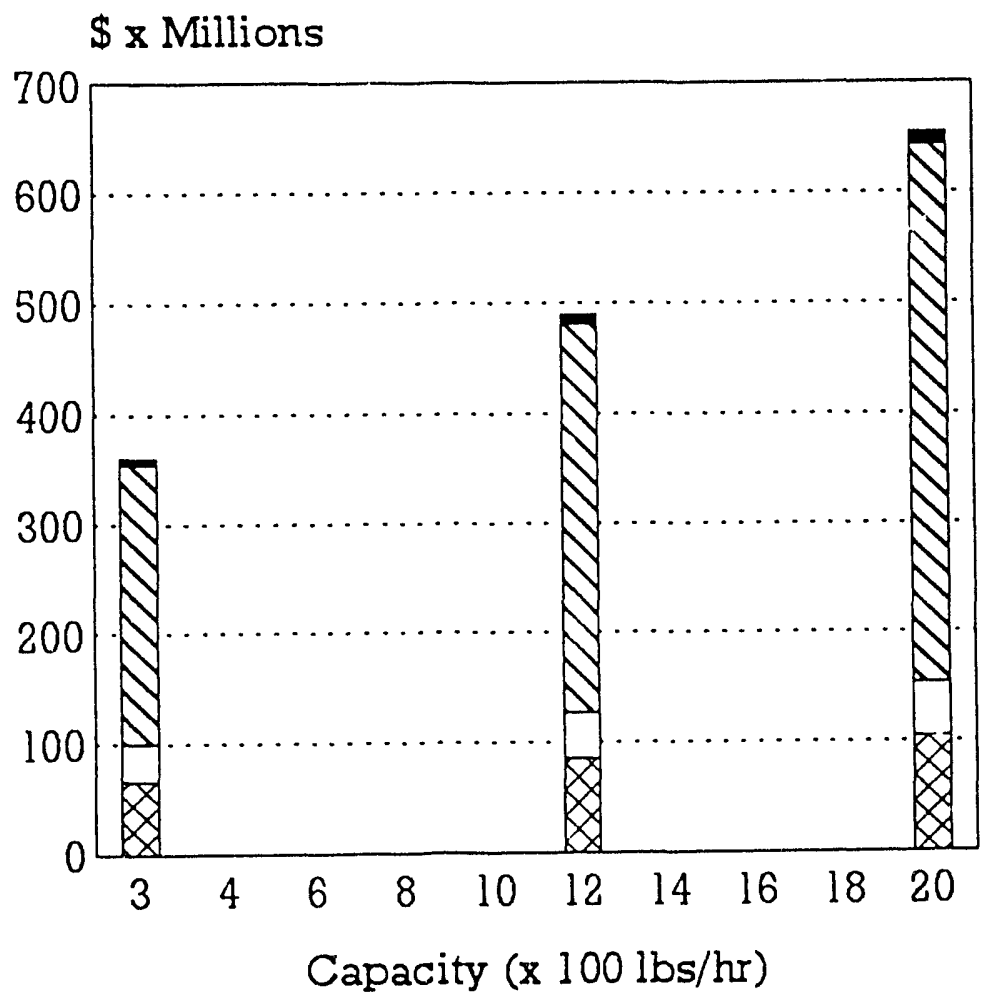

Decontam \& Docomm $\triangle 20$ Yrs 0 \& M Costs $\square$ Oper. Bud. Funded Aot. Droduotion Fac. Const.

Figure 9-4. Cost versus capacity histogram for alpha-LLW/LLMW shredding and compaction facility (cost module HA). 


\section{CERTIFICATION/SHIPPING FACILITY (COST MODULE I)}

Certification/shipping facility is the same for LLW/LLMW and alpha-LLW/LLMW and LLW/LLMW waste treatment facilities. There are only minor differences in the assay/certification equipment that do not affect the overall PLCC estimates. Unit operations are given in Figure 10-1.

\subsection{Basic Information}

The certification/shipping facility consists of three unit operations: incoming material storage, assay/certificacion, and truck loading. This facility receives packaged waste containers from treatment facilities (cost modules DA, DL, EA, EL, FA, FL, GA, GL, HA and HL), and provides temporary storage, radiological and physical characterization of the waste, and shipment of the containers.

The certification/shipping facility is used in conjunction with treatment facilities when the required functions are not available at existing facilities. The facility includes all equipment needed for certification of the waste in compliance with the transportation, storage, and disposal regulations and requirements.

\subsection{Technical Bases and Assumptions}

\subsubsection{Functional and Operational Description}

Packaged waste containers arrive from treatment facilities on conveyors, carts, or other transport devices. Containers are removed from the transport devices and placed in a staging area. The containers are then visually examined, tagged, logged, recorded, and sent to an assay/certification unit operation. In this unit operation, the containers are examined by radioassay devices to allow both alpha and gamma radioactivity classification in accordance with the transportation, storage and disposal criteria. Various devices, such as PAN counting and SGS instruments, may be used.

Next, the containers are weighed and measured to determine waste density. The existence of materials restricted by transportation, storage, and disposal is determined by nondestructive examinations such as ultrasonic instruments or a RTR device. After examination, each container is labeled and its properties are logged and recorded into a computerized database. After inspection, the container is moved to a temporary storage area until they are ready for shipment to an interim storage or disposal facility. Containers that do not meet the transportation dose criteria are shipped in a truck equipped with a shield overpacks.

The shipping/certification facility is equipped with a bridge crane and a forklift. Containers can be loaded onto flat-bed trailer or van trucks. Containers can also be loaded into large transportation overpacks (e.g., TRAMPAC). This facility is designed to be installed contiguous to a treatment facility.

To allow year-round operations and minimize the effects of a potential spill, it is assumed that the certification/shipping operations will take place indoors. 


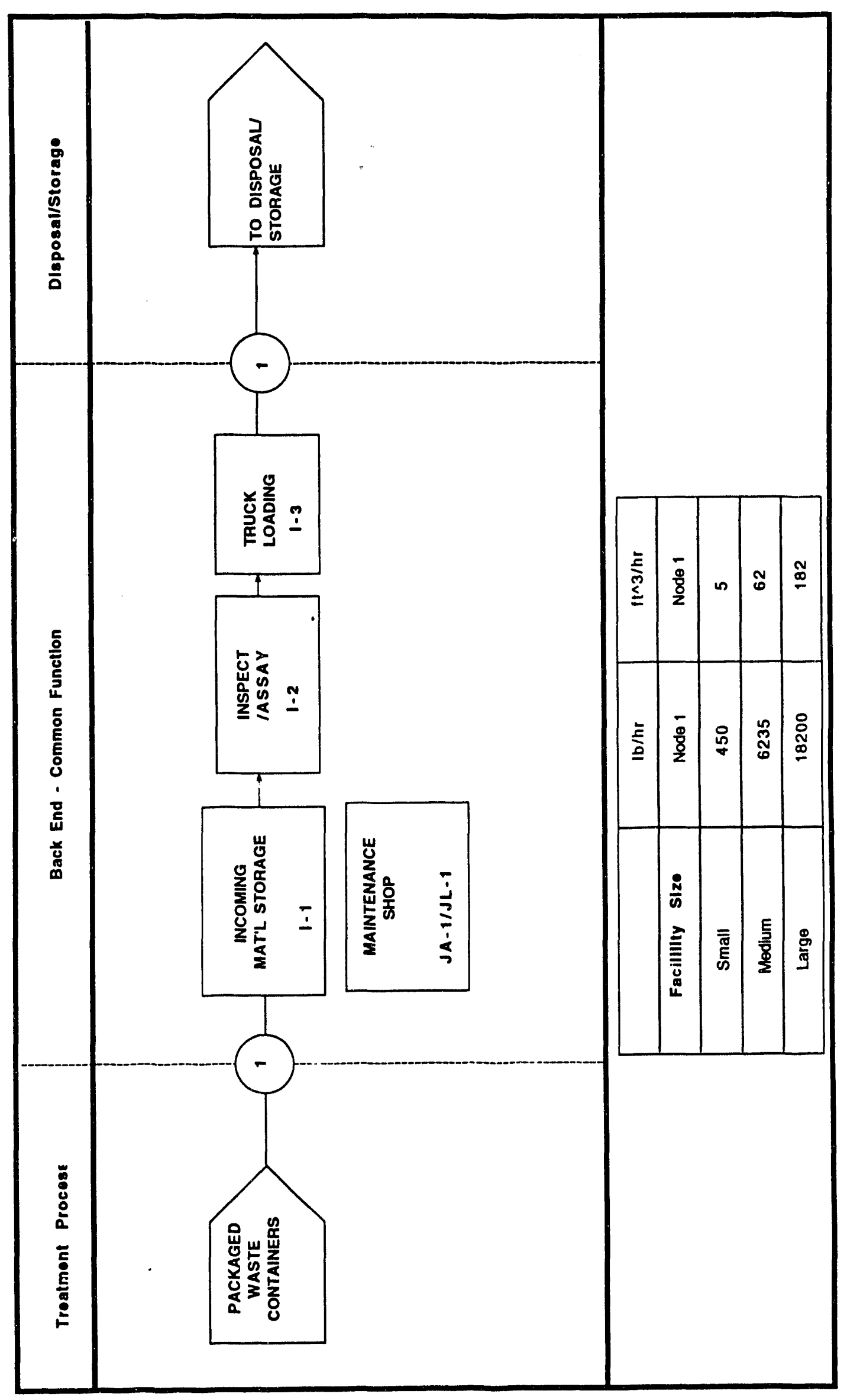

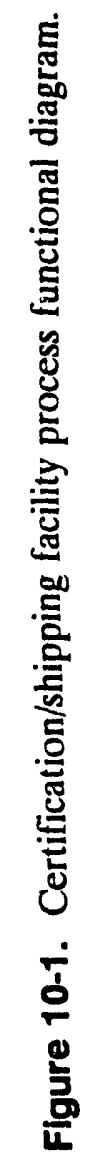




\subsubsection{Facility Integration}

Facility input includes packaged waste from treatment facilities. Input from the site includes utilities, service water, normal and emergency power, and communications. O\&M consumables including personal protective equipment must be purchased. Facility output includes truck shipments of containerized LLW/LLMW or alpha-LLW/LLMW to storage and disposal facilities.

\subsection{Cost Bases, Assumptions, and Assessments}

General cost bases and assumptions are given in Appendix A. Facility specific items are discussed below:

- Major equipment capital cost items for this facility are a 20 ton bridge crane, alpha assay, gamma assay, and RTR units. The equipment estimates were obtained as discussed in Section 4 of this report.

- Estimated operating staff are shown in Table 10-1.

- Small, medium, and large facility capacities and unit costs are shown in Table 10-2.

\subsection{Cost Summaries}

Cost summaries for the LLW/LLMW and alpha-LLW/LLMW receiving and unloading cost facilities are shown in Table 10-3. Histograms for cost versus capacity are given in Figurc 10-2.

Table 10-1. Estimated operating staff for certification/shipping facility (module I).

\begin{tabular}{clccc}
\hline $\begin{array}{c}\text { Unit } \\
\text { operation }\end{array}$ & \multicolumn{1}{c}{ Description } & $\begin{array}{c}\text { Small } \\
\text { (FTE) }\end{array}$ & $\begin{array}{c}\text { Medium } \\
\text { (FTE) }\end{array}$ & $\begin{array}{c}\text { Large } \\
\text { (FTE) }\end{array}$ \\
\hline I-1 & Incoming material storage & 0 & 0 & 0 \\
I-2 & Inspect and assay & 4 & 10 & 20 \\
I-3 & Truck loading & 4 & 10 & $\underline{20}$ \\
& Total & 8 & 20 & 40 \\
\hline
\end{tabular}

Table 10-2. Capacities and cost information for certification/shipping facility (cost module I). ${ }^{a}$

\begin{tabular}{|c|c|c|c|c|c|c|c|c|}
\hline Mod & Module & Facility & Lifo Cycle Cos & Capacity & Unit Cost & Capacity & $\mathrm{Cap}$ (Tot Vol) & Unit Cost \\
\hline & Description & & $(\$ \times 1000)$ & $(\mathrm{lbs} / \mathrm{hr})$ & $(\$ / 1 b)$ & $(f t 3 / h r)$ & $(f t 3 \times 1000)$ & $(\$ / f t 3)$ \\
\hline & & & & & & & & \\
\hline & $\mathrm{O}$ & Small & $\$ 69,315$ & 450 & $\$ 1.91$ & 4 & 324 & $\$ 213.94$ \\
\hline & $n t$ & Medium & $\$ 127,960$ & 6,235 & $\$ 0.25$ & 56 & 4,489 & $\$ 28.50$ \\
\hline & Cert./Shipment & Large & $\$ 239,201$ & 18,200 & $\$ 0.16$ & 163 & 13,104 & $\$ 18.25$ \\
\hline
\end{tabular}

a. Average density used is $112 \mathrm{lbs} / \mathrm{ft}^{3}$. 
Table 10-3. PLCC estimate summary for treatment certification/shipping facility (cost module I).

Cost

component

Cost Items

Cost

\begin{tabular}{cc} 
Cost \\
\hline Small $\quad \begin{array}{l}(\text { S } \times 1000) \\
\text { Mediam }\end{array}$ Large
\end{tabular}

Stodies and besch scale lout costs

1.1 Manpower costs during research

1.2 Equipmedt costs

1.3 Insmallation costs

1.4 Project mana pemeni before title I

is Coatingear!

$10 \%$ of 1.1 through 1.3$)$

Subrotal 1.0

( $25 \%$ of 1.1 through 1.4)

Demonatration conts

2.1 Manpower costs during demonstration

2.2 Design cost

2.3 Inspection cost

2.4 Project mana gement

2.5 Construction cost

$10 \%$ of 2.5$)$

Building soructure costs

Equipmeat costs

2.5 .2

Indirea

$(29 \%$ of $2.5 .1 * 2.5 .2)$

Subrotal of 23

2.6 Construction mankgemeal costs

2.7 Management Reserve

2.8 Contingency

Subions 2.0

( $17.1 \%$ of 2.5$)$

( $10 \%$ of 25 )

( $25 \%$ of 2.1 through 2.7)

Frod betion feclity constrection conts

3.1 Design cost

3.2 Inspection cost

3.3 Project management

3.4 Construction cost

$8 \%$ of 3.4

$\begin{array}{rr}(18 \% \text { o( } 3.4) \\ 1 & 7 \% \text { of }(3.4)\end{array}$

Buidding strueture cosis

Equipmedicosts

Lodirea

$(29 \%$ of $3.4 .1 * 3.4 .2)$

Sublotal of 3.4

3.4 .1
3.4 .2
3.4 .3

3.5 Construetion managemast

3.6 Manapement Reserve

3.7 Contingency

Subroaj 3.0

4.0

Opantions Budfor Pended Activition (Soo Sect 7$)$

4.1 Conceprual desigo

4.2 Safery asuunoce

43 NEPA permitting (\$ 6 Mill for EIS. $\$ 1$ Mall for EA)

4.4 Preparation for operatioos

45 Project Masagemeat

Sublotal 4.0

Total Initial Cost $(1.0,20,3.0<4.0)$

Operatiog and anintainemee conts

5.1 Annual operating coses

5.2 Annual utidity cols

S3 Anoual material cosa

S.4 Annual maintainerec costs

S.S Contingency

Subroul 5.0

$(17.1 \%$ of 3.4$)$

$10 \%$ of 3.4$)$

(. $25 \%$ of 3.1 through 3.5 )

Tutal 20 year $O$ \& $M \cos t$ ( 20 rimes Subrotal 4.0)

6.0

Decontamination \& Decomoission: 'ng

$3 \%$ of 3.0

$1 \%$ of 3.0 )

( $100 \%$ of 5.0 )

( $10 \%$ of 4.1 through 4.4 )

$\begin{array}{lll}\text { so } & \text { so } & \text { so } \\ \text { so } & \text { so } & \text { so } \\ \text { so } & \text { so } & \text { so } \\ \text { so } & \text { so } & \text { so } \\ \text { so } & \text { so } & \text { so } \\ \text { so } & \text { so } & \text { so }\end{array}$




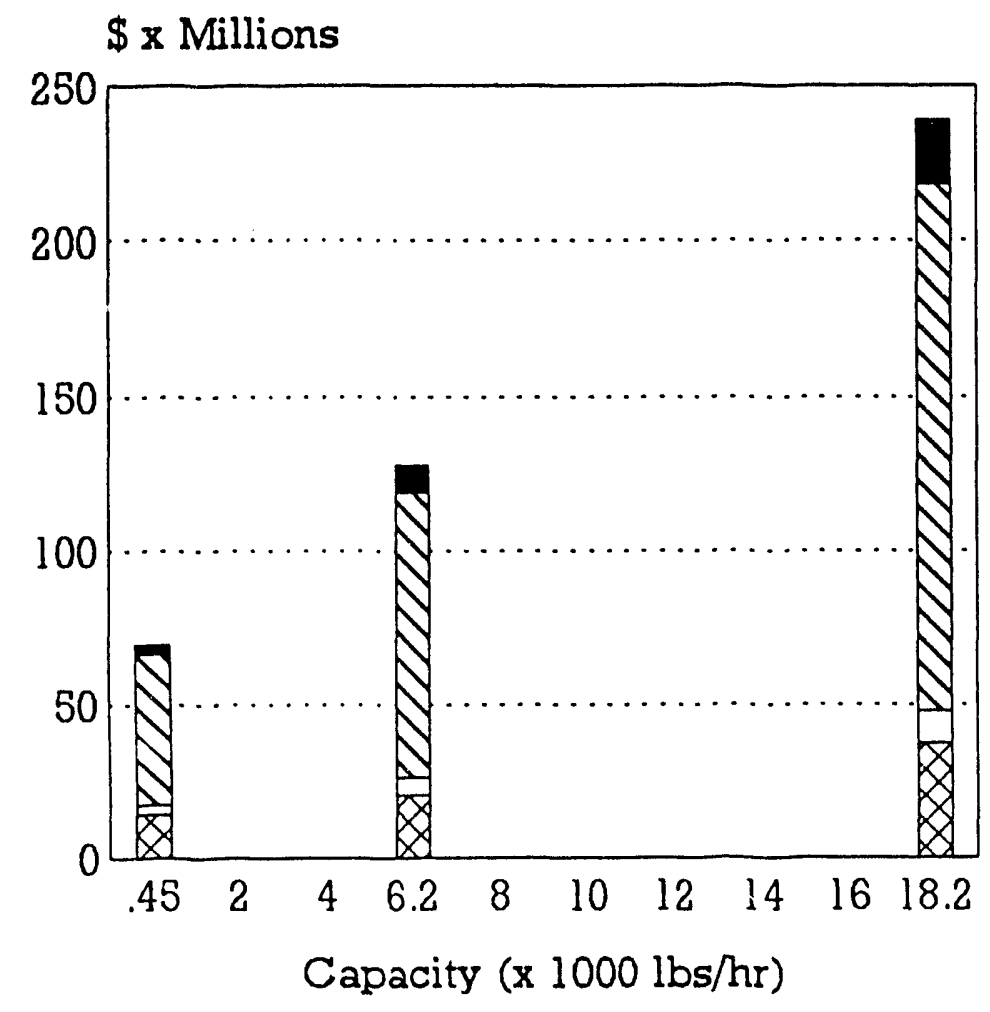

Dooonlam \& Dooomm. $\nabla_{20}$ Yrs $0 \&$ M Costs $\square$ Oper. Bud. Funded Aol. Xroduation Fac. Const.

Figure 10-2. Cost versus capacity histogram for treatment certification/shipping facility (cost module I). 


\section{TREATMENT MAINTENANCE FACILITY (COST MODULES JL AND JA)}

The maintenance shop is the same for alpha-LLW/LLMW and LLW/LLMW TSD facilities with the exception that the alpha-LLW/LLMW facility includes a mock-up shop.

\subsection{Basic Information}

The maintenance facility is equipped with a failed equipment receiving and repair building housing macninery and tools. This facility is used in conjunction with the treatment facilities when such function is not available at the existing facilities. The maintenance shop costs assumes repair of components contaminated with low-level radioactivity but not alpha-emitters. Components contaminated with alpha farticles must be decontaminated in the alpha maintenance galleries before they are brought into the maintenance shop. Cost module JA has remote component mock-up area.

\subsection{Technical Bases and Assumptions}

Contaminated failed equipment and parts arrive at the shop in transfer carts. Parts are removed from the transport carts and placed in a decontamination area where high pressure spray or other techniques are used to remove any loose contamination. After cleaning and decontamination, components are moved to maintenance tables. Maintenance machinery and tools are used as needed. The shop includes an overhead and a jib crane for material handling. A paint booth is also included.

\subsection{Cost Bases, Assumptions, and Assessments}

Major equipment capital cost items are milling, sanding, and lathe machinery and tools. Costs for all machinery and equipment including the cranes are based on industrial (nonradioactive) applications.

- $\quad$ Estimated operating staff are shown in Table 11-1.

- Back-end facility capacities and unit costs are shown in Table 11-2.

\subsection{Cost Summaries}

Cost summaries for the cost modules are shown in Tables 11-3 and 11-4. Histograms for cost versus capacity are given in Figures 11-1 and 11-2. 
Table 11-1. Estimated operating staff for back-end treatment facilities (cost module J).

\begin{tabular}{clccc}
\hline $\begin{array}{c}\text { Unit } \\
\text { operation }\end{array}$ & \multicolumn{1}{c}{ Description } & $\begin{array}{c}\text { Small } \\
\text { (FTE) }\end{array}$ & $\begin{array}{c}\text { Medium } \\
\text { (FTE) }\end{array}$ & $\begin{array}{c}\text { Large } \\
\text { (FTE) }\end{array}$ \\
\hline \multirow{2}{*}{$\mathrm{J}-1$} & Warehouse/maintenance & $\underline{7}$ & $\underline{15}$ & $\underline{30}$ \\
& Total & 7 & 15 & 30 \\
\hline
\end{tabular}

Table 11-2. Capacities and cost information for treatment maintenance facility (cost module JL and JA). ${ }^{a}$

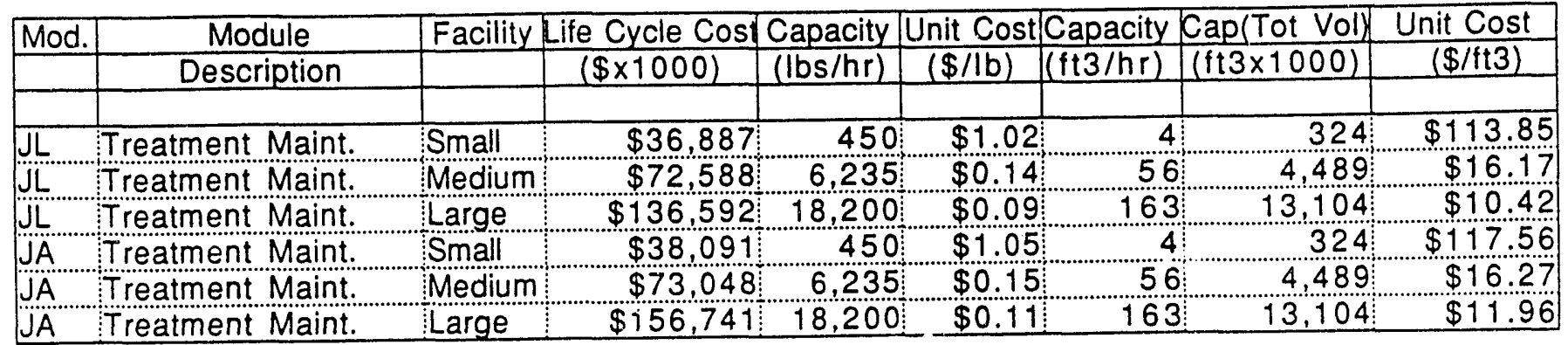

a. Average desity used is $112 \mathrm{lbs} / \mathrm{ft}^{3}$. 
Table 11-3. PLCC estimate summary LLW/LLMW treatment maintenance facility (cost module JL).

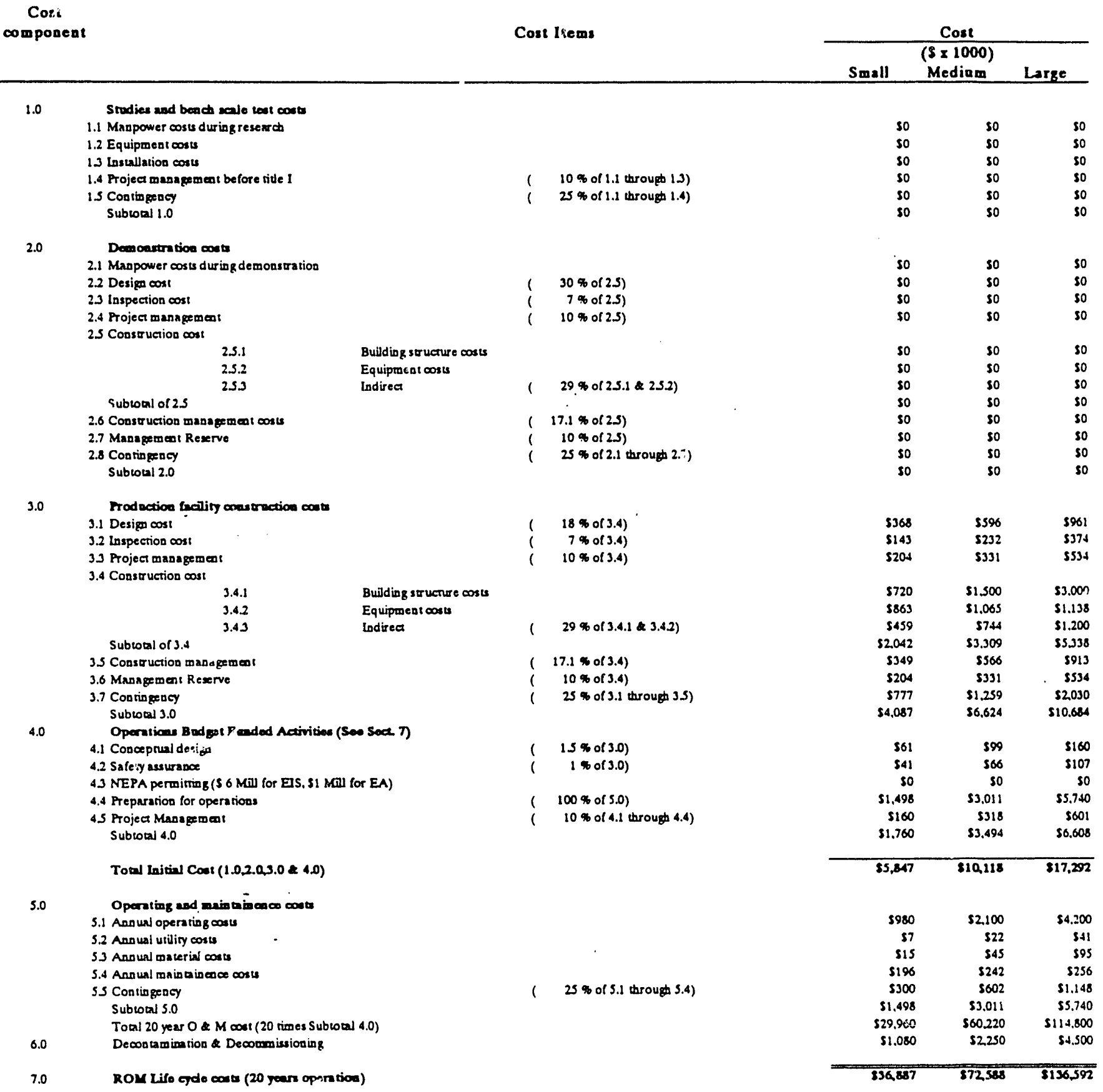


Table 11-4. PLCC estimate summary alpha-LLW/LLMW treatment maintenance facility (cost module JA).

Cost

component

Cost Items

Cost

S $\times 1000)$

Small

Mediam

Large

Strdies and beach acalo lost conts

1.1 Mnnopower costs during research

1.2 Equipment costs

1.3 Insullation costs

1.4 Project manngement before tile I

1.5 Contingency

$\%$ of 1.1 through (1.3)

Subrotal 1.0

( $25 \%$ of 1.1 through 1.4 )

Demonertiontion cost

2.1 Manpower costs durtog demonstration

2.2 Design cost

2.3 Inspection cost

2.4 Project managemeo

2.5 Consurustion $\cos$

2.5 .1
2.5 .2
2.5 .3

Sublow of 25

2.6 Construction managemest costs

2.7 Mans gement Reserve

2.8 Contingery

Sublotal 2.0

3.0 Troduction feciling cosstruction conts

3.1 Design cost

cionst

3.3 Project managemeot

3.4 Construction cos

3.4 .1

3.4 .2

Subwal of 3.4

3.5 Construction managemen

3.6 Masagement Reserve

3.7 Contingency

Sublotal 3.0

Giarntiona Bodget Puaded Activitien (Sen Sact 7$)$

4.1 Conceprual design

4.2 Safety nasurance

43 NEPA permining ( $\$ 6$ Mill for EIS. $\$ 1$ Mill for EA)

4.4 Preparation for operations

4.5 Project Masagemeal

(20)

Subcow 4.0

$30 \%$ of 2.5 )

( $7 \%$ of 2.5 )

( $10 \%$ of 2.5 )

Building strueture cosss

Equipmeat costs

Indirea

( $29 \%$ of $25.1 * 2.5 .2)$

( $17.1 \% 0(2.5)$

$(10 \%$ of 2.5$)$

( $25 \%$ of 2.1 through 2.7 )

Tow hitial Cont $(1.02 .0,3.0 * 4.0)$

Building struenure coss

Equipment coses

$\{\quad 25 \%$ of 3.4$)$

$10 \%$ of 3.4 )

Iodirea:

$(29 \%$ of $3.4 .1 * 3.4 .2)$

( $17.1 \%$ of 3.4$)$

$10 \%$ of 3.4$)$

(25\% or 3.1 turough 3.5)

$(1.5 \%$ o( 3.0$)$

(1\%०(3.0)

( $100 \%$ of 5.0 )

( $10 \%$ of 4.1 through 4.4)

$\begin{array}{lll}\text { so } & \text { so } & \text { so } \\ \text { so } & \text { so } & \text { so } \\ \text { so } & \text { so } & \text { so } \\ \text { so } & \text { so } & \text { so } \\ \text { so } & \text { so } & \text { so } \\ \text { so } & \text { so } & \text { so }\end{array}$

Operting and main trinenco cont:

S.1 Anulal opera eng cosis

5.2 Anoual utility costu

5.3 Annual material costs

5.4 Annual maintainence cost

S.S Contingeocy

Sublotal 5.0 year $O$ \& $M$ cost ( 20 times Sublow 5.0 )

6.0 Decontamination Decoumissioning

( 25\% of 5.1 through 5.4)

ROM Lifo cjde costs (20 pears oporation)

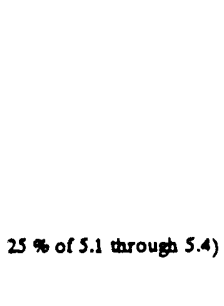

$\begin{array}{lll}\text { so } & \text { so } & \text { so } \\ \text { so } & \text { so } & \text { so } \\ \text { so } & \text { so } & \text { so } \\ \text { so } & \text { so } & \text { so }\end{array}$

so so so so




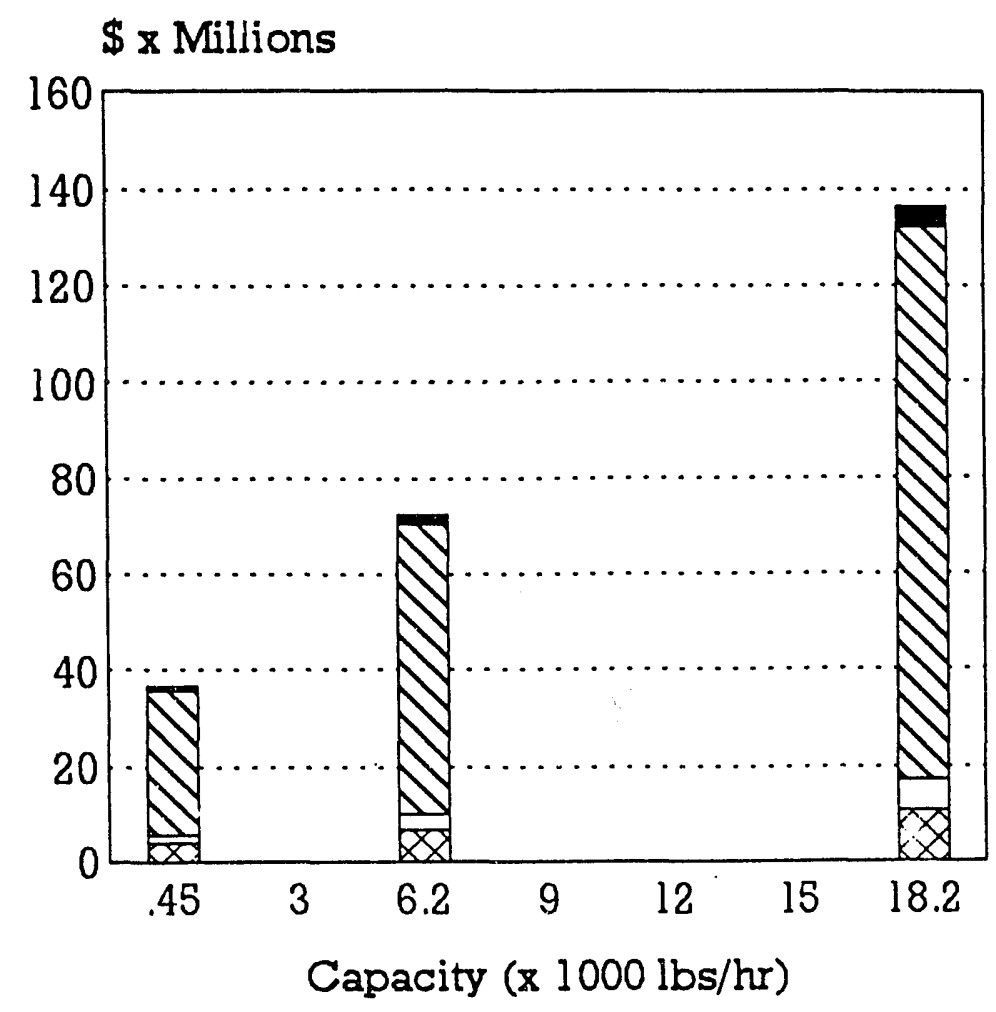

Decontam \& Decomm. D20 Yrs $O \&$ M Costs $\square$ Oper. Bud. Funded Aot. Broduation Fao. Const.

Figure 11-1. Cost versus capacity histogram for LLW/LLMW shredding and compaction facility (cost module JL).

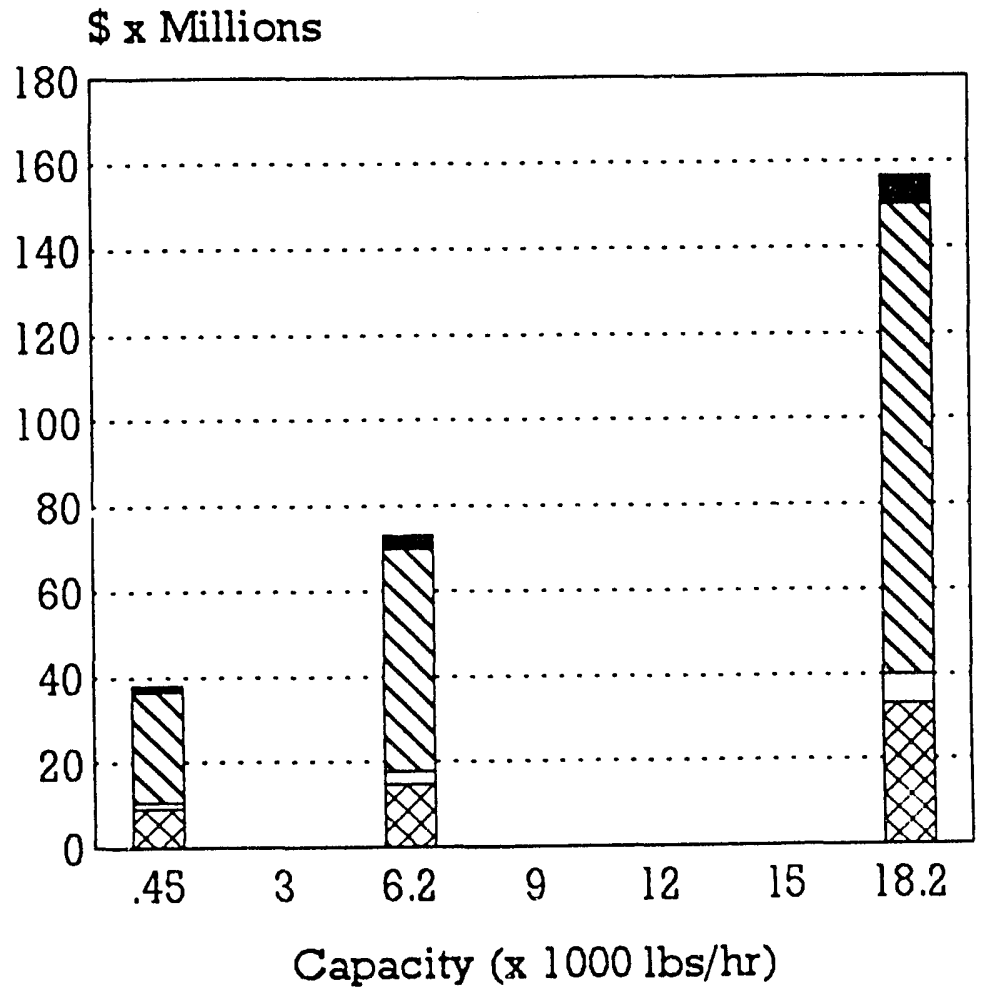

Deoontam \& Decomm $\nabla_{20}$ Yrs O \& M Costs $\square$ Oper. Bud. Funded R̆ot. $\bigotimes$ Production Fao. Const.

Figure 11-2. Cost versus capacity histogram for alpha-LLW/LLMW shredding and compaction facility (cost module JA). 


\section{STORAGE FRONT-END/BACK-END SUPPORT FACILITY (COST MODULE K)}

\subsection{Basic Information}

The storage front-end/back-end support facility is used in conjunction with the storage facilities (cost modules $\mathrm{L}, \mathrm{M}$, and $\mathrm{N}$ ) and supply all the necessary accommodations for storing LLW, LLMW, alpha-LLW/LLMW, and TRUW. The facilities combine receiving/inspection operations with administration, laboratory functions, and shipping/unloading capabilities similar to those outlined in Sections 3, 2, and 10, respectively. Unit operations are given in Figure 12-1.

\subsection{Technical Bases and Requirements}

\subsubsection{Functional and Operational Description}

Containers arrive on a transport vehicle and are unloaded using a forklift or overhead bridge crane, and placed in a staging area. The containers are visually examined, labeled, logged, recorded, and sent to inspection and assay. At the inspection/assay operation, the category of the received waste is verified against the results obtained from the back-end treatment facility. After inspection, the containers are moved to a storage area (refer to Section 13). The front-end/back-end facility is also used for shipping and loading containers that are ready for transport to disposal facilities.

The technical bases and requirements for storage front-end/back-end support facilities are the same as outlined in Sections 2, 3, 10, and Appendix A, except that the assay/inspection and certification functions are for verification purposes only. In addition, the storage front-end/back-end support facility is equipped with a computer inventory system that tracks the incoming and outgoing waste, as well as types of sampling and analysis that may be performed at the staging area (nondestructive) or the laboratory. Secondary waste generated from sampling activities is treated and packaged.

\subsubsection{Facility Integration}

Facility input includes vehicles that carry waste from the treatment facility or forklift trucks that carry waste containers from storage areas (cost modules, L, M, and $N$ in Section 13). Facility output includes containerized LLW, alpha-LLW/LLMW, TRUW, or LLMW, which is transferred to the storage bays or loaded onto trucks in containers for transport to disposal sites.

\subsection{Cost Bases, Assumptions, and Assessments}

General cost bases and assumptions are given in Appendix A. Facility specific items are discussed below. 


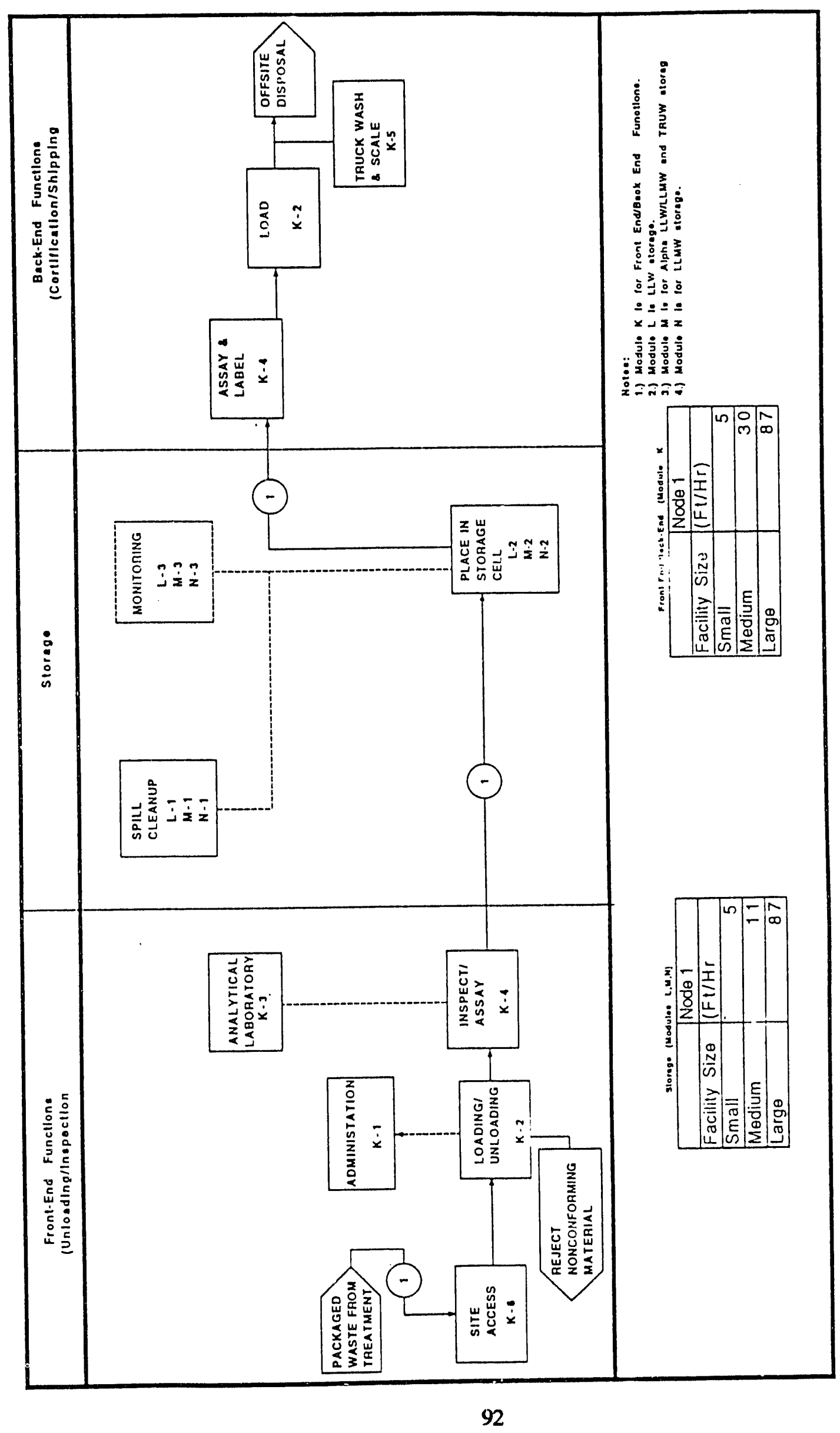

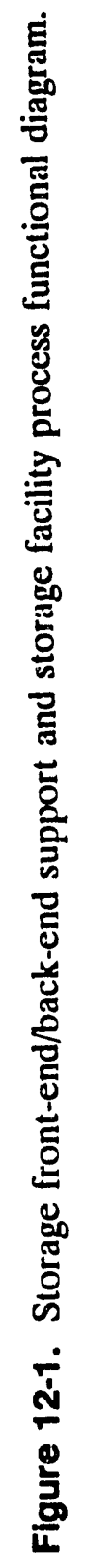


- Estimated operating staff are shown in Table 12-1. Staffing levels were estimated based on the number of personnel required to support approximately 10 separate support functions as identified in Appendix A. Storage front-end/back-end supoort staffing levels were also compared to disposal front-end facilities based on data obtained for the Illinois LLW Disposal Facility. ${ }^{7}$

- Major equipment capital cost items for this facility are the laboratory analytical equipment and overhead bridge crane.

- An allowance is made for the analytical instruments and components needed for a mixed waste laboratory. Mixed waste laboratory vendors have been consulted to ensure that the laboratory allowance is adequate. The crane cost is estimated based on vendor quotes.

- Small, medium, and large facility capacities and unit costs are shown in Table 12-2.

Table 12-1. Estimated operating staff for storage support facilities (cost module K).

\begin{tabular}{clccc}
\hline $\begin{array}{c}\text { Unit } \\
\text { operation }\end{array}$ & \multicolumn{1}{c}{ Description } & $\begin{array}{c}\text { Small } \\
\text { (FTE) }\end{array}$ & $\begin{array}{c}\text { Medium } \\
\text { (FTE) }\end{array}$ & $\begin{array}{c}\text { Large } \\
\text { (FTE) }\end{array}$ \\
\hline K-1 & Administration & 11 & 23 & 38 \\
K-2 & Loading and unloading & 4 & 16 & 32 \\
K-3 & Testing laboratory & 4 & 12 & 24 \\
K-4 & Inspect and assay & 2 & 6 & 12 \\
K-5 & Truck inspection and & 1 & 2 & 4 \\
& washout & & & \\
K-6 & Site access & 1 & 2 & 4 \\
& Total & 23 & 61 & 114 \\
\hline
\end{tabular}

Table 12-2. Capacities and unit cost information for storage front-end and/back-end facility (cost module K).

\begin{tabular}{|c|c|c|c|c|c|c|c|c|}
\hline Module & Module & Facility & Life Cycle Cost & Capacity & Unit Cost & Capacity & Cap(Tot Vol) & Unit Cost \\
\hline & Description & & $(\$ \times 1000)$ & $(\mathrm{lbs} / \mathrm{hr})$ & $(\$ / 1 b)$ & $(f t 3 / h r)$ & $(f t 3 \times 1000)$ & $(\$ / f t 3)$ \\
\hline & & & & & & & & \\
\hline $\mathrm{K}$ & Storage support & Small & .073 & 560 & $\$ 3.43$ & 5 & 403 & $\$ 384.61$ \\
\hline K & Storage support & Medium & $\$ 319,997$ & 3360 & $\$ 1.18$ & 30 & 2,419 & $\$ 132.27$ \\
\hline $\mathrm{K}$ & Storage support & Large & $\$ 611,128$ & 9744 & $\$ 0.78$ & 87 & 7,016 & $\$ 87.11$ \\
\hline
\end{tabular}

a. Average density used is $112 \mathrm{lbs} / \mathrm{ft}^{3}$. 


\subsection{Cost Summaries}

Cost summaries for the storage front-end/back-end support cost module are shown in Table 12-3. A histogram of the cost data is shown in Figure 12-2.

Staffing levels reflect waste input (unload and inspection) and waste output (certitication/shipping) throughput requirements. For a large facility, staffing levels could support, as an example, 20 drums/hour input in addition to 20 drums/hour as output. 
Table 12-3. PLCC estimate summary for storage front-end/back-end support facility (cost module $\mathrm{K}$ ).

Cost

component

Cost Items

Cost

\begin{tabular}{cc} 
Cost \\
\hline Small & $\begin{array}{c}(\$ \times 1000) \\
\text { Mediam }\end{array}$ Large \\
\hline
\end{tabular}

1.0

Strudies and beoch seale test conts

1.1 Manpower costs during research

1.2 Equipmericosts

1) Installation costs

1.4 Project manafement before title I

1.5 Contingency

$10 \%$ of 1.1 through $(.3)$

Subrotal 1.0

$25 \%$ of 1.1 throug (1.4)

Demonstrition conte

2.1 Maopower cosls during demonstration

2.2 Design cost

2.3 Inspection cost

2.4 Project managemeot

2.5 Construction cost

2.5.1 Building strueture costs

Equipment costs

Indirect

$29 \%$ of $25.1 * 25.2)$

Subrotal of 2.5

2.6 Construction management costs

2.7 Mnnagemenl Rexerve

2.8 Contingeacy

Subional 2.0

( $17.1 \%$ of 2.5 )

$10 \%$ o( 2.5$)$

( $25 \%$ of 2.1 through 2.7)

Prodection fecility construction conts

3.1 Design cost

33 Project manarement

3.4 Construction cost

$30 \%$ of 2.5 )

$7 \%$ of 2.5 )

$\begin{array}{lll}\text { so } & \text { so } & \text { so } \\ \text { so } & \text { so } & \text { so } \\ \text { so } & \text { so } & \text { so } \\ \text { so } & \text { so } & \text { so } \\ \text { so } & \text { so } & \text { so } \\ \text { so } & \text { so } & \text { so }\end{array}$

3.4 .1
3.4 .2

3.4 .2

Subrotal of 3.4

3.5 Consuruction management

3.6 Managemeat Reserve

3.7 Contingency

Sublotal 3.0

4.0

Operational Bed fet Pended Activition (Soo Sect T)

4.1 Conceprual desigo

4.2 Safery assurance

4.3 NEPA permitting ( $56 \mathrm{MOll}$ for EIS, $\$ 1 \mathrm{Mall}$ for EA)

4.4 Preparation for operations

45 Project Masagement

Subioal 4.0

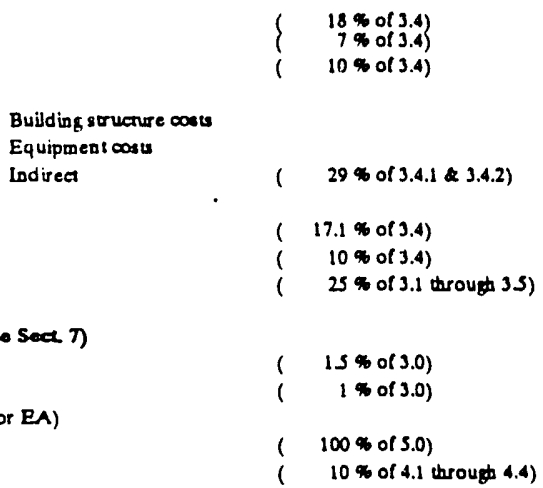

Total Initiv Cost $(1.0 .250,3.0 \times 4.0)$

5.0

Operating and main thinescos costs

5.1 Annual opera tuog costs

5.2 Annual urility costs

S3 Annual malerial costu

S.4 Anpual maintainerce conts

S.S Contingeocy

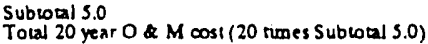

$10 \%$ of 4.1 through 4.4)

$\begin{array}{lll}s 0 & \text { so } & \text { so } \\ \text { so } & \text { so } & \text { so } \\ \text { so } & \text { so } & \text { so } \\ \text { so } & \text { so } & \text { so } \\ \text { so } & \text { so } & \text { so } \\ \text { so } & \text { so } & \text { so } \\ \text { so } & \text { so } & \text { so } \\ \text { so } & \text { so } & \text { so } \\ \text { so } & \text { so } & \text { so } \\ \text { so } & \text { so } & \text { so } \\ \text { so } & \text { so } & \text { so } \\ \text { so } & \text { so } & \text { so }\end{array}$

( $25 \%$ of 5.1 through 5.4)

6.0

Decontamination \& Decommissiouing

$\begin{array}{lll}\$ 2.207 & \$ 3.078 & \$ 5.705 \\ \$ 858 & \$ 1.197 & \$ 2.217\end{array}$

$\$ 1.226 \quad \$ 1.710 \quad \$ 3.169$

$\$ 2.534 \quad \$ 4.496 \quad \$ 9.862$

$\$ 6.972 \quad \$ 8.758 \quad \$ 14.706$

$\$ 2.757 \quad \$ 3,844 \quad \$ 7,125$

$\$ 12263 \quad \$ 17,098 \quad \$ 31.693$

$\$ 2.097 \quad \$ 2.924 \quad \$ 5.420$

$\begin{array}{lll}\$ 1.226 & \$ 1.710 & \$ 3,160\end{array}$

$\begin{array}{lll}\$ 4,663 & \$ 6.502 & \$ 12.052\end{array}$

$\begin{array}{lll}\$ 24,540 & \$ 34.219 & \$ 63,427\end{array}$

$\$ 368 \quad \$ 513 \quad 5951$

$\$ 245 \quad 5342 \quad 5634$

$\$ 5.919 \quad \$ 13.075 \quad \$ 24.995$

$\$ 653 \quad \$ 1.393 \quad \$ 2.658$

$\begin{array}{lll}\$ 7.185 & \$ 15.323 & \$ 29.238\end{array}$

$\begin{array}{lll}\$ 31.725 & 849,542 & \$ 92,665\end{array}$

$\$ 3.220 \quad \$ 8.540 \quad \$ 15.960$

$\$ 20 \quad \$ 39 \quad \$ 67$

$\begin{array}{rrr}\$ 129 & \$ 140 & \$ 1.037 \\ \$ 1.366 & \$ 1.741 & \$ 2.932\end{array}$

$\begin{array}{lll}\$ 1.184 & \$ 2.615 & \$ 4.999\end{array}$

$\$ 5.919 \quad \$ 13.075 \quad \$ 24.995$

$\begin{array}{lll}\$ 155,075 & \$ 319,997 & \$ 611,128\end{array}$ 


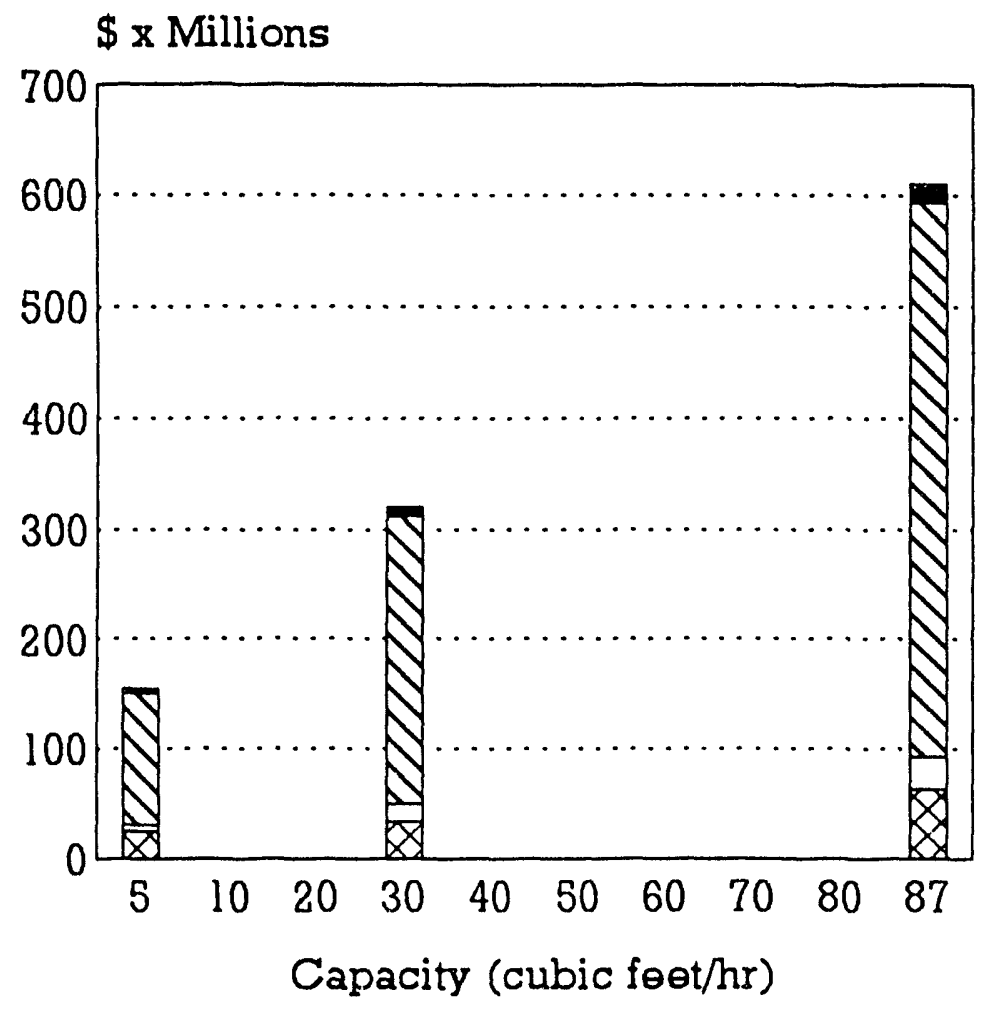

Deoontam \& Deoomm $\nabla_{20}$ Yrs O \& M Costs $\square$ oper. Bud. Funded Aot. Bproduotion Fao. Const.

Figure 12-2. Cost versus capacity histogram for storage front-end/back-end support facilities (cost module $\mathrm{K}$ ). 


\section{LLW/LLMW, ALPHA-LLW/LLMW, AND TRUW STORAGE FACILITY (COST MODULES L, M, N)}

\subsection{Basic Information}

Cost module $\mathrm{L}$ is for LLW storage, $\mathrm{M}$ is for alpha-LLW/LLMW and TRUW storage, and $\mathrm{N}$ is for LLMW storage. At a PLCC level estimate, there is no significant difference in the cost of the three types of facilities. Therefore, only one PLCC estimate is generated for the three types of facilities. Er.ch facility should be used in conjunction with the storage front-end/back-end support facility (see cost module $\mathrm{K}$ ) or as an addition to an existing facility where similar functions are already available. Unit operations are given in Figure 12-1.

The facility consists of three unit operations. Waste that arrives from the assay/inspection is stored at a specified location. The facility is equipped with a cleanup unit operation for responding to potential spills. The facility also has permanent monitoring capabilities to ensure the integrity of the stored waste containers.

\subsection{Technical Bases and Assumptions}

\subsubsection{Functiona! and Operational Description}

The storage areas include features such as spill collection and a combination of sloping floors and sumps that achieve compliance with the storage requirements of the Resource Conservation and Recovery Act (RCRA). Designated storage areas are separated by 6 -in. high (minimum) concrete berms that extend the length of the storage bays. In bays located along the outside walls, floors slope to the rear of the facility. Floors in the remainder of the bays are sloped to the center. Area monitors are included for both gamma and alpha radiation control.

\subsubsection{Facilities Iniegration}

Facility interfaces include packaged waste to and from the staging and/or assay/inspection area at the storage front-end/back-end support facility (cost module K).

\subsection{Cost Bases, Assumptions, and Assessments}

General cost bases and assumptions are given in Appendix A. Facility specific items are discussed below.

- The storage capacity has been sized to handle up to 20 years worth of waste input from treatment facilities prior to any waste being released for disposal.

- This cosı module includes no major equipment capital cost items.

- Estimated operating staff are shown in Table 13-1. 
Table 13-1. Estimated operating staff for storage areas (modules $\mathrm{L}, \mathrm{M}$, and $\mathrm{N}$ ).

\begin{tabular}{clccc}
\hline $\begin{array}{c}\text { Unit } \\
\text { operation }\end{array}$ & \multicolumn{1}{c}{ Description } & $\begin{array}{c}\text { Small } \\
\text { (FTE) }\end{array}$ & $\begin{array}{c}\text { Medium } \\
\text { (FTE) }\end{array}$ & $\begin{array}{c}\text { Large } \\
\text { (FTE) }\end{array}$ \\
\hline LMN-1 & Spill clean-up & 0 & 0 & 0 \\
LMN-2 & Place in storage & 2 & 5 & 10 \\
LMN-3 & Monitoring & $\underline{2}$ & $\underline{2}$ & $\underline{3}$ \\
& Total & 4 & 7 & 13 \\
\hline
\end{tabular}

- The storage building is the only major (cost) element, which in turn, is dependent upon the size of the facility. Accordingly, a preconceptual design of the storage building with concrete walls and concrete roof was developed for each storage facility size (small, medium, and large). These designs were used to generate an estimate.

- Small, medium, and large facility capacities and unit costs are shown in Table 13-2.

Table 13-2. Capacities and cost information for storage facility (cost module $\mathrm{L}, \mathrm{M}$, and N).

\begin{tabular}{|c|c|c|c|c|c|c|c|c|}
\hline Module & Module & Facility & Life Cycle Cos & Capacity & Unit Cost & Capacity & Cap(Tot Vol) & Unit Cost \\
\hline & Description & & $(\$ \times 1000)$ & $(\mid \mathrm{bs} / \mathrm{hr})$ & $(\$ / / b)$ & $(\mathrm{ft} 3 / \mathrm{hr})$ & $(f t 3 \times 1000)$ & $(\$ / f t 3)$ \\
\hline & & & & & & & & \\
\hline$M . N$ & ge & Small & $\overline{6}$ & 560 & $\$ 1.15$ & 5 & 403 & $\$ 128.6$ \\
\hline L.M.N & Storage & Medium & 47 & 1232 & $\$ 1.01$ & 11 & 887 & $\$ 112.56$ \\
\hline L,M.N & Storage & Large & $\$ 405,883$ & 9744 & $\$ 0.52$ & 87 & 7,016 & $\$ 57.85$ \\
\hline
\end{tabular}

a. Average density used is $112 \mathrm{lbs} / \mathrm{ft}^{3}$.

\subsection{Cost Summaries}

Cost summaries for the LLW/LLMW, alpha-LLW/LLMW, and TRUW storage cost modules are shown in Table 13-3. A histogram of the costs is shown in Figure 13-1. 
Table 13-3. PLCC estimate summary for LLW/LLMW, alpha-LLW/LLMW, and TRUW facility (cost modules $\mathrm{L}, \mathrm{M}$, and $\mathrm{N}$ ).

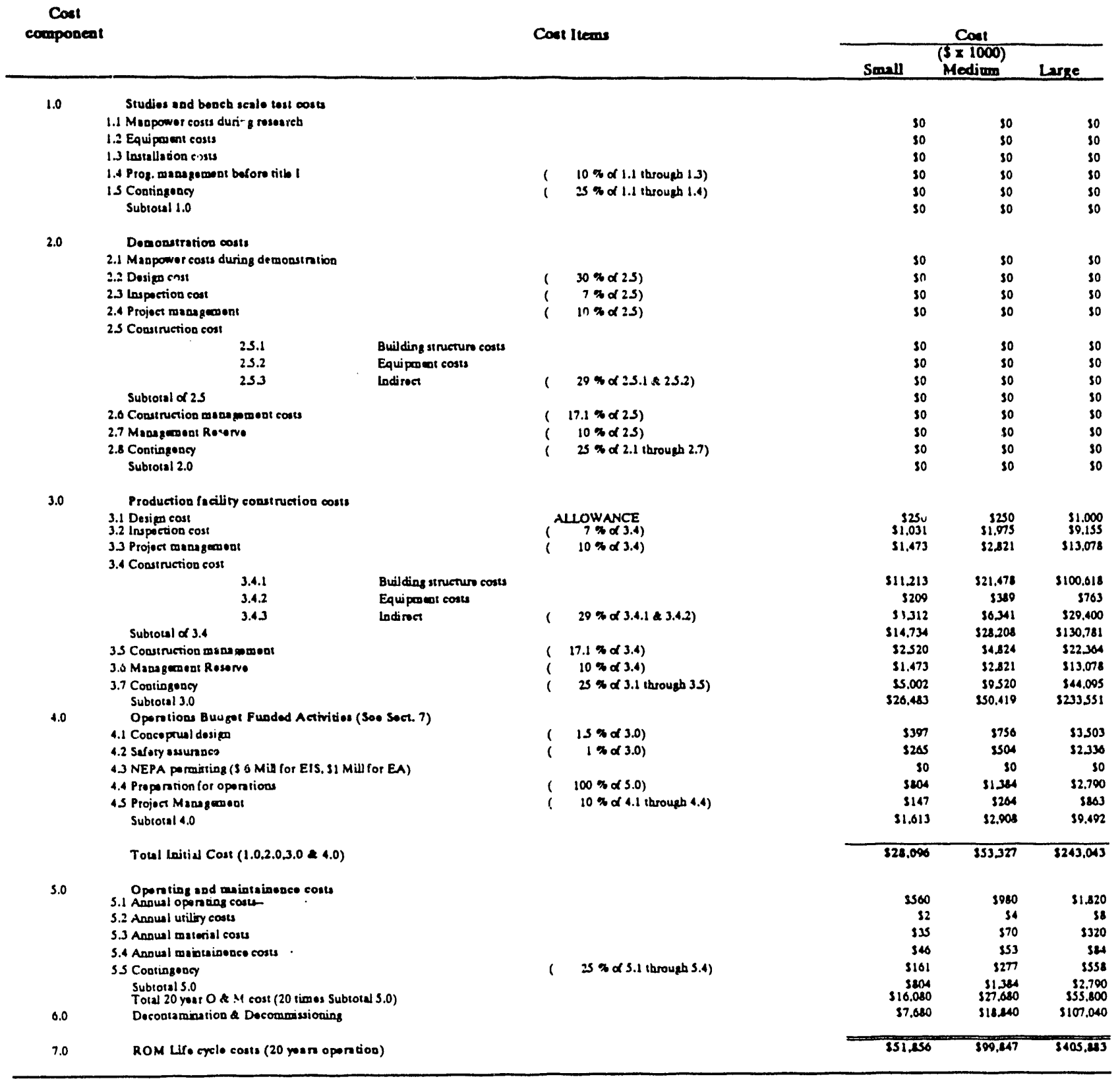




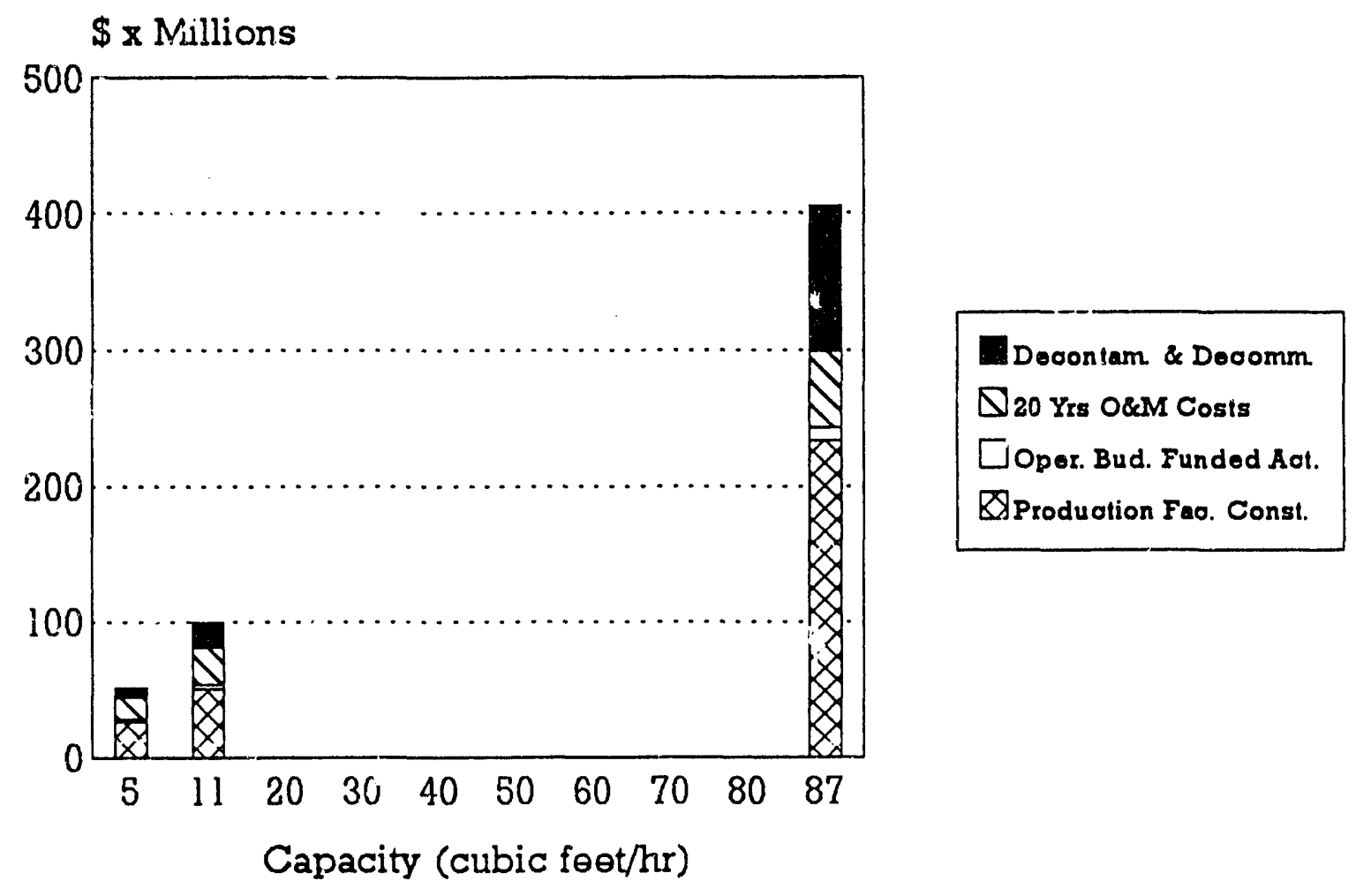

Figure 13-1. Cost versus capacity histogram for LLW, LLMW, alpha-LLW/LLMW, and TRUW storage facilities (cost modules L, M, and $N$ ). 


\section{DISPOSAL FRONT-END SUPPORT FACILITY (COST MODULE O)}

\subsection{Basic Information}

The disposal front-end support facility is used in conjunction with the disposal facilities (cost modules $\mathrm{P}$ and $\mathrm{Q}$ ) and provides all the necessary common functions for disposal of alphaLLW/LLMW and LLW/LLMW. The disposal front-end support facility unit operations include truck loading/unloading areas, administrative offices, analytical lahoratory facilities, and truck inspection and washdowns. Unit operations are given in Figure 14-1. In addition to small, medium, and large size facility, a minimum size disposal facility is estimated. The minimum size capacity is provided as a lower bound for the smallest economical engineering designed facility.

\subsection{Technical Bases and Assumptions}

\subsubsection{Functional and Operational Description}

All containers that arrive at the disposal front-end support facility are assumed to be 55-gal drums. The drums arrive in a transport vehicle, are unloaded using a forklift or overhead bridge crane, and placed in a staging area. The containers are visually examined, labeled, logged, recorded, and sent to inspection and assay. At the inspection/assay unit, the category of the received waste is verified against the results obtained from the back-end treatment and/or storage facilities. After inspection, the drums are sent to the disposal facility (modules $\mathrm{P}$ or $\mathrm{Q}$ ).

The technical bases and requirements for all clisposal front-end support facilities are also the same as those outlined in Sections 2, 3, and 10, and Appendix A, except that the assay/inspection and certification functions are for verification purposes only.

\subsubsection{Facility Integration}

Facility input includes trucks containing packaged waste from either the treatment or storage facilities. O\&M consumables including personal protective equipment must be purchased. Facility output consists of drums that are transferred to the disposal facilities.

\subsection{Cost Bases, Assumptions, and Assessments}

General cost bases and assumptions are given in Appendix A. Facility-specific items are discussed below.

- Major equipment and facility cost items for this facility are based on data obtained from the Illinois LLW Disposal Facility. ${ }^{7}$

- Estimaied operating staff are shown in Table 14-1. Staffing levels were estimated based on the number of personnel required to support approximately 10 separate support functions as identified in Appendix A. Staffing levels also based on the data obtained from the Illinois LLW Disposal Facility (License Agreement, 1991). ${ }^{7}$ 


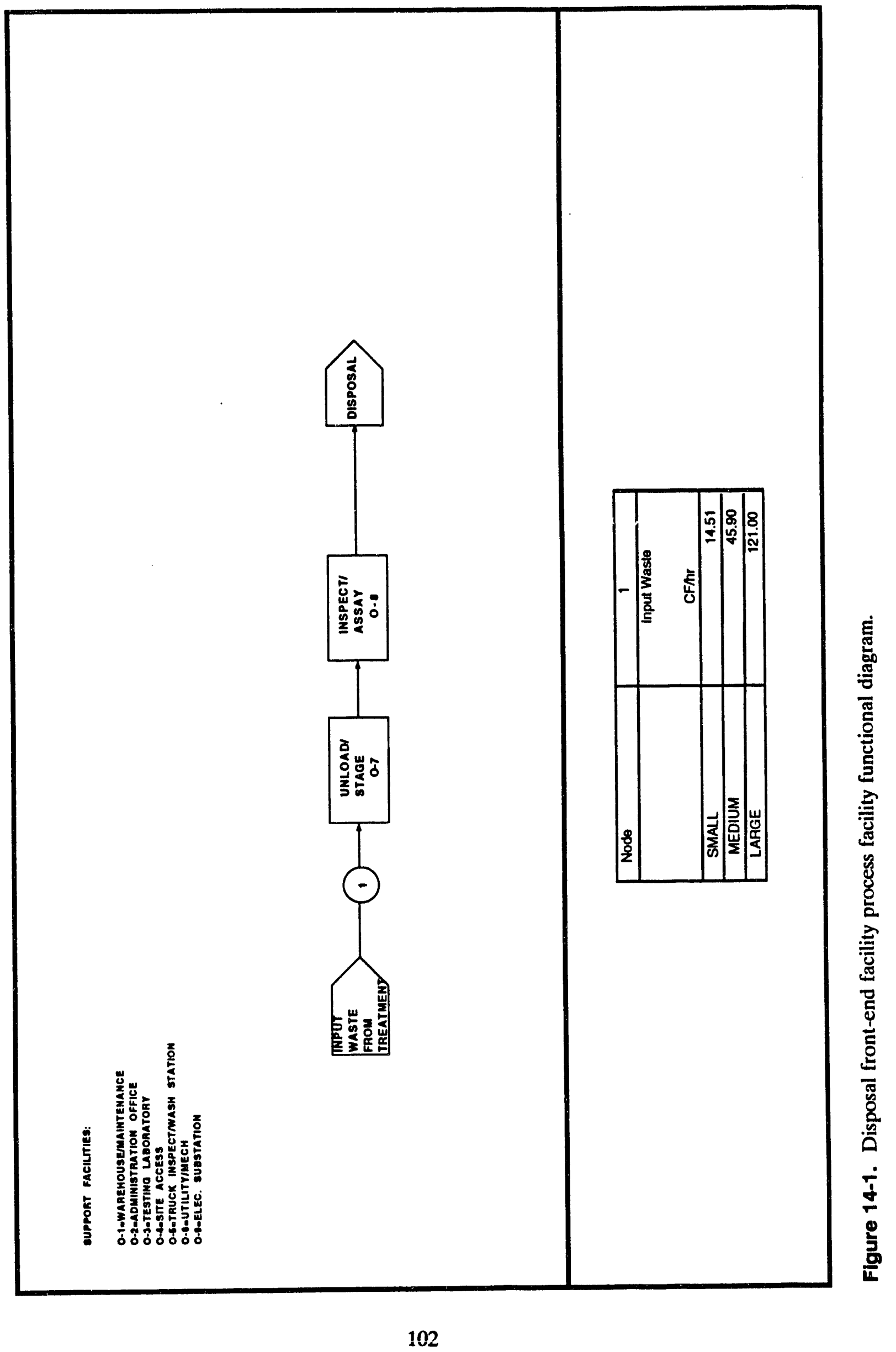


Table 14-1. Estimated operating staff for disposal front-end facility (cost module 0).

\begin{tabular}{|c|c|c|c|c|c|}
\hline $\begin{array}{c}\text { Unit } \\
\text { operation }\end{array}$ & Description & $\begin{array}{l}\text { Minimum } \\
\text { (FTE) }\end{array}$ & $\begin{array}{l}\text { Small } \\
\text { (FTE) }\end{array}$ & $\begin{array}{c}\text { Medium } \\
\text { (FTE) }\end{array}$ & $\begin{array}{l}\text { Large } \\
\text { (FTE) }\end{array}$ \\
\hline 0-1 & Warehouse and maintenance & 1 & 3 & 3 & 6 \\
\hline $0-2$ & Administration/technical & 5 & 24 & 35 & 50 \\
\hline $0-3$ & Testing laboratory & 2 & 7 & 10 & 15 \\
\hline $0-4$ & Site access & 4 & 12 & 18 & 31 \\
\hline $0-5$ & Truck inspection and washout & 2 & 6 & 6 & 12 \\
\hline $0-6$ & Unload/stage & 1 & 6 & 9 & 12 \\
\hline 0.7 & Inspect and assay & 3 & 4 & 6 & 12 \\
\hline 0.8 & Utility and mechanical & 1 & 2 & 2 & 3 \\
\hline \multirow[t]{2}{*}{$0-9$} & Electrical substation & $\underline{0}$ & $\underline{0}$ & $\underline{0}$ & $\underline{0}$ \\
\hline & Total & 19 & 64 & 89 & 141 \\
\hline
\end{tabular}

- A \$1 million allowance is made for the analytical instruments and components needed for a mixed-waste laboratory. Mixed-waste laboratory vendors have been consulted to ensure that the laboratory allowance is adequate. The crane cost is estimated based on vendor quotes.

- Minimum, small, medium, and large facility capacities and unit costs are shown in Table 14-2.

Table 14-2. Capacities and cost information for disposal front-end facility (cost module 0). ${ }^{\mathrm{a}}$

\begin{tabular}{|c|c|c|c|c|c|c|c|c|}
\hline Module & Module & Facility & Life Cycle Cost & Capacity & Unit Cost & Capacity & Cap(Tot Vol) & Unit Cost \\
\hline & Description & & $(\$ \times 1000)$ & $(\mathrm{lbs} / \mathrm{hr})$ & $(\$ / 1 b)$ & $(f+3 / h r)$ & $(\mathrm{ft} 3 \times 1000)$ & $(\$ / f t 3)$ \\
\hline & & & & & & & & \\
\hline 0 & Disposal Support & Minimum & $\$ 159,705$ & 224 & $\$ 8.84$ & 2 & 161 & $\$ 990.23$ \\
\hline 0 & Disposal Support & Small & $\$ 328,104$ & 1624 & $\$ 2.51$ & 14.5 & 1,169 & $\$ 280.60$ \\
\hline 0 & Disposal Support & Medium & $\$ 441,571$ & 5152 & $\$ 1.06$ & 46 & 3,709 & $\$ 119.04$ \\
\hline $\bar{O}$ & Disposal Support & Large & $\$ 697,007$ & 13552 & $\$ 0.64$ & 121 & 9,757 & $\$ 71.43$ \\
\hline
\end{tabular}

a. Average density used is $112 \mathrm{lbs} / \mathrm{ft}^{3}$.

\subsection{Cost Summaries}

Cost summaries for the disposal front-end support facility is shown in Table 14-3. A histogram for cost versus capacity is given in Figure 14-2. 
Table 14-3. PLCC estimate summary for disposal common support facility (cost module 0).

Cost

component

Cost Items

\begin{tabular}{cc} 
& Cost \\
\hline Minimum Small & $\begin{array}{l}(\$ \mathrm{x} 1000) \\
\text { Mediom }\end{array}$ Large \\
\hline
\end{tabular}

1.0

Studies and booch scalo tost costs

1.1 Manpowor coses during resos ret

1.2 Equiponet costs

1.3 Invtallacion costs

1.4 Project managemeat before titlel

13 Contingougy

$10 \% \times 1.1$ through 1.3

Subrotal 1.0

$25 \%$ of 1.1 through 1.4$)$

Demonstration costs

2.1 Manpower costs during decoonstntion

2.2 Dosigen cost

2.3 Inspection cost

2.4 Project managewent

2.5 Construction cost

$7 \%$ of 2.5$)$

$25.1 \quad$ Building structure cosss

25.2 Equiponest cosis

Subrotsl of 25

Indirect

( $20 \%$ or $25.1 * 25.2)$

2.6 Const ruction manapement costs

2.7 Magagument Resorve

2.8 Cootingedoy

Subtotal 2.0

$17.1 \%$ o( 25)

( $10 \%$ or 2.5 )

( $25 \% \propto 2.1$ tbrough 2.7)

Production fadity construction costs

3.1 Desige cost

gromon

$18 \%$ o 3.4

$10 \%$ of 3.4

Building structurs costs

Equiponat costs

3.4 .2

Indirect

$(\quad 29 \%$ of 3.4.1 3.4.2)

Subtotal of 3.4

35 Construction manepoment

3.6 Managueseat Resorvo

3.7 Contingency

Subroial 3.0

4.0 Opentions Budgot Punded Activities (Soe Sect. 7)

4.1 Conceprual desion

4.2 Safory assunace

4.3 NEPA pormirtiog ( 36 Min for EIS, 31 Mill for EA)

4.4 Proparntion for opentions

45 Projert Menageneat

Subtota] 4.0

Totel Lnitial Cost $(1,0,2.0,3.0<4.0)$

$(17.1 \% \propto 3.4)$

$\left\{\begin{array}{l}10 \% \times 3.4) \\ (25 \% \times 3.1 \text { through } 3.5)\end{array}\right.$

$(15 \%$ o( 3.0$)$

$(1 \% \times 3.0)$

$(100 \% \times 3.0)$

( $10 \% \propto 4.1$ through 4.4)

$5.0 \quad$ Openting end maintainesce costs

S.2 Anousl urility costs

3.3 Annual natorial costs

S.4 Annual ma intuinedce coss'.

SS Contisgency

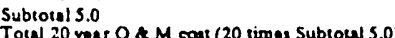

6.0

Decontaminution a Docommissioning

( $25 \% \propto$ ( 5.1 through 5.4 )

ROM Lifo cycle costs (20 poun operation)

$\begin{array}{llll}30 & 30 & 30 & 30 \\ 30 & 30 & 30 & 30 \\ 30 & 30 & 30 & 30 \\ 30 & 30 & 30 & 30 \\ 30 & 30 & 30 & 30 \\ 30 & 30 & 30 & 30\end{array}$

\begin{tabular}{|c|c|c|}
\hline 30 & 30 & so \\
\hline 30 & so & so \\
\hline so & so & so \\
\hline so & so & 30 \\
\hline so & so & so \\
\hline so & 10 & so \\
\hline so & so & so \\
\hline so & so & so \\
\hline so & so & so \\
\hline so & so & 30 \\
\hline 30 & so & so \\
\hline so & so & 30 \\
\hline
\end{tabular}

$\begin{array}{llll}\$ 3.059 & \$ 3.050 & \$ 4 \$ 67 & \$ 7.026 \\ \$ 1.423 & \$ 1.423 & \$ 1.776 & \$ 2.960\end{array}$

$\$ 2.033 \quad \$ 2.033$

$\$ 90.872 \quad \$ 9.872 \quad 311.978 \quad \$ 21.430$

$\begin{array}{llll}\$ 5.888 & \$ 5.888 & 37.089 & \$ 11.402\end{array}$

$\$ 4370 \quad \$ 4370 \quad \$ 5.703 \quad 39524$

$\$ 20.330 \quad \$ 20.330 \quad \$ 25.370 \quad 342.305$

$\$ 33.476 \quad \$ 3,476 \quad 34.338 \quad \$ 7.244$

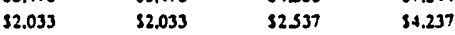

$\begin{array}{llll}\$ 7.730 & \$ 37.730 & \$ 39.647 & \$ 16.110\end{array}$

$\$ 40.684 \quad \$ 40.084 \quad \$ 50.772 \quad 384.785$

$\begin{array}{rrrr}\$ 610 & \$ 610 & \$ 762 & \$ 1.272 \\ \$ 407 & 3407 & \$ 308 & \$ 848 \\ \$ 6.000 & \$ 0.000 & \$ 0.000 & \$ 0.000 \\ \$ 5.221 & \$ 13.202 & \$ 18.066 & \$ 28.470 \\ \$ 1.224 & \$ 2.022 & \$ 2.534 & \$ 3.050 \\ \$ 13.402 & \$ 22.241 & \$ 27.870 & \$ 40.249\end{array}$

$\begin{array}{llll}\$ 54.146 & \$ 62.925 & \$ 78.642 & \$ 125.034\end{array}$

\begin{tabular}{|c|c|c|c|}
\hline$\$ 2.060$ & 38.900 & $\$ 12.460$ & $\$ 19.740$ \\
\hline s1 & 36 & $\$ 10$ & $3+0$ \\
\hline$\$ 282$ & $\$ 362$ & $\$ 362$ & 3005 \\
\hline 31.234 & 31.234 & $\$ 1.012$ & 32.382 \\
\hline 31.044 & 32.040 & $\$ 3,013$ & $\$ 3,094$ \\
\hline $\begin{array}{r}35.221 \\
\$ 104.420\end{array}$ & $\begin{array}{l}313.202 \\
3264.040\end{array}$ & $\begin{array}{r}\$ 18.000 \\
5361.320\end{array}$ & $\begin{array}{r}\$ 28.470 \\
\$ 569.400\end{array}$ \\
\hline$\$ 1,139$ & 31.139 & $\$ 1,000$ & 32.573 \\
\hline $40 \mathrm{sen}$ & $\$ 328.10$ & 3441571 & 3697,0 \\
\hline
\end{tabular}




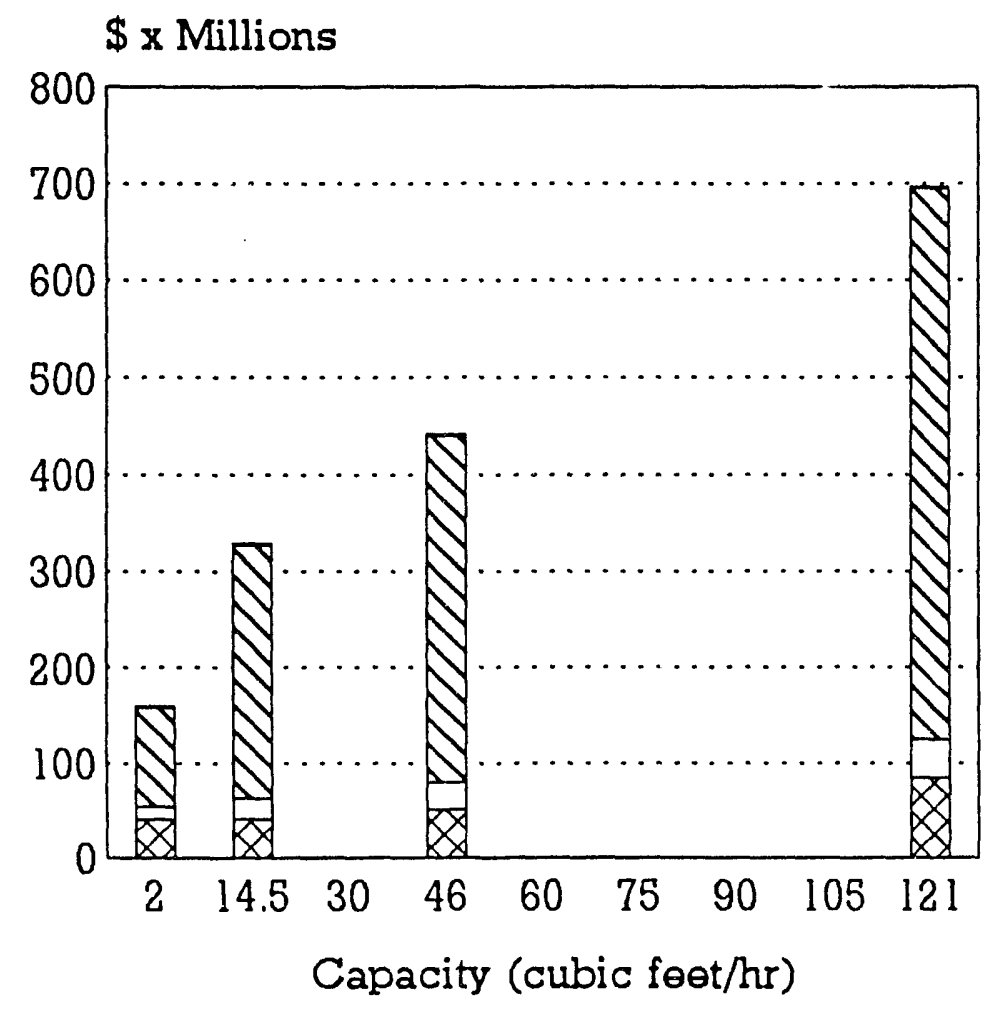

Deoontam. \& Deoomm. Si20 Irs O\&M Costs $\square$ Oper. Bud. Funded Aat. BProduction Fao. Const.

Figure 14-2. Cost versus capacity histogram for disposal front-end facility (cost module 0). 


\section{ENGINEERED DISPOSAL FACILITIES (COST MODULES P AND Q)}

\subsection{Basic Information}

The engineerud disposal facilities should be used in conjunction with the front-end support facility (see cost module $\mathrm{O}$ ) or as an addition to existing facilities where similar functions are already available. The facility consists of engineered disposal units that are based on the Illinois LLW disposal facility ${ }^{b}$ design, shown in Figure 5-1, which uses an earth mound concrete cell concept. ${ }^{7}$ Engineered disposal facilities for radioactive (non-RCRA) waste and mixed (RCRA) waste are essentially the same with the exception that a mixed waste disposal unit has a double leachate collection system in compliance with the RCRA requirements. Cost module $P$ is applicable to nonRCRA waste (LLW and alpha-LLW) while cost module $Q$ is for RCRA mixed waste (LLMW and alpha-LLMW). Unit operations for both types of facilities are given in Figure 15-2.

The unit operations include receiving the inspected drums from the front-end facility, placing the drums into concrete canisters, and constructing the disposal units that will house incoming concrete waste canisters. Disposal unit construction includes foundation and monitoring system, concrete vaults, and earth-mound covers. Construction of the facilities is intended to be a continuous process concurrent with the placement of the canisters. Both disposal facilities (cost modules $\mathrm{P}$ and $Q$ ) are designed for long-term endurance and monitoring. In addition, the mixed waste disposal facility (module $\mathrm{Q}$ ) is designed to meet RCRA standards and is equipped with a secondary lcachate collection system.

\subsection{Technical Bases and Assumptions}

\subsubsection{Functional and Operational Description}

The drums received from the disposal front-end support facility are packaged into concrete canisters that are then sealed with grout. The canisters are transported to the disposal units for placement. Each disposal unit is comprised of a double row of concrete cells with an access aisle between the two rows. Concrete canisters that arrive from the packaging area are placed in a cell via crane or forklift in the access aisle and stacked three canisters high. Once the cell is full, it is backfilled with a sandy material and sealed with concrete. A concrete cover is concurrently constructed over the sealed cells.

The cells are capped with an earth mound layer that is engineered to withstand long-term environmental and weathering effects. The layered cap consists of sandy drain layers placed directly over the cells, an impervious clay layer, a high density polyethylene (HDPE) liner, and another drain layer to deter seepage into the cells. The top layer consists of either subsoil and vegetative material or subsoil, bedding, and riprap. The monitoring system includes sensors that will detect any leakage from the cells.

b. Information obtained from Illinois Low-Level Radioactive Waste Disposal Facility, Executive Summary. 


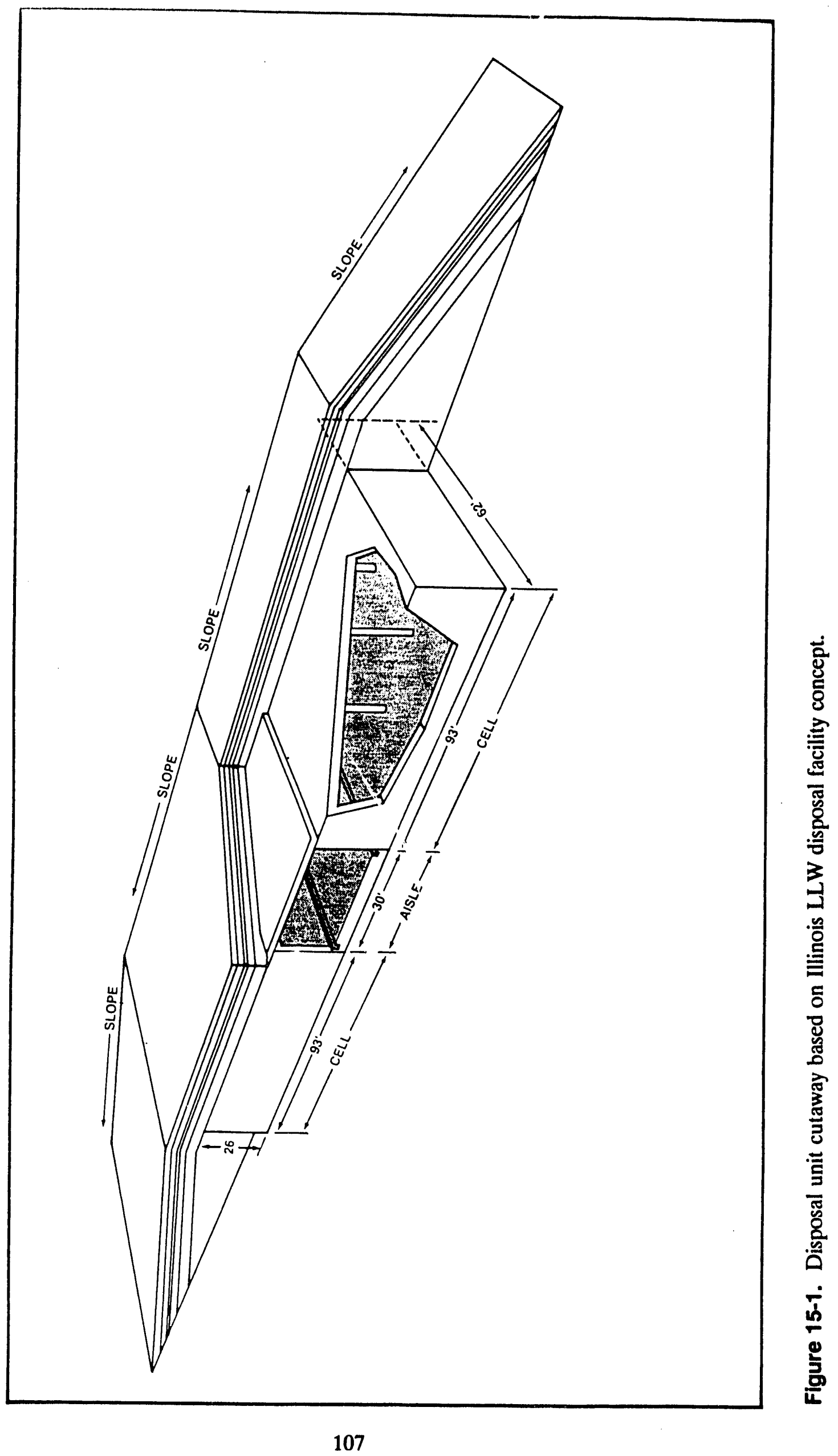




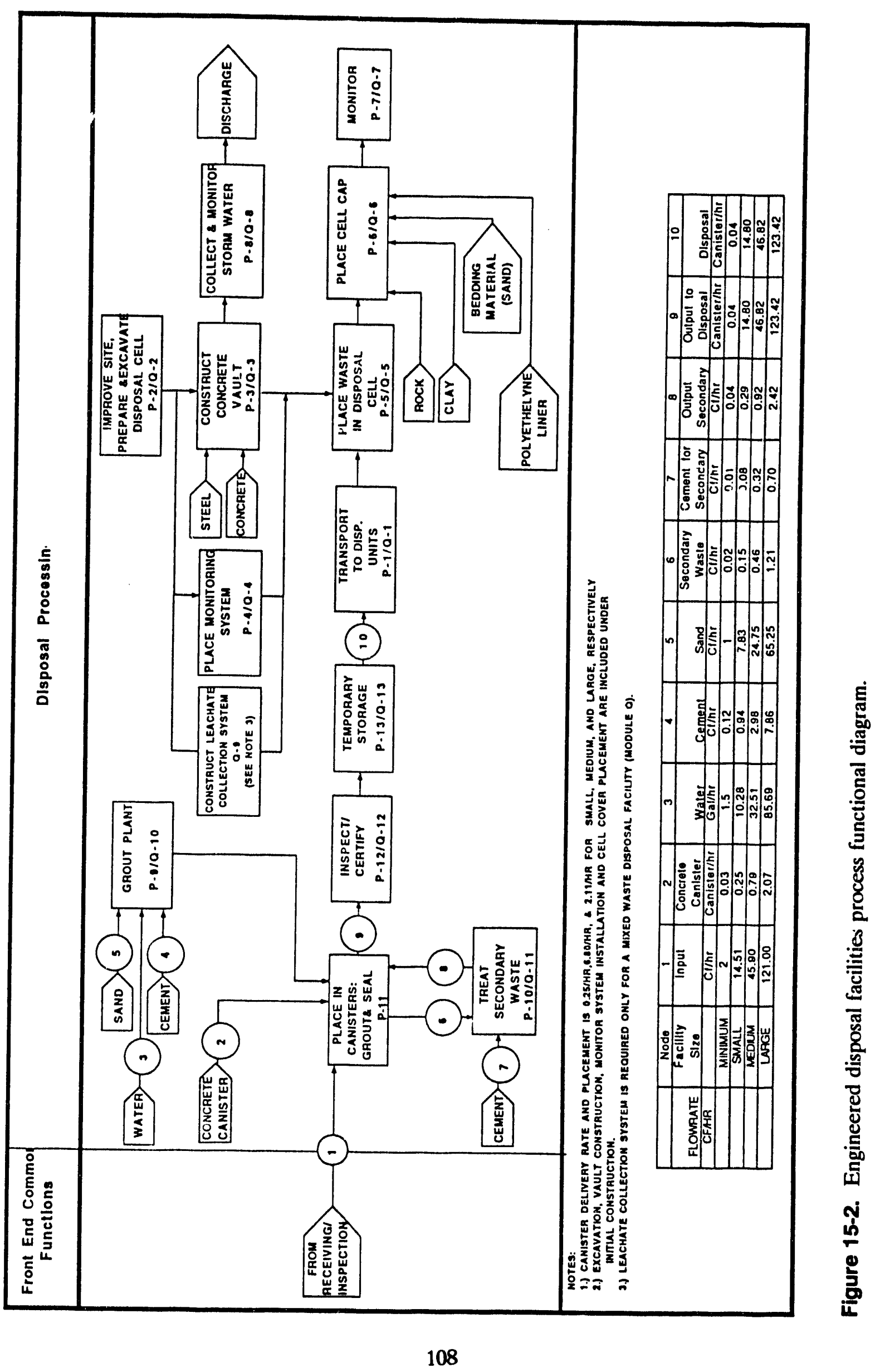


The D\&D includes facility demolition and the disposal unit maintenance. Disposal unit maintenance is planned in two stages, each with two substages: short-term maintenance comprised of closure and post-closure periods and long-term maintenance, which consists of active institutional care and passive institutional care.

Closure activities take place during the first 2 years after the facility ceases to accept waste. Closure includes decontamination of the facilities, initial demolition of buildings, site development, closure of the cells, site remediation, and monitoring of the cell performance and groundwater. Years 1 through 10 after the facility ceases to accept waste are designated as the post-closure period. During this period monitoring of the groundwater and cell performance will continue, as well as site remediation and development.

Active institutional care is planned for 11 to 100 years following the post-closure period. During this stage, any buildings not previously demolished are torn down and all site services are removed, in addition to ongoing monitoring activities from post-closure. The last stage, passive institutional care, extends from 101 to 300 years after the facility ceases to accept waste. Passive institutional care includes closure of the center aisles of the vaults, completion of the earth mound caps and site grading, removal of the retention ponds and retaining walls, and installation of passive drains. Longterm maintenance is discontinued after 300 years.

\subsubsection{Facility Integration}

Input interfaces include waste drums delivered from the front-end facility (refer to cost module O). O\&M consumables including empty concrete canisters, grout, sand, and personnel protective equipment must be purchased. The facility is intended for permanent disposal of the waste and designed for long-term maintenance and monitoring as described above. No facility output is anticipated for a lengthy time period (at least 300 years).

\subsection{Cost Bases, Assumptions, and Assessments}

General cost bases and assumptions are given in Appendix A. Facility-specific items are discussed below.

- Major equipment capital cost items are a forklift and a crane for placement of the drums into canisters and placement of filled canisters into the concrete cells. Costs for these items are based on vendor quotes.

- Estimated operating staff are shown in Table 15-1. This staffing is based on data obtained from the Illinois LLW Disposal Facility ${ }^{7}$ and a DOE conceptual design report (DOE/LLW-60T, 1987). ${ }^{8}$

- Construction of the disposal units is a major cost item. A preconceptual design of one disposal unit that applies to all facilities, including concrete cells and cover design, was developed based on the design of the Illinois LLW Disposal Facility. A unit cost per cell was developed based on data from the Illinois facility, and an estimate was generated according to the rate of incoming waste and number of cells required for each small, medium, and large facility. 
Table 15-1. Estimated operating staff for disposal facility (cost modules $P$ and $Q$ ).

\begin{tabular}{llcccc}
\hline $\begin{array}{c}\text { Unit } \\
\text { operation }\end{array}$ & \multicolumn{1}{c}{ Description } & $\begin{array}{c}\text { Minimum } \\
\text { (FTE) }\end{array}$ & $\begin{array}{c}\text { Small } \\
\text { (FTE) }\end{array}$ & $\begin{array}{c}\text { Medium } \\
\text { (FTE) }\end{array}$ & $\begin{array}{c}\text { Large } \\
\text { (FTE) }\end{array}$ \\
\hline P-1/Q-1 & Transport to disposal units & 1 & 2 & 3 & 3 \\
P-2/Q-2 & Prepare and excavate disposal cell & 0 & 0 & 0 & 0 \\
P-3/Q-3 & Construct concrete vault & 0 & 0 & 0 & 0 \\
P-4/Q-4 & Place monitoring system & 0 & 0 & 0 & 0 \\
P-5/Q-5 & Place waste in disposal cell & 2 & 9 & 9 & 18 \\
P-6/Q-6 & Place cell cap & 0 & 0 & 0 & 0 \\
P-7/Q-7 & Monitor & 1 & 2 & 2 & 4 \\
P-8/Q-8 & Collect and monitor storm water & 1 & 2 & 2 & 4 \\
Q-9 & Construct leachate collect system & 0 & 0 & 0 & 0 \\
P-9/Q-10 & Grout plant & 5 & 8 & 8 & 16 \\
P-10/Q-11 & Treat secondary waste & 1 & 2 & 3 & 4 \\
P-11/Q-12 & Place in canister-grout and seal & 4 & 15 & 15 & 30 \\
P-12/Q-13 & Inspect certify & 1 & 4 & 4 & 8 \\
P-13/Q-14 & Temporary storage & 0 & 0 & $\underline{0}$ & 0 \\
& Total & 16 & 41 & 61 & 90 \\
\hline
\end{tabular}

- Minimum small, medium, and large facility capacities and unit costs are shown in Table 15-2. Minimum size capacity is provided as a lower bound for the smallest economical engineering designed facility.

- Estimates are based on a disposal facility in accordance with NRC criteria, but a NRC license is not assumed.

Table 15-2. Capacities and cost information for engineering disposal facility (cost module $P$ and $Q$ ).

\begin{tabular}{|c|c|c|c|c|c|c|c|c|}
\hline Module & Module & Facility & Life Cycle Cost & Capacity & Unit Cost & Capacity & Cap(Tot Vol) & Cost \\
\hline & Description & & $(\$ \times 1000)$ & $(\mathrm{lbs} / \mathrm{hr})$ & $(\$ / 1 b)$ & $(f t 3 / h r)$ & $(113 \times 1000)$ & $(\$ / f+3)$ \\
\hline & & & & & & & & \\
\hline$P$ & Engr. Disposal & linimum & $\$ 327,121$ & 224 & $\$ 18.11$ & 2 & 161 & $\$ 2,028.28$ \\
\hline P & Engr. Disposal & Smail & $\$ 491.233$ & 1624 & $\$ 3.75$ & 14.5 & 1.169 & $\$ 420.1$ \\
\hline$P$ & Engr. Disposal & Medium & $\$ 886,506$ & 5152 & $\$ 2.13$ & 46 & 3,709 & $\$ 238.99$ \\
\hline $\mathrm{P}$ & Engr. Disposal & Large & $\$ 2,146,360$ & 13552 & $\$ 1.96$ & 121 & 9,757 & $\$ 219.97$ \\
\hline Q-RCRA & Engr. Disposal & Minimum & $\$ 334,328$ & 224 & $\$ 18.51$ & 2 & 161 & $\$ 2.072 .97$ \\
\hline Q-RCRA & Engr. Disposal & Small & $\$ 495,628$ & 1624 & $\$ 3.78$ & 14.5 & 1,169 & $\$ 423.87$ \\
\hline QRCRA & Engr. Disposal & Medium & $\$ 897,026$ & 5152 & $\$ 2.16$ & 46 & 3,709 & $\$ 241.82$ \\
\hline QRCRA & Engr. Disposal & Large & $\$ 2,168,827$ & 13552 & $\$ 1.98$ & 121 & 9,757 & $\$ 222.27$ \\
\hline
\end{tabular}




\subsection{Cost Summaries}

General cost summaries for the engineered disposal facilities are shown in Tables 15-3 and 15-4. Histograms for cost versus capacity are given in Figures 15-3 and 15-4.

Table 15-3. PLCC estimate summary for alpha-LLW and LLW engineered disposal facility (cost module $\mathrm{P}$ ).

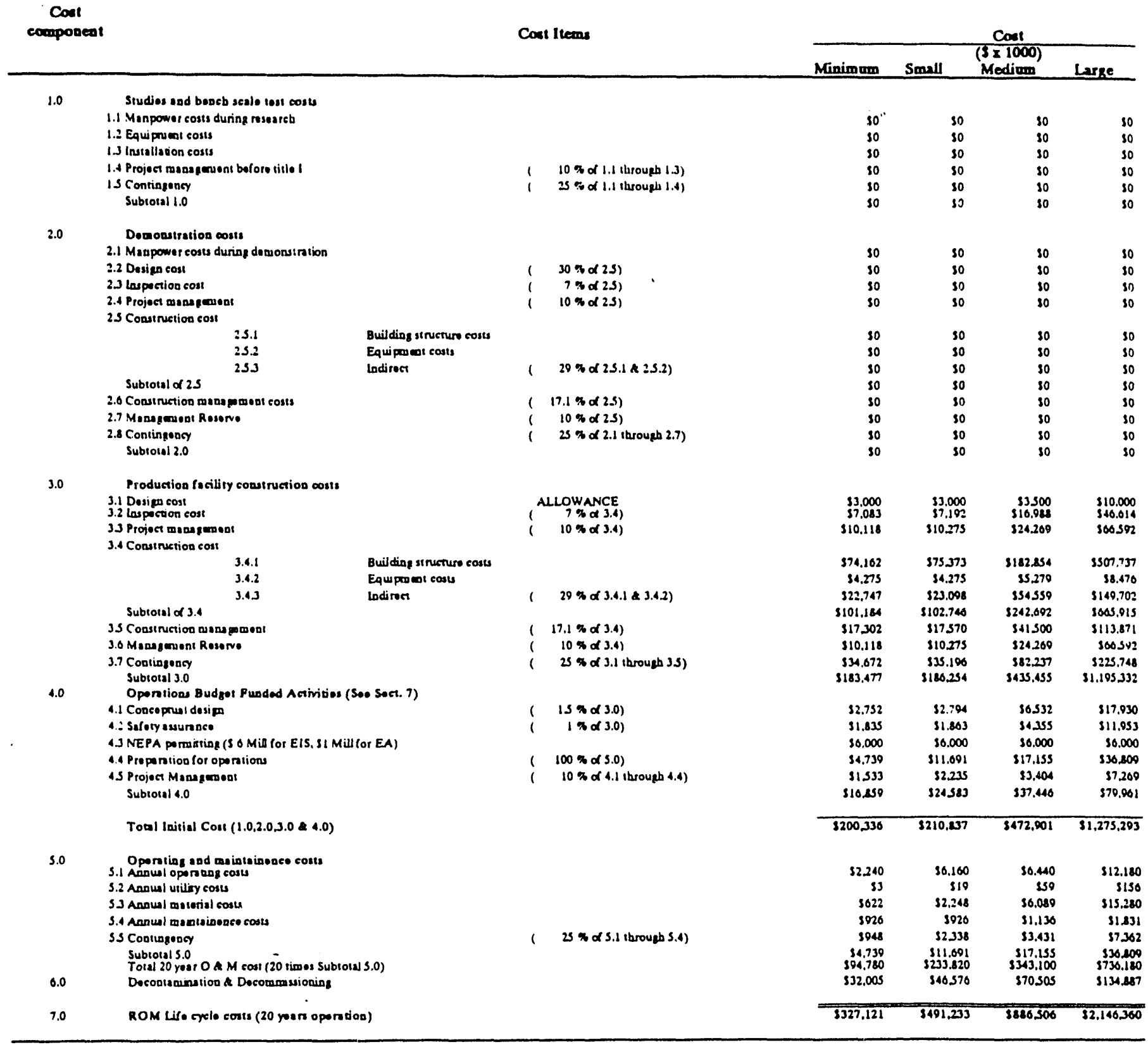


Table 15-4. PLCC estimate summary for alpha-LLMW engineered disposal facility (cost module Q).

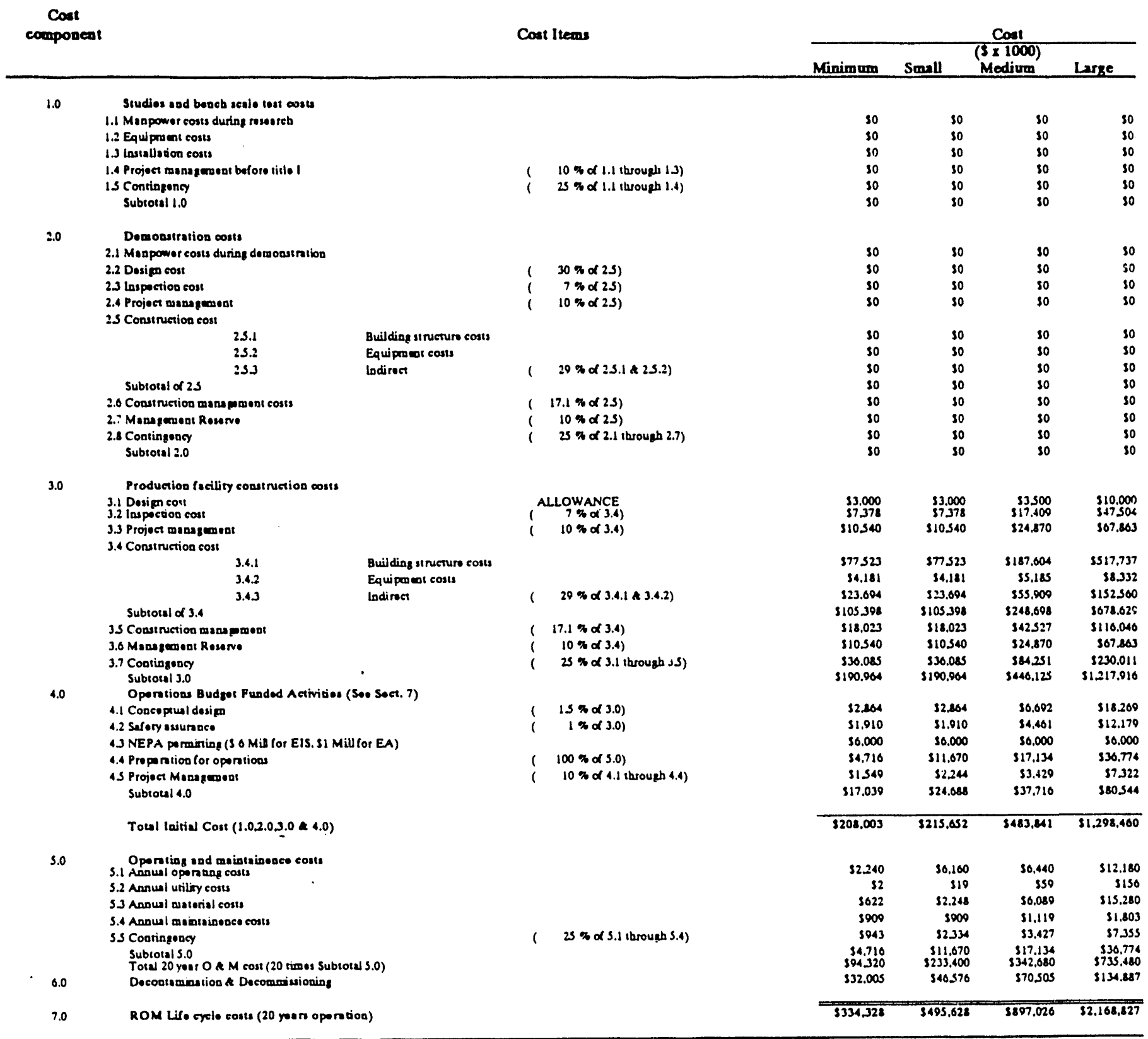




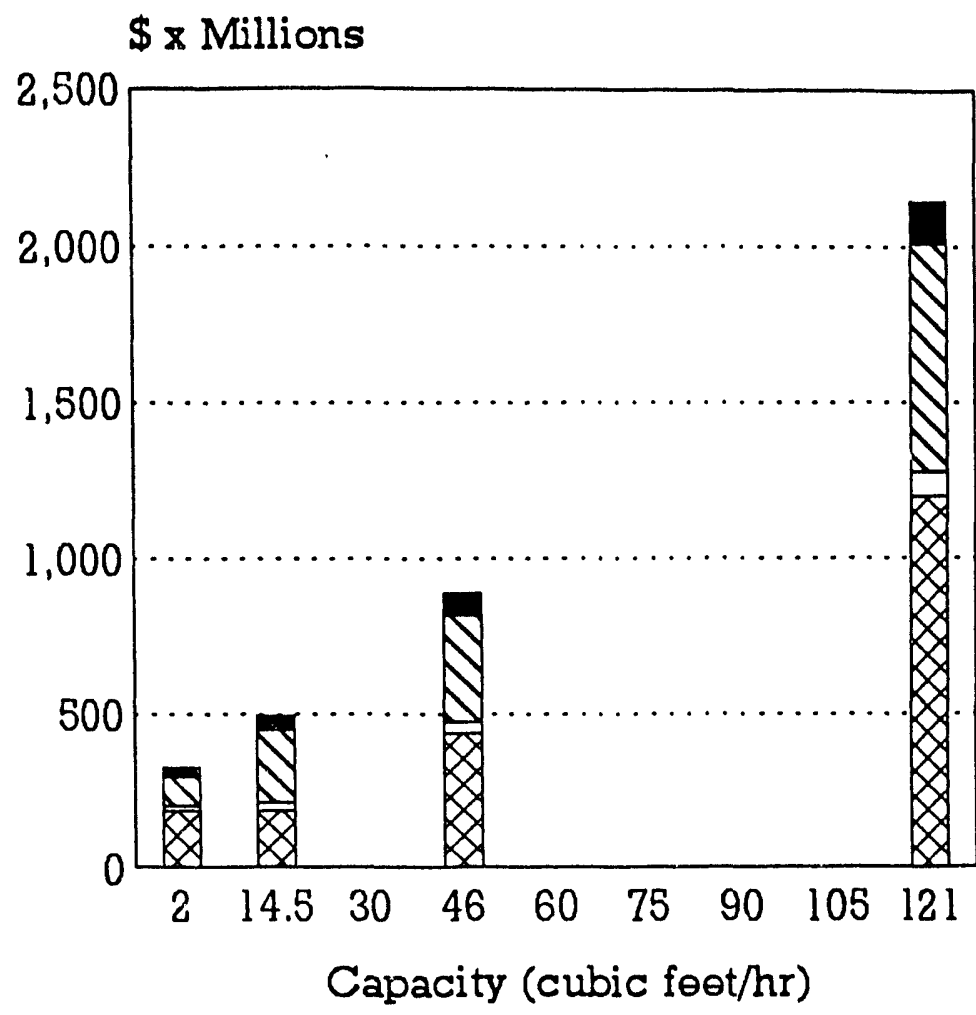

Decontam \& Deoomm Q20 Yrs O \& M Costs $\square$ Oper. Bud. Funded Aot. Production Fao. Const.

Figure 15-3. Cost versus capacity histogram for LLW and alpha-LLW engineered disposal facility (cost module P).

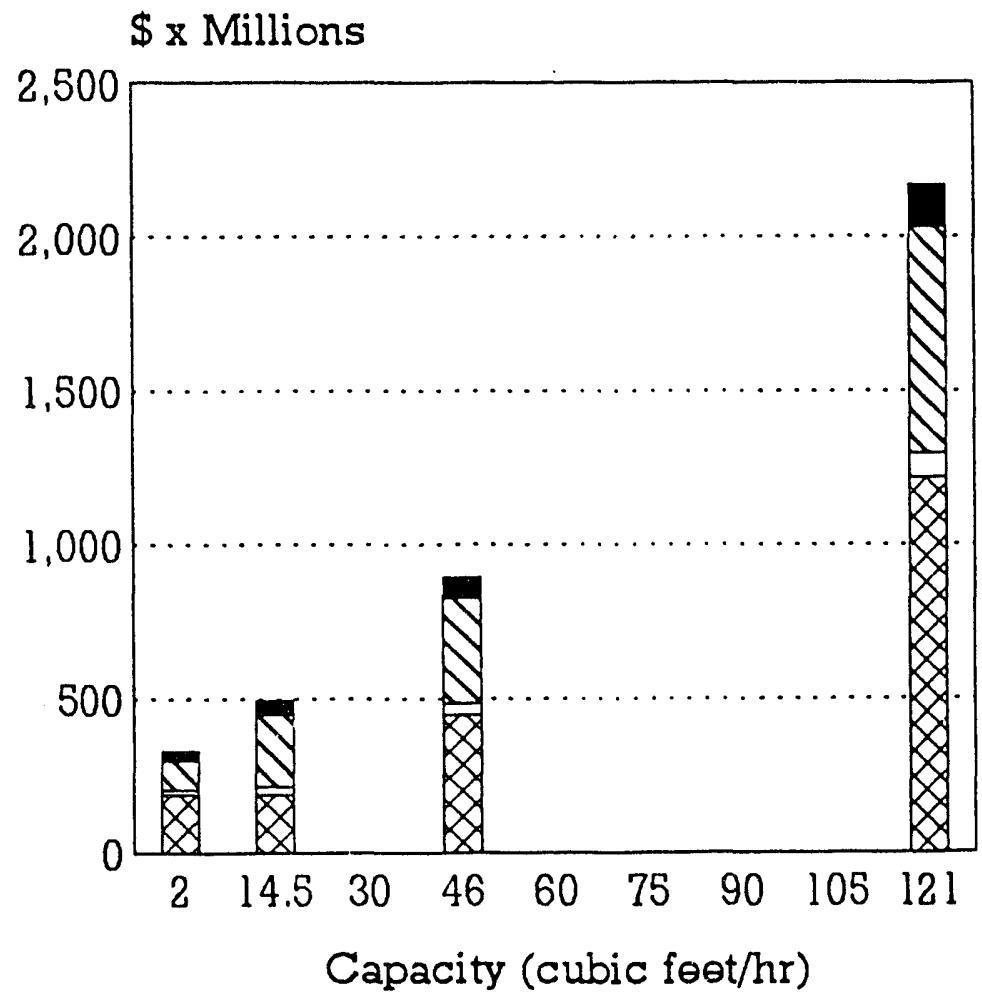

Dooontam \& Decomm $\nabla_{20}$ yrs $O \&$ Costs $\square$ Oper. Bud. Fundod Aot. $\bigotimes$ Produation Fao. Const.

Figure 15-4. Cost versus capacity histogram for LLW and alpha-LLW engineered disposal facility (cost module Q). 


\section{SHALLOW LAND DISPOSAL FACILITY (COST MODULE R)}

\subsection{Basic Informaxion}

This facility consists of a shailow land trench disposal (without engineered features). The cost for a shallow land disposal consists of three components: front-end facility capital cost, disposal O\&M cost, and site closure cost. Front-end facility capital cost is shown in Section 14 (cost module O), and should be added only if a new disposal facility is under consideration. Disposal of contact handled wastes at the INEL have historically ranged from $\$ 50 / \mathrm{ft}^{3}\left(100,000 \mathrm{ft}^{3} / \mathrm{yr}\right)$ to $150 / \mathrm{ft}^{3}\left(25,000 \mathrm{ft}^{3} / \text { year }\right)^{2}$. Disposal costs have varied considerably because of varying annual disposal volumes. The site closure costs and average shallow disposal costs using INEL experience for disposal are given in able 16-1. Site closure costs should be added to the shallow land disposal costs to obtain the total module $R$ cost. As an alternative, shallow land disposal costs can be compared to rates from commercial disposal sites. Dispnsal fees at commercial sites ir.lude all of the three cost components. Figure 16-1 contains estimated disposal fees at four commercial disposal sites; Hanford, WA, Beatey, NV, Ward Valley, CA, (projected costs) and Barnwell, SC.

Table 16-1. Shallow land disposal closure and capacities and costs (cost module R).

\begin{tabular}{|c|c|c|c|c|c|c|c|c|}
\hline Module & Module & Facility & Life Cycle Cost & Capacity & Unit Cost & Capacity & Cap(Tot Vol) & Unit Cost \\
\hline & Description & & $(\$ \times 1000)$ & (lbs/hr) & $(\$ / / b)$ & $(f t 3 / h r)$ & $(f+3 \times 1000)$ & $(\$ / \mathrm{ft} 3)$ \\
\hline Q_nicn & Shallow diameal & amall $+2>$ & 975000 & & INACI $>>1$ & 6 & 500 & $\operatorname{cis} 500$ \\
\hline Q-Disp & $\begin{array}{l}\text { Snallow disposal } \\
\text { Shallow disposal }\end{array}$ & med/larae & $\$ \$ 100,000$ & & INEL & 25 & 2.000 & $\$ 50.00$ \\
\hline R-close & Closure & Minimum & $\$ 32,076$ & 224 & $\$ 1.78$ & 2 & 198 & $\$ 162.00$ \\
\hline R-close & Closure & Smail & $\$ 46,464$ & 1624 & $\$ 0.35$ & 14.5 & 1,452 & $\$ 32.00$ \\
\hline R-close & Closure & Medium & $\$ 68,970$ & 5152 & $\$ 0.17$ & 46 & 3,630 & $\$ 19.00$ \\
\hline Pi-close & Closure & Large & $\$ 132,122$ & 13552 & $\$ 0.12$ & 121 & 10,164 & $\$ 13.00$ \\
\hline
\end{tabular}

\subsection{Technical Bases and Assumptions}

Since shallow land trench disposal units are commonly used by both the DOE and the commercial nuclear industry, a preconceptual design of disposal units to develop O\&M costs was not necessary. The technical bases for front-end facilities is given in Section 14. Bases for closure costs are the same as those given in Section 15.

\subsection{Cost Bases, Assumptions, and Assessments}

The cost data outlined in this section do not include surcharges that may have to be added to the standard unit rates to account for increased Curie content (remote handled waste), nonstandard packaging, excessive weight, and other parameters of the waste that requires special handling.

a. Based on RWMC contact handled LLW disposal costs calculated by Darris Bright of EG\&G Idaho, and memorandum (JAL-5-92) from J. A. Logan regarding costs of LLW disposal. 
The graph shown in Figure 16-1 illustrates costs for four commercial sites, including initial capital costs, O\&M, and closure. Costs for all sites (except Barnwell) are expected to increase in the near future because of surcharges imposed by the Low-level Radioactive Waste Policy Amendment Act (LLRWPAA). Barnwell site includes surcharges imposed as a result of the LLRWPAA. The Ward Valley facility is considered to be representative of the type of facility design that the DOE may use for future shallow land disposal. The reader is cautioned that the commercial disposal rates include capital costs, which are separately included in this report under module 0.

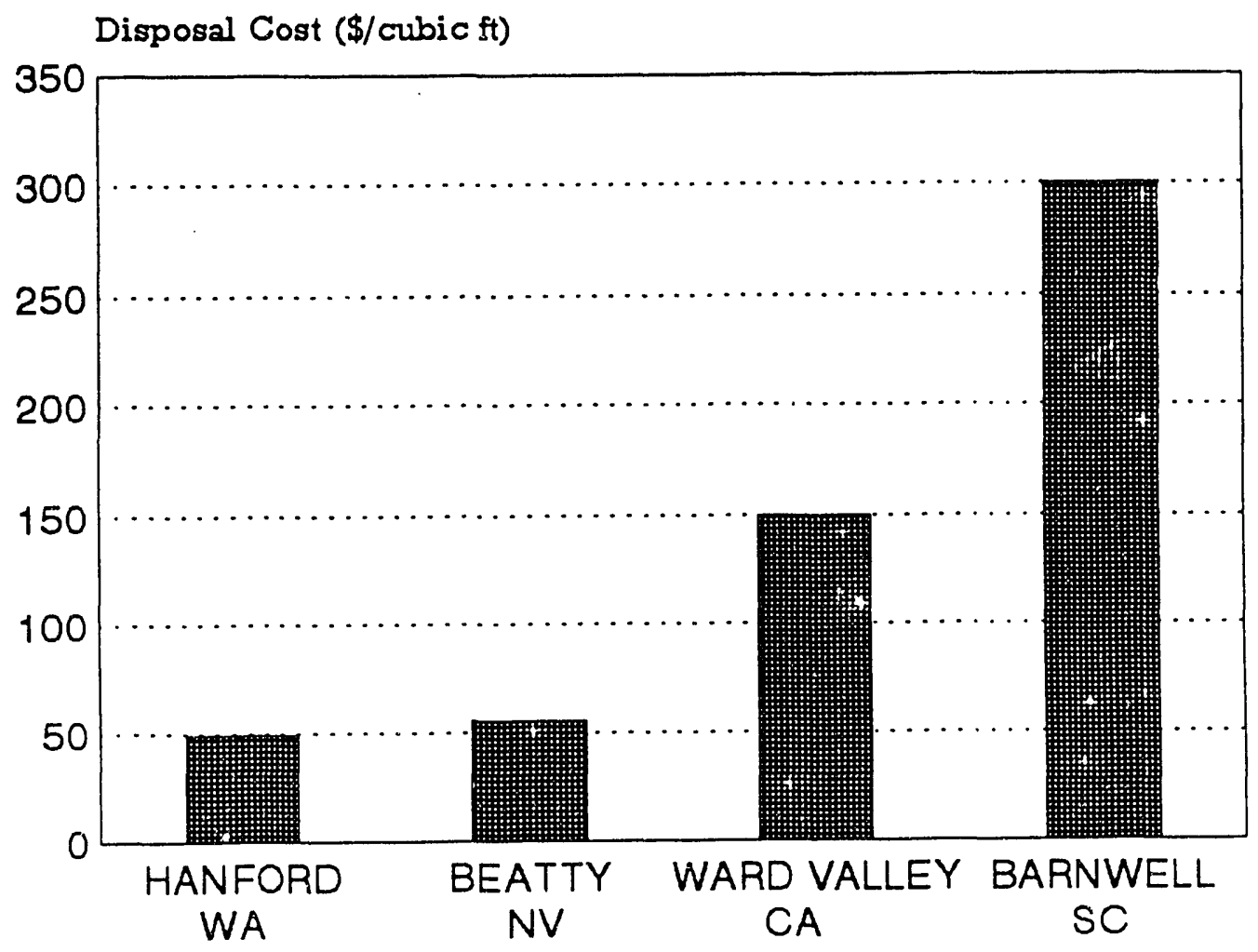

Figure 16-1. Cost comparison of commercial waste disposal facilities. 


\section{GEOLOGIC REPOSITORY FACILITY (COST MODULE S)}

\subsection{Basic Information}

This facility consists of deep geologic repository for disposal of TRUW. A planning cost estimate is made based on rates quoted in Reference 9 for WIPP.

\subsection{Technical Basis and Assumption}

It is assumed that a deep geologic repository facility will be identical to the WIPP.

\subsection{Cost Bases, Assumptions, and Assessments}

A summary of the costs for disposal at WIPP is as follows:

- Although the WIPP facility is not open, it is designated as the future storage facility for transuranic wastes (>100 nCi/g). The DOE has not formally established a disposal cost for transuranic waste at the WIPP facility.

- If cost versus capacity is used for WIPP, the disposal costs can be estimated at $\$ 740 / \mathrm{ft}^{3}$ (the data below is from Reference 9).

Estimated WIPP capital costs to date

Projected WIPP operating costs for 25 years

Total

Capacity for transuranic waste storage at WIPP Facility

Estimated transuranic waste disposal cost at WIPP

$$
\begin{aligned}
& \$ 1,000,000,000 \\
& \$ 3,750,000,000 \\
& \$ 4,750,000,000
\end{aligned}
$$

$6,450,000 \mathrm{ft}^{3}$

$$
\begin{aligned}
& \$ 4.75 \times 10 \mathrm{E} 9=\$ 736 / \mathrm{ft}^{3} \\
& 6.5 \times 10 \mathrm{E} 6 \mathrm{ft}^{3} \text { (round to } \$ 740 / \mathrm{ft}^{3} \text { ) }
\end{aligned}
$$

The above costs do not include additional costs that may be associated with disposal such as characterization and certification, packaging and transportation. 


\section{SCENARIO COSTING PROCEDURE}

This section presents guidelines to the use of PLCC estimates in this report.

\subsection{Waste Management Scenarios}

A waste management scenario is a case study of the TSD facilities and activities needed for cradle-to-grave handling of a given waste. A typical scenario may consist of the following elements:

- Generated (or stored) waste from Site 1 is shipped to Site 2 where it will be treated at a treatment facility to produce a stabilized waste form.

- Treated waste is transferred to Site 3 for interim storage.

- After the interim storage period, the waste is shipped to Site 4 for final disposal.

The report presents PLCC estimates, which are referred to as cost modules, for each TSD facility. These cost modules allow analyses of two distinctive types of waste management scenarios:

- Augmented facilities: The addition of treatment, storage, and disposal capabilities to existing waste management facilities where some or all of the front-end/back-end handling and/or partial treatment functions are already in place.

- Stand alone facilities: Scenarios that require new facilities to provide cradle-to-grave waste management.

\subsection{Cost Modules and Unit Operations}

Each discrete TSD function is referred to as a cost module. There are a total of 26 modules, listed in Table 18-1. As shown, treatment cost modules are provided for two general categories of waste: LLW/LLMW and alpha-LLW/LLMW wastes. Cost modules for storage and disposal include LLW, LLMW, alpha-LLW/LLMW, and TRUW facilities.

Each facility is broken down into separate subfunctions, referred to as unit operations. Unit operations assume inclusion of all buildings, equipment, and accessories needed to accomplish the given subfunction.

\subsection{Scenario Costing Options}

PLCC estimates in this report can be used to develop costs for waste management scenarios by two different methods: modular or unit operation.

- Modular method: This method is used when the required facilities of a given scenario are compatible with those given in this report. The user simply determines which waste management facilities are needed, the capacity required for each facility, and transportation 
Table 18-1. WMFCI cost modules.

\begin{tabular}{|c|c|c|}
\hline $\begin{array}{l}\text { Cost module } \\
\text { designation }\end{array}$ & $\begin{array}{l}\text { Facility } \\
\text { description }\end{array}$ & Application \\
\hline $\mathbf{A}$ & $\begin{array}{l}\text { LLW/LIMW and } \\
\text { Alpha- } \\
\text { LLW/LLMW } \\
\text { Treatment Front- } \\
\text { End Support }\end{array}$ & $\begin{array}{l}\text { Treatment front-end support functions, such as } \\
\text { administration, analytical laboratory, security, and } \\
\text { environmental compliance, that may be added to a } \\
\text { LLW/LLMW or an alpha-LLW/LLMW treatment } \\
\text { facility. }\end{array}$ \\
\hline B & $\begin{array}{l}\text { LLW/LLMW and } \\
\text { Alpha- } \\
\text { LLW/LLMW } \\
\text { Treatment } \\
\text { Receiving and } \\
\text { Inspection }\end{array}$ & $\begin{array}{l}\text { Treatment front-end functions: truck bay for unloading, } \\
\text { staging area, waste container inspection for radiological } \\
\text { and physical properties (for characterization), } \\
\text { temporary container storage that may be added to a } \\
\text { LLW/LLMW or an alpha-LLW/LLMW treatment } \\
\text { facility. }\end{array}$ \\
\hline $\mathrm{CA}$ & $\begin{array}{l}\text { Alpha- } \\
\text { LLW/LLMW } \\
\text { Treatment Open, } \\
\text { Dump and Sort }\end{array}$ & $\begin{array}{l}\text { Alpha-LLW/LLMW front-end treatment functions: } \\
\text { opening of containers, dumping, and sorting container } \\
\text { contents. }\end{array}$ \\
\hline $\mathrm{CL}$ & $\begin{array}{l}\text { LLW/LLMW } \\
\text { Treatment Open, } \\
\text { Dump, and Sort }\end{array}$ & $\begin{array}{l}\text { Same functions as for cost module CA except for } \\
\text { LLW/LLMW. }\end{array}$ \\
\hline $\mathrm{DA}$ & $\begin{array}{l}\text { Alpha- } \\
\text { LLW/LLMW } \\
\text { Incineration }\end{array}$ & $\begin{array}{l}\text { Incineration of alpha-LLW/LLMW combustible and } \\
\text { semicombustible solids, organic liquids, and sludge. }\end{array}$ \\
\hline DL & $\begin{array}{l}\text { LLW/LLMW } \\
\text { Incineration }\end{array}$ & $\begin{array}{l}\text { Same functions as cost module DA except for } \\
\text { LLW/LLMW. }\end{array}$ \\
\hline EA & $\begin{array}{l}\text { Alpha- } \\
\text { LLW/LLMW } \\
\text { Metal Melting }\end{array}$ & $\begin{array}{l}\text { Melting of alpha-LLW/LLMW metals including steel, } \\
\text { copper, aluminum, and lead. }\end{array}$ \\
\hline EL & $\begin{array}{l}\text { LLW/LLMW } \\
\text { Metal Melting }\end{array}$ & $\begin{array}{l}\text { Same functions as module EA except for } \\
\text { LLW/LLMW. }\end{array}$ \\
\hline FA & $\begin{array}{l}\text { Alpha-LLW } \\
\text { Shredding and } \\
\text { Compaction }\end{array}$ & $\begin{array}{l}\text { Shredding and compaction of alpha-LLW combustible, } \\
\text { semicombustible, and noncombustible waste. Waste } \\
\text { must not be subject to LDR requirements. }\end{array}$ \\
\hline FL & $\begin{array}{l}\text { LLW Shredding } \\
\text { and Compaction }\end{array}$ & Same functions as module FA except for LLW. \\
\hline GA & $\begin{array}{l}\text { Alpha- } \\
\text { LLW/LLMW } \\
\text { Solidification }\end{array}$ & $\begin{array}{l}\text { Solidification of inorganic liquids and noncombustible } \\
\text { alpha-LLW/LLMW. }\end{array}$ \\
\hline GL & $\begin{array}{l}\text { LLW/LLMW } \\
\text { Solidification }\end{array}$ & $\begin{array}{l}\text { Same functions as cost module GA except for } \\
\text { LLW/LLMW. }\end{array}$ \\
\hline HA & $\begin{array}{l}\text { Alpha- } \\
\text { LLW/LLMW } \\
\text { Vitrification }\end{array}$ & Vitrification of noncombustible alpha-LLW/LLMW. \\
\hline
\end{tabular}


Table 18-1. (continued).

\begin{tabular}{|c|c|c|}
\hline $\begin{array}{l}\text { Cost module } \\
\text { designation }\end{array}$ & $\begin{array}{l}\text { Facility } \\
\text { description }\end{array}$ & Application \\
\hline HL & $\begin{array}{l}\text { LLW/LLMW } \\
\text { Vitrification }\end{array}$ & $\begin{array}{l}\text { Same functions as cost module HA except for } \\
\text { LLW/LLMW. }\end{array}$ \\
\hline I & $\begin{array}{l}\text { Alpha } \\
\text { LLW/LLMW } \\
\text { Certification/ } \\
\text { Shipping }\end{array}$ & $\begin{array}{l}\text { Packaged waste inspection, radiological and physical } \\
\text { characterization, temporary storage, and truck } \\
\text { loading/shipping. }\end{array}$ \\
\hline JA & $\begin{array}{l}\text { Alpha } \\
\text { LLW/LLMW } \\
\text { Treatment } \\
\text { Maintenance }\end{array}$ & $\begin{array}{l}\text { Maintenance facilities for repair of failed equipment } \\
\text { and parts that are part of an alpha-LLW/LLMW } \\
\text { treatment facility. }\end{array}$ \\
\hline JL & $\begin{array}{l}\text { LLW/LLMW } \\
\text { Treatment } \\
\text { Maintenance }\end{array}$ & $\begin{array}{l}\text { Same functions as for cost module JA except for } \\
\text { LLW/LLMW. }\end{array}$ \\
\hline $\mathbf{K}$ & $\begin{array}{l}\text { Storage Front- } \\
\text { end/Back-end } \\
\text { Support }\end{array}$ & $\begin{array}{l}\text { Unloading, receiving, and inspection of incoming } \\
\text { containers; loading and shipping of outgoing } \\
\text { containers; radiological and physical characterization of } \\
\text { waste containers. }\end{array}$ \\
\hline $\mathrm{L}$ & LLW Storage & Storage of LLW containers. \\
\hline $\mathbf{M}$ & $\begin{array}{l}\text { Alpha- } \\
\text { LLW/LLMW or } \\
\text { TRUW Storage }\end{array}$ & Storage of alpha-LLW/LLMW and TRUW containers. \\
\hline $\mathbf{N}$ & LLMW Storage & Storage of LLMW containers. \\
\hline $\mathrm{O}$ & $\begin{array}{l}\text { Disposal Front-end } \\
\text { Support }\end{array}$ & $\begin{array}{l}\text { Unloading, receiving, and inspection of incoming waste } \\
\text { containers and transport of containers to disposal } \\
\text { facilities. }\end{array}$ \\
\hline $\mathbf{P}$ & $\begin{array}{l}\text { NonRCRA Waste } \\
\text { Engineered } \\
\text { Disposal }\end{array}$ & $\begin{array}{l}\text { Packaging of alpha-LLW or LLW containers into } \\
\text { concrete canisters and disposal in aboveground earth- } \\
\text { mound concrete cells. }\end{array}$ \\
\hline Q & $\begin{array}{l}\text { RCRA Waste } \\
\text { Engineered } \\
\text { Disposal }\end{array}$ & $\begin{array}{l}\text { Packaging of alpha-LLMW or LLMW containers into } \\
\text { concrete canisters and disposal in aboveground earth- } \\
\text { mound concrete cells with double liner and leachate } \\
\text { collection system. }\end{array}$ \\
\hline $\mathbf{R}$ & $\begin{array}{l}\text { LLW Shallow } \\
\text { Land Disposal }\end{array}$ & Disposal of LLW in shallow land trenches. \\
\hline S & $\begin{array}{l}\text { TRUW Geologic } \\
\text { Repository } \\
\text { Disposal }\end{array}$ & $\begin{array}{l}\text { Disposal of TRUW in a deep geologic repository such } \\
\text { as WIPP. }\end{array}$ \\
\hline
\end{tabular}


volumes and distances. Based on this information, the user calculates the total waste management costs following the procedure in Section 18.5 .

- Cost component method: PLCC estimate for each facility is comprised of six cost components (see Appendix A). The cost component method should be used if the reader has access to an updated cost data on a given component. The reader may simply replace the updated costs in the appropriate table and calculate a new PLCC estimate by adding the six components. Once a modified PLCC estimate is determined, the cost for the overall scenario is calculated in the same manner as the modular method.

\subsection{Information Required to Cost a Scenario}

To use either the modular or unit operation method, the following items must be known to the user:

1. Waste radiological category: The user must be knowledgeable about radioactive waste categories as defined in DOE orders (e.g., 5280.2A), since the waste must be classified into one of the following general categories:

a. TRUW: Generally a defense related radioactive waste with transuranic concentration above $100 \mathrm{nCi} / \mathrm{g}$.

b. Alpha-LLW or Alpha-LLMW: Generally defense related radioactive wastes that have a transuranic concentration in the range of $10-100 \mathrm{nCi} / \mathrm{g}$. Alpha-LLMW is the same as alpha-LLW with the exception that it is subject to control under RCRA.

c. LLW or LLMW: Wastes generated from nuclear reactor operation or nuclear research. Defense related LLW or LLMW has a transuranic concentration below $10 \mathrm{nCi} / \mathrm{g}$. LLMW is the same as LLW with the exception that it is subject to control under RCRA.

2. Waste treatment category: The user must have sufficient knowledge about the waste properties to select one of the five treatment facilities described in this report. Various waste categories are described in Appendix A.

3. Input waste flow rate(s): The user must know the weight of the waste to be treated. Input waste is converted to pounds per hour $(\mathrm{lbs} / \mathrm{h})$ by dividing the total weight by 80,640 hours for a 20 -year life cycle. The 80,640 hours is the total processing hours based on 24 hours per day, 240 days per year, for 20 years at $70 \%$ availability.

4. Facility locations and transportation distances: The user must know which DOE site(s) will house the facilities and determine whether the facilities will be a stand-alone or augmented type. 


\subsection{Scenario Costing Procedure}

The scenario costing procedure (schematically shown in Figure 1-3) allows the user to develop the overall cost of a given scenario by following seven steps: (a) define scenarios, (b) define parameters, (c) develop treatment costs, (d) develop storage costs, (e) develop disposal costs, (f) develop transportation costs, and ( $\mathrm{g}$ ) develop PLCC costs. Each of these seven steps are described below. A worksheet is provided in Appendix A to assist in developing PLCC costs from this procedure.

\subsubsection{Define Scenarios}

The user must develop a strategy for cradle-to-grave management of the given waste stream by establishing the information listed below (see Figure 1-3 for a block diagram of a sample scenario).

- Waste source and location: Define waste streams, characteristics, and location where the waste is generated or stored.

- Treatment facility types and location: Define types and location of treatment facilities needed for each waste.

- Interim storage period and location: Define types and location of interim storage facilities needed for each waste.

- Disposal type and location: Define types and location of disposal facilities needed for each waste.

- For each treatment, storage, and disposal facility, the user must determine whether the facilities will be stand alone or augmented to an existing operation that has common support functions.

\subsubsection{Define Parameters}

Parameters required for each scenario include the following:

- Treatment facility input waste feed rates: The basic requirements for the scenario are input waste feed rates. The total weight of the input waste (in pounds) is then established for each type of facility. The total weight must be divided by 80,640 hours to establish facility capacity in $\mathrm{lbs} / \mathrm{h}$.

- Treatment facility output waste flow rates: Output (treated) waste flow rates for each type of treatment facility should be determined in $\mathrm{ft}^{3} / \mathrm{h}$. The treatment facility input waste feed rate (lbs/h) is multiplied by the output waste multiplication weight factor (see Table 18-2) to obtain the output waste mass flow rate $(\mathrm{lbs} / \mathrm{h})$. Then, the output flow ratc is divided by the treated waste density to get waste volumetric flow rate $\left(\mathrm{ft}^{3} / \mathrm{h}\right)$. 
Table 18-2. Waste treatment weight conversion factors.

\begin{tabular}{|c|c|c|}
\hline Treatment facility & $\begin{array}{l}\text { Output waste } \\
\text { conversion } \\
\text { weight factor }\end{array}$ & $\begin{array}{l}\text { Treated waste } \\
\text { density } \\
\left(\mathrm{lb} / \mathrm{ft}^{3}\right)\end{array}$ \\
\hline $\begin{array}{l}\text { Incineration } \\
\text { Solidified waste ash } \\
\text { (in concrete) }\end{array}$ & 0.493 & 112 \\
\hline $\begin{array}{l}\text { Metal melting/recovery } \\
\text { Metals (cast ingots) } \\
\text { Solidified waste } \\
\text { sludge and slag } \\
\text { (concrete) }\end{array}$ & $\begin{array}{l}1.000 \\
0.306\end{array}$ & $\overline{112}$ \\
\hline $\begin{array}{l}\text { Shredding/compaction } \\
\text { Compacted waste (in } \\
\text { overpack) } \\
\text { Solidified liquid waste }\end{array}$ & $\begin{array}{l}1.142 \\
0.209\end{array}$ & $\begin{array}{l}10-70 \\
112\end{array}$ \\
\hline $\begin{array}{l}\text { Solidification } \\
\text { Solidified solid, } \\
\text { liquid, sludge waste } \\
\text { (in concrete) }\end{array}$ & 2.963 & 112 \\
\hline $\begin{array}{l}\text { Vitrification waste } \\
\text { Vitreous waste } \\
\text { (rock/glass material) } \\
\text { Solidified liquid and } \\
\text { sludge waste (in } \\
\text { concrete) }\end{array}$ & $\begin{array}{l}0.958 \\
0.224\end{array}$ & $\begin{array}{l}187 \\
112\end{array}$ \\
\hline
\end{tabular}

- Storage facility input/output waste flow rates: Input waste flow rate is determined based on the scenario and is generally equal to the waste output from the treatment facilities. Waste output rate is also dependent on the scenario and is generally the same as the input rate, but can be adjusted to suit other requirements of the scenario. Flow rates should be developed in $\mathrm{ft}^{3} / \mathrm{h}$.

- Disposal facility input waste flow rates: Input waste flow rate is determined based on the scenario and should be generally the same as the waste output from the treatment facilities. Waste output rate from storage facilities must also be considered. Flow rates should be developed in $\mathrm{ft}^{3} / \mathrm{h}$. 
- Transportation distances: Transportation distances (in miles) should be calculated for the TSD facility incoming wastes.

Once the parameters are established for the various facilities in the scenario, the user should proceed with developing costs as described in Sections 18.5.3 through 18.5.7. Summary cost/capacity tables for all treatment, storage, and disposal modules are provided in Tables 18-3, 18-4, and 18-5. These tables may be referenced to develop PLCC costs for treatment, storage, and disposal facilities in the following sections. 
Table 18-3. Summary costs and capacities for treatment facilities.

\begin{tabular}{|c|c|c|c|c|c|c|c|c|}
\hline Mod. & Module & \multicolumn{3}{|c|}{ Facility Life Cycle Cos (Capacity } & \multicolumn{3}{|c|}{ Unit Cost Capacity Cap(Tot Vol) } & Unit Cost \\
\hline & Description & & $(\$ \times 1000)$ & $(\mathrm{lbs} / \mathrm{hr})$ & $(\$ / / b)$ & $(\mathrm{ft} / \mathrm{hr})$ & $(f t 3 \times 1000)$ & $(\$ / f t 3)$ \\
\hline & & & & & & & & \\
\hline $\bar{A}$ & Treatment Support & Small & $\$ 128,897$ & 200 & $\$ 7.99$ & 6 & 461 & $\$ 279.72$ \\
\hline A & Treatment Support & Medium & $\$ 290,158$ & 5,600 & $\$ 0.64$ & 160 & 12,902 & $\$ 22.49$ \\
\hline A & Treatment Support & Large & $\$ 530,763$ & 12,500 & $\$ 0.53$ & 357 & 28,800 & $\$ 18.43$ \\
\hline 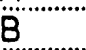 & Treatment Rec./Inso. & Small & $\$ 62,612$ & 200 & $\$ 3.88$ & 6 & 461 & $\$ 135.88$ \\
\hline $\mathrm{B}$ & Treatment Rec./Insp. & Medium & $\$ 128,900$ & 5,600 & $\$ 0.29$ & 160 & 12,902 & $\$ 9.99$ \\
\hline $\mathrm{B}$ & Treatment Rec./Insp. & Large & $\$ 204,179$ & 12.500 & $\$ 0.20$ & 357 & 28,800 & $\$ 7.09$ \\
\hline $\mathrm{CL}$ & Front-end Treatment & Smail & $\$ 170,095$ & 200 & $\$ 10.55$ & 6 & 461 & $\$ 369.13$ \\
\hline$C L$ & Front-end Treatment & Medium & $\$ 689,326$ & 5,600 & $\$ 1.53$ & 160 & 12,902 & $\$ 53.43$ \\
\hline CL & Frort-end Treatment & Large & $\$ 1,522,432$ & 12,500 & $\$ 1.51$ & 357 & 28,800 & $\$ 52.86$ \\
\hline $\mathrm{CA}$ & Front-end Treatment & Smail & $\$ 216.026$ & 200 & $\$ 13.39$ & 6 & 461 & $\$ 468.81$ \\
\hline $\mathrm{CA}$ & Front-end Treatment & Medium & $\$ 1,182,462$ & 4.500 & $\$ 3.26$ & 129 & 10,368 & $\$ 114.05$ \\
\hline $\mathrm{CA}$ & Front-end Treatment & Larqe & $\$ 1,419,910$ & 7,700 & $\$ 2.29$ & 220 & 17,741 & $\$ 80.04$ \\
\hline DL' & Incineration & Small & $\$ 296,245$ & 200 & $\$ 18.37$ & 6 & 461 & $\$ 642.89$ \\
\hline $\mathrm{DL}$ & Incineration & Medium & $\$ 453,292$ & 1,000 & $\$ 5.62$ & 29 & 2.304 & $\$ 196.74$ \\
\hline $\mathrm{DL}$ & Incineration & Large & $\$ 624,390$ & 2,000 & $\$ 3.87$ & 57 & 4,608 & $\$ 135.50$ \\
\hline$D A$ & Incineration & Small & $\$ 364,684$ & 150 & $\$ 30.15$ & 4 & 346 & $\$ 1.055 .22$ \\
\hline $\mathrm{DA}$ & Incineration & Medium & $\$ 536,989$ & 1,000 & $\$ 6.66$ & 29 & 2,304 & $\$ 233.07$ \\
\hline DA & Incineration & Large & $\$ 732.819$ & 2,000 & $\$ 4.54$ & 57 & 4.608 & $\$ 159.03$ \\
\hline EL & Metal Melting & Small & $\$ 140,950$ & 50 & $\$ 34.96$ & 1 & 115 & $\$ 1,223.52$ \\
\hline EL & Metal Melting & Medium & $\$ 293,306$ & 1,600 & $\$ 2.27$ & 46 & 3,686 & $\$ 79.56$ \\
\hline$E L$ & Metal Melting & Large & $\$ 335,527$ & 2,500 & $\$ 1.66$ & 71 & 5,760 & $\$ 58.25$ \\
\hline$E A$ & Metal Melting & Small & $\$ 194,798$ & 60 & $\$ 40.26$ & 2 & 138 & $\$ 1,409.13$ \\
\hline EA & Metal Melting & Medium & $\$ 372,028$ & 600 & $\$ 7.69$ & 17 & 1,382 & $\$ 269.12$ \\
\hline$E A$ & Metal Melting & Large & $\$ 469,314$ & 1,000 & $\$ 5.82$ & 29 & 2,304 & $\$ 203.70$ \\
\hline $\mathrm{FL}-$ & Shred/Compact & Small & $\$ 100,758$ & 300 & $\$ 4.16$ & 9 & 691 & $\$ 145.77$ \\
\hline$F$ & Shred/Compact & Medium & $\$ 120.979$ & 1,000 & $\$ 1.50$ & 29 & 2,304 & $\$ 52.51$ \\
\hline$F L$ & Shred/Compact & Large & $\$ 235,121$ & 4,000 & $\$ 0.73$ & 114 & 9,216 & $\$ 25.51$ \\
\hline FA & Shred/Compact & Small & $\$ 111,222$ & 100 & $\$ 13.79$ & 3 & 230 & $\$ 482.73$ \\
\hline$F A$ & Shred/Compact & Medium & $\$ 126,232$ & 1.000 & $\$ 1.57$ & 29 & 2,304 & $\$ 54.79$ \\
\hline FA & Shred/Compact & Large & $\$ 255,361$ & 1,500 & $\$ 2.11$ & 43 & 3,456 & $\$ 73.89$ \\
\hline GL & Solidification & Small & $\$ 162,181$ & 400 & $\$ 5.03$ & 11 & 922 & $\$ 175.98$ \\
\hline$G L^{\prime}$ & Solidification & Medium & $\$ 260,896$ & 1,000 & $\$ 3.24$ & 29 & 2,304 & $\$ 113.24$ \\
\hline$G L$ & Solidification & Large & $\$ 451,794$ & 2,000 & $\$ 2.80$ & 57 & 4,608 & $\$ 98.05$ \\
\hline GA & Solidification & Small & $\$ 200,672$ & 70 & $\$ 35.55$ & 2 & 161 & $\$ 1,244.25$ \\
\hline$G A$ & Solidification & Medium & $\$ 311,764$ & 700 & $\$ 5.52$ & 20 & 1,613 & $\$ 193.31$ \\
\hline$G A$ & Solidification & Large & $\$ 431,332$ & 1,200 & $\$ 4.46$ & 34 & 2,765 & $\$ 156.01$ \\
\hline $\mathrm{HL}$ & Vitrification & Small & $\$ 316,401$ & 300 & $\$ 13.08$ & 9 & 691 & $\$ 457.76$ \\
\hline $\mathrm{HL}$ & Vitrification & Medium & $\$ 430,303$ & 1.000 & $\$ 5.34$ & 29 & 2,304 & $\$ 186.76$ \\
\hline$H L$ & Vitrification & Large & $\$ 587.311$ & 2.000 & $\$ 3.64$ & 57 & 4,608 & $\$ 127.45$ \\
\hline $\mathrm{HA}$ & Vitrification & Small & $\$ 359,866$ & 300 & $\$ 14.88$ & 9 & 691 & $\$ 520.64$ \\
\hline $\mathrm{HA}$ & Vitrification & Medium & $\$ 490,069$ & 1,200 & $\$ 5.06$ & 34 & 2,765 & $\$ 177.25$ \\
\hline $\mathrm{HA}$ & Vitrification & Large & $\$ 655,339$ & 2,000 & $\$ 4.06$ & 57 & 4,608 & $\$ 142.22$ \\
\hline 1 & Cert./Shipment & Small & $\$ 69,315$ & 450 & $\$ 1.91$ & 4 & 324 & $\$ 213.94$ \\
\hline i" & Cert./Shipment & Medium & $\$ 127,960$ & 6,235 & $\$ 0.25$ & 56 & 4,489 & $\$ 28.50$ \\
\hline i“ & Cert./Shipment & Large & $\$ 239,201$ & 18,200 & $\$ 0.16$ & 163 & 13,104 & $\$ 18.25$ \\
\hline$J L$ & Treatment Maint. & Small & $\$ 36,887$ & 450 & $\$ 1.02$ & 4 & 324 & $\$ 113.85$ \\
\hline JL & Treatment Maint. & Medium & $\$ 72,588$ & 6.235 & $\$ 0.14$ & 56 & 4,489 & $\$ 16.17$ \\
\hline$J$ & Treatment Maint. & Large & $\$ 136.592$ & 18.200 & $\$ 0.09$ & 163 & 13,104 & $\$ 10.42$ \\
\hline $\mathrm{JA}$ & Treatment Maint. & Small & $\$ 38,091$ & 450 & $\$ 1.05$ & 4 & 324 & $\$ 117.56$ \\
\hline JA & Treatment Maint. & Medium & $\$ 73,048$ & 6.235 & $\$ 0.15$ & 56 & 4,489 & $\$ 16.27$ \\
\hline $\mathrm{JA}$ & Treatment Maint. & Large & $\$ 156,741$ & 18,200 & $\$ 0.11$ & 163 & 13,104 & $\$ 11.96$ \\
\hline
\end{tabular}


Table 18-4. Summary costs and capacities for sturage facilities.

\begin{tabular}{|c|c|c|c|c|c|c|c|c|}
\hline Module & Module & Facility & Life Cycle Cost & Capacity & Unit Cs st & Capacity & Cap(Tot Vol & Unit Cost \\
\hline & Description & & $(\$ \times 1000)$ & $(1 \mathrm{bs} / \mathrm{hr} r)$ & $(\$ / 1 \mathrm{~b}$ & $(1+3 / h r)$ & $(1+3 \times 1000)$ & $(\$ / f t 3)$ \\
\hline & & & & & & & & \\
\hline$\alpha$ & Storage support & Smail & $\$ 155,073$ & 560 & $\$ 3.43$ & 5 & 40 & $\$ 384.6$ \\
\hline$K$ & Storage support & Medium & 997 & 3360 & $\$ 1.18$ & 30 & 2,41 & $\$ 132.2$ \\
\hline K & Storage support & Large & $\$ 611,128$ & 9744 & $\$ 0.78$ & 87 & 7,01 & $\$ 87.11$ \\
\hline L,MN & Storage & Small & $\$ 51,856$ & 560 & $\$ 1.15$ & 5 & 40 & $\$ 128.61$ \\
\hline L.M.N & Storage & Medium & $\$ 99,847$ & 1232 & $\$ 1.01$ & 11 & 88 & $\$ 112.56$ \\
\hline$L, M . N$ & Storage & Large & $\$ 405,883$ & 9744 & $\$ 0.52$ & 87 & 7,01 & $\$ 57.85$ \\
\hline
\end{tabular}

Table 18-5. Summary costs and capacities for disposal facilities.

\begin{tabular}{|c|c|c|c|c|c|c|c|c|}
\hline Module & Module & Facility & Life Cycle Cost & Capacity & Unit Cost & Capacity & Cap(Tot Vol) & Unit Cost \\
\hline & Description & & $(\$ \times 1000)$ & $(\mathrm{lbs} / \mathrm{hr})$ & $(\$ / / b)$ & $(\mathrm{ft} 3 / \mathrm{hr})$ & $(f+3 \times 1000)$ & $(\$ / f t 3)$ \\
\hline & & & & & & & & \\
\hline O & Disposal Support & Minimum & $\$ 159,705$ & 224 & $\$ 8.84$ & 2 & 161 & $\$ 990.23$ \\
\hline 0 & Disposal Support & Smaill & $\$ 328,104$ & 1624 & $\$ 2.51$ & 14.5 & 1,169 & $\$ 280.60$ \\
\hline 0 & Disposal support & Medium & $\$ 441,571$ & 5152 & $\$ 1.06$ & 46 & 3,709 & $\$ 119.04$ \\
\hline 0 & Disposal Support & Large & $\$ 697,007$ & 13552 & $\$ 0.64$ & 121 & 9,757 & $\$ 71.43$ \\
\hline$P$ & Engr. Disposal & Minimum & $\$ 327,121$ & 224 & $\$ 18.11$ & 2 & 161 & $\$ 2,028.28$ \\
\hline$p$ & Engr. Disposal & Smail & $\$ 491,233$ & 1624 & $\$ 3.75$ & 14.5 & 1,169 & $\$ 420.12$ \\
\hline $\mathrm{P}$ & Engr. Disposal & Medium & $\$ 886,506$ & 5152 & $\$ 2.13$ & 46 & 3,709 & $\$ 238.99$ \\
\hline$P$ & Engr. Disposal & Large & $\$ 2,146,360$ & 13552 & $\$ 1.96$ & 121 & 9,757 & $\$ 219.97$ \\
\hline QRCRA & Engr. Disposal & Minimum & $\$ 334,328$ & 224 & $\$ 18.51$ & 2 & 161 & $\$ 2.072 .97$ \\
\hline $\mathrm{RA}$ & Engr. Disposal & Smail & $\$ 495,628$ & 1624 & $\$ 3.78$ & 14.5 & 1.169 & $\$ 423.87$ \\
\hline$R A$ & Engr. Disposal & Medium & $\$ 897,026$ & 5152 & $\$ 2.16$ & 46 & 3,709 & $\$ 241.82$ \\
\hline QRCRA & Engr. Disposai & Large & $\$ 2,168,827$ & 13552 & $\$ 1.98$ & 121 & 9,757 & $\$ 222.27$ \\
\hline R-Disp & Shallow disposal & smail & $\$ 75,000$ & & NEL & 6 & 500 & $\$ 150.00$ \\
\hline R-Disp & Shallow disposal & med/large & $\$ 100,000$ & & INEL & 25 & 2.000 & $\$ 50.00$ \\
\hline R-close & Closure & Minimum & $\$ 32,076$ & 224 & $\$ 1.78$ & 2 & 198 & $\$ 162.00$ \\
\hline R-close & Closure & Small & $\$ 46,464$ & 1624 & $\$ 0.35$ & 14.5 & 1,452 & $\$ 32.00$ \\
\hline R-close & Closure & Medium & $\$ 68,970$ & 5152 & $\$ 0.17$ & 46 & 3,630 & $\$ 19.00$ \\
\hline R-close & Closure & Large & $\$ 132,132$ & 13552 & $\$ 0.12$ & 121 & 10,164 & $\$ 13.00$ \\
\hline S & Geologic Disposal & ail & $\$ 4,750,000$ & & WPP & 80 & 6,450 & $\$ 736.43$ \\
\hline
\end{tabular}




\subsubsection{Develop Treatment Costs}

Treatment facility costs consist of three facility categories; front-end support, treatment, and back-end support facilities. If the desired treatment facility is an addition to an existing facility, then only the cost for the treatment facility must be developed. However, if the facility is new, then costs for the front-end and back-end support functions must also be included.

Once the type of facilities have been established, the user can obtain PLCC estimates by selecting one of the cost modules that is closest to the required capacity from the cost modules presented in Table 18-3 for these facilities.

\subsubsection{Develop Storage Costs}

Storage costs consist of two categories: front-end/back-end support and storage facilities. If the desired storage facility is an addition to an existing facility, then only the cost for the storage facility must be developed. However, if a the facility is new, then costs for the front-end/back-end support facilities must also be included.

Once the type of facilities have been established, the user can obtain PLCC estimates for the front-end/back-end facility by selecting one of the cost modules that is closest to the required capacity from the cost-versus-capacity graphs presented for these facilities. The storage cost should be obtained by selecting one of the cost modules from Table 18-4 that is closest to the required capacity and multiply the storage unit rate (Table 12-2) of this module by the total volume of waste.

\subsubsection{Develop Disposal Cost}

Disposal costs consist of two categories; front-end support and disposal facilities. The procedure to determine disposal costs is the same one used to determine the storage cost. Use Table 18-5 to obtain cost and capacity information.

\subsubsection{Develop Transportation Costs}

Transportation costs are calculated by multiplying the volume of the waste to be shipped by the following factors:

- Up to 30 miles: $\$ 1.00 / \mathrm{ft}^{3}$

- $\quad 30$ to 300 miles: $\$ 1.72 / \mathrm{ft}^{3}$

- $\quad 300$ to 500 miles: $\$ 2.26 / \mathrm{ft}^{3}$

\subsubsection{Total PLCC Costs}

Add items from 18.5.1-18.5.6 to yield the total PLCC estimates for the selected waste management scenario. 


\subsection{Limitations}

WMFCI is a useful tool for developing PLCC estimates of DOE site-wide waste management scenarios. Costs are developed for initial project planning, demonstration, design, construction of production facility, 20-year operation and maintenance, and decommissioning and closure. Only facilities subject to the following key conditions are appropriate for the cost data presented in WMFCI:

1. Facilities designated as a Major Project or Major System Acquisition (MSA) project as defined in DOE Order 4700.1 Project Management System. To apply WFMCI, each project must go through the DOE acquisition process defined by this order. Key milestones for the designation process and a schedule for typical waste management facility licensing, construction, and operation are given in Figure 18-1.

2. Facilities are subject to

a. Environment, safety, and health requirements including NEPA and safety assurance reviews according to DOE orders and regulations (See Environmental Compliance Guide, DOE/EV-1032). Activities include the preparation of an Environmental Impact Statement, Safety Analysis Report, and related activities.

b. RCRA Permitting-TSD permit.

c. Other permits such as National Air Emission Standard for Hazardous Air Pollutants, Clean Air Act, and State and local permits.

c. General Design criteria given in DOE Order 6430.1A.

3. The five treatment cost modules were strategically selected such that a majority of waste streams from a typical DOE site can be addressed. However, there is a wide range of DOE special waste streams that may not be specifically treatable by the given processes. In such situations, the unit operations of the given facility must be revised to develop costs for special waste streams.

4. LCC estimates are based on conditions at the INEL. Cost differences from site specific cost factors are assumed to be within the variance limits of this cost estimate. Table 18-6 provides a guide for comparing DOE site cost factors relative to the INEL. ${ }^{e}$

e. Cost factors are based from the report titled Mixed Waste Treatment Project Process Systems and Facilities Design Study and Cost Estimates and verbal confirmation by Brian Marais from Bechtel. Data used to generate the rate table are based on a combination of Means Construction Cost Data and Bechtel historical cost data. 


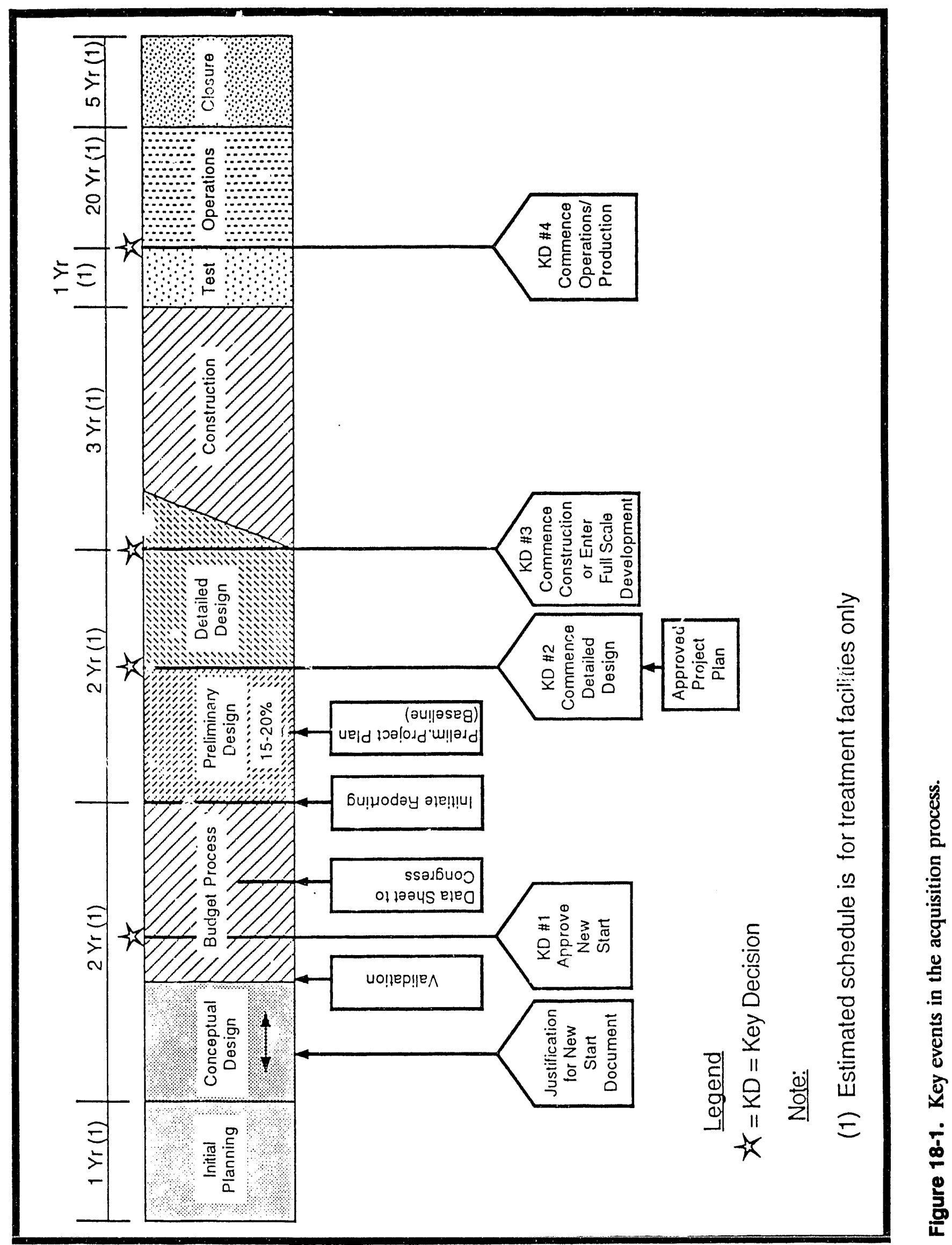


Table 18-6. Site specific cost factors.

\begin{tabular}{lcccc}
\hline \multicolumn{1}{c}{$\begin{array}{c}\text { Site } \\
\text { (index area) }\end{array}$} & $\begin{array}{c}\text { Material } \\
\text { index }^{\mathrm{a}}\end{array}$ & $\begin{array}{c}\text { Installation } \\
\text { index }^{\mathrm{a}}\end{array}$ & $\begin{array}{c}\text { State sale } \\
\text { tax rate }\end{array}$ & $\begin{array}{c}\text { Cost factor (CF) } \\
\text { relative to INEL }^{\mathrm{b}}\end{array}$ \\
\hline $\begin{array}{l}\text { INEL } \\
\text { (Boise) }\end{array}$ & 98.9 & 88.4 & $5.5 \%$ & 1.0 \\
$\begin{array}{l}\text { Los Alamos National } \\
\text { Laboratory } \\
\text { (Albuquerque) }\end{array}$ & 101.7 & 82.7 & $4.75 \%$ & 0.983 \\
$\begin{array}{l}\text { Lawrence Livermore } \\
\begin{array}{l}\text { National Laboratory } \\
\text { (Stockton) }\end{array}\end{array}$ & 99.2 & 116.8 & $8.25 \%$ & 1.130 \\
$\begin{array}{l}\text { Oak Ridge (Knoxville) } \\
\text { Portsmouth } \\
\text { (Columbus) }\end{array}$ & 98.1 & 72.4 & $5.5 \%$ & 0.935 \\
$\begin{array}{l}\text { Rocky Flats (Denver) } \\
\text { Hanford (Spokane) }\end{array}$ & 99.5 & 95.9 & $5.0 \%$ & 1.031 \\
& 101.1 & 86.9 & $3.0 \%$ & 0.998 \\
$\begin{array}{l}\text { Savannah River } \\
\text { (Columbia) }\end{array}$ & 97.8 & 69.7 & $6.5 \%$ & 1.054 \\
\hline & & & & \\
\hline
\end{tabular}




\section{REFERENCES}

1. Mayberry, J. L. et al., Preliminary Systems Design Study Report, EGG-WTD-9594, Volumes I through VIII, July 1991.

2. Feizollahi, F. et al., Preliminary Stored Waste Systems Design Study for Low-Level TRU Waste Treatment Report, EGG-WTD-10254, DRAFT, May 1992.

3. Youngblood, A., and S. Booth, Environmental Remediation Cost and Risk Estimating Software Summary, Los Alamos National Laboratory, LA-UR-92-1932.

4. Feizollahi, F., and D. Shropshire, Waste Management Facility Cost Information Estimating Data, WTD-92-046, 1992.

5. Sappok, M., and G. Rettig, "Results of Melting Large Quantities of Radioactive Metallic Scrap," Proceedings of Spectrum 92 International Topical Meeting, Nuclear and Hazardous Waste Management, Volume 1, page 120, August 23-27, 1992, Boise, Idaho.

6. Roads, A. S., "A Performance Assessment of Radioactive Waste Encapsulated in Iron-Enriched Basalt and Disposed at the Idaho National Engineering Laboratory's Radioactive Waste Management Complex," Proceedings at Spectrum 92 International Topical Meeting, Nuclear and Hazardous Waste Management, Volume 2, page 1442, August 23-27, 1992, Boise, Idaho.

7. "Illinois Low-Level Radioactive Waste Disposal Facility Application," Chapters 3 and 10, May 15, 1991.

8. "Conceptual Design Report-Alternative Concepts for Low-Level Radioactive Waste Disposal" National Low-Level Waste Management Program, June 1987, DOE/LLW-60T.

9. Schlueter, R., et al., Low Level and Transuranic Waste Transportation, Disposal and Facility Decommissioning Cost Sensitivity Analysis, EGG-WTD-10092, March 1992. 


\section{Appendix A}

Methodology, Assumptions, and Bases 


$$
\text { A-2 }
$$




\section{Appendix A}

\section{Methodology, Assumptions, and Bases}

The cost estimating methodology, assumptions, and technical bases that are used to develop planning life-cycle cost (PLCC) estimates are presented below. Specific additional assumptions and bases for each cost module are given in the main body of this report and EG\&G Idaho internal report, "Waste Management Facility Cost Information Estimating Data" (WTD-92-049).

\section{A.1 COST ESTIMATING METHODOLOGY}

The cost estimating approach, shown in Figure 1-2 of the text, is based on the development of well documented PLCC estimates for various facility capacities. Initially, a capacity range for each type of facility was established by studying the stored and newly generated wastes at various existing DOE sites. Data from the study defined baseline capacities for three different facility sizes (small, medium, and large). These capacities are facility specific and have been defined in the main body of this report under the appropriate sections.

Using the three capacities, a preconceptual design package for each cost module was developed and used as the basis for PLCC cost estimates. Each preconceptual design package includes a process functional diagram with mass flow rates, scoping study layout, and summary functional and operational requirement (F\&OR). The design packages utilize as much of the data from existing or planned DOE facilities as possible. New designs were generated only if existing data were not available.

The process functional diagrams and scoping study layout drawings were developed to the individual unit operations level. After unit operations were defined, major equipment lists and building square footage requirements were established for each unit operation and released for cost estimating.

Costs for each facility are divided into six components, each of which is estimated separately. Equipment costs were obtained by soliciting budgetary costs from the suppliers, using existing data, or making engineering judgements. Building costs were estimated by multiplying the unit operation square footage by the building cost unit rates. After the five components are estimated, they are added to obtain the total facility PLCC estimate.

To facilitate cost estimating flexibility, the front-end/back-end functions (e.g., receiving/staging/storage, incoming waste assay/inspection, incoming waste open/dump/sort, outgoing waste assay/certification, and support facilities such as administration, maintenance shop, analytical laboratory) of each treatment, storage, and disposal facility are estimated as separate cost modules. This approach allows consideration of scenarios that involve existing facilities where some or all of the front-end/back-end functions are already in place. 


\section{A.2 WMFCI MODEL}

To develop the Waste Management Facility Cost Information (WMFCI) model, cost estimating data were entered into an interlinked spreadsheet in Lotus 123 software. The model outlines detailed costs, cost factors, and unit rates for each cost module. A hard copy of the spreadsheets is included in EG\&G Idaho report WTD-92-046.

\section{A.3 TECHNICAL BASES AND ASSUMPTIONS}

Technical assumptions that apply to all cost modules in this report are discussed in the following sections. Facility specific assumptions are given in the main body of this report.

\section{A.3.1 Input Waste Characteristics}

It is assumed that waste that does not have free water is received at the treatment facilities in drums, boxes, or metal bins. Liquid wastes are piped into the treatment facilities. Received waste will fall in one of the following three categories (see Figure A-1):

- $\quad$ Dry active waste (DAW): Dry active waste consists of discarded components, disposed garments, housekeeping waste, dirt, debris, metals, and similar material. It is assumed that DAW, when shipped to the treatment facilities in containers, are generally composed of $25 \%$ combustibles, $25 \%$ semicombustibles (a mixture of $50 \%$ combustibles with $50 \%$ noncombustibles) $10 \%$ noncombustibles, $8.5 \%$ metals, $30 \%$ homogeneous, $1.5 \%$ special waste. The composition of the combustibles portion of DAW are shown in Table A-1. Various solid waste categories are as follows:

- DAW-1, Combustible solids: Combustible solids include waste paper, wood, plastics, clothing, rubber, etc.

- DAW-2, Semicombustible solids: Semicombustibles include benelex and plexiglass, cemented or uncemented dry organic sludge, volatile organic chemical (VOC) contaminated soil/debris, asphalt, graphite, molds, insulation spent filters, etc.

- DAW-3, Noncombustible solids: Noncombustible solids include ash, soil, concrete, brick, construction debris, etc.

- DAW-4, Contaminated metals: This waste includes ferrous and nonferrous metal waste that is delivered to the treatment facilities in bulk forms, separate from and in addition to loose metal waste, which is mixed with other DAW categories. Subcategories are as follows:

- DAW-4a, Bulk metals: Bulk metals include steel, metal, aluminum, copper, special metals, etc.

- DAW-4b, Lead: This category includes lead bricks, gloves, leaded rubber, lead slabs, etc. 


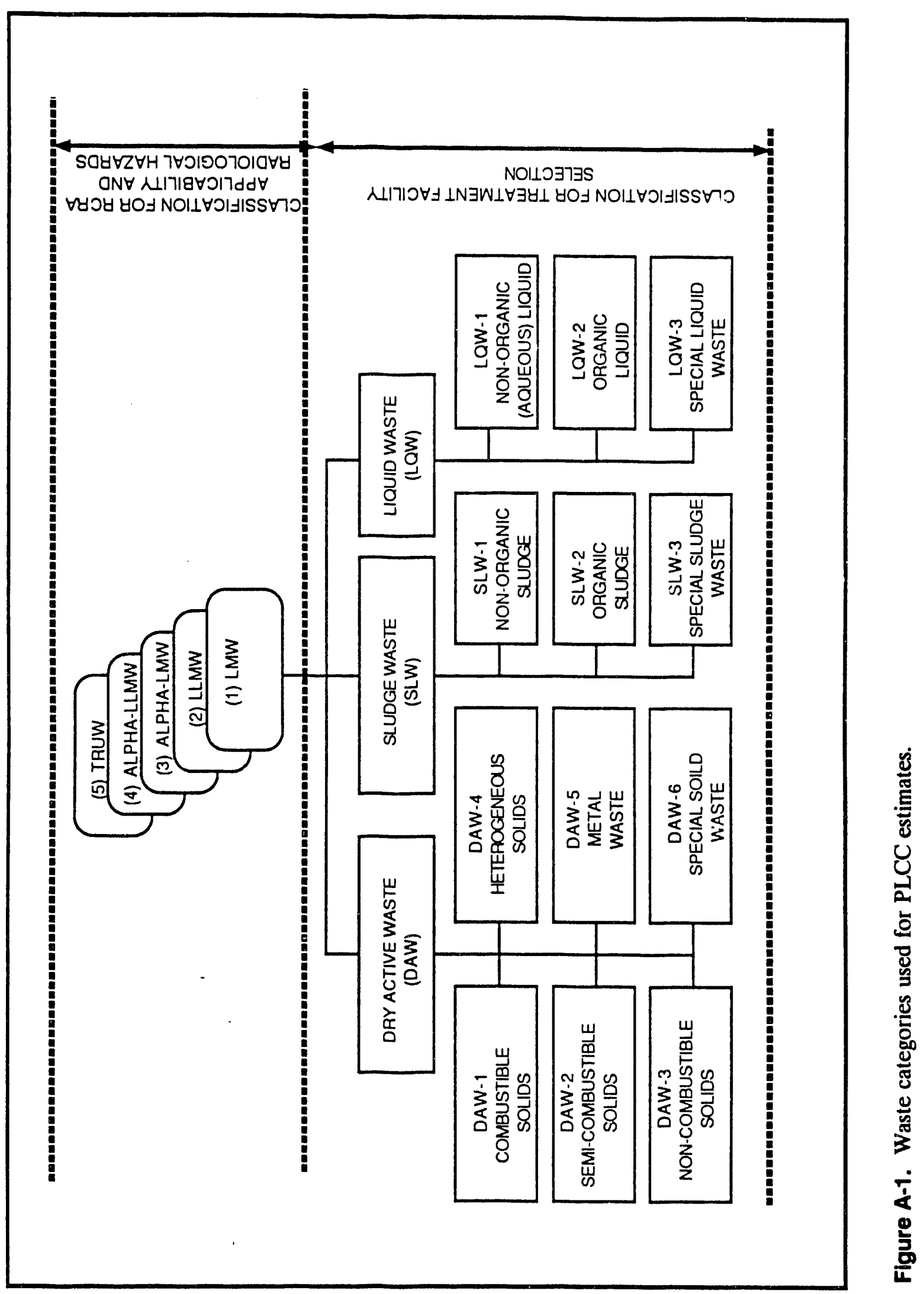


Table A-1. Composition of the combustible portion of DAW.

\begin{tabular}{lrr}
\hline Waste type & Percent & $\begin{array}{r}\text { Heating } \\
\text { value } \\
\text { BTU/b }\end{array}$ \\
\hline Wood & 0.87 & 8,420 \\
Paper & 61.87 & 7,709 \\
Polyethylene & 15.60 & 19,949 \\
Cloth & 14.70 & 7,200 \\
Graphite & .15 & 10,000 \\
Rubber & 1.02 & 12,800 \\
Cardboard & .29 & 8,374 \\
Teflon & .09 & 0 \\
Metal & 1.00 & 2,869 \\
Cement & .29 & 0 \\
Sand & 1.06 & 0 \\
PVC plastic & 2.49 & 8,831 \\
Total & 100.00 & \\
\hline
\end{tabular}

- DAW-5, Heterogeneous waste: Heterogeneous waste includes any DAW container that requires special sorting and processing operations. For example, the contents of some containers may include compressed gas cylinders that must be removed to meet safety requirements.

- DAW-6, Special wastes: Special wastes are certain items that have physical, chemical or radiological properties incompatible with the five treatment facilities. Treatment of these items to meet the waste form requirements is outside the scope of the normal process provided for each facility. It is assumed that special waste will be handled by special treatment schemes devised on a case-by-case basis.

- Sludge Waste: Sludge wastes (SLW) are dewatered water treatment filter cakes, ion exchange resins, and other wet solids that have a minimum of $30 \%$ absorbed water content (usually no free water). A further breakdown of this waste is as follows:

- SLW-1, Organic sludge: Organic sludge includes wet sludge and dewatered ionexchange resins and filter-cakes.

- SLW-2, Inorganic sludge: Inorganic sludge includes wet sludge, inert salt cakes, inert filtrate cakes, or ion exchange media. 
- SLW-3, Special waste: Same as special waste discussed above.

- Liquid waste: Liquid waste (LQW) normally has a high concentration of dissolved and suspended solids (assumed to be $20 \%$ for this study) and can be divided according to the following categories:

- LQW-1, Organic liquid: Organic liquid includes low or high boiling point petroleum hydrocarbons, oil, or other volatile organic liquids.

- LQW-2, Inorganic liquid: Inorganic liquid includes evaporator concentrates or concentrated liquids and sludge from filtering off-gas scrubber liquids.

- $\quad$ LQW-3, Special waste: Same as DAW-6. follows:

Additional assumptions regarding the waste radioactivity, hazardous material contents are as

- When wastes are considered mixed waste, the applicable LDR treatment requirements (BDATs) are either solidification, incineration, or vitrification.

- Transuranic waste (TRUW) has a transuranic concentration of greater than $100 \mathrm{nCi} / \mathrm{g}$.

- Alpha-low level waste (LLW) are defense related wastes from Rocky Flats or similar facilities and have a transuranic concentration between 10-100 nCi/g. Alpha-low-level mixed waste (LLMW) is the same as alpha-LLW with the exception that it is controlled under Resource Conservation and Recovery Act (RCRA).

- LLW are nuclear reactor and research related wastes as defined in DOE Order 5280.2A. Defense related LLW have a transuranic concentration of less than $10 \mathrm{nCi} / \mathrm{g}$. LLMW are the same as LLW with the exception that they contain land disposal restrictions (LDR) components and are controlled under RCRA.

- Wastes that contain materials that can jeopardize the safety of processing operations either exist in small quantities and can be safely handled or can be segregated for handling and processing as special material. Waste material in this category includes containers that have free liquids and compressed gas cylinders.

- Remotely handled wastes (e.g., waste containers with gamma radiation surface dose rate above $200 \mathrm{mrem} / \mathrm{h}$ ) are considered special wastes and would not meet the waste acceptance criteria. If such material are contained inside of a shielded container, they will be separated from the routine waste handled at the treatment facilities. These special wastes are treated by special techniques (e.g., shielded portable units) on a case-by-case basis. 


\section{A.3.2 Output Waste Form}

The following assumptions apply to the physical and chemical properties assumed for the output of the treatment plants:

- Waste Form 1-Leach resistant high integrity glass/rock: Produced by vitrification plants, this waste form is a leach-resistant, high-integrity glass-or rock-like material. The waste form also complies with transportation package (TRAMPAC) transuranic transportation packaging criteria. Because of its high quality, this waste form furthermore meets the less stringent requirements for Waste Forms 2 and 3, discussed below.

- Waste Form 2-LDR compliance required: This waste form is produced by the incineration and solidification plants and complies with the LDR requirements. If incineration is used, organics are destroyed and inorganics are fixed in a solidified matrix. If a solidification plant is used, only inorganics are fixed and other methods for destruction of organics, in compliance with LDR, must be used. It is assumed that this waste form will be suitable for a RCRA shallow land disposal facility.

- Waste Form 3-Repackaged Waste: This waste form, which is produced by shredding/compaction plants, consists of repackaged dry active waste. If the waste is LLW, it will be suitable for shallow land disposal. If it is LLMW, alpha-LLW, or alpha-LLMW, it complies with the requirements and acceptance criteria of a deep geological repository, such as Waste Isolation Pilot Plant (WIPP). Waste Form 3 does not meet any of the above waste form requirements and would not meet the LDR requirements.

It is assumed that the output waste from all treatment plants will be packaged in $\mathbf{5 5}$ gal drums with the exception that the shredding/compaction plant output will be packaged in 85 gal drum overpacks.

\section{A.3.3 Facility Design Requirement Assumptions}

\section{A.3.3.1 General Assumptions}

The facility preconceptual designs follow these general assumptions:

- The treatment, storage, and disposal facilities for LLW, LLMW, alpha-LLW and alphaLLMW are classified as a Radioactive Liquid Waste or Radioactive Solid Waste Facility per Section 1323 and 1324 of DOE Order 6430.1A. All buildings that handle radioactive waste are classified as a moderate hazard facility according to University of California Research Laboratories (UCRL) 15910.

- The facilities are designed in accordance with applicable regulations. Specifically, RCRA places design conditions on the storage and treatment process, and performance specifications on the thermal and waste stabilization processes. All equipment has high-quality, low-maintenance features to keep personnel exposure as low as reasonably achievable (ALARA). Remote operations are used to the greatest extent practical. 
- The individual unit operations for treatment and storage facilities are sized to handle at least $125 \%$ of the mass flow rates shown on the process functional diagram.

- Public, employee, and environmental exposures to hazardous and radioactive material will be ALARA.

- The scoping layout of the facilities for each concept is based on the following assumptions:

- Surge capacity for indoor storage of the incoming drums, boxes, bins, and packaged waste is $2-4$ weeks.

- The preconceptual design for processing alpha-LLW/LLMW is based on a conservative assumption that errors in alpha radiation measurement will result in processing waste with higher than $100 \mathrm{nCi} / \mathrm{g}$ transuranic content. Hence, an alpha cell arrangement is used for the layouts.

- Due to the very low concentration of plutonium in alpha-LLW/LLMW, it is assumed that special design for criticality safety will not be required, and facilities will not be subject to health and safety risks associated with criticality.

- Special designs to mitigate health and safety risks associated with pyrophoric and flammable and toxic gas wastes are not provided.

\section{A.3.3.2 Treatment Facility Support Functions}

Support functions included for all treatment facility cost modules include but are not limited to

- Heating, ventilating, and air conditioning (HVAC) nonprocess

- $\quad$ Fire protection

- Electrical (including emergency)

- Process control and data logging

- $\quad$ Radiation instrumentation

- $\quad$ Bulk chemical and additive supply and storage

- Storm water runoff control

- Waste water treatment (hazardous, radioactive, and sanitary).

Input from the site includes utilities, service water, normal and emergency power, and communications. Laboratory and personnel decontamination areas are designed to handle radioactive material. 
Structures housing personnel and nonradioactive components are designed per Uniform Building Code. Laboratory and personnel decontamination areas are designed for handling radioactive material.

\section{A.3.3.3 Common Facility Support Functions}

Support functions for all common facility cost modules include but are not limited to

- Security

- Personnel decontamination (radioactive and hazardous)

- Noncontaminated maintenance

- Health physics

- Sanitary facilities

- Work control/personnel support

- Interior and external (public relations) communications

- Spill or emergency response provisions (hazardous and radioactive)

- Analytical laboratory

- Environmental field sampling

- Environmental regulatory reporting and records management.

Every facility described in this report includes the following interfaces: facility communication, alarm systems including telephone, evacuation, fire, security alarm, and public address systems. All treatment processes are programmed for automatic shut down if the fire system or the evacuation alarm is activated.

\section{A.3.3.4 LLW/LLMW General Assumptions}

Scoping study layouts are shown in EG\&G Idaho internal report, "Waste Management Facility Cost Information Estimating Data," WTD-92-046 (Feizollahi, F. and Shropshire, D., 1992). To facilitate ease of maintenance and reduce employee exposures, each of the main process unit operations are located in a dedicated room. Major components are controlled from a centralized control room. Each facility includes space for support functions such as electrical, HVAC, and mechanical and utility systems. 


\section{A.3.3.5 Alpha-LLW/LLMW General Assumptions}

Scoping study layouts are shown in EG\&G Idaho report, Waste Management Facility Cost Information Estimating Data, WTD-92-046. As with LLW/LLMW, each main process unit operation is located in a dedicated room to facilitate ease of decontamination and maintenance. Process equipment are located in a single alpha cell. Waste enters from one end of the cell and leaves from the opposite end. The front of the cell faces an operating gallery where windows and remote access devices are provided to allow remote operation of the equipment. An equipment pull-out and maintenance gallery is provided in the back end of the cell. Failed components are removed from the cell via air-lock doors and brought to the maintenance gallery for decontamination and maintenance. Each facility includes space for support functions such as electrical, HVAC, mechanical and utility systems.

Properly designed and constructed facilities tailored to each treatment method is considered an effective method for treatment and stabilization, removal of contamination from metals, volume reduction of solid waste, stabilization of liquid and solid LLW/LLMW and alpha-LLW/LLMW, and conversion of noncombustible waste to a high integrity, leach resistant glass/rock-like material.

\section{A.3.4 Facility Operation}

The following assumptions are made for the facility operations:

- Facility operates 24 hours/day, 5 days/week, 240 days/year, and assumes $70 \%$ plant availability during operation. This is equal to 168 days/year, or 4,032 hours/year of operation.

- The operational time span for each facility is 20 years.

\section{A.4 COST BASES AND ASSUMPTIONS}

The following general assumptions are made for the PLCC estimates contained in this report:

- Estimates for new facility construction are based on the conditions for the Idaho National Engineering Laboratory (INEL) site including utility, labor and the related design, construction, operation, and management factors.

- PLCC estimates are developed based on 1992 dollars. The time value of money or escalation for expenditures occurring at different time frames has not been considered in the estimates.

The costs for each facility are divided into these five components: studies and bench scale tests, demonstration, production facility construction, operating and maintenance, and decontamination and decommissioning. Methodology and assumptions used in developing the cost components are given below. 


\section{A.4.1 Planning Studies and Tests}

Estimated planning costs for the planning studies and bench-scale tests for each facility consists of three subcomponents: manpower, equipment testing, and equipment installatir .. Manpower is defined as the effort needed for initial paper studies, bench scale tests, and secondary paper studies. Study durations and nanpower estimates for these efforts were obtained from tables contained in an existing report (F. Feizollahi, et, al., Preliminary Stored Waste Systems Design Study for low-level TRU Waste Treatment Report, EGC-WTD-10254, 1992). Equipment budgetary costs and associated installation costs for lab equipment, such as mixers and prototype ovens used in tests, were obtained from the same reference.

The planning studies and tests cost component was estimated assuming a cost of $\$ 150,000$ per full-time equivalent (FTE) for scientists and engineering manpower.

Table A-2 containing a development, testing, and evaluation cost estimating spreadsheet for a medium-sized incineration facility is included as an example.

\section{A.4.2 Demonstration}

The demonstration cost component consists of nine subcomponents. Cost estimates for three of the subcomponents (manpower during demonstration, building structure, and equiprnent) were obtained from an existing report (Feizollahi, 1992). The remaining six subcomponents (design, inspection, project administration, indirect, construction management, and contingency) were determined by using percentage factors provided by EG\&G Idaho. These factors are the same as those used for the production facility (see Section A.4.3 below), and are as follows:

- Design, inspection, project administration, indirect, construction management, and contingency costs subcomponents are developed using percentage guidelines. This approack facilitates development of PLCC estimates suitable for relative comparison of various options. The percentages are historical averages experienced by DOE contractors at the INEL for the types of activities covered by waste management facilities. In addition,

- Contingency on all costs is $25 \%$.

- Design cost, applied to construction cost total, is $30 \%$ during the demonstration phase. During the production phase, it is $18 \%$ for LLW/LLMW and $25 \%$ for alphaLLW/LLMW facilities. Design costs for the storage and disposal facilities are $18 \%$ of the cost for 1 year's capacity of storage or disposal structures.

- Inspectiun cost, applied to construction cost total, is $7 \%$.

- Project management cost, applied to construction cost total, is $10 \%$.

- Indirect cost, applied to total building plus equipment and installation costs, is $29 \%$. 
Table A-2. Development, testing, and evaluation cost estimates for incineration facility.

\begin{tabular}{|c|c|c|c|c|c|c|c|c|c|c|c|}
\hline \multirow{2}{*}{\multicolumn{2}{|c|}{ ALPHA }} & \multirow{2}{*}{\multicolumn{10}{|c|}{ MaEDNM }} \\
\hline & & & & & & & & & & & \\
\hline \multicolumn{2}{|r|}{ UNTT OPERATTON } & $\begin{array}{c}\text { Primany } \\
\text { Paper } \\
\text { Elaluation } \\
\text { Research } \\
\text { Manpower }\end{array}$ & $\begin{array}{c}\text { Bench } \\
\text { Scale } \\
\text { Studies } \\
\text { Resenrch } \\
\text { Manpower }\end{array}$ & $\begin{array}{cc}\text { Sec. } \\
\text { Paper } \\
\text { Evaluation } \\
\text { Research } \\
\text { Manpower }\end{array}$ & $\begin{array}{c}\text { Tolal } \\
\text { Research } \\
\text { Manpower }\end{array}$ & $\begin{array}{l}\text { Bench } \\
\text { Scale } \\
\text { Studies } \\
\text { Equipment } \\
\text { s1000 }\end{array}$ & 1 & $\begin{array}{l}\text { Bench } \\
\text { Scale } \\
\text { Studies } \\
\text { stallation } \\
\text { Sino0 }\end{array}$ & $\begin{array}{c}\text { Pilot } \\
\text { Plant } \\
\text { Mock-up } \\
\text { Test Demo. } \\
\text { Manpouer }\end{array}$ & $\begin{array}{c}\text { Pilot } \\
\text { Plant } \\
\text { Mock-up } \\
\text { Test Bldg. } \\
\text { siom }\end{array}$ & $\begin{array}{c}\text { Pilot } \\
\text { Plant } \\
\text { Mock-up } \\
\text { Test Equip. } \\
\text { \$1000 }\end{array}$ \\
\hline $\mathrm{DA}-1$ & Prepare \& Feed Incoming Waste & & $1 \cdot$ & $!$ & 11 & & $\vdots$ & & $3:$ & 50 & 100 \\
\hline DA-2 & Incinerator & & 2 & $i$ & $2 !$ & & & & 10. & 100 & 500 \\
\hline $\mathrm{DA}-3$ & Prepare \& Feed ior Solidifiation & & & & $\vdots$ & & 1 & & & & \\
\hline $\mathrm{DA}-4$ & Soliditi & & $\overline{11}$ & 31 & $6 !$ & & 01 & 1.50 & & & \\
\hline DA-5 & Drum Capping \& Washing & -1 & & $\div$ & 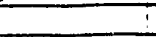 & 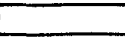 & 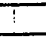 & & & & \\
\hline DA-6 & OOH-Gas Treatment & i & 2 & 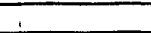 & 21 & & & & 3. & 20: & 1.50 \\
\hline $\mathrm{DA}-7$ & I Prepare \& ieed Lime & - & & $\vdots$ & & & 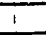 & & & & \\
\hline $\mathrm{DA}-8$ & :Treas Liquid Waste & & & . & & & $\therefore$ & & & & \\
\hline DA-9 & i Store \& Feed Binder & 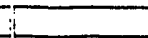 & & $!$ & & & & & & & \\
\hline$D A-10$ & Elec. Dist \& MC.C. & - & & & $i$ & 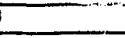 & & & & & \\
\hline $\mathrm{DA}-11$ & : Heating Ventilation \& Exhaust & ii & & 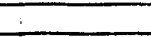 & & & $\therefore$ & & & 1 & \\
\hline \multirow[t]{4}{*}{ DA-12 } & Other Equipment & it & & & & & & & & & \\
\hline & Unit (Cost (s; Unit) & & & & $\$ 1.50 .000$ & & & & $\$ 1.50 .000$ & & \\
\hline & Total Cost & & & & $1,6.50 !$ & & 0 & 150 & $\therefore 400$ & 1801 & 7.50 \\
\hline & & Post Torais to & 10 Table DA-6 & $6.11 \mathrm{em}$ & & 1.2 & & 1,3 & 3.1 & 211 & 3.9 .1 \\
\hline
\end{tabular}

TABLE DL-2 : Development, Testing \& Evaloa rion Cost Sstimates - INCINERATION

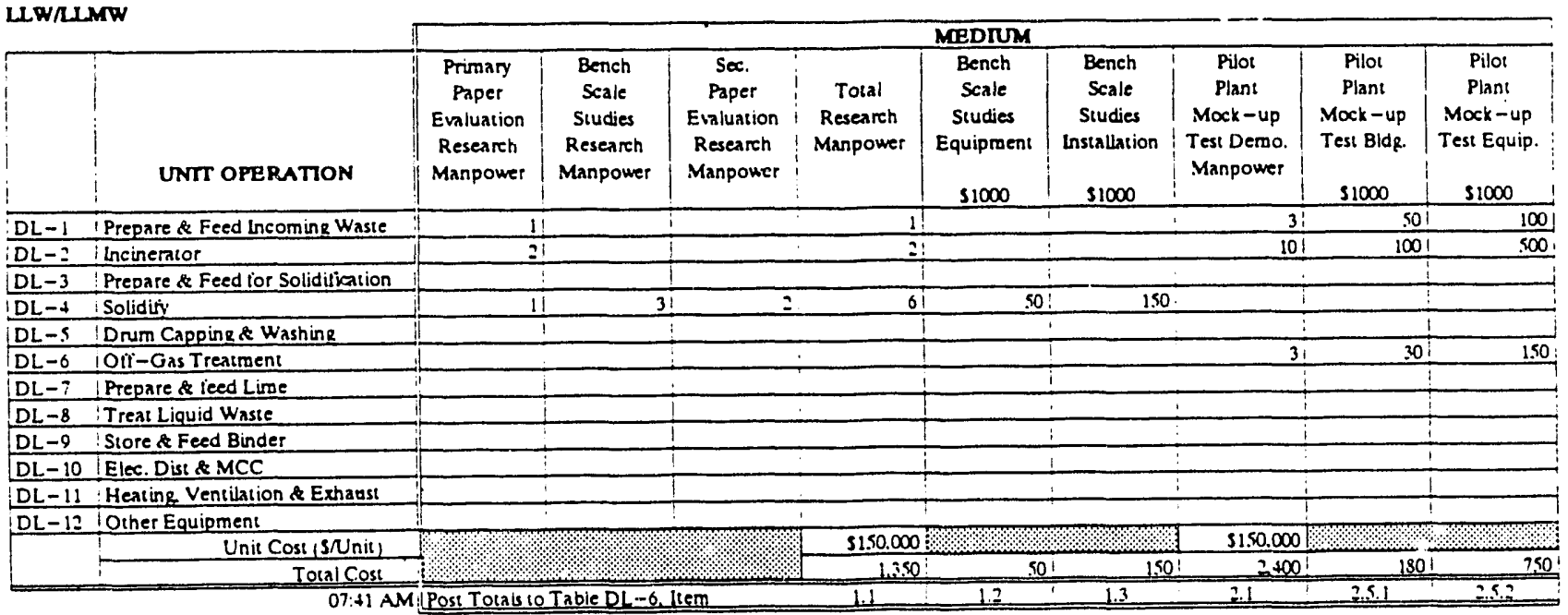


- Construction management (CM) costs applied only to production construction costs total, are $17.1 \%$.

- Construction management reserve is $10 \%$.

Major assumptions used for developing the budgetary cost estimates for the demonstration cost component are given below.

- The demonstration equipment cost estimates are budgetary and based on industrial equipment, which costs less than the final equipment that will be provided for the production facility. Accordingly, it is assumed that material used in test assemblies will be fabricated from commonly available industrial equipment.

- In the vitrification system, the demonstration melter train (i.e., melter, off-gas treatment, and slag cooling/packaging) will be tested in an existing building as a single assembly.

- In the open, dump, and sort facilities, remotely operated devices needed for container opening, dumping, sorting, crushing, and shredding will be demonstrated in a simulated cell environment as an integrated single assembly.

- Incineration demonstration including its off-gas will be carried out in a contract pilot-plant and will be assembled in an existing building.

- All other demonstrations, such as liquid waste treatment, alpha assay instruments, and decontamination, will be performed by vendors. An example of the demonstration cost spreadsheet is shown in Table A-2.

\section{A.4.3 Production Facility Construction}

The production facility cost consists of nine subcomponents. Two of the subcomponents, equipment and installation, are estimated in this report and included in the cost model tables. The costs are based on an equipment list developed from the information provided in the F\&ORs and process functional diagrams. Then, equipment budgetary purchase costs are estimated using either vendor budgetary quotations, historical cost information, or engineering judgements. Installation costs are estimated for each piece of equipment and include labor, construction equipment, small tools, and supplies. Whenever vendor quotes were based on off-the-shelf equipment, they were multiplied by an appropriate adjustment factor to allow for NQA-1 and other more complex requirements of the specific process. Table A-3 containing equipment purchase and installation costs for a medium-sized incineration facility is included as an example.

A third subcomponent, building cost, is developed by multiplying the estimated building space required for each unit operation by a set of unit rates provided by EG\&G Idaho and Morrison Knudsen Corporation (MK). The allocated building space estimates are developed from the scoping study layout sketches presented in the attachments. The estimates include allocated space in separate categories to account for different hazard levels. The estimated square footage and the calculated building cost estimates for each unit operation are listed in the cost model tables. Table A-4 
Table A-3. Equipment purchase and installation budgetary cost estimate for incineration facility.

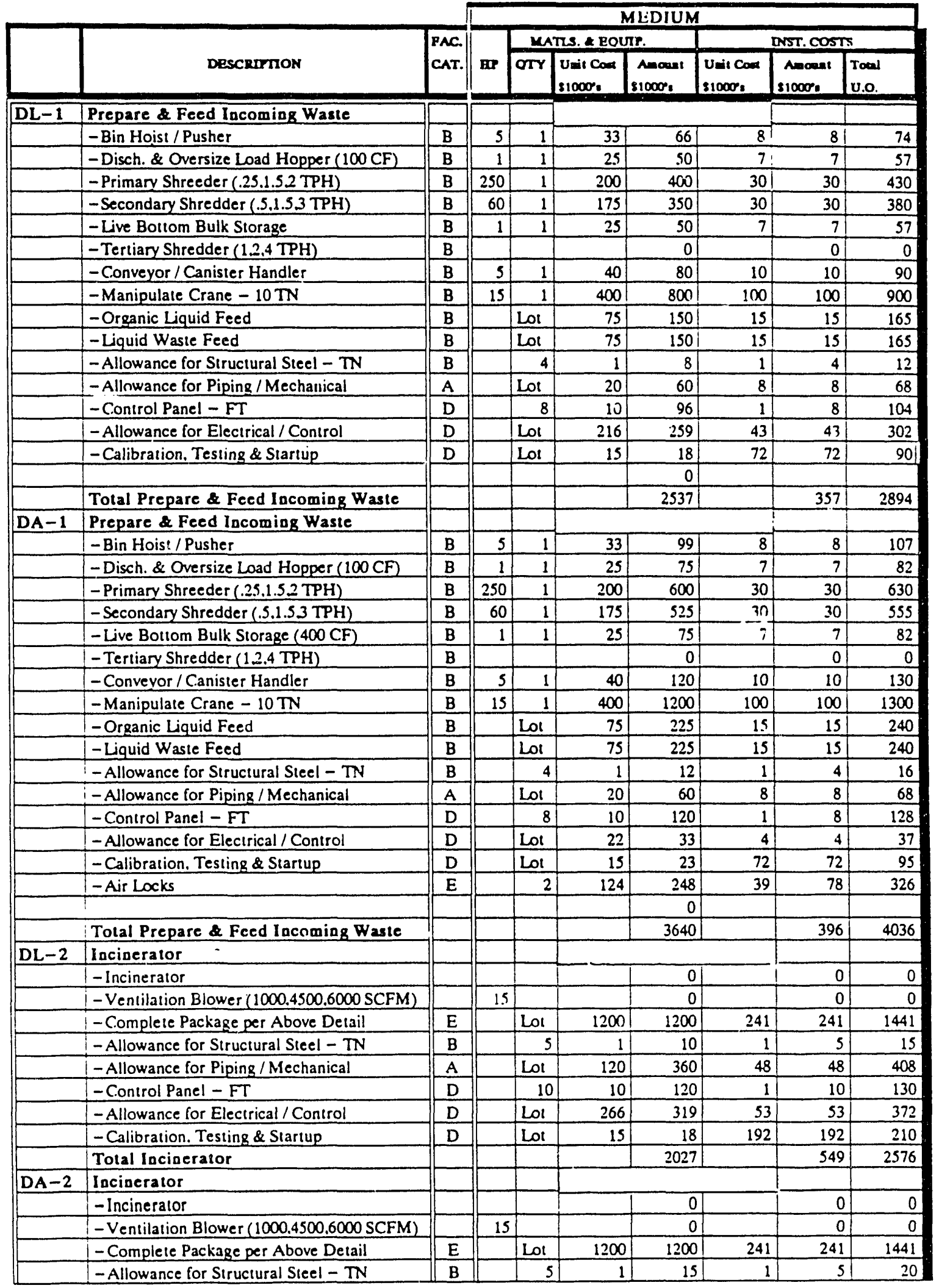


Table A-3. (continued).

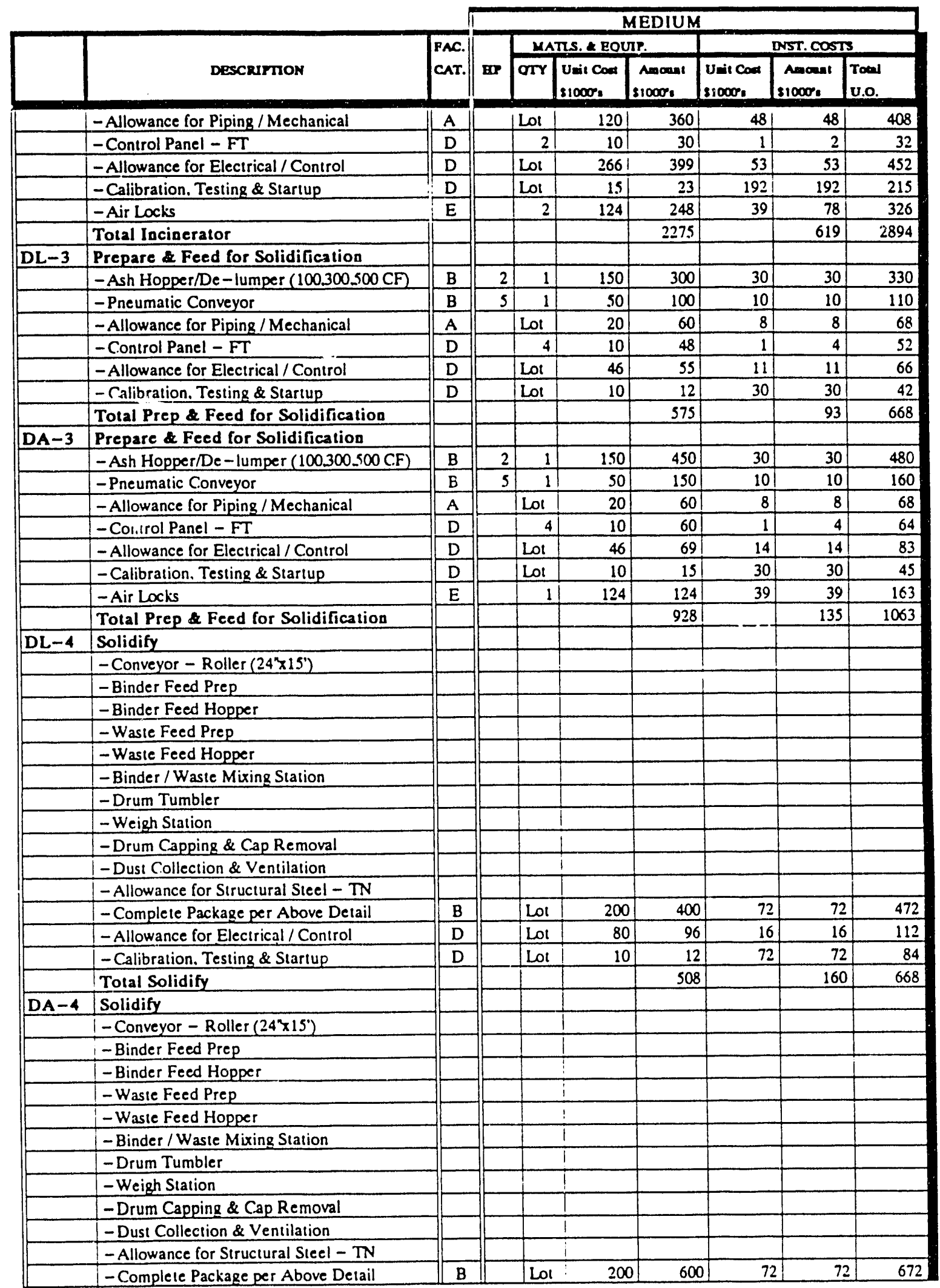


Table A-3. (continued).

\begin{tabular}{|c|c|c|c|c|c|c|c|c|c|}
\hline & & 1 & \multicolumn{7}{|c|}{ MEDIUM } \\
\hline & \multirow[b]{2}{*}{ DESCRITION } & \multirow{2}{*}{ PAC. } & \multirow[b]{2}{*}{$\mathbf{u x}$} & \multicolumn{3}{|c|}{ MATS \& EOUTr. } & \multicolumn{3}{|c|}{ DNST. costs } \\
\hline & & & & orr & $\begin{array}{l}\text { Umit cons } \\
\text { s1000\%s }\end{array}$ & $\begin{array}{l}\text { Anowat } \\
\text { sionos: }\end{array}$ & $\begin{array}{l}\text { Unit con } \\
\text { S1000\%: }\end{array}$ & Amount & $\begin{array}{l}\text { Toal } \\
\text { U.o. }\end{array}$ \\
\hline & - Allowance for Electrical / Control & D & & LOI & $80 !$ & 120 & 16 & $16 !$ & 136 \\
\hline & - Calibration. Testing \& Startup & $\mathrm{D}$ & & Lot & 10 & 15 & 72 & 72 & 87 \\
\hline & - Air Locks & $E$ & & 1 & 124 & 124 & 39 & 39 & 163 \\
\hline & Total Solidify & & & & & 859 & & 199 & 1058 \\
\hline \multirow[t]{7}{*}{ DL -5} & Drum Capping \& Washing & 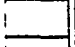 & & & & & & & \\
\hline & -Drum Wash Unit & $A$ & & 2 & 25 & 150 & 5 & 10 & 160 \\
\hline & -Drum Conveying System & B & & 2 & 10 & 40 & 2 & 4 & 44 \\
\hline & - Control Panel - FT & D & & 2 & 101 & 24 & 1 & 2 & 26 \\
\hline & - Allowance for Electrical / Control & D & & Lot & 9 & 11 & 2 & $2]$ & 13 \\
\hline & - Caiibration. Testine \& Startup & D & & Lot & 2 & 2. & 42 & 42 & 44 \\
\hline & Total Drum Capping \& Washing & & & & & 227 & & 60 & 287 \\
\hline \multirow[t]{8}{*}{ DA-5 } & Drum Capping \& Washing & & & & & & & & \\
\hline & - Drum Wash Unit & A & & 2 & 25 & 150 & 5 & 10 & 160 \\
\hline & - Drum Conveying System & B & & 2 & 10 & 60 & 2 & 4 & 64 \\
\hline & - Control Panel & D & & 2 & 10 & 30 & 1 & 2 & 32 \\
\hline & - Allowance for Electrical / Control & D & & Lot & 9 & 14 & 2 & 2 & 16 \\
\hline & - Calibration, Testing \& Startup & D & & Lol & 2 & 3 & 42 & 42 & 45 \\
\hline & - Air Locks & $E$ & & 2 & 121 & 248 & 39 & 78 & 326 \\
\hline & Total Drum Capping \& Washing & & & & & 505 & & 138 & 643 \\
\hline & & & & & & & & & \\
\hline \multirow[t]{21}{*}{ DL-6 } & Off-Gas Treatmeal & & & & & & & & \\
\hline & - Gas Cooler & & & & & & & & \\
\hline & - Wet Scrubber & & & & & & & & \\
\hline & - Quenching Tower & & & & & & & & \\
\hline & - Mist Eliminator & & & & & & & & \\
\hline & - Heat Exchanger & & & & & & & & \\
\hline & - Condensor & & & & & & & & \\
\hline & -Scrubber Liquid Collection Tank & & & & & & & & \\
\hline & - Rehealer & & & & & & & & \\
\hline & - HEPA Filter & & & & & & & & \\
\hline & - Glycol Cooling System & & & & & & & & \\
\hline & - Main Off-Gas Blower & it & & & & & & & \\
\hline & - Exhaust Stack & & & & & & & & \\
\hline & - Complete Package per Above Detail & E. & & Lot & 1620 & 1620 & 324 & 324 & 1944 \\
\hline & -De-Nox Unit & $E$ & & Lot & 200 & 200 & 20 & 20 & 220 \\
\hline & -Environmental / Rad. Monitoring & $E$ & & Lol & 600 & 600 & 120 & 120 & 720 \\
\hline & - Allowance for Valves. Pumps \& Piping & A & & Lol & 242 & 726 & 97 & 97 & 823 \\
\hline & - Control Panel - FT & D & & 8 & 10 & 96 & 1 & 8 & 104 \\
\hline & - Allowance for Electrical / Control & $\mathrm{D}$ & & Lot & 534 & 641 & 107 & 107 & 748 \\
\hline & - Calibration. Testing \& Startup & D & & Lot & 15 & 18 & 224 & 224 & 242 \\
\hline & Total Off-Gas Treatmeat & & & & & 3901 & & 900 & 4801 \\
\hline \multirow[t]{11}{*}{ DA -6 } & Off-Gas Treatment & 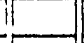 & & & & & & & \\
\hline & - Gas Cooler & I & & & & & & & \\
\hline & - Wet Scrubber & 2 & & & & & & & \\
\hline & - Quenching Tower & & & & & & & & \\
\hline & - Mist Eliminator & & & & & & & & \\
\hline & - Heat Exchanger & & & & & & & & \\
\hline & - Condenser & 1 & & & & & & & \\
\hline & - Scrubber Liquid Collection Tank & & & & & & & & \\
\hline & - Rehealer & & & & & & & & \\
\hline & - HEPA Filier & & & & & & & & \\
\hline & - Glycol Cooling System & 1 & & & & & & & \\
\hline
\end{tabular}


Table A-3. (continued).

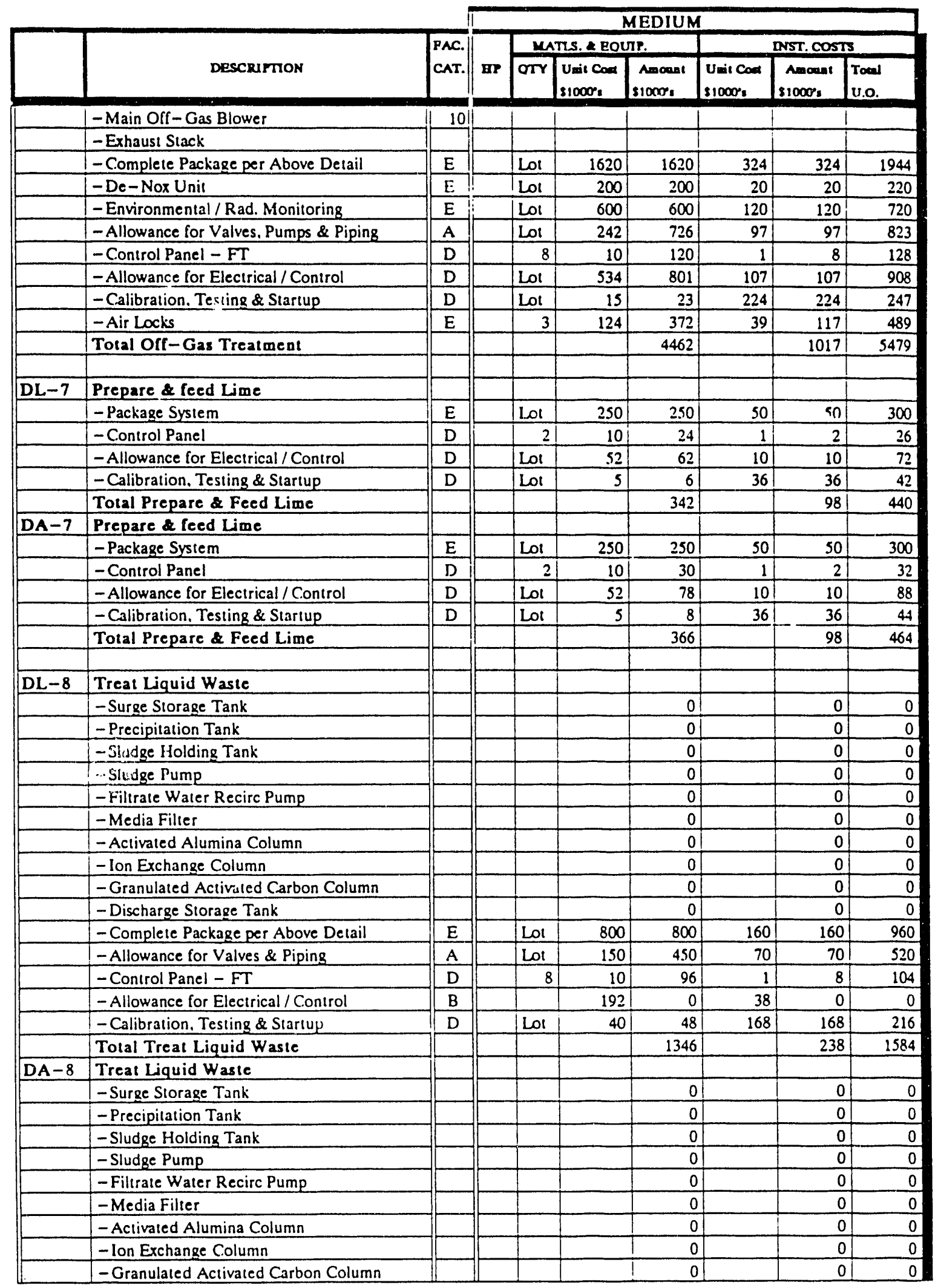


Table A-3. (continued).

\begin{tabular}{|c|c|c|c|c|c|c|c|c|c|}
\hline & & & \multicolumn{7}{|c|}{ MEDIUM } \\
\hline & \multirow[b]{2}{*}{ Descention } & \multirow{2}{*}{$\begin{array}{l}\text { PAC. } \\
\text { CAT. }\end{array}$} & \multirow[b]{2}{*}{$\mathbf{m}$} & \multicolumn{3}{|c|}{ MATSS. EQUTI. } & \multicolumn{3}{|c|}{ DNST. costs } \\
\hline & & & & orr & $\begin{array}{l}\text { Udit cont } \\
\text { stoopos: }\end{array}$ & $\begin{array}{l}\text { Amonss } \\
\text { s10000, }\end{array}$ & $\begin{array}{l}\text { Umil cont } \\
81000 \text { a }\end{array}$ & $\begin{array}{l}\text { Amonet } \\
\text { s10000 }\end{array}$ & $\begin{array}{l}\text { Toend } \\
\text { u.o. }\end{array}$ \\
\hline & - Discharge Storage Tank & & & & & 0 & & 0 & 0 \\
\hline & - Comp'ete Package per Above Detail & $E$ & & Lot & 800 & 800 & 160 & 160 & 960 \\
\hline & - Allowance for Valves \& Piping & A & & Lol & 150 & 450 & 70 & 70 & 520 \\
\hline & - Control Panel - FT & D & & 8 & 10 & 120 & 1 & 8 & 128 \\
\hline & - Allowance for Electrical / Control & D & & Lot & 192 & 288 & 38 & 38 & 326 \\
\hline & - Calibration, Testing \& Startup & D & & Lot & 40 & 60 & 63 & 63 & 123 \\
\hline & Total Treat Liquid Waste & & & & & 1718 & & 339 & 2057 \\
\hline & & & & & & & & & \\
\hline \multirow[t]{6}{*}{$\mathrm{DL}-9$} & Store \& Feed Binder & & & & & & & & \\
\hline & - Package System & $E$ & & Lot & 250 & 250 & 50 & 50 & 300 \\
\hline & - Control Panel - FT & $\mathrm{D}$ & & 2 & 10 & 24 & 1 & 2 & 26 \\
\hline & - Allowance for Electrical / Control & $\mathrm{D}$ & & Lol & 52 & 62 & 10 & 10 & 72 \\
\hline & - Calibration. Testing \& Startli? & $\mathrm{D}$ & & Lot & 5 & 6 & 36 & 36 & 42 \\
\hline & Total Store \& Feed Binder & & & & & 342 & & 98 & 440 \\
\hline \multirow[t]{6}{*}{ DA-9 } & Slore \& Feed Binder & & & & & & & & \\
\hline & - Package System & $\mathrm{E}$ & & Lot & 250 & 250 & 50 & 50 & 300 \\
\hline & - Control Panel - FT & D & & 2 & 10 & 30 & 1 & 2 & 32 \\
\hline & - Allowance for Electrical / Control & D & & Lol & 52 & 78 & 10 & 10 & 88 \\
\hline & - Calibration. Testing \& Startup & D & & Lot & 5 & 8 & 36 & 36 & 44 \\
\hline & Total Store a Feed Binder & & & & & 366 & & 98 & 464 \\
\hline $\mathrm{DL}-10$ & Elec. Dist \& MCC & & & & & & & & \\
\hline$D A-10$ & Elec. Dist \& MCC & & & & & & & & \\
\hline $\mathrm{DL}-11$ & Heating, Ventilation \& Exhaust & & & & & & & & \\
\hline DA-11 & Heating, Ventilation \& Exhaust & & & & & & & & \\
\hline \multirow[t]{11}{*}{$D L-12$} & Other Equipment & & & & & & & & \\
\hline & - Fire Suppression System (Shredder Area) & $E$ & & Lot & 70 & 70 & 15 & 15 & 85 \\
\hline & - Radiation Monitoring System & $E$ & & Lol & 350 & 350 & 60 & 60 & 410 \\
\hline & - Fire Suppression System (Other Area) & 1 & & Lol & 65 & 65 & 12 & 12 & 77 \\
\hline & - Eniergencey Shower \& Decon Station & $\ddot{E}$ & & Lot & 30 & 30 & 6 & 6 & 36 \\
\hline & - Sump Pump & $A$ & & Lot & 10 & 30 & 3 & 3 & 33 \\
\hline & - Service \& Instrument Air & $E$ & & Lot & 190 & 190 & 50 & 50 & 240 \\
\hline & - Stand By Emergency Power System & D & & Lot & 230 & 276 & 40 & 40 & 316 \\
\hline & - & & & & & 0 & & & \\
\hline & - & & & & & 0 & & & \\
\hline & Total Other Equipment & & & & & 1011 & & 186 & 1197 \\
\hline \multirow[t]{9}{*}{$\mathrm{DA}-12$} & Other Equipment & & & & & & & & \\
\hline & - Fire Suppression System (Shredder Area) & $E$ & & Lo! & 70 & 70 & 15 & 15 & 85 \\
\hline & - Radiation Monitoring System & $E$ & & Lol & 700 & 700 & 60 & 60 & 760 \\
\hline & - Fire Suppression System (Other Area) & $E$ & & Lot & 65 & 65 & 12 & 12 & 77 \\
\hline & - Emer: ncey Shower \& Decon Station & $E$ & & Lol & 30 & 30 & 6 & 6 & 36 \\
\hline & - Sump Pump & A & & Lot & 10 & 30 & 3 & 3. & 33 \\
\hline & - Service \& Instrumenl Air & $E$ & & Lot & 190 & 190 & 50 & 50 & 240 \\
\hline & -Stand By Emergency Power System & $D$ & & Lot & 230 & 345 & 40 & 40 & 385 \\
\hline & Tolal Olber Equipmenl & & & & & 1430 & & 186 & 1616 \\
\hline
\end{tabular}


Table A-4. Building and equipment material and installation cost estimate summary for incineration facility.

Estimate Summary - INCINERATION - ALPHA

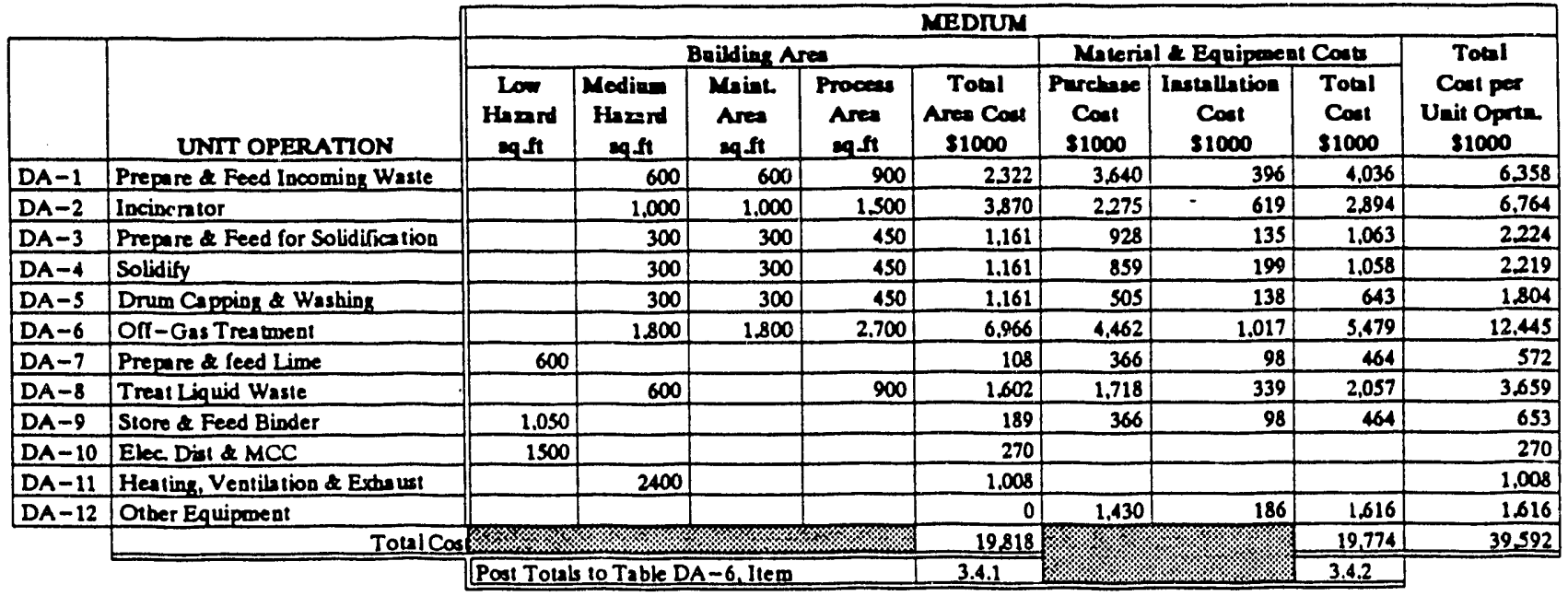

Estimate Summary - INCINERATION

\begin{tabular}{|c|c|c|c|c|c|c|c|c|c|c|}
\hline & \multirow[b]{3}{*}{ UNTT OPERATION } & \multicolumn{9}{|c|}{ MEDIUM } \\
\hline & & \multicolumn{5}{|c|}{ Building Are } & \multicolumn{3}{|c|}{ Material \& Equiponent Coats } & \multirow{2}{*}{$\begin{array}{c}\text { Total } \\
\text { Cost per } \\
\text { Unit Oprte. } \\
\$ 1000\end{array}$} \\
\hline & & $\begin{array}{l}\text { Low } \\
\text { Hamed } \\
\text { egft }\end{array}$ & $\begin{array}{l}\text { Meding } \\
\text { Hemnd } \\
\text { eqf }\end{array}$ & $\begin{array}{l}\text { Maint } \\
\text { Are } \\
\text { osft }\end{array}$ & $\begin{array}{l}\text { Process } \\
\text { Area } \\
\text { eqfit }\end{array}$ & $\begin{array}{c}\text { Total } \\
\text { Ares Cout } \\
\text { S1000 }\end{array}$ & $\begin{array}{c}\text { Purchese } \\
\text { Cost } \\
\$ 1000\end{array}$ & $\begin{array}{c}\text { Instalintion } \\
\text { Cost } \\
\text { s1000 }\end{array}$ & $\begin{array}{l}\text { Total } \\
\text { Cost } \\
\$ 1000\end{array}$ & \\
\hline $\mathrm{DL}-1$ & Prepare \& Feed Incoming Waste & & 1200 & & & 504 & 2537 & 357 & 2.894 & 3.398 \\
\hline $\mathrm{DL}-2$ & Incinerator & & 2.000 & & & 840 & 2.027 & 549 & 2576 & 3.416 \\
\hline $\mathrm{DL}-3$ & Prepare \& Feed for Solidification & & 600 & & & 252 & 575 & 93. & 668 & 920 \\
\hline $\mathrm{DL}-5$ & Drum Capping \& Washing & & 600 & & & 252 & 227 & 60 & 287 & 539 \\
\hline $\mathrm{DL}-6$ & Off-Gas Treatment & & 3.600 & & & 1.512 & 3.901 & 900 & 4801 & 6.313 \\
\hline $\mathrm{DL}-7$ & Prepare \& feed Lime & 400 & & & & 72. & 342 & 98 & 40 & 512 \\
\hline $\mathrm{DL}-8$ & Treal Liquid Wasle & & 1.200 & & & 504 & 1346 & 238 & 1584 & 2.088 \\
\hline $\mathrm{DL}-9$ & Store \& Feed Binder & 400 & & & & 72 & 342 & 98 & 440 & 512 \\
\hline $\mathrm{DL}-10$ & Elec. Dist \& MCC & 16.50 & & & & 297 & & & & 297 \\
\hline$D L-11$ & Heating, Ventilation \& Exhaust & & 1600 & & & 672 & & & & 672 \\
\hline \multirow[t]{3}{*}{$\mathrm{DL}-12$} & Other Equipment & & & & & 0 & 1.011 & 186 & 1.197 & 1.197 \\
\hline & Total Cost & \multirow{2}{*}{\multicolumn{4}{|c|}{ Post Tolals to Table DL- 6 , liem }} & 5,229 & & & 15,555 & 20.784 \\
\hline & & & & & & 3.4 .1 & & & 3.4 .2 & \\
\hline
\end{tabular}


containing building and equipment material and installation estimate cost summary for an incineration facility is included as an example.

The building unit rates costs are representative of the building and its support systems, including utilities, fire protection, and site development costs. The alpha cell space building costs include highefficiency particulate air (HEPA) filter systems. Special equipment and any additional mechanical or electrical systems necessary for operation of the equipment have not been included in the building unit rate costs. The unit rates do not include the construction contractor direct and indirect costs and the appropriate overheads and profit.

The remaining six cost subcomponents (design, inspection, project administration, indirect, construction management, and contingency) are determined using percentage factors. These percentages, building unit rates, and other major assumptions used to develop the production facility construction costs are the same as listed in Section A.4.2, above.

- The building unit rate costs listed below are for treatment facilities and based on similar facilities at the INEL.

- Low hazards areas (e.g., areas for support and nonprocess functions including office, and incoming and outgoing packaged waste storage and handling spaces) are $\$ 180 / \mathrm{ft}^{2}$.

- Moderate hazard building space including areas used for LLW/LLMW waste processing and alpha-LLW/LLMW operating galleries is $\$ 420 / \mathrm{ft}^{2}$.

- Alpha cell space with double confinement barrier used for alpha-LLW/LLMW equipment maintenance galleries is $\$ 1200 / \mathrm{ft}^{2}$.

- Alpha cell space with triple confinement barriers used to house alpha-LLW/LLMW processing equipment is $\$ 1,500 / \mathrm{ft}^{2}$.

- Building costs for storage facilities are based on similar preconceptual facility designs by MK. The following costs apply:

- Loading/unloading and office areas at the front-end/back-end facility are $\$ 180 / \mathrm{ft}^{2}$.

- The lab area for the front-end/back-end support facility are $\$ 420 / \mathrm{ft}^{2}$.

- Small, medium, and large storage warehouses are $\$ 73 / \mathrm{ft}^{2}, \$ 57 / \mathrm{ft}^{2}$, and $\$ 47 / \mathrm{ft}^{2}$, respectively.

- Building costs for disposal facilities are based similar facilities at the Illinois LLW site. The hazard categories and their associated costs are as follows:

- Low Hazard I space for administration/offices, warehouse and maintenance, material storage for the grout plant, unload/staging area, storage building, canister storage at the waste packaging building, utilities/mechanical building, and electrical substation. The cost is $\$ 165 / \mathrm{ft}^{2}$. 
- Low Hazard II space for the site access building and truck wash station, as well as the lab, is $\$ 231 / \mathrm{ft}^{2}$.

- Medium Hazard building space, which includes the waste packaging area, grout plant, assay, inspection, certification, secondary treatment, and waste packaging, is estimated at $\$ 346 / \mathrm{ft}^{2}$.

- Stainless steel equipment is selected to allow for easy decontamination and maintenance. Stainless steel is specified even when materials considerations indicated that cheaper construction would be appropriate. Therefore, the estimate assumes the most expensive equipment or factors.

- The process areas for alpha-LLW/LLMW are located in an alpha cell with triple confinement barriers.

- Maintenance areas for alpha-LLW/LLMW are located in an alpha cell with double confinement barriers.

- Process and maintenance areas for LLW and LLMW process equipment are located in a moderate hazard rated building with approximately 12 in. of concrete walls for shielding.

- Facility construction cost estimates in this report do not include the infrastructure (utilities, roads or site development).

\section{A.4.4 Operation and Maintenance}

Operation and maintenance (O\&M) cost is comprised of four subcomponents: operating manpower, utilities, materials, and maintenance. Operating manpower is estimated for each unit operation by assuming an appropriate operating crew for that unit. The estimated operating FTE requirements for each unit operation is presented in cost model tables in the attachments. PLCC estimates for the utility cost subcomponents, summarized in the cost model tables, include electric power, natural gas or No. 2 fuel oil, as appropriate. These costs are estimated by multiplying the equipment horsepower and energy consumption rates for each facility by the given energy cost unit rates (see below).

The material cost subcomponents includes consumables such as shipping/disposal containers, additives, chemicals, and personnel protective equipment. These are estimated for each facility based on the process flow rates given in the preconceptual design packages and are listed in the tables included in the cost model.

The maintenance cost subcomponent is divided into maintenance labor and maintenance replacement equipment cost. These costs, presented in the tables in the cost model, are obtained by assuming that the annual maintenance equipment cost is $7 \%$ of the original equipment capital cost and that the annual maintenance labor cost is $250 \%$ of the maintenance equipment cost. 
General assumptions used to develop the operation and maintenance costs are given below:

- The following utility and operating rates are established based on INEL site for the development of life cycle costs:

- Electricity @ \$0.035/kWh

- Propane @ \$0.60/gal

- No. 2 fuel oil @ \$0.80 per gal.

- Present day costs are used for preparation of the O\&M cost estimates.

- A contingency factor of $25 \%$ is applied to the project subtotal O\&M costs.

- Operating staff labor rate is $\$ 140,000 /$ FTE.

- Unprocessed waste is packaged in drums, boxes, or metal bins at the originating facility before shipment to the treatment plants. Hence, cost for packaging of unprocessed waste is not included in the estimates.

- Additive soil cost for the vitrification facility is negligible.

- The O\&M costs are based on a facility operating schedule of three 8-hour shifts, 5 days/week, and 240 days/year.

- Portland cement binder cost for solidification is $\$ 0.05 / \mathrm{b}$.

- Shipping/disposal container is $55 \mathrm{gal}$ drums at $\$ 25 /$ each or 85 gal drums at $\$ 40 /$ each.

\section{A.4.5 Operating Budget Funded Activities}

In accordance with DOE orders, there are a number of activities that can not be charged to the Line Item Construction Projects funds. A breakdown of these activities and preliminary cost estimates are given below. It is assumed that the level of effort required for some of these activities are the same for all major facilities, except common support facilities.

Project activities to be funded by operating budgets and the estimated costs are

- Conceptual design at $1.5 \%$ of construction cost.

- Project management prior to Title I design at $10 \%$ of the National Environmental Policy Act (NEPA) conceptual design safety assurance and preparation for operation costs.

- Environmental and permitting (NEPA documentation including environmental impact statements, Federal, state, and local permits) estimated at $\$ 6,000,000$ for each waste treatment and disposal facility that requires a full NEPA process including preparation, 
review and approval of an environmental impact statement. Smaller projects such as shredding/compaction and storage facilities are assumed to require only an environmental assessment report followed by a finding of no significant impact and are estimated at $\$ 1,000,000$. Since front-end and back-end support facilities are assumed to be constructed along with the main facilities, no permitting/NEPA cost allowances are required.

- Safety assurance documentation (safety analysis, reliability, availability and maintainability analysis, probabilistic risk assessment, hazards analysis, criticality reviews, and radiation analysis) at $1.5 \%$ of the construction cost.

- Preparation for operation (operations procedure, operating personnel staffing, training and testing, readiness reviews, spare parts, and material) is assumed to start 3 years before the facility begins production operation. Based on the experience at the TSCA incinerator at Oak Ridge National Laboratory, the cost for the preoperation activity is assumed to be approximately $100 \%$ of the annual operating cost. This accounts for $15 \%$ for the first year of preoperation, $25 \%$ in the second year, and $60 \%$ in the last year.

\section{A.4.6 Decommissioning}

Decontamination and decommissioning costs for treatment facilities are based on a recent cost study conducted by EG\&G Idaho for the buried transuranic waste (R. Schlueter, et al., Low-Level and Transuranic Waste Transportation Disposal and Facility Decommissioning Cost Sensitivity Analysis, WTD-10092, 1992). Based on this study, a cost of $\$ 450 / \mathrm{ft}^{3}$ average unit rate for treatment facilities is used. Decontamination and decommissioning costs for storage facilities are estimated at $\$ 50 / \mathrm{ft}^{2}$. The calculated costs are shown in the cost model tables. Table A-5 containing decontamination and decommissioning costs for an incineration facility is included as an example.

\section{A.4.7 Transportation Costs}

Transportation costs are based on a recent cost study conducted by EG\&G Idaho for the buried transuranic waste (Schlueter, 1992). Transportation costs are calculated based on the system input or output waste volumes, whichever is appropriate.

\section{A.4.8 Cost Summaries}

Cost summaries are presented according to the six components described in this appendix. Also shown in cost summary tables are cost subcomponents and the appropriate multiplication factors. These tables have been included in Sections 2 through 17 of main report. 
Table A-5. Decontamination and decommissioning cost estimates for an incineration facility.

\begin{tabular}{|c|c|c|c|c|c|c|}
\hline \multicolumn{2}{|r|}{$A L P H A$} & \multicolumn{5}{|c|}{ MEDIUM } \\
\hline & \multirow[b]{2}{*}{ UNIT OPERATION } & \multicolumn{5}{|c|}{ Building Area } \\
\hline & & $\begin{array}{c}\text { Low } \\
\text { Hazard } \\
\text { sq.ft }\end{array}$ & $\begin{array}{c}\text { Medium } \\
\text { Hazard } \\
\text { sq.ft }\end{array}$ & $\begin{array}{c}\text { Maint. } \\
\text { Area } \\
\cdot \\
\text { sq.ft }\end{array}$ & $\begin{array}{c}\text { Process } \\
\text { Area } \\
\text { sq.ft } \\
\end{array}$ & $\begin{array}{l}\text { D\&D Cost } \\
(X \$ 1000)\end{array}$ \\
\hline $\mathrm{DA}-1$ & Prepare \& Feed Incoming Waste & 0 & 600 & 600 & 900 & 945 \\
\hline $\mathrm{DA}-2$ & Incinerator & 01 & 1000 & 1000 & $1500 !$ & 1.575 \\
\hline $\mathrm{DA}-3$ & Prepare \& Feed for Solidification & $0 \mid$ & 300 & 300 & $450 !$ & 473 \\
\hline $\mathrm{DA}-4$ & Solidify & 0 & 300 & 300 & 4501 & 473 \\
\hline $\mathrm{DA}-5$ & Drum Capping \& Washing & 0 & 300 & 300 & 4501 & 473 \\
\hline $\mathrm{DA}-6$ & Off-Gas Treatment & 0 & 1800 & 1800 & 2700 & $2,83.5$ \\
\hline $\mathrm{DA}-7$ & Prepare \& feed Lime & 600 & 0 & 01 & $0 !$ & 270 \\
\hline $\mathrm{DA}-8$ & Treat Liquid Waste & 0 & 600 & 01 & 9001 & 675 \\
\hline $\mathrm{DA}-9$ & Store \& Feed Binder & 1050 & $0 !$ & 01 & $0 !$ & 47.3 \\
\hline $\mathrm{DA}-10$ & Elec. Dist \& MCC & 1500 & $0 !$ & 0 & 0 & 675 \\
\hline $\mathrm{DA}-11$ & Heating, Ventilation \& Exhaust & & 2400 & & & 1,080 \\
\hline $\mathrm{DA}-12$ & Otber Equipment & 01 & 01 & 01 & $0 !$ & 0 \\
\hline & Total Cost & & & & & 9.947 \\
\hline & & Post Totals to & Table DA & Itcm & & 6.0 \\
\hline
\end{tabular}

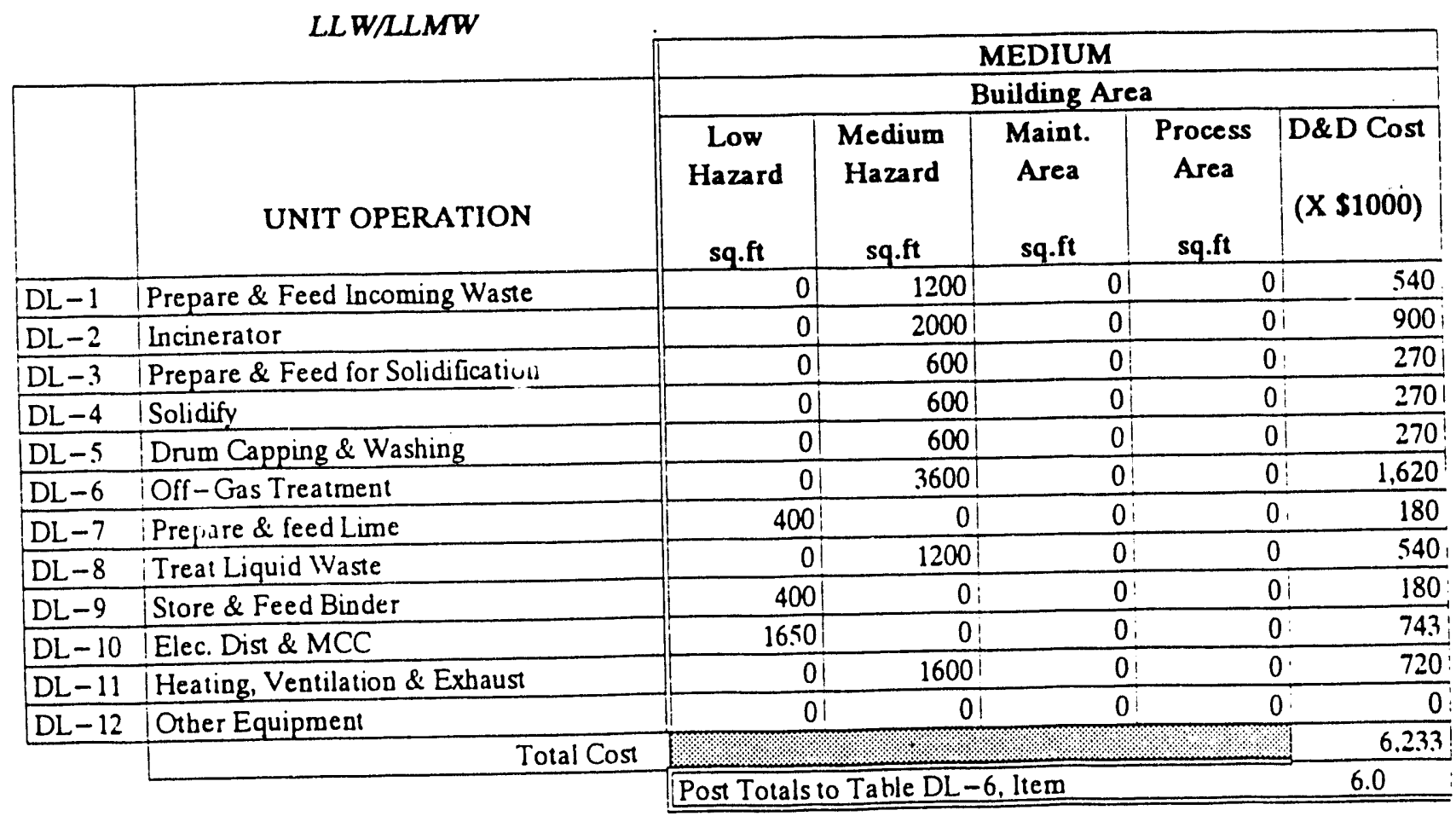




\section{Appendix B}

\section{Scenario Costing Worksheet}

B-1 
B-2 


\section{Appendix B}

\section{Scenario Costing Worksheet}

\section{B.1 SCENARIO COSTING STEPS}

\section{B.1.1 Step 1-Define Scenarios}

Step 1.1-Define waste sources and generator locations. Enter data in Table B-1 per the following instructions (use one table for each location):

a. Enter in the first row heading the location of the facility where the waste is generated or stored.

b. For each category of waste, enter the quantity (lbs) in the appropriate cell in the table. If input waste is in cubic feet or cubic meter, multiply by the appropriate density to get total waste quantity in lbs.

Step 1.2-Define types and location of treatment facilities and their input waste quantities. Use Table B-2 as a guide in selecting a treatment facility that is suitable for a given waste category. Enter data in Table B-3 per the following instructions (use one table for each location):

a. Enter in the table first row heading the location where the treatment facility is to be located.

b. Place a checkmark under the "Req'd" column in front of each required facility.

c. Enter input waste quantity from step 1-1 in front of the required facility and under the "input waste quantity" column.

d. If a facility is a stand-alone facility (i.e., it is not being augmented to an existing operational facility), select the appropriate front-end and back-end support facilities and enter input waste quantities in front of the required facilities under the "input waste quantity" column.

Step 1.3-Define types and location of storage facilities. Enter data Table B-4 per the following instructions (use one table for each location):

a. Enter in the table first row heading the location where the facility will be located.

b. Place a checkmark under the "Req'd" column in front of the required storage facility.

c. If a facility is a stand-alone facility (i.e., it is not being augmented to an existing operational facility), select the front-end/back-end support facility and place a checkmark under the "Req'd" column in front of the front-end/back-end support facility. 
Table B-1. Waste sources information for each location.

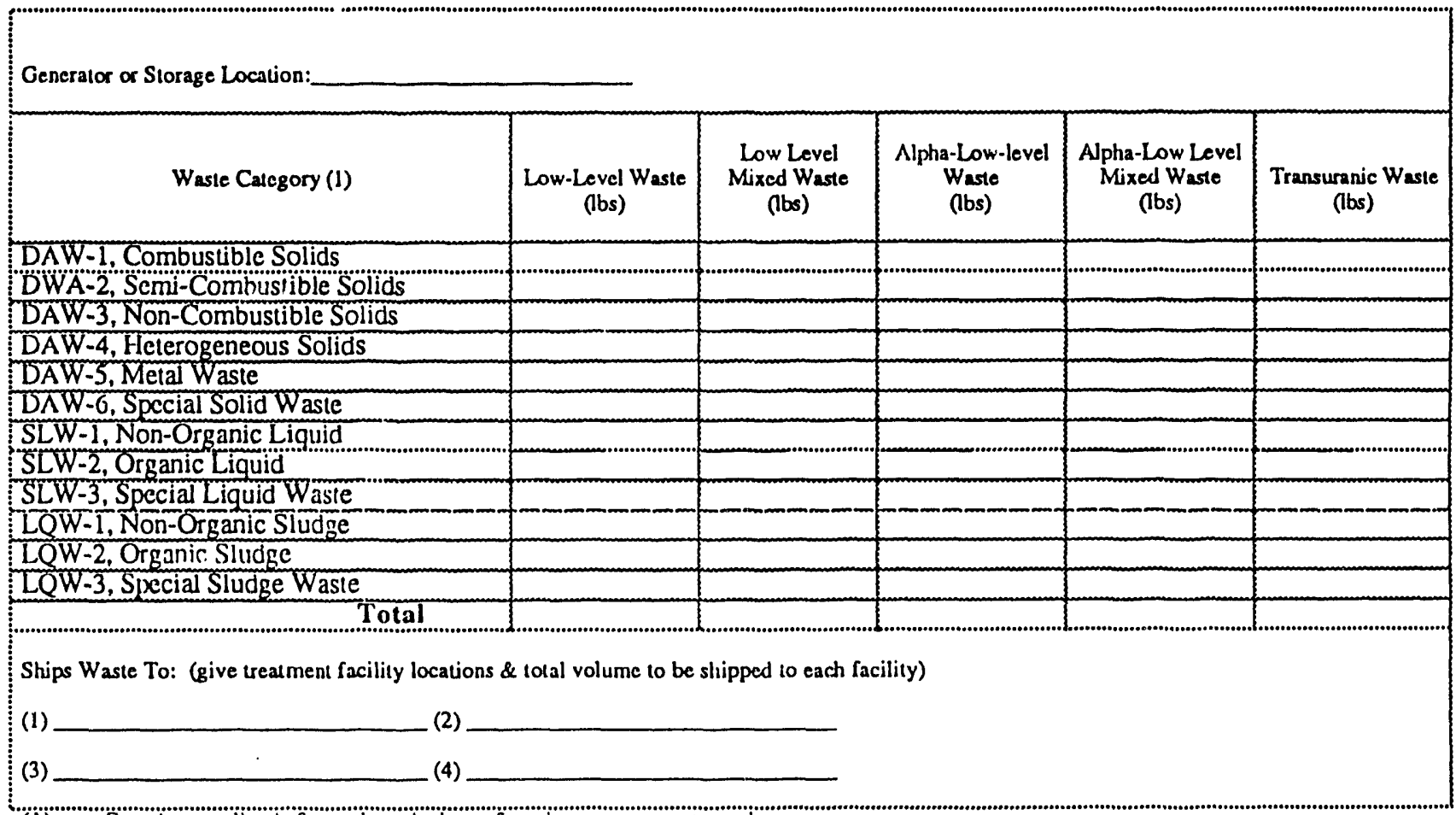

(i) See Appendix $A$ For a description of various waste categories.

Table B-2. Treatment facility selection guide.

\begin{tabular}{|c|c|c|c|c|c|c|c|c|c|c|c|c|}
\hline Treatnent Type & $\begin{array}{l}\text { DiilW-1 } \\
\text { Combust. } \\
\text { Solids }\end{array}$ & $\begin{array}{l}\text { DAW-2 } \\
\text { Semi- } \\
\text { Combust. } \\
\text { Solids }\end{array}$ & $\begin{array}{l}\text { DAW-3 } \\
\text { Non- } \\
\text { Combust. } \\
\text { Solids }\end{array}$ & $\begin{array}{l}\text { DAW-4 } \\
\text { Hetcrog- } \\
\text { encous } \\
\text { Solids }\end{array}$ & $\begin{array}{l}\text { DAW-5 } \\
\text { Metal } \\
\text { Waste }\end{array}$ & $\begin{array}{l}\text { DAW-6 } \\
\text { Special } \\
\text { Solid } \\
\text { Waste }\end{array}$ & $\begin{array}{l}\text { SLW-1 } \\
\text { Non- } \\
\text { Organic } \\
\text { Sludge }\end{array}$ & $\begin{array}{l}\text { SLW-2 } \\
\text { Organic } \\
\text { Sludge }\end{array}$ & $\begin{array}{l}\text { SLW-3 } \\
\text { Special } \\
\text { Sludge } \\
\text { Waste }\end{array}$ & $\begin{array}{l}\text { LQW-1 } \\
\text { Non- } \\
\text { Organic } \\
\text { Liquid }\end{array}$ & $\begin{array}{l}\text { LQW-2 } \\
\text { Organic } \\
\text { Liquid }\end{array}$ & $\begin{array}{l}\text { LQW-3 } \\
\text { Special } \\
\text { Lquid } \\
\text { Waste }\end{array}$ \\
\hline Incincration & (l) & (l) & NR & $\begin{array}{l}70 \% \text { of } \\
\text { lotal (3) }\end{array}$ & NR & NR & NR & (I) & $N R$ & NR & (1) & $N R$ \\
\hline Metal Melling & NR & NR & NR & $\begin{array}{l}8.5 \% \text { of } \\
\text { tolal (3) }\end{array}$ & (1) & NR & NR & NR & NR & NR & NR & NR \\
\hline $\begin{array}{l}\text { Shredder/ } \\
\text { Compaction }\end{array}$ & (2) & (2) & (2) & (2) & (2) & NR & NR & NR & NR & NR & NR & NR \\
\hline Solidification & NR & NR & (1) & $\begin{array}{l}20 \% \text { of } \\
\text { lotal (3) }\end{array}$ & $N R$ & $N R$ & (I) & (2) & NR & (1) & (2) & NR \\
\hline Vitrification & $N R$ & NR & (1) & $\begin{array}{l}20 \% \text { of } \\
\text { lotal (3) }\end{array}$ & NR & NR & (1) & NR & NR & (l) & NR & NR \\
\hline $\begin{array}{l}\text { Special } \\
\text { Trealment }\end{array}$ & NR & $N R$ & NR & $\begin{array}{l}1.5 \% \text { of } \\
\text { lotal (3) }\end{array}$ & NR & (1) & NR & NR & (1) & NR & NR & (1) \\
\hline
\end{tabular}

(1). Generally recommindal for both RCRA and non-RCRA waste (LLW/LLMW and alpha-LLW/L.LMW).

(2). Generally recommended for non-RCRA waste (LLW and alpha-LLW) only.

(3). This percentage breakcluwn is based on tl.e assumption used in this report. If available, the reader should use actual site specific data.

NR Generally not recominended for the given waste stream 
Table B-3. Treatment facilities information.

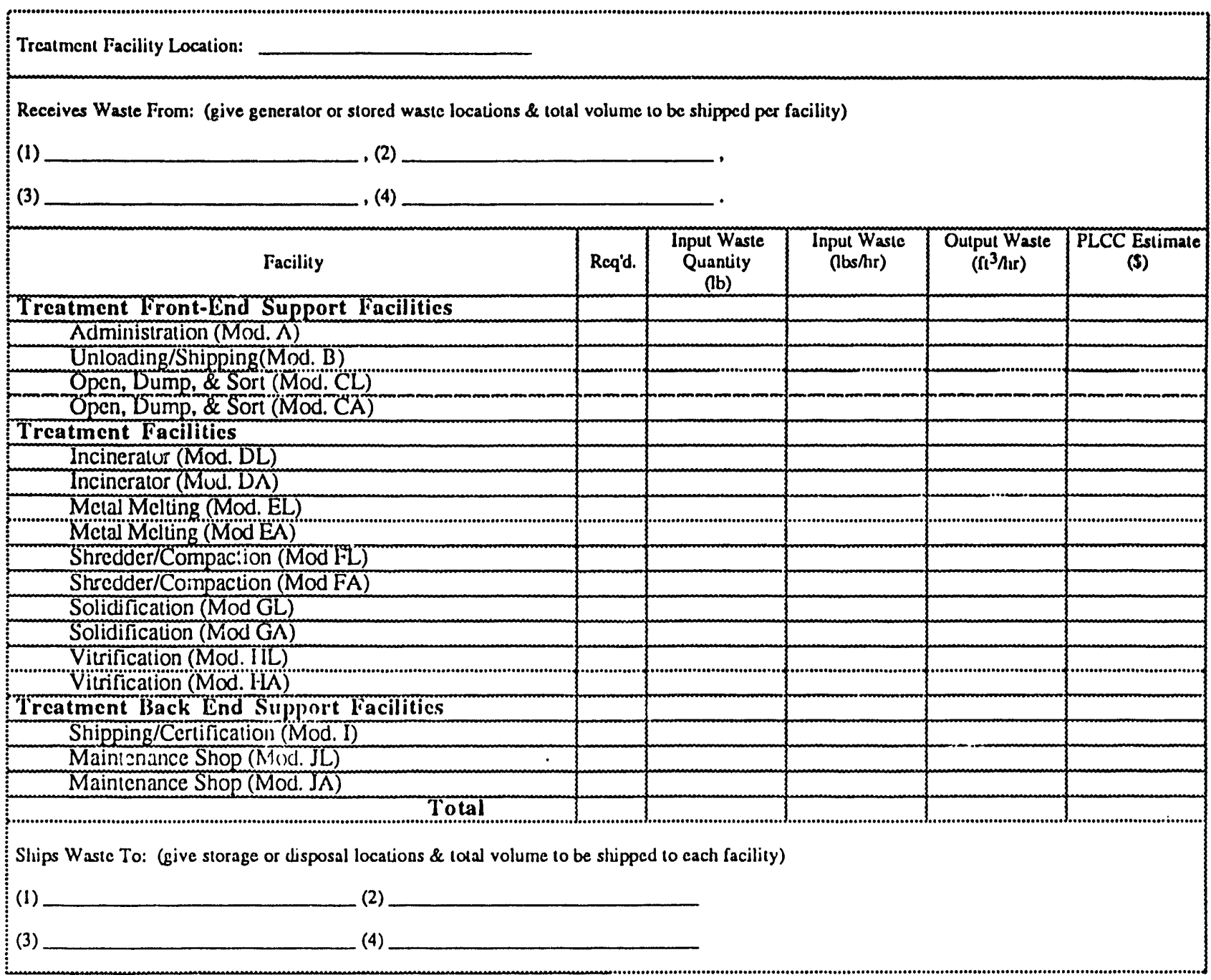


Table B-4. Storage facilities information.

\begin{tabular}{|c|c|c|c|c|}
\hline \multicolumn{5}{|l|}{ Storage Facility Location: } \\
\hline \multicolumn{5}{|c|}{ Receives Waste From: (give treatment facility locations \& total volume to be shipped per facility) } \\
\hline \multicolumn{5}{|l|}{ (1) } \\
\hline \multicolumn{5}{|l|}{ (3) } \\
\hline Facility & ikeq'd. & $\begin{array}{l}\text { Input Waste } \\
\left(\mathrm{ft}^{3} \mathrm{hr}\right)\end{array}$ & $\begin{array}{l}\text { Oulput Wastc } \\
\left(\left(n i^{3} / \mathrm{Mr}\right)\right.\end{array}$ & $\begin{array}{c}\text { PLCC Estimate } \\
(\$)\end{array}$ \\
\hline \multicolumn{5}{|l|}{ Storage Front-End/Back-End Support Facilitics } \\
\hline \multicolumn{5}{|l|}{ Admin./Onloading/Shipping(Mod. K) } \\
\hline \multicolumn{5}{|l|}{ Storage Tacilities } \\
\hline \multicolumn{5}{|l|}{ LLW Sturage (Mod.L) } \\
\hline \multicolumn{5}{|l|}{ Alpha-LLWWLLM STorage (Mod.M) } \\
\hline \multicolumn{5}{|l|}{ TKUW Slorage (Mod. M) } \\
\hline \multicolumn{5}{|l|}{ LLMW Storage (Mod N) } \\
\hline Total & & & & \\
\hline \multicolumn{5}{|c|}{ Ships Waste To: (give disposal locations \& tolal volume to be shipped to each facility) } \\
\hline
\end{tabular}

Step 1.4-Define types and location of disposal facilities. Enter data in Table B-5 per the following instructions (use one table for each location):

a. Enter in the table first row heading the place where the facility will be located.

b. Place a checkmark under the "Req'd" column in front of the required disposal facility.

c. If a facility is a stand-alone facility (i.e., it is not being augmented to an existing operational facility), select the front-end support facility and place a checkmark under the "Req'd" column in front of the front-end support facility.

\section{B.2.1 Step 2-Define Parameters}

Step 21-Calculate treatment facility input and output flow rates. For each treatment facility including all front-end and back-end support facilities, perform calculations and enter data in Table B-3 per the following instructions:

a. Enter in the blank space in the table second row heading the origin of the generated or stored waste that will be sent to the treatment facility and the total waste to be shipped from each origin. 
Table B-5. Disposal facilities information.

\begin{tabular}{|c|c|c|c|}
\hline \multicolumn{4}{|l|}{ Disposal Facility Location: } \\
\hline \multicolumn{4}{|c|}{$\begin{array}{l}\text { Receives Waste From: (give trintment or storage facility locations \& total voistne to be slipped per facility) } \\
\begin{array}{ll}\text { (1) } & \text { (2) } \\
\text { (3) } & \text { (4) }\end{array}\end{array}$} \\
\hline Facility & Reg'd. & $\begin{array}{c}\text { Input Waste } \\
\left(\left(\mathrm{l}^{3} \mathrm{hrr}\right)\right.\end{array}$ & PLCC Estimatc (\$) \\
\hline \multicolumn{4}{|l|}{ Disposal Front-End Support Facilitics } \\
\hline \multicolumn{4}{|l|}{ Admin $/$ Nnloading/Stipping(Mod. Ö) } \\
\hline \multicolumn{4}{|l|}{ Disposal lacilitics } \\
\hline Non-RCRA Enginecred Disposal(Mod. P) & & & \\
\hline RCRA Enginecred Disposal (Mad. Q) & & & \\
\hline Shallow Land Disposal (Mod. K) & & & \\
\hline Genlneic Disposal (Mod N) & & & \\
\hline (n) & & & \\
\hline
\end{tabular}

b. Divide each treatment facility input waste quantity (in lbs) by 80,640 hours to get input waste flow rate (in $\mathrm{lbs} / \mathrm{h}$ ). Enter this number in front of the selected facility under the designated column.

c. Multiply each treatment and back-end facilities input flow rates by the conversion factors given in Table 18-2 to obtain "output waste" flow rates (in $\mathrm{ft}^{3} / \mathrm{h}$ ). Enter this number in front of the selected treatment and back-end treatment facilities under the designated column. (Note: this step is not required for the front-end facilities.)

d. Enter in the blank space in the last row of the table the destination of the treated waste and the total waste to be shipped to each destination.

Step 2.2-Calculate storage facility input and output flow rates. For each storage facility including the front-end/back-end support facility, perform calculations and enter data in Table B-4 per the following instructions:

a. Enter in the blank space in the table second row heading the origin of the treated waste that will be sent to the storage facility and the total waste to be shipped from each origin.

b. Add the output flow rates of the treatment facilities that will be sending waste to the storage facility. Enter this number in front of the selected facilities under the "input waste" column.

c. Enter in the blank space in the last row of the table the destination of the stored waste and the total waste to be shipped to each destination.

Step 23-Calculated Disposal facility input flow rates. For each disposal facility includiing the front-end support facility, perform calculations and enter data in Table B-5 per the following instructions: 
a. Enter in the blank space in the table second row heading of the table the origin of the treated or stored waste that will be sent to the disposal facility and the total waste to be shipped from each origin.

b. Add the output flow rates of the treatment and storage facilities that will be sending waste to the disposal facility. Enter this number in front of the selected facilities under the "input waste" column.

Step 2.4-Calculate transportation distances. Enter data in Table B-6 per the following instructions (use one matrix for each scenario):

a. For each treatment facility enter the location of the generator or storage facility sending waste for treatment and the total volume of the incoming waste. Enter the distance (in miles) between the generator or storage and treatment facilities.

b. For each storage facility enter the location of the treatment facility sending waste for storage and the total volume of the incoming waste. Enter the distance (in miles) between the treatment and storage facilities.

c. For each disposal facility enter the location of the treatment or storage facility sending waste for disposal and the total volume of the incoming waste. Enter the distance (in miles) between the treatment or storage and disposal facilities.

Table B-6. Transportation information for each scenario.

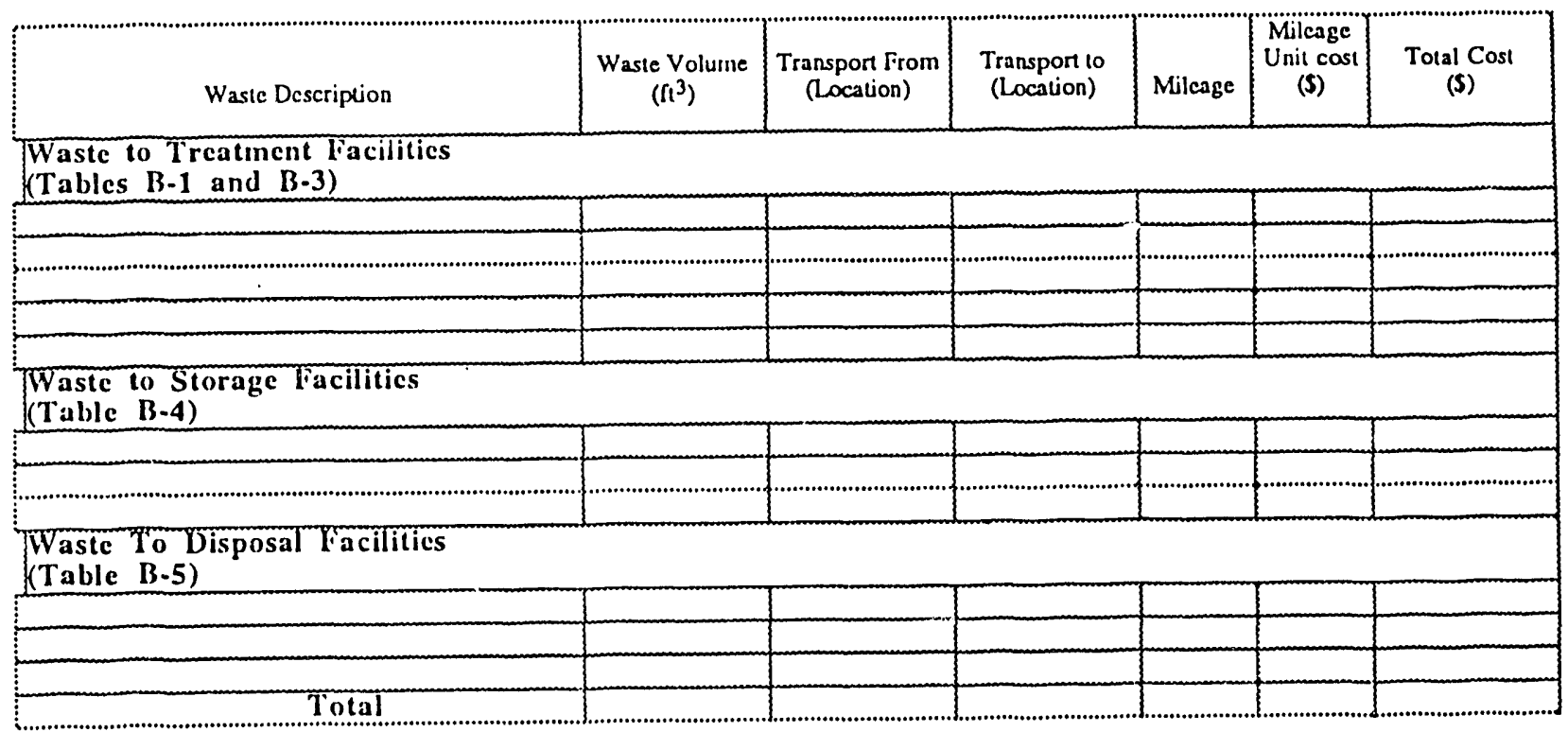




\section{B.3.1 Step 3-Develop Treatment PLCC Estimates}

For each of the treatment facilities identified in Table B-3 refer to an appropriate cost histogram in Sections 2 to 11 of the report. Obtain PLCC estimate from this histogram by selecting one of the cost modules which is the closest to the required capacity. Enter this cost in Table B-3 under the designated column in front of the given treatment facility.

\section{B.4.1 Step 4-Develop Storage PLCC Estimates}

Fore each storage facility identified in Table B-4, refer to an appropriate cost histogram in Sections 12 and 13 of the report. Obtain a PLCC estimate from this histogram by selecting one of the cost modules closest to the required capacity. Enter this cost in Table B-4 under the designated column in front of the given storage facility.

\section{B.5.1 Step 5-Develop Disposal PLCC Estimates}

For each disposal facility identified in Table B-5, refer to an appropriate cost histogram in Sections 14 through 17 of the report. Obtain a PLCC estimate from this histogram by selecting one of the cost modules closest to the required capacity. Enter this cost in Table B-5 under the designated column in front of the given disposal facility.

\section{B.6.1 Step 6-Develop Transportation Cost Estimates}

In Table B-6, multiply volume of the waste to be shipped by the factors given in Section 18.5.6. Enter total cost in the designated column in Table B-6.

\section{B.7.1 Step 7-Total PLCC Estimates}

Enter total costs from Tables B-3, B-4, B-5 and B-6 in Table B-7. Add the totals to obtain total cost for the scenario.

Table B-7. Total scenario PLCC estimate.

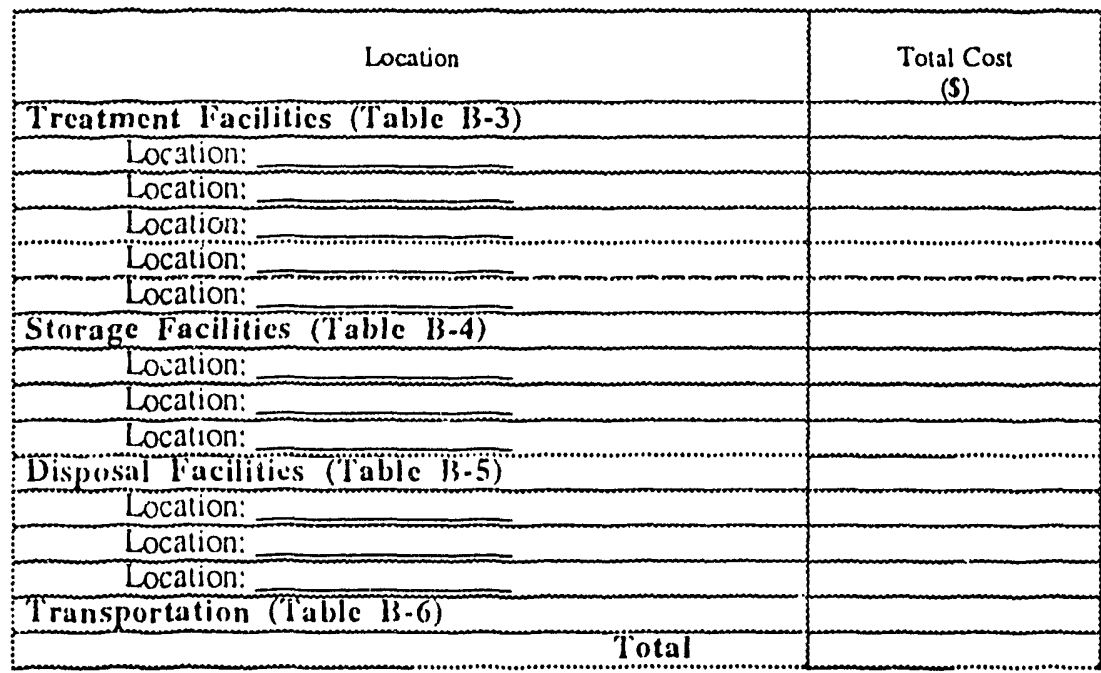



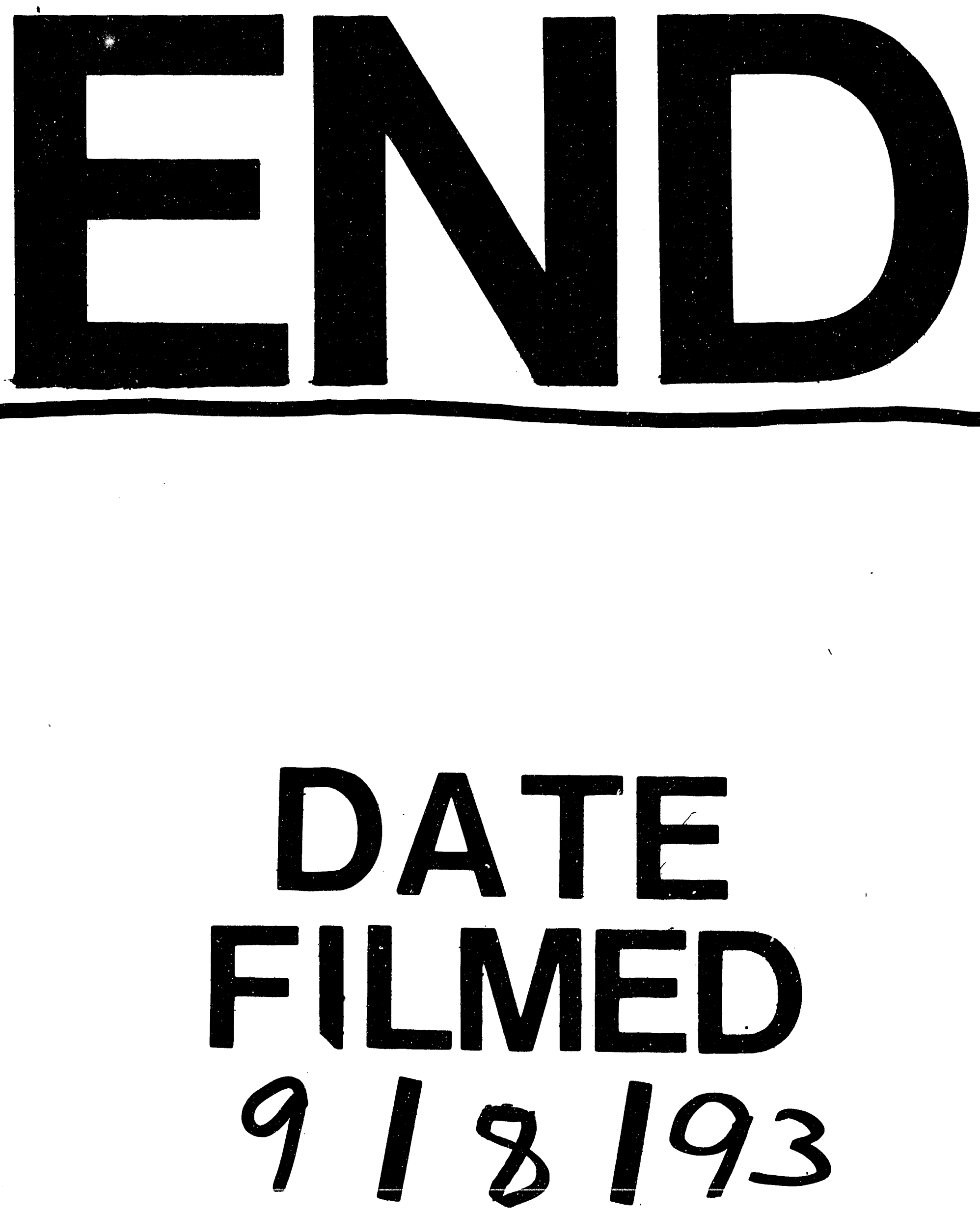
